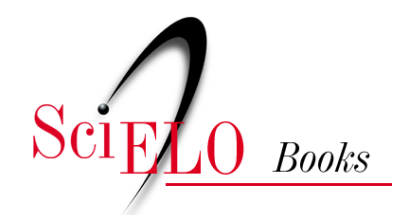

\title{
Ética e paradigmas na psicologia social
}

\author{
Kátia Simone Ploner \\ Lísia Regina Ferreira Michels \\ Luciane Maria Schlindwein \\ Pedrinho A. Guareschi \\ orgs.
}

PLONER, KS., et al., org. Ética e paradigmas na psicologia social [online]. Rio de Janeiro: Centro Edelstein de Pesquisas Sociais, 2008. 313 p. ISBN: 978-85-99662-85-4. Available from SciELO Books <http://books.scielo.org $>$.

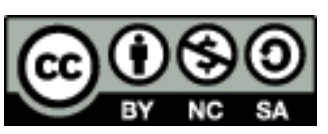

All the contents of this chapter, except where otherwise noted, is licensed under a Creative Commons Attribution-Non Commercial-ShareAlike 3.0 Unported.

Todo o conteúdo deste capítulo, exceto quando houver ressalva, é publicado sob a licença Creative Commons Atribuição Uso Não Comercial - Partilha nos Mesmos Termos 3.0 Não adaptada.

Todo el contenido de este capítulo, excepto donde se indique lo contrario, está bajo licencia de la licencia Creative Commons Reconocimento-NoComercial-CompartirIgual 3.0 Unported. 
Kátia Simone Ploner

Lísia Regina Ferreira Michels

Luciane Maria Schlindwein

Pedrinho A. Guareschi

Organizadores

\section{Ética e Paradigmas na Psicologia Social}

Centro Edelstein de Pesquisas Sociais

www.centroedelstein.org.br

Rua Visconde de Pirajá, 330/1205

Ipanema - Rio de Janeiro - RJ

CEP: 22410-000. Brasil

Contato: bvce@centroedelstein.org.br

Rio de Janeiro

2008 


\section{SUMÁRIO}

Prefácio

Neusa Maria de Fátima Guareschi

\section{Apresentação}

Kátia Ploner, Lísia Michels, Luciane Schlindwei, Pedrinho A. Guareschi

\section{Ética e paradigmas na psicologia social}

Ética e paradigmas

Pedrinho A. Guareschi

Ética e paradigmas: desafios da psicologia social contemporânea Rosane Neves da Silva

Reflexões sobre pesquisa em psicologia, método(s) e "alguma" ética....46 Andréa Vieira Zanella

Identidade, subjetividade, alteridade e ética Neuza Maria de Fátima Guareschi

Da subjetividade sob sofrimento narcísico numa cultura da banalidade do mal: abordagem ético-política do sofrimento humano... Angela Maria Pires Caniato

A psicologia na construção da igualdade Marlene Neves Strey

Práxis e ética na psicologia social comunitária: possibilidades de transformação social na vida cotidiana

Maria de Fatima Quintal de Freitas

\section{Psicologia e educação}

A inclusão da pessoa com necessidades especiais na universidade: na perspectiva dos professores
Dialogando com o diferente: a convivência e a pluralidade cultural.... 126 Ana Pagamunici

Universidade da terceira idade: reflexões sobre preconceitos e projetos Daiane Manerich, Juliana Vieira de Araújo Sandri e Biaze Manger Knoll

Representação social do bom aluno: implicações éticas na educação.. 152 Maria Helena Cordeiro, Anelize Donaduzzi e Sabrina Maria Schlindwein

Discurso e significação dos professores do curso pedagogia sobre o

Exame Naciona 163

Luciane Maria Schlindwein, Cláudia Renate Ferreira e Claudia Maria Petri

Educação e saúde: considerações a respeito da atuação interdisciplinar em uma comunidade escolar 178

Leia Viviane Fontoura, Salete Galvan, Adir Luiz Stiz e Deyse Ferreira

\section{Psicologia, saúde e trabalho}

Capacitação em saúde mental com técnicos do Programa Saúde da Família do município de Forquilhinha ...

Dipaula Minotto da Silva, Eliziane Martins Bernardo e Edelu Kawahala

Demandas e ofertas da psicologia do trabalho hoje.

Denise Macedo Ziliotto

Programa de sensibilização para a escolha profissional

Maria Clara de Jonas Bastos, Cláudia S. S. dos S. Schiessl e Everton Cordeiro Mazzoleni

A reorientação ocupacional/profissional após a mastectomia: uma nova proposta de inserção social.

Maria Clara de Jonas Bastos e Josiane Aparecida F. de A. Prado

É hora do espetáculo da perversidade: o aprisionamento da subjetividade dentro dos realities shows .................................................................. 236

Regina P. Christofolli Abeche, Ângela Caniato e Lara Hauser Santos

Lísia Regina Ferreira Michels e Gabriela Andrea Díaz 
A ética na escuta psicológica: o atendimento inicial e a fila de espera. 253 Carmen L. O. O. Moré, Aline Rössel, Naiane Carvalho Wendt e Vanessa Silva Cardoso

\section{Psicologia e relações de gênero}

A constituição do sujeito excluído catador de material reciclável e a construção da sua cidadania.....

Daiani Barboza

Constituição do sujeito e relações de gênero em um contexto de ensinar e aprender......

Silvia Zanatta Da Ros e Sandra Iris Sobrera Abella

Questões de gênero em grupos de terceira idade

Katia Simone Ploner, Almir Sais e Marlene Neves Strey

\section{PREFÁCIO}

\section{Neusa Maria de Fátima Guareschi} Presidente da ABRAPSO

É com certa frequência que em discussões de grupos, acadêmicas ou não, escutamos as pessoas se referindo a determinados temas, situações ou episódios como estando estes direta ou indiretamente implicados com questões éticas ou de paradigmas. Estamos vivendo tal momento, na sociedade contemporânea, em que, talvez, nunca se tenha falado tanto sobre estes dois conceitos. Dentre o enorme número de referências que se fazem a esses conceitos, encontramos, geralmente, sentidos que lhes conferem um caráter universal e consensual.

Em relação a paradigmas, podemos destacar pelo menos dois aspectos que, logicamente, estão relacionados entre si e, portanto, um não exclui outro: o primeiro aspecto remete às concepções hegemônicas e tradicionais da ciência como quando alguém fala: "isto é uma questão de paradigmas", ou "estou falando de outro paradigma”. Isso parece querer dizer que o que está em discussão já é algo definido por um conhecimento, por um lugar, por um método, pela ciência, ou seja, possui uma verdade. Como diz Bujes (2002), recebe um "selo de qualidade"; ou como fala Fischer (2002), "uma frase de efeito". O segundo aspecto, refere-se, exatamente, àquilo que podemos, ou não, definir como o que é um paradigma. Ou seja, como se paradigma pudesse ter um conceito que o abarcasse em sua totalidade. Isto seria como que supor que esse conceito tivesse uma fronteira estabelecida, ou uma finitude. Como coloca VEIGANETO (2002), "isso significaria diminuir-lhe a polissemia, fixar-lhe o(s) sentido(s)" o que, em outras palavras, determinaria o que pode ser alado, pensado ou localizado como sendo paradigma.

Thomas Kuhn (1976) em sua já clássica obra A Estrutura das Revoluções Científicas vem esclarecer esse conceito quando discute que um paradigma seria constituído a partir de "crenças em modelos particulares" (p.28), tendo como parâmetro os diferentes valores entre os grupos sociais e comunidades científicas, revolucionando assim, as interpretações 
generalizáveis, os métodos universais e as definições consensuais que caracterizam o que a modernidade designou como sendo conhecimento científico. Portanto, a visão que Kuhn nos apresentou sobre paradigmas leva - nos a supor que os paradigmas são construídos pelas formas históricas, sociais e culturais de vida as sociedades.

Diante dessas questões, podemos começar a questionar então, não o que é um paradigma, mas sim, o que um paradigma nos indica. E neste momento que a discussão sobre paradigmas toma sua máxima relevância não só para a Psicologia ou Psicologia Social mas para todo o campo das Ciências Sociais e Humanas. Assim, podemos dizer quê paradigma nos indica os modos particulares de vida das pessoas. Mais do que isso: o paradigma nos traz possibilidades de entendermos as formas e mecanismos que as pessoas utilizam para se inserir no mundo, estar no mundo ou de pensar e significar suas práticas ou a si próprias nele. Temos, desta forma, de enfatizar o caráter contextual dos paradigmas conferido pela cultura, pelo social e pela história sempre localizados temporal e espacialmente. Da mesma forma, temos de buscar os diferentes sentidos produzidos através da linguagem, construtora dos sujeitos e visualizar as formas de circulação de poder, interessando-nos pelos modos singulares e descontínuos de subjetivação.

É possível dizer que, na discussão que fizemos até aqui, não nos desprendemos nem nos afastamos daquilo que pensamos sobre ética. Paralelo ao que propusemos sobre paradigmas, em relação às concepções sobre ética também podemos pensar, muitas vezes, ser este conceito tomado com um caráter universal, como se fosse o mesmo para todos, ou ainda, como se tivesse sentidos fixos. Limitar a compreensão do que é ética, seria não só produzir um reducionismo sobre um conceito mas, principalmente, entender o sujeito dentro de uma concepção essencialista, negando suas diferenças, sua história e sua cultura, ou seja, negar exatamente as condições daquilo que o faz ser humano.

Considerando que a filosofia sempre tratou a moral como sendo o objeto de estudo da ética, vamos nos deparar com algo a respeito do qual na sociedade contemporânea, tem se tornado cada vez mais difícil chegarmos próximos de entendimento, ou consenso, tamanha sua complexidade. Estamos nos referindo à moral como o conjunto dos costumes, tradições que se estabeleceram como aceitáveis e corretas dentro de determinados grupos. E entendemos a ética como uma reflexão crítica dessa moral.
Foucault (1998) nos apresenta uma discussão sobre moral relacionando-a com três significado diferentes: o significado do código, o significado dos comportamentos e o significado do constituir um si mesmo, constituição de um sujeito moral. Para Foucault, a moral do código diz respeito aos valores, normas e regras prescrito pelas instituições na sociedade. A moral dos comportamentos relaciona-se a, tipo de ações e atitudes propostas pela sociedade e que esta espera ser apresentada nos comportamentos. $\mathrm{O}$ terceiro significado, a constituição de um sujeito moral, implica em considerar a diversidade entre os seres humanos na forma de ser e estar no mundo, ou de constituírem-se sujeitos pela diferença.

A partir desta discussão proposta por Foucault (1998), Spink (2000) trata os primeiros dois significados de moral colocados por este autor como moral prescritiva ou a ética prescritiva. Já o terceiro significado é denominado por Spink como a ética dialógica. A primeira acepção é fundamentada em um código efetuado através da prescrição de comportamentos pelas instituições sociais. A segunda é pautada na interação, ou na interanimação dialógica, ou seja, o processo que incorpora os diferentes sentidos e endereçamentos que os envolve nas relações sociais (SPINK, 2003). Já o que caracteriza a perspectiva da ética dialógica é deixar que todas as vozes apareçam no discurso, isto é, que as relações sociais possam ser construídas pelas diferenças, que os sujeitos se constituam na relação com o outro, com a alteridade e não por relações sociais hegemônicas.

Como essas questões sobre ética podem ser problematizadas na Psicologia ou na Psicologia Social? Em um primeiro momento, devemos questionar o essencialismo e o caráter universal na concepção de sujeito. Como se todos tivessem as mesmas chances ou oportunidades e como se todos fossem iguais, ou seja, como se entre homens e mulheres, negros e brancos, não existisse nenhuma diferença social, cultural, econômica, racial ou sexual implicada na constituição da moralidade e da ética do sujeito.

Se pensarmos como a Psicologia toma, trabalha ou se insere em suas práticas, percebemos que, tradicionalmente existe uma tendência a tomar como natural a classificação dos comportamentos dos sujeitos entre aquilo que é da norma, do hegemônico e o que não faz parte daquilo que é considerado comportamento padrão. Essas questões são dicotomizadas a partir de discursos que se fundamentam em técnicas, métodos, conceitos e 
teorias tidas como comprovadas cientificamente que, portanto, podem ser generalizadas e aceitas de forma universal. Tudo isso em nome de determinados paradigmas e preceitos éticos.

Como pode o sujeito ser compreendido unicamente de uma forma universal? Separado de sua cultura, de sua história e de sua sociedade? Como podemos pensar o psiquismo sem considerarmos os modos singulares dos sujeitos se inserirem na cultura? Essas perguntas devem persistir dentro da Psicologia e da Psicologia Social para que possamos trazê-las para a lógica de concepção de sujeito constituído pelas diferenças. Pensar os sujeitos pelas diferenças passa por questões políticas como a organização de políticas de geração de renda, de gestão de pessoal, de construção de identidades através dos marcadores de gênero, raça e diversidade sexual, da produção de estratégias para a construção de uma clínica política e de outros dispositivos para o atendimento ao sofrimento psíquico. No pressuposto de saúde, educação, moradia, trabalho e segurança, direitos básicos para o desenvolvimento da cidadania e democracia, deve ser considerado as diferenças, a pluralidade.

Os sentidos que a expressão "saúde mental” podem adquirir são muitos. Dentre eles, está o de uma face normativa, prescritiva, que faz referência a uma espécie de conjunto de atributos para uma pessoa ser considerada saudável. A Psicologia tem, assim, como desafio para articular as questões de paradigmas e da ética em suas práticas, de forma incisiva, perguntar-se que concepção de sujeito e de sociedade é pressuposta como pano de fundo para estas práticas psicológicas. Seria a prática da homogeneização para "adaptação"? Mas, adaptar a que? Tornar uma pessoa "igual a maioria" ou apta a fazer o "que todo mundo faz"? Esta não é uma resposta séria, nem refletida. A temática sobre paradigmas e ética é complexa, merecendo como resposta uma abordagem também complexa que, no mínimo, consiga ser problematizadora de questões do contemporâneo que envolvem as práticas psicológicas sobre educação, trabalho, comunicação, doença, saúde mental, infância, adolescência, identidades, violência, a exemplo de como foram discutidas no encontro da Regional Sul da ABRAPSO e que são tratadas neste livro.

A Psicologia Social deve encarar sua produção de conhecimentos como difícil, pois sua pluralidade de campos de saber, de abordagens e de práticas é tão vasta que, talvez, nunca possamos e nem devamos almejar uma "identidade" para ela. Esta é a questão: entendermos que um trabalho de construção plural e promotor da inclusão social e dos direitos fundamentais do ser humano passa pelo reconhecimento das diferenças. Não se trata da busca de hegemonia de paradigmas. Eis um dos nossos desafios éticos no trabalho de formação e, acima de tudo, do campo de intervenção e construção de conhecimento em Psicologia Social.

\section{Referências}

BUJES, Maria I. E. (2002). Descaminhos. In: COSTA, Marisa Vorraber. Caminhos Investigativos: outros modos de pensar e fazer pesquisa em educação. Rio de Janeiro, DP\&A.

FISCHER, Rosa M. B. (2002). Verdades em Suspenso: Foucault e os perigos a enfrentar. In: COSTA, Marisa Vorraber. Caminhos Investigativos: outros modos de pensar e fazer pesquisa em educação. Rio de Janeiro, DP\&A.

FOUCAULT, Michel. (1998). O Uso dos Prazeres. Rio de Janeiro: Graal.

KUHN, Thomas (1976). A Estrutura das Revoluções Científicas. São Paulo: Perspectiva.

SPINK, Mary Jane (2000). A Ética na Pesquisa Social: da perspectiva prescritiva à interanimação dialógica. Revista PSICO. Vol. 31. n. 1. Porto Alegre. jan/jul 2000. Semestral.

(2003). A Produção de Sentidos como Linguagem em Ação. Coleção: temas da Contemporaneidade em Psicologia Social. v.1. Porto Alegre: EDIPUCRS, 2003.

VEIGA-NETO, Alfredo (2002). Paradigmas? Cuidado com eles!. In: COSTA, Marisa Vorraber. Caminhos Investigativos: outros modos de pensar e fazer pesquisa em educação. Rio de Janeiro, DP\&A, 2002 . 


\section{APRESENTAÇÃo}

A Associação Brasileira de Psicologia Social (ABRAPSO) vem afirmando seu compromisso com área da Psicologia Social, constituindo um espaço de produção e divulgação científica que tem se destacado no cenário nacional. Para contribuir com a produção do conhecimento nesta área, foi realizado em novembro de 2002, o IX Encontro da Regional Sul da ABRAPSO, sediado na Universidade do Vale do Itajaí (UNIVALI), em Itajaí - a Santa Catarina com o tema Ética e Paradigmas da Psicologia Social. O referido evento reuniu estudantes e profissionais da Psicologia e áreas afins, com saberes e histórias diferenciadas. Cumprindo com um dos objetivos da comunidade científica da ABRAPSO, este livro sintetiza a busca de aprimorar e expandir as discussões realizadas neste encontro.

O processo de construção iniciou com convite aos palestrantes das mesas e aos autores dos trabalhos selecionados como comunicação oral no sentido de aprofundar sobre a temática abordada no evento. Para nossa satisfação, tivemos uma grande receptividade e colaboração de estudiosos na área, que contribuíram para ampliação de temas e de atuação da Psicologia Social através de seus artigos.

Abrindo este livro, o texto denominado Ética e Paradigmas, de Pedrinho A. Guareschi, aborda uma questão instigante no âmbito da Psicologia Social. Para o autor é possível identificar dois grandes paradigmas que fundamentam as exigências éticas, ou os valores éticos na literatura: o da lei natural e o da lei positiva. Além destas duas vertentes, Guareschi acresce um terceiro olhar, que traz novas considerações para a discussão da problemática da ética: a ética tomada como instância crítica.

Rosane Neves da Silva apresenta o artigo denominado Ética $e$ Paradigmas: desafios da psicologia social contemporânea, no qual explora inicialmente, a noção de paradigma. Para a autora, a palavra paradigma precisa ser considerada em diferentes dimensões, a saber: a dimensão epistemológica (como conhecemos), a dimensão ontológica (o que é isso a se conhecido), a dimensão metodológica (que ferramentas utilizamos nesta investigação) e a dimensão ética (que valores conduzem nossas estratégias de produção do conhecimento). De acordo com o texto, o paradigma, enquanto estratégia de produção de conhecimento, tem uma função política, uma vez que estas diferentes dimensões expressam um determinado processo de subjetivação.

O texto Reflexões sobre pesquisa em psicologia, método(s) e 'alguma' ética, de autoria de Andréa Vieira Zanella, contextualiza as diferentes vertentes metodológicas que veem sendo adotadas nas pesquisas nas Ciências Humanas, especialmente, no campo da Psicologia. Para a autora, para além de uma discussão sobre a pertinência de metodologias, mais qualitativas ou mais quantitativas, é fundamental que os pesquisadores relevem a diversidade e a diferença presentes na sociedade atual e, mais que isso, reafirmem o compromisso de relacionar ética e ciência.

Neuza Maria de Fátima Guareschi aborda a temática Identidade, subjetividade, alteridade e ética partindo de uma virada cultural nos paradigmas das ciências sociais e humanas, tendo a cultura como constitutiva da vida social das políticas de identidade. Cultura é entendida como forma de vida, na qual inclui ideias, linguagem, práticas, instituições e instâncias de poder, tendo Foucault como referencial básico.

No decorrer do capítulo Da subjetividade sob sofrimento narcísico numa cultura de banalidade do mal, de Ângela Caniato, há uma reflexão, pautada na psicanálise, sobre a tensão dialética entre a subjetividade e a cultura na contemporaneidade, que apreende a violência de modo perverso. Expõe que o sofrimento psicossocial estrutura-se como impotência subjetiva, apatia e conformismo, questionando as práticas "psi" deste contexto.

Marlene Neves Strey, no artigo A psicologia na construção da igualdade discute o papel da Psicologia na busca da transformação social em direção a uma verdadeira igualdade de oportunidades, considerando fundamental a reflexão crítica e a prática ética. Discute que tipo de profissional, de intervenções e discussão ética as universidades estão incentivando e em que direção aparenta ir: reforçar as desigualdades ou lutar para superá-las?

O artigo Práxis e Ética na Psicologia Social Comunitária: possibilidades transformação social na vida cotidiana, apresentado pela Dra. Maria de Fátima Quintal de Freitas propõem-se a discutir sobre Ética e Paradigmas na relação com a prática dos profissionais de psicologia, considerando três dimensões a saber: ontológica, epistemológica e a 
dimensão da práxis. Para tanto, a autora apresenta uma reflexão crítica sobre os avanços obtidos e as dificuldades enfrentadas pela Psicologia Social Comunitária, por sua vez: comprometida com a construção de relações cotidianas mais justas e dignas.

$\mathrm{O}$ artigo seguinte, intitulado $A$ inclusão da pessoa com necessidades especiais na universidade, perspectiva dos professores, de autoria de Lísia Regina Ferreira Michels e Gabriela Andrea Díaz, é o resultado de uma investigação que busca evidenciar que tipo de relações se operam tendentes à inclusão/exclusão de alunos na universidade. As análises apresentadas no texto apontam as dificuldades vivenciadas pelos docentes, as estratégias utilizadas para a inclusão e o preconceito diante dos alunos com necessidades especiais Nesta perspectiva, as autoras sugerem que a educação inclusiva seja inserida na formação de professores.

Abordando a temática da identidade e alteridade, Ana Pagamunici oferece o artigo Dialogando com o diferente: a convivência e a pluralidade cultural. Ela discute como as relações com o "outro", com o diferente, faz com que nos reconheçamos e nos permita identificar as divergências, as diferenças Segundo a autora, do modo como estão se dando as relações, no contexto cultural em que vivemos, não precisamos mais pensar sobre o novo, fazendo com que não entremos em relação e não nos diferenciamos do mundo.

Os autores Kátia Simone Ploner, Daiane Manerich, Juliana Vieira de Araújo Sandri, Biaze Manger Knoll no artigo Universidade da Terceira Idade reflexões sobre preconceitos e projetos, abordam estereótipos envolvidos no retorno à universidade no período da aposentadoria e da velhice. Apresenta um programa de universidade da terceira idade realizado no sul do país e sua organização, discutindo princípios éticos e paradigmas envolvidos neste.

O texto Representação social do bom aluno: implicações éticas na educação é resultado de uma pesquisa que vem investigando as representações que os professores possuem acerca da educação de seus alunos. As autoras Maria Helena Cordeiro, Anelize Donaduzzi e Sabrina Maria Schlindwein analisam os professores na dinâmica social, cultural, econômica, histórica, educacional e afetiva que compõem as suas representações. As autoras consideram que é a partir destas representações que as professoras de ensino fundamental constroem suas expectativas sobre o futuro de seus alunos na escola.

O texto Discurso e significação dos professores do curso pedagogia sobre o exame nacional de curso, apresentado por Luciane Maria Schlindwein, Cláudia Renate Ferreira e Claudia Maria Petri traz resultados de uma pesquisa que investiga o impacto do ENC em um curso de Pedagogia. A palavra se constitui em ato, em campos discursivos, os professores que falam transformam a sua própria fala ao falar, constituindo tramas de significados diversos.

$\mathrm{O}$ artigo Educação e Saúde: considerações a respeito da atuação Interdisciplinar em uma comunidade escolar, apresentado pelos autores Leia Viviane Fontoura, Salete Galvan, Adir Luiz Stiz e Deyse Ferreira, apresenta os resultados de um projeto de extensão universitária, desenvolvido por uma equipe interdisciplinar da Universidade do Vale do Itajaí, numa comunidade escolar do município de Itajaí (SC). Partindo do referencial teórico proposto pela abordagem histórico-cultural, os autores demonstram o caminho percorrido nos últimos três anos, que possibilitou a transição do paradigma assistencial na concepção de saúde do escolar para a construção de uma práxis pela promoção de saúde.

Para fomentar reflexões sobre saúde mental coletiva e à relação técnico-usuário, proporcionar reflexões referentes à concepção de saúde/doença mental, rótulos e preconceitos é que os autores Dipaula Minotto da Silva, Eliziane Martins Bernardo, Edelu Kawahala se propuseram a escrever o artigo Capacitação em saúde mental com técnicos do programa saúde da família do município de Forquilhinha. A discussão está pautada no conceito de saúde de forma ampla, na descentralização do sistema de saúde, promoção de saúde e integração dos profissionais da saúde com a comunidade, procurando dignificar os sistemas de atendimento aos usuários.

Abordar criticamente práticas da psicologia comprometida com a lógica empresarial de eficácia - em que o indivíduo é tratado como recurso e não enquanto sujeito - é o eixo norteador do capítulo Demandas $e$ ofertas da Psicologia do trabalho hoje. Além disso, Denise Macedo Ziliotto aponta encaminhamentos e possibilidades para esta área. 
O artigo Programa de sensibilização para a escolha profissional, de Maria Clara de Jonas Bastos, Cláudia Silva Schead dos Santos Schiessl e Everton Cordeiro Mazzoleni, apresenta a estrutura e os resultados de um programa que utiliza-se de diversas técnicas, que vão desde dinâmicas de grupo, estórias em quadrinhos e apresentações com fantoches buscando facilitar que os alunos de escolas públicas desenvolvam pesquisas sobre as diversas profissões, visitas às universidades e escolas técnicas, bem como outras ocupações práticas que existem (pedreiro, carpinteiro, vendedor, etc.).

A seguir, Maria Clara de Jonas Bastos e Josiane Aparecida Ferrari de Almeida, no artigo A reorientação ocupacional/profissional após a mastectomia: uma proposta de inserção social, apresentam o resultado de uma investigação que busca compreender os novos sentidos na vida da mulher após a mastectomia. Neste sentido, o texto evidencia que novos significados e identificações no cotidiano da mulher, são refletidos na sua inserção profissional.

Em É hora do espetáculo da perversidade: o aprisionamento da subjetividade dentro dos reality shows é evidenciado um mecanismo da industria cultural midiática que promove a padronização das subjetividades: o reality show. As autoras Regina Perez Christofolli Abeche, Ângela Caniato e Lara Hauser Santos exploram os valores perversos que regem o cotidiano da vida dos participantes: confinamento, vigilância, exclusão, privação, fama, dinheiro, sorte, culto ao herói, salve-se quem puder, etc. Analisam estas questões sob enfoque psicanalítico, explicitando a ética que perpassa os atuam modelos identificatórios.

$\mathrm{O}$ artigo A ética na escuta psicológica: o atendimento inicial e a fila de espera apresenta uma contribuição à reflexão ética em torno dos modelos de intervenção utilizados em contexto de atuação. As autoras Carmen L.O.O. Moré, Aline Rössel, Naiane Carvalho Wendt e Vanessa Silva Cardoso analisaram vinte e seis casos durante noves meses, junto ao Serviço de Atendimento Psicológico da Universidade Federal de Santa Catarina.

Daiani Barboza, no texto A constituição do sujeito excluído catador de material reciclável e a construção da sua cidadania, apresenta uma análise da constituição do sujeito excluído, focando os aspectos do movimento potência, impotência na constituição da cidadania destes sujeitos. Para a autora, estes estudos podem contribuir para a construção de uma prática psicológica emancipatória, pautada na ética e na solidariedade.

$\mathrm{O}$ artigo Constituição do sujeito e relações de gênero em um contexto de ensinar e aprender, de autoria de Silvia Zanatta Da Ros e Sandra Iris Sobrera Abella discute a constituição do sujeito em contexto de grupo, a partir dos estereótipos e relações de gênero que ocorreram em situações de ensinar de aprender, no contexto do grupo. De acordo com as autoras, as relações de gênero e os estereótipos influenciaram o modo como os sujeitos foram sendo significados no interior do grupo e que estes aspectos influenciaram tanto os movimentos realizados pelos sujeitos, como a forma de constituição do grupo.

$\mathrm{O}$ artigo Questões de gênero em grupos de terceira idade, escrito por Kátia Simone Ploner, Almir Sais e Marlene Neves Strey traz uma pesquisa realizada com homens, buscando compreender porque os homens pouco participam dos grupos de terceira idade. Destaca as questões de gênero envolvidas como sexismo e discriminação. Aborda a maior valorização do trabalho em relação ao grupo e preconceitos referentes a velhice, contribuindo para compreensão das diferenças de gênero na velhice.

Agradecemos aos autores, o conselho científico, ao psicólogo Waldir Lourenço Gonçalves e às pessoas que nos apoiaram na construção deste livro. Desejamos que cada leitor encontre aqui um diálogo que o leve a questionamentos, críticas, novos horizontes e conhecimentos.

Os organizadores: Kátia Ploner

Lísia Michels, Luciane Schlindwein e Pedrinho A. Guareschi. 


\section{ÉTICA E PARADIGMAS NA PSICOLOGIA SOCIAL}

\section{Ética e paradigmas}

Pedrinho A. Guareschi ${ }^{1}$

\section{Introdução}

A ABRAPSO está sempre avançando em sua tarefa de levar aos professores e pesquisadores de Psicologia Social do Brasil novas e desafiantes reflexões sobre seu campo. O tema escolhido para o IX Encontro Regional, realizado em Itajaí-SC, está, com certeza, entre os mais provocantes. É urgente que se faça uma reflexão sobre a dimensão ética (valorativa) subjacente a todo paradigma com que trabalhamos e dentro do qual nos movimentamos na compreensão do universo e do ser humano. É assustador darmo-nos conta de quanto tempo ficamos escondendo e até mesmo negando essa problemática tão central como é a ética. Pensemos um pouco, por exemplo, sobre duas atividades comuns à psicologia: uma dos psicólogos sociais, em sua tarefa de compreensão do fenômeno psicossocial e outra dos psicólogos, em sua tarefa de terapia.

Primeiro, todo psicólogo social, ao enfrentar uma problemática social que ele julga relevante, em geral carregada com temas ligados às dificuldades por que passa uma população, ou mesmo confrontando injustiças e desigualdades sociais tem, necessariamente, em sua mente, um referencial de como as coisas devem, ou deveriam ser, quando mudadas e transformadas. Mas, qual é esse referencial? Qual o referencial que é bom, justo, aceitável? A que recorremos para dizer que tal situação deve mudar para outra, que dizemos ser a melhor? Isso é impossível sem que tenhamos uma postura ética, um referencial ético a que iremos recorrer. Só que esse referencial nunca é discutido. É suposto apenas, mas às vezes dentro de diferenças substanciais.

Do mesmo modo, o psicólogo que é solicitado a um aconselhamento psicológico ou a discutir uma situação de sofrimento psíquico, ao se propor

\footnotetext{
${ }^{1}$ Professor e pesquisador CNPq do Programa de Pós-Graduação em Psicologia da PUCRS.
}

alcançar alguma mudança no estado psíquico de seu interlocutor deve, automaticamente, se perguntar qual o parâmetro que fundamenta essa "melhoria"? Isto é, o que significa e o que fundamenta passar a uma situação "melhor"? Melhor de acordo com que critérios valorativos e éticos? Em outras palavras: qual o referencial ético que tal psicólogo e terapeuta segue? E, consequentemente, qual o referencial ético do paradigma que ele emprega em seu trabalho?

Pois são todas essas questões que estão subjacentes à questão que a ABRAPSO decidiu enfrentar em seu IX Encontro. Na conferência do encontro que levava o título da assembleia, arriscamos enfrentar três questões, dentro dessa ampla problemática. Propomo-nos discutir:

1. Quais as teorias, que fundamentam a ética, mais comuns nos dias de hoje?

2. Quais os fundamentos éticos que podem ser identificados como subjacentes a três grandes paradigmas das ciências sociais, paradigmas esses que englobam, além da dimensão ética, uma concepção de ser humano, uma visão de sociedade e uma visão de prática social?

3. Como complementação e com um olhar mais penetrante, procuramos vislumbrar qual a dimensão ética presente em três diferentes tipos de lógicas e ontologias: a lógica da identidade, a lógica da dialética e a lógica da analética.

Passemos à discussão.

\section{Principais teorias que fundamentam a ética}

A toda hora escutamos alguém dizendo que tal procedimento não ético, que tal ação é antiética, etc. Qual seria o critério para tal afirmação e julgamento? O que faz com que uma ação, uma prática e, indiretamente apenas que uma pessoa seja ética?

Quando se começa a refletir sobre o que seja ética, e sobre os fundamentos da ética, damo-nos conta de quão complexa é a questão. Mas ao mesmo tempo vemos que todos nós, de um modo ou de outro, temos nossas convicções "éticas", possuímos nossa "ética". Para termos tal "ética", temos de nos basear em algum fundamento, algum pressuposto filosófico e valorativos. Mas é interessante ver que a maioria das pessoas, apesar de possuírem esses fundamentos e pressupostos, poucas vezes 
pararam para refletir e tomar consciência de quais eles poderiam ser e de suas implicações. Essa rápida discussão quer trazer à baila esses pressupostos e facilitar, a quem desejar descobrir qual o fundamento de sua ética. Mesmo os estudos de Kohlberg $(1966,1969)$ e em parte os de Piaget (1932), apesar de ajudarem a identificar "estágios" de consciência ética, não fornecem elementos para que se possa identificar os pressupostos filosóficos e, consequentemente, se possa fazer uma crítica desses pressupostos.

Podem ser identificados dois "paradigmas" principais que fundamentariam as exigências éticas, ou os valores éticos. $\mathrm{O}$ primeiro é o da "lei natural"; o segundo é o da "lei positiva". A esses dois paradigmas acrescentamos um terceiro, que talvez não possa ser chamado de paradigma, mas que certamente questiona os dois anteriores e traz novas considerações para a discussão da problemática da ética: a ética tomada como instância crítica.

\section{O paradigma da lei natural}

O grande referencial do paradigma da lei natural é a "natureza". Esse referencial tem a pretensão de dizer que a partir da atenção dada à "natureza", é possível, de um lado, estruturar uma ética que governe todos os povos e em todas as épocas e, de outro lado, é possível uma "fonte" para essa ética que não sejam os costumes ou instituições de determinados povos ou nações. Entre os defensores de tal paradigma podemos citar Aristóteles, os estoicos, Cícero e muitos outros seguidores até os dias de hoje (quem sabe até você mesmo que está lendo esse trabalho).

Essa tradição dividiu-se em duas vertentes: uma pré-moderna, religiosa, inspirada em Tomás de Aquino, centrada na ideia de um Criador e numa ordem imutável estabelecida por Deus; outra moderna, secular, inspirada nos escritos de Grotius e John Locke, fiel à mentalidade do mundo moderno que, sem negar a origem divina da natureza, investe na defesa dos "direitos humanos". João Batista Libâneo diz que a primeira se caracteriza como o "momento do objeto", como pré-moderna; a segunda como o "momento do sujeito", típica do pensamento moderno. Uma privilegia a estabilidade do objetivo e a outra a liberdade e a iniciativa do subjetivo. Mas para ambas o critério que as fundamenta é algo exterior: a natureza como produto de Deus Criador para a primeira, ou a dignidade e os direitos fundamentais do ser humano que podem ser racionalmente conhecidos e justificados, para a segunda.

\section{O paradigma da lei positiva}

O paradigma da lei positiva surge como reação ao paradigma da lei natural, tanto na sua versão religiosa, como na versão secular. Há uma rejeição, tanto a nível epistemológico, como a nível ideológico, de um apelo a uma ordem natural como referencial ético. A nível epistemológico, a partir do relativismo cultural, questiona-se a possibilidade de dar conteúdo concreto a leis ditas naturais, que sejam as mesmas em todas e para todas as épocas e culturas. A nível ideológico, a experiência histórica do abuso, tanto de poderes religiosos, como civis, de apelar para leis "naturais" para esmagar seres humanos que se opunham a determinados regimes, levou à rejeição de uma ordem humana e social determinada por uma lei natural preestabelecida. O critério ético passa a ser o que foi escrito e promulgado após as diversas instâncias de discussão. É o que passou a se chamar de contratualismo. Uma vez discutida e estabelecida uma negociação social, ela passa a ser válida. Com isso se evita a arbitrariedade e pode-se apelar para algo objetivo que foi formulado e promulgado. Podemos nos libertar, assim, de uma natureza cega, de um lado, e dos mandos e desmandos autoritários de governantes e grupos, de outro.

Pode-se perceber logo que se as leis fossem justas, discutidas democraticamente e aplicadas da maneira mais imparcial possível, o estado de direito poderia ser um forte defensor do direito e das liberdades dos seres humanos. Mas o que acontece quando os governadores e os juizes são autoritários e quando alguns legislam em causa própria? Que dizer quando grupos e minorias poderosas forçam a criação de acordos e negociações em proveito próprio? Pode-se ainda dizer que o que é instituído é ético? Que dizer de exemplos como o das ditaduras militares e especificamente o caso do Brasil e outros países da América Latina, onde alguns grupos, à base da força e da pressão, impuseram sobre uma maioria suas vontades e seus privilégios? E tudo através de "constituições" escritas e promulgadas.

Como acabamos de ver, o fundamento da ética é colocado por alguns na lei natural (tanto por ser essa lei originada de um Deus Criador, ou por estar radicada na dignidade do ser humano e de seus direitos inalienáveis), 
ou num positivismo jurídico, que se radica no texto de uma lei escrita e promulgada.

Mas damo-nos conta também das limitações e perigos que se originam de tais pressupostos. Que fazer, então? Haveria outra alternativa para fundamentar a dimensão ética? O que seria, afinal, a ética? É esse ponto que merece uma atenção especial.

\section{Ética como instância crítica}

$\mathrm{Se}$ as colocações acima discutidas mostram suas limitações e precariedades, ao mesmo tempo indicam pistas por onde se pode iniciar a busca de uma fundamentação ética das ações e relações. Mas é decisivamente importante que, ao perseguirmos tais fundamentações, tenhamos sempre em mente seus possíveis limites. E a isso poderíamos chamar de postura crítica diante de todo criado e de todo o institucionalizado. Enquanto permanecermos dentro do humanamente instituído, sem apelarmos para o eterno e o transcendente, temos de reconhecer nossa limitude histórica. E ao reconhecermos essa limitude, temos de deixar sempre uma porta aberta a porta de possibilidade de alternativas, de crescimento, de transformações, de aperfeiçoamento.

Nesse contexto, creio que nos seria muito útil uma noção de ética como sendo uma

instância crítica e propositiva sobre o dever ser das relações humanas em vista de nossa plena realização como seres humanos (Dos Anjos, 1996, p.12).

Perscrutando a fundo essa formulação, podemos extrair dela duas dimensões fundantes: a dimensão crítica e propositiva, e a dimensão das relações. Elas são centrais para a compreensão mais profunda da ética.

\section{a) A dimensão crítica e propositiva}

A dimensão crítica da ética significa que ela não pode ser considerada como algo pronto, algo acabado. Ao contrário, ela está sempre por se fazer. E ao mesmo tempo ela está presente nas relações humanas existentes. À medida em que ela se atualiza, passa a sofrer suas contradições e por isso deve ser questionada e criticada. Ao mesmo tempo ela tem de ser propositiva. Não pode se furtar a colocar exigências e desafios. Mas esses desafios e exigências podem ser reelaborados, redimensionados, refeitos e retomados. E a ética é sempre do "dever ser das relações humanas em vista de nossa plena realização". É uma busca infinita, interminável; é uma consciência nítida de nossa incompletude; é um impulso permanente em busca de crescimento e transformação.

Não seria fora de propósito mencionar aqui a posição de alguns autores da Escola Crítica, como Karl Otto Apel e Jürgen Habermas, que procuram resgatar a dimensão ética a partir do discurso. O discurso é o que temos de mais próximo, de mais real, e ao mesmo tempo de mais interminável; ele possui a maior possibilidade de criar todas as alternativas possíveis. E ao mesmo tempo ele possui pressupostos indispensáveis, sem os quais ele mesmo não pode se sustentar, isto é, ele traz consigo também uma infinidade de caminhos diferentes, e entre eles a possibilidade de seu próprio resgate. Os pensadores acima citados são chamados por Lima Lopes (1996, p.31), de

críticos, somando tanto a crítica kantiana quanto a marxista; podem ser tidos como herdeiros dos ideais de liberdade dos modernos ao mesmo tempo que levam a sério a impossibilidade de existência do ser humano não socializado.

É minha convicção que é fundamental enfatizar a dimensão da crítica ao se discutir a questão da ética. Num trabalho anterior (Guareschi, 1992, p.5-34) tentei mostrar como o uso cuidadoso e sério da crítica, mesmo ao se discutir as diferentes teorias científicas, leva à própria evidência da impossibilidade de uma ciência, ou de uma prática científica neutra, isto é, ;em uma dimensão ética. A crítica resgata a dimensão ética de toda ação humana. Mas ao mesmo tempo não fecha a questão sobre a presença de uma dimensão ética específica. Aliás, a própria Teoria Crítica (também chamada de Escola de Frankfurt ou Crítica da Ideologia) tem como pressuposto a impossibilidade de neutralidade das ações humanas. Toda ação humana, segundo essa escola de pensamento, deve ter como finalidade iluminar e emancipar; a ação que se diz "neutra", se não estiver direcionada a tais fins, possivelmente estará servindo a propósitos contrários, de ocultação da realidade e de manipulação das consciências (Geuss,1988).

O próprio John B. Thompson (1995), um dos autores que mais amplamente e criticamente analisa a ideologia, define esse conceito como tendo "uso de formas simbólicas que servem para criar ou manter relações 
de dominação". Uma forma simbólica só é ideológica quando se puder mostrar que ela serve aos propósitos de criar ou manter relações que sejam de dominação, isto é, relações assimétricas, desiguais, injustas. Dominação é aqui um conceito diferente de "poder". "Poder" é uma capacidade, uma qualidade individual de pessoas, algo singular, particular. Nesse sentido, todos os que "podem" fazer algo (trabalhar, falar, escrever etc.) têm um "poder". Já "dominação" é uma "relação", isto é, sempre se dá entre dois ou mais sujeitos e acontece quando há uma expropriação de poder, isto é, quando um retira, de maneira assimétrica ou injusta, um poder de outro parceiro. Para essa concepção de ideologia, então, a dimensão "ética", isto é, a dimensão do "dever (ou não dever) fazer", está presente. A análise ideológica, nesse sentido, é sempre uma demonstração e uma denúncia da existência de relações assimétricas, desiguais. Ela leva, naturalmente, à constatação de situações que provocam uma tomada de posição, que dificilmente vai deixar as pessoas impassíveis, tranquilas. Esse é o grande risco de se tomar ideologia na acepção crítica. E ao mesmo tempo a grande vantagem. Na verdade, de que ajuda aos grupos humanos dizer, simplesmente, que "as coisas são assim", sem que se apresentem elementos de transformação e superação de tais situações? Mas o mais importante, contudo, é o fato de que uma postura teórica que simplesmente toma a ciência como uma prática que diz "como as coisas são", esconde, por detrás dela, uma postura conservadora. E tanto uma, como a outra, possuem dimensões éticas, pois ser conservador (isto é, permitir que as coisas sejam assim, ou impedir que elas mudem), é uma ação tão ética como lutar pela mudança (lutar para que a situação se transforme). Para uma formulação clara e precisa dessa questão veja-se Israel (1972).

\section{b) A dimensão da relação}

Uma segunda dimensão que gostaríamos de discutir a partir da formulação acima, é a questão das "relações", ou da ética enquanto ética das relações. Essa é uma discussão extremamente provocante. Dentro de uma cosmovisão individualista, onde o ser humano é considerado como indivíduo (o indivisum in se et divisum a quolibet alio, isto é, o que é um/uno, mas que não tem nada a ver com qualquer outra coisa), sob o império do liberalismo, fica difícil de se perceber que a ética só pode ser dita das relações e onde ela mesma é sempre uma relação.
Entendemos por relação a "ordenação intrínseca de alguma coisa em direção a outra", que a filosofia define como ordo ad aliquid. Em outras palavras, relação é algo que não pode ser sem o outro. Vejamos como a questão da relação tem a ver com a justiça e a ética.

Pegoraro (1996) publicou um livro cujo título é: "Ética é justiça". O que o referido autor faz é recuperar a argumentação de Aristóteles, na "Ética a Nicômacos", onde ele afirma que a justiça é a virtude central da ética, pois ela comanda os atos de todas as virtudes.

Essa forma de justiça não é parte da virtude, mas a virtude inteira e seu contrário, a injustiça, também não é uma parte do vício, mas o vício inteiro (Aristóteles, 1985).

Dizer que ética é justiça, torna-se muito claro quando pensamos sobre o que significa "justiça". Justiça provém de jus, que no latim quer dizer direito. Alguém é justo quando estabelece relações com outros seres que sejam justas. Em outras palavras, alguém sozinho não pode ser justo. Alguém sozinho pode ser alto, branco, simpático etc., pois isso não implica "relação", isto é, não implica "outros". Agora, justo, ele não consegue ser sozinho, pois a justiça, ou a injustiça, só entra em cena no momento em que alguém se relaciona com outros. Isso quer dizer que é só à "relação" que se pode aplicar o adjetivo "justo"; tal adjetivação não pode ser dita de um polo apenas da relação. Eu sou justo quando estabeleço relações com outros que sejam justas, isto é, que respeitem os direitos dos outros. Justiça tem a ver, pois, com o respeito aos direitos das pessoas. Há justiça quando os direitos das pessoas são respeitados.

Do mesmo modo com a ética. Dizer que ética é relação, ou dizer que ética só se pode aplicar às "relações", é afirmar que ninguém pode se arvorar do predicativo de "ético" a partir de si mesmo, como quer, exatamente, o liberalismo. O pensamento liberal, ao partir da definição de ser humano como "indivíduo", centraliza tudo no "eu", no sujeito da proposição. Perdemos a dimensão relacional e como consequência mistificamos o verdadeiro sentido de ética. Chegamos, assim, a absurdos sociais como os que vivemos hoje, em que um terço da população não possui seus direitos garantidos e nos blasonamos como éticos, ou como um país onde exista ética. Por incrível que pareça, quem vai decidir se somos, ou não, éticos, são os outros. Isso parece chocante e de fato o é, dentro da cosmovisão egocêntrica e individualista, como é a cosmovisão do liberalismo. 
No documento Exigências Éticas da Ordem Democrática, da CNBB (1994), a seguinte afirmação vem mostrar quem é o juiz da ética numa verdadeira democracia:

A existência de milhões de empobrecidos é a negação radical da ordem democrática. A situação em que vivem os pobres, é critério para medir a bondade, a justiça, a moralidade, enfim, a efetivação da ordem democrática. Os pobres são os juizes da ordem democrática de uma nação (n.72).

E importante ainda, como o faz Dussel (1986), distinguir entre moral e ética. Moral são os costumes vividos numa determinada sociedade, aquilo que os grupos e pessoas estabeleceram como sendo comum, necessário para $\mathrm{o}$ andamento e prosseguimento da ordem normal estabelecida. Nesse sentido, todo poder constituído "estabelece as próprias práticas como boas" (Dussel,1986, p.43), sejam elas quais forem. A ética, porém, refere-se aos princípios fundamentais de justiça, igualdade e solidariedade. A ética está continuamente na busca de uma sociedade mais justa e fraterna e do estabelecimento de normas que sejam mais e mais construtoras de seres humanos livres e solidários. A ética busca a libertação pessoal e social das pessoas e das situações de injustiça. A ética é a crítica da moralidade.

Podemos acenar aqui para a questão da comunicação: a situação em que se encontra a alocação dos meios de comunicação, embora sendo legal, poder-se-ia dizer ética? Estão respeitados os direitos à informação e à comunicação dentro da atual legislação brasileira?

A educação sistemática, em geral, forma, ou conforma, as pessoas a obedecerem e a se ajustarem aos padrões estabelecidos, isto é, aos padrões morais dos grupos e sociedades. A verdadeira educação, libertadora e autônoma, educa para a formação de uma consciência crítica, capaz de continuamente questionar a situação presente, denunciando profeticamente suas lacunas e anunciando novas perspectivas de crescimento e libertação.

Deste modo, a consciência "moral", a partir dos princípios morais de um sistema que seja dominador, (como é o caso de sistemas onde há apenas alguns que podem falar e a maioria não tem o direito de dizer sua palavra), cria uma consciência tranquila, que não dói, ante uma práxis que o sistema aprova, mas que pode ser originalmente perversa, de dominação (Dussel, 1986, p.46).
Vimos, até aqui, os principais fundamentos aos quais se apela ao se discutir questões éticas. Cada paradigma científico, velada ou explicitamente, possui determinada dimensão ética e, consequentemente, há um fundamento para essa ética. Depende de cada professor ou pesquisador identificar qual seja essa ética e qual seja o fundamento dessa ética.

\section{Três grandes paradigmas e seus fundamentos éticos}

Considero essa a parte central dessa comunicação. Vou apresentar três grandes cosmovisões que, no meu entender, representam três grandes paradigmas. Discutirei, nesses paradigmas, quatro dimensões que vejo presentes em todo paradigma: a concepção de ser humano, a concepção valorativa ou ética (que é o que nos interessa aqui), a concepção de social desse paradigma e finalmente a dimensão da prática, isto é, como só comportam e se relacionam as pessoas que aceitam e se guiam por determinado paradigma. Essa última parte é extremamente complexa e arriscada, pois facilmente podemos nos comportar e relacionar de maneira bastante diversa do que pensamos e falamos. De qualquer modo, tomandose tais comportamentos e relações como padrões gerais, podemos mostrar que eles supõem tal concepção de ser humano, determinada ética e determinada concepção do que é social.

Existem inúmeras definições do que seja um paradigma. Alguns analistas da obra de Thomas Kuhn chegaram a identificar ao redor de 60 acepções diferentes em seu livro A Estrutura das Revoluções Científicas. Atenho-me aqui a uma noção de paradigma que julgo bastante prática e que assemelha-se muito ao que chamamos também de cosmovisão. Estou ciente de que há muitas outras acepções, mas certamente a que apresento responde a muitas das necessidades teóricas e práticas que enfrentamos.

Um paradigma, como o tomo aqui, possui, pelo menos, quatro elementos, que mencionamos acima. Um primeiro é de determinada concepção de ser humano. Quem é o ser humano para determinada teoria ou paradigma? Todos temos um referencial paradigmático e nesse referencial a concepção de quem sou eu, de quem é você, é indispensável. É verdade que muitas vezes não sabemos qual é, mas que nós o temos, isso é indiscutível.

A segunda dimensão é a dimensão de valor, ou a dimensão ética, que é a que nos interessa nessa discussão. O termo "ética", como vimos na 
primeira parte, é complexo e difícil de ser discutido. Tem a ver com cultura, com a moral, com a tradição, com os costumes, com os valores em geral. É um valor que não é nem econômico, nem natural, mas que faz com que nós reajamos, e nos comportemos, de acordo com determinadas normas, tradições, negociações, etc. Valor é um dos termos pouco refletidos em psicologia, e em psicologia social de modo especial.

Há também uma dimensão muito interessante: o que é "social" para nós? Isso está intrinsecamente ligado ao tipo de sociedade que a gente imagina que seja o melhor, que seja o bom, que nós defendemos, mesmo que não tenhamos clareza. Todos nós temos uma concepção de social e defendemos uma maneira de viver em grupo, que muitas vezes não é pensada e refletida. Muitas vezes, nesse aspecto, dizemos uma coisa e fazemos outra.

Enfim, a única coisa que a gente pode ver concretizada, num paradigma, é a dimensão das condutas, dos comportamentos e das relações. É a partir dessas condutas, comportamentos e relações, que podemos visualizar, em parte, qual a concepção de ser humano que nós temos, em que ética nos fundamentamos e que tipo de social eu pressuponho.

O quadro (1) a seguir nos orientará em nossas discussões:

\begin{tabular}{|c|c|c|c|}
\hline $\begin{array}{l}\text { Concepção de } \\
\text { Ser Humano }\end{array}$ & $\begin{array}{c}1^{\mathrm{o}}: \\
\text { Indivíduo }\end{array}$ & $\begin{array}{c}2^{\circ}: \\
\text { Pessoa }=\text { relação }\end{array}$ & $\begin{array}{c}3^{\circ}: \\
\text { "Peça da máquina" }\end{array}$ \\
\hline Ética, Valores & Liberal capitalista & $\begin{array}{l}\text { Comunitário, } \\
\text { Solidário }\end{array}$ & $\begin{array}{l}\text { Coletivista } \\
\text { totalitário }\end{array}$ \\
\hline $\begin{array}{l}\text { Concepções de } \\
\text { "social" }\end{array}$ & Soma de individuais & $\begin{array}{l}\text { Dialético - } \\
\text { Relacional }\end{array}$ & $\begin{array}{l}\text { Reificado — "uma } \\
\text { coisa" }\end{array}$ \\
\hline $\begin{array}{l}\text { Comportamentos, } \\
\text { Relações }\end{array}$ & $\begin{array}{c}\text { Individualismo } \\
\text { Competitividade }\end{array}$ & $\begin{array}{l}\text { Solidariedade } \\
\text { Cooperação }\end{array}$ & $\begin{array}{c}\text { Massificação } \\
\text { Anonimato }\end{array}$ \\
\hline
\end{tabular}

Analisamos cada um desses paradigmas, mostrando como as quatro dimensões acima se mostram diferentemente em cada um deles.

\section{O paradigma liberal capitalista}

O paradigma liberal capitalista vê o ser humano como indivíduo. Atenção para esta palavra indivíduo, que a gente usa a todo momento. Seria necessário limpar esse conceito, e tomar consciência do que ele realmente significa.
"Indivíduo", como entendido na filosofia clássica e cuja definição eu assumo aqui, e que é, também, o sentido que é dado dentro da filosofia que fundamenta o liberalismo, se define por duas dimensões centrais, como já vimos na primeira parte. Significa, em primeiro lugar, aquele que é um, singular, único. Essa é a primeira dimensão. A segunda, é que ele é um, mas não tem nada a ver com o outro, isto é, ele é isolado, fechado sobre si mesmo. Atenção para a segunda dimensão. É aqui que está a diferença entre indivíduo e pessoa, como veremos logo adiante.

Que tipo de ética sustenta tal concepção de ser humano? É o que denominamos de ética liberal. O liberalismo, na essência, tem como doutrina, como móvel central, como dogma, que o ser humano é um e não tem nada a ver com os outros. Os outros que se virem, cuidem de sua vida. A expressão popular disso é: quem pode mais chora menos; cada um por si, ninguém por todos (o "deus por todos", presente na nossa linguagem, não é exatamente o Deus comunidade, sociedade, pensado pela teologia cristã, bíblica, pois esse Deus é essencialmente trindade, comunhão de pessoas que são puras relações; é, isso sim, o deus ideologizado pelo próprio liberalismo, que transforma Deus na imagem e semelhança do indivíduo egoísta e autocentrado do liberalismo). A ética aqui é individualizante e egocentrada, que busca apenas seu próprio interesse, sem se preocupar com o "outro".

O social, nessa concepção, não existe. Existe apenas algum aglomerado que se constitui através da soma de individuais. E o sistema social que, como a mão para a luva, ou vice versa, se materializou a partir dele, é o que chamamos de capitalismo, o capitalismo liberal, que se concretizou mais formalmente e se generalizou a partir do século dezoito e dezenove. O lema desse capitalismo, laissez faire, laissez passer, é exatamente a concretização da filosofia liberal dentro da concepção de ser humano indivíduo.

Que condutas, ou comportamentos, estão aqui presentes? De um lado o individualismo, o egocentrismo, cada um cuidando do que é seu. E quanto às relações, a mais central, que é a própria alma do modelo, é a competitividade. Competitividade significa luta, guerra. O dogma do liberalismo é que sem competição não há progresso. Por isso a competição é essencial, é um pressuposto metafísico do sistema. 
Mas atenção que a competição de que falamos aqui, não é a competição do mercado, onde nós colocamos o que temos de melhor, para que nossos irmãos/ãs sejam servidos e possam escolher o que acharem melhor. A competitividade aqui é aquela que se estabelece entre pessoas. Tal competitividade necessita a exclusão de alguém e se transforma num darwinismo social, com a vitória do mais forte.

$\mathrm{O}$ individualismo, nesse contexto, se apresenta na expressão paradoxal de Farr (1991), como uma "representação coletiva": nada que tenha se tornado tão "coletivo", do que exatamente esse comportamento "individual". E na máquina liberal em que nós estamos, sempre tem que haver excluídos. E essa competição deve ser de âmbito mundial. Dentro da filosofia liberal, não há espaço para colaboração, cooperação e solidariedade. Vale a lei do mais forte.

\section{O paradigma coletivista-totalitário}

No ângulo oposto, temos um outro paradigma, em que o ser humano é um pedaço de um todo. Ele é "uma peça da máquina”. Não interessa o ser humano em si, o que interessa é o grupo, a organização, a instituição, o partido, o Estado.

A ética desse paradigma é a ética totalitária. O que tem valor é o todo o sistema. $\mathrm{O}$ específico, a diferença, não conta aqui. $\mathrm{O}$ que embasa isso é o totalitarismo ou coletivismo. Precisamos ser cuidadosos e humildes aqui pois, se pensarmos bem, todos nós somos um pouco totalitários. Sempre que nós temos dificuldade de aceitar e de lidar com o diferente, demonstramos certos traços de Nazismo e de Fascismo. Por quê? Vejamos com mais detalhe.

O social presente em tal paradigma é um social reificado. É o social "durkheimiano", o social tão real como uma "coisa". Tal visão deu origem a sistemas totalitários, como o Nazismo e o Fascismo, que dissolvem todas as diferenças e tentam unificar a nação. As diferenças são suprimidas. Como surgiu o Nazismo? Que acontecia com a Alemanha no tempo de Hitler? O partido Socialista estava crescendo, com perigo de tomar o poder. A elite se organiza para evitar a perda da hegemonia. Só que a elite escolhe, em geral, uma ideologia para se esconder por detrás. E a ideologia que escolheram foi, no caso, a da raça pura. Se os alemães se organizassem, todos, (isso é importante, unir o povo!), a Alemanha iria mandar em todo o mundo por ao menos mil anos.

O mesmo fez Mussolini na Itália, de maneira fantástica. Também ali tinha-se de unir os trabalhadores. Isso ele conseguiu com a Carta del Lavoro, conseguiu unir a todos, pois assim a Itália voltaria ao esplendor do Império Romano, simbolizado pelo fascis, o facho. Getúlio Vargas, naquela época, emprestou a Carta del Lavoro de Mussolini para subordinar o sindicalismo brasileiro ao poder do Estado. Na Itália ela teve uma vida curta, mas aqui ela durou até 1988, quando se re-escreveu a Constituição. Apenas a partir daí nós tivemos um sindicalismo livre.

Que tipo de comportamento vemos aqui? A massificação, o anonimato, a burocracia, essa burocracia terrível que mata, que transforma as pessoas em coisas, onde a ordem, a organização, estão acima de tudo. É o predomínio da máquina sobre o ser humano.

\section{O paradigma comunitário-solidário}

Analisamos, até aqui, dois grandes paradigmas que se situam em pontos extremos. Há uma alternativa a isso tudo? E o que pretendo discutir agora, ao abordar a coluna do centro, onde pretendo fazer um contraponto às outras duas e tentar, ao mesmo tempo, mostrar que aqui se pode ver um tipo diferente de ser humano, de ética, de social e de práticas.

O ser humano é visto aqui como relação, isto é, como pessoa. Eu reservo o conceito de pessoa para esse paradigma. O conceito de ser humano pessoa=relação vem do filósofo cartaginês, do norte da África, Agostinho. Ele distinguiu claramente entre indivíduo e pessoa. Indivíduo é aquele que é um, e não tem nada a ver com os outros. Pessoa é aquele que é um, mas só pode ser, se tem outro, necessita de outro para poder ser. É isso que é relação. Relação é aquilo pelo qual uma coisa não pode ser, sem outra. Nós somos seres singulares, sim. Agora, a minha subjetividade, aquilo que me constitui, é o mundo todo, são todos os outros.

Marx, na tese sete sobre Feuerbach, diz que o ser humano é a soma total de suas relações. Nós somos os bilhões de relações que estabelecemos no dia a dia.

Alguns usam a palavra sujeito para isso. Um pouco, tenho a impressão, a concepção de Guattari. Sujeito pode ser um termo interessante. 
Por quê? Por que sujeito é o subjectum, e o subjectum, etimologicamente é o que está por baixo, o fundamento, ou o poste, o suporte onde nós penduramos, ou amarramos algo. Se eu digo que alguém é simpático, eu "amarro" nesse alguém um verbo, "é" e um predicado, "simpático". Eu conceituo a subjetividade nessa dimensão. Distingo entre singularidade e subjetividade, mas ambas se referem à mesma realidade. Singularidade é aquela dimensão do ser humano segundo a qual ele é único, irrepetível, uno Acentua-se, então a dimensão da unicidade. Ele é um porque nos milhões de relações que estabelece, ele recorta pedacinhos diferentes e forma uma grande colcha de retalhos com a qual ele constrói a sua subjetividade. A subjetividade, então, é o conteúdo, são os retalhos que compõem seu ser, é conjunto total de suas relações; são os outros, o mundo. Enfatiza-se, então, a dimensão da constituição do ser. Somos, assim, misteriosamente, os outros, apesar de sermos singulares, porque recortamos diferentemente das relações.

Agora, o que faz a ética liberal? Ela nega a relação. Exatamente isso. A ética liberal afirma: eu sou eu, e ponto final; não tenho nada a ver com os outros. Pode-se perceber claramente como isso, depois, repercute tremendamente na prática.

Temos muitas palavras para expressar a dimensão ética desse paradigma. Nenhuma delas dá realmente conta de tudo. Cada uma procurou ver uma dimensão diferente. Uma delas, por exemplo, é solidarismo. O perigo disso é que ela está sendo apropriada até para nome de partido político. Um termo bom foi o criado por Mounier - o personalismo. Deriva do próprio termo pessoa. Um termo interessante é o amorismo, de Teillhard de Chardin. Ele dizia que o mundo foi fecundado pelo divino, por isso o mundo é divino que as relações que devemos estabelecer com todo mundo, são relações de amor entre os seres humanos e deles com as coisas todas. Um tanto parecido com o fraternismo, ou sororismo de Francisco de Assis, no qual, também todos somos irmãos/irmãs com o mundo: irmão sol, irmã lua, irmã água, irmão lobo, irmã morte... São recuperadas aqui até mesmo as questões referentes à ecologia. Isso é bem interessante.

Um último termo que também é, às vezes, empregado para designar essa dimensão valorativa, é comunitarismo e com isso quero entrar já para discussão de um novo conceito de social e na questão do tipo de sociedade que, talvez, possa melhor ser expressa pelo conceito de comunidade.
A discussão da comunidade é um tema de que eu gosto. Qual seria melhor maneira de viver? Onde as pessoas se realizariam plenamente? É importante aqui resgatar a dimensão comunitária e o termo comunidade. Comunidade, como entendida aqui, é um tipo de vida em sociedade, onde todos são chamados pelo nome, onde todos são identificados e têm um nome.

Essa é, para mim, uma definição muito significativa. Em tal maneira de viver, todos têm voz, todos têm vez. Ninguém é apenas um número, nem é alguém fechado sobre si mesmo, que não tenha nada a ver com os outros. Os grandes filósofos éticos da atualidade são praticamente unânimes em afirmar que diante das irracionalidades globais em que viemos, o retorno à comunidade, ao tipo de vida onde há participação de todos, seria uma maneira de resgatar o ser humano e a vida social.

Os comportamentos e relações que nascem daqui são de partilha, solidariedade, colaboração, cooperação. As relações são igualitárias e fraternas. A participação se dá em nível simétrico a partir da ação e do diálogo comunicativos.

Chegamos ao fim dessa segunda parte. O que gostaria de deixar claro é que um paradigma tem, necessariamente, uma dimensão valorativa, ética. Isso foi negado durante vários séculos e a modernidade tentou enfatizar que a ciência e as teorias deveriam ser neutras. Mas a dimensão ética está tão presente num fenômeno, como está a dimensão metafísica (sua visão do que é a realidade) e a dimensão epistemológica.

\section{Ontologias, lógicas, métodos e ética}

Nessa terceira parte arriscamos algumas reflexões sobre uma discussão que ainda não está de todo amadurecida, mas que merece ser enfrentada. A lógica fundamenta determinada ontologia, determinada convicção daquilo que constitui o real. Qual a ética subjacente a diferentes ontologias e a diferentes tipos de lógica? Se a ética se manifesta nas diferentes teorias, ela pode ser também identificada, com alguma reflexão, nas diferentes lógicas. poderíamos identificar três tipos de lógica: duas comum ente discutidas e uma terceira não tanto mencionada.

Um primeiro tipo de lógica é a que se costuma denominar de lógica da identidade, ou lógica do absoluto. Os seres são vistos como totalidade, como unos em si mesmos e totalmente separados um do outro. Não há 
nenhuma relação que os una. A lógica da identidade afirma que um é um, outro é outro, que eles nada tem a ver um com o outro e que nada pode ser e não ser no mesmo tempo.

A ética subjacente a tal lógica é a ética do indivíduo, ética da unicidade, da totalidade, de coisas completas em si mesmas. Tal lógica é absolutamente coerente com o primeiro e o terceiro modelo de paradigmas que vimos na segunda parte dessa discussão. O paradigma individualista e o paradigma totalitário tem em comum o fato de serem completos em si mesmos, seja o um ou seja a totalidade (o conjunto de seres, o sistema, o grupo). Uma lógica e paradigmas que levem a um fechamento sobre si mesmos, podem facilmente levar à exclusão dos outros, à não necessidade de participação, de diálogo, de inclusão dos outros. Essa seria uma lógica individualista, egocentrista.

Um segundo tipo de lógica é a que podemos chamar de dialética. A dialética se define por uma ontologia que considera o ser como aberto, relacional. Na dialética o "outro" sempre está presente.

O paradigma comunitário-social, visto acima, coaduna-se com tal tipo de lógica. O ser humano é visto como pessoa=relação. Mas tal paradigma não explicita, na verdade, que tipo de relação é estabelecida entre as diferentes pessoas. Apenas diz que há uma implicação do outro na concepção de ser humano. Esse "outro", contudo, pode ser tomado de diferentes maneiras, ou melhor, como fruto de diferentes relações, como veremos a seguir. E a partir da maneira diferente como entendemos o "outro", teremos tipos diferentes de lógicas.

Tentemos aprofundar essa problemática. $\mathrm{O}$ pano de fundo da filosofia ocidental é a filosofia da totalidade, da identidade, como vimos. Como muito bem diz Oliveira (1996 p.391), a filosofia do Ocidente sempre pensou o real como totalidade, como um todo fechado em si mesmo que, enquanto todo, é sempre "o mesmo". A partir da interioridade do mesmo, procedem o momentos diferenciais, mas como diferença pensada a partir da identidade originária, isto é, trata-se de algo diferente "no mesmo". $\mathrm{Na}$ totalidade fechada é impossível a alteridade. A totalidade solipsista só conhece um outro que é ele mesmo.

Ao percorrer a reflexão filosófica percebemos que essa ontologia da identidade-totalidade foi confrontada por outra ontologia, como estávamos iniciando a discutir, a ontologia da dialética, onde o "outro" é explicitamente instituído. Mas ao aprofundarmos a reflexão, percebemos que o "outro" foi tomando diferentes acepções. Dussel (1986, p.173) faz uma excelente análise mostrando como o "outro" foi, e ainda é, muitas vezes, pensado como o outro ontologizado, como o foi pela filosofia grega; nesse sentido, o outro é um ser "que é", eterno, imutável em seu constitutivo último. Esse "outro" passou a ser visto como alguém racionalizado, como um ente da razão principalmente a partir da filosofia moderna desde Descartes. Ele também foi e ainda é, considerado como o "outro" "coisificado" (ontificado), como o pensa a subjetividade moderna europeia e manipulado pelo cientificismo atual como decorrência mesma de todas as correntes filosóficas empíricas pragmáticas que vigem no tempo presente.

Dussel (1977), ao discutir essa questão, estabelece algumas distinções que ajudam a lançar uma luz mais profunda na questão da ontologia, da lógica e da ética. Sem abandonar a questão da relação, isto é, da visão do só humano como pessoa=relação, onde um ser implica necessariamente n outro, ele mostra que esse "outro" pode estar presente no "mesmo" de duas maneiras diversas: como "di-ferente" e como "dis-tinto".

Na primeira, o "outro" é o "di-ferente", do latim, dis, que significa divisão ou negação; e ferre, que significa levar com violência, arrastar. Nesse sentido, o diferente é o arrastado desde a identidade original e coloca-se como o oposto; é a dialética monológica.

Na segunda, o "outro" é o "dis-tinto", de dis e tingere, que em latim significa tingir, pintar; também é separado, é o outro, não contudo arrastado para fora, mas possuindo sua identidade e estabelecendo com o "mesmo" relações de diálogo, construtivas, de convivência: é a analética dialógica. Essa é a nova lógica, com a diferença que nesse segundo tipo há a presença de uma ética respeitosa e não de uma dominação como no outro como "diferente". Nisso consiste, no dizer de Dussel (1977, p.98), "toda a eticidade da existência".

Em dois trabalhos anteriores procuramos discutir essa problemática (Guareschi,1998 - Representando a Alteridade e em Campos e Guareschi Paradigmas em Psicologia Social - A perspectiva latino-americana, 2000). Nesse último, argumentamos sobre a emergência dessa nova dimensão paradigmática. Dentre os diversos paradigmas que foram se 
constituindo como hegemônicos no decorrer da história do pensamento, nenhum se deteve para se perguntar sobre a dimensão ética de toda teoria ou cosmovisão. Discutia-se a dimensão metafísica (ontológica) e a dimensão epistemológica das teorias, mas nunca se aprofundava a dimensão ética. Não seria, talvez, pelo fato de essas teorias e esse pensamento hegemônico serem produzidos por pensadores e povos que exerciam, na época, poder de dominação sobre todos os outros? Esse novo modo de pensar analético está sendo gerado a partir dos povos oprimidos, ou vítimas do holocausto, como no caso de Levinas e Zygmunt Bauman, ou a partir de continentes mantidos sob dominação, como no caso de Dussel.

Torna-se assim praticamente impossível discutir a questão da analética sem ter presente a questão da ética. Essa é a diferença do novo tipo de lógica, do novo paradigma ontológico. Os diversos autores tentam introduzir essa nova dimensão do pensar analético, ligado à ética, que se coloca entre a identidade do conceito em si e para si de um lado e a ideia absoluta da totalidade de outro lado. Toda nossa postura implica uma dimensão ética. E nossa ética vai se diferenciar de acordo com nossa relação diante do "outro". A ontologia da identidade, ou da totalidade, pensa ou inclui o "outro" como intranscendente. Já a analética é uma postura, uma lógica que pretende ir mais além, acima, que vem de um nível mais alto ("ana" significa além - "trans") que o método dia-lético. O método dia-lético é o caminho que a totalidade realiza em si mesma: dos entes ao fundamento e do fundamento aos entes. $\mathrm{O}$ método analético parte do "outro" como livre, como além do sistema da totalidade; parte, então, de sua palavra, da revelação do outro, que confiando em sua palavra, age, trabalha, serve, cria. Dussel (1977, p.200-201) mostra o novo da analética: a lógica dialética é a expressão dominadora da totalidade desde si mesma; a passagem da potência ao ato do "mesmo". O método analético é a passagem ao justo crescimento da totalidade desde o outro, para "servi-lo" criativamente. A passagem da totalidade a um novo momento de si mesma é sempre dia-lética. A verdadeira dialética parte do diálogo do "outro" e não do "pensar solitário consigo mesmo". A verdadeira dia-lética tem um ponto de apoio ana-lético; ao passo que a falsa dialética é simplesmente um movimento conquistador. $\mathrm{O}$ individualismo e o egocentrismo, expressões lógicas e correlatas da "totalidade", têm como ponto de partida o "nósmesmos". As coisas passam a tomar sentido apenas a partir de nós. Somos nós que decidimos, nós que dizemos o que é bom ou mau, certo ou errado.

\section{Conclusão}

Movi-me através de três pontos básicos: no primeiro discuti as várias teorias que fundamentam a ética e defendi como mais abrangente e explicativo o entendimento da ética como "uma instância crítica e propositiva do dever ser com respeito às relações humanas conseguida através de uma ação comunicativa". No segundo ponto apresentei três grandes paradigmas e mostrei a presença, em cada um deles, de uma dimensão valorativa e ética, além de uma concepção de ser humano, de social e de prática. Finalmente, numa terceira parte, fiz uma incursão um tanto complexa, tentando mostrar que pode-se entrever um novo paradigma, uma nova lógica que implica, na sua concepção, a ética. Além da identidade e da dialética de opostos que se digladiam, há uma dialética analética, onde o outro é visto numa relação de convivência e o mesmo se constrói a partir do olhar do outro.

Se a ABRAPSO nos oferece já possibilidades de se pensar esses novos paradigmas, muito temos de agir ainda para se poder instituir práticas que concretizem esse pensar. Desafios que nos esperam como pesquisadores, agentes do social, cidadãos e cidadãs de um novo Brasil que se anuncia.

\section{Referências}

ARISTÓTELES (1985). Ética a Nicômacos. In: M. da G. Kury (org), Brasília: Ed. da Universidade.

CNBB (Conferência Nacional dos Bispos do Brasil). (1994). Exigências éticas da ordem democrática. São Paulo: Paulinas.

DOS ANJOS, M. F. (1996). Apresentação. In: M. F. Dos Anjos e J. R. Lima Lopes (Ed.), Ética e Direito: um diálogo. (p.12) Aparecida, São Paulo: Ed. Santuário.

DUSSEL, E. (1977). Para uma Ética da Libertação Latino-Americana: II Eticidade e Moralidade. São Paulo: Loyola-Unimep.

DUSSEL, E. (1986). Ética Comunitária: Liberta o pobre! Petrópolis: Vozes. 
FARR, R. (1991). Individualism as a collective representation. In: V. Aesbicher, J. P. Dechonchy e M. Lipiansky. Idéologies et Représentations Sociales. ED.S.: Del Val.

GEUSS, R. (1988) Teoria Crítica - Habermas e a Escola de Frankfurt. Campinas: Papirus.

GUARESCHI, P. (2000) Sinais de um novo paradigma In: R. H. Campos e P. Guareschi (Orgs) Paradigmas em Psicologia Social - A perspectiva Latino-Americana. (p.207-221) Petrópolis: Vozes.

GUARESCHI, P. (1998) Alteridade e relação: Uma perspectiva crítica. In: A. Arruda (org.) Representando a Alteridade. (p.149-161) Petrópolis: Vozes.

GUARESCHI, P. A (1992) Emergência da consciência ética. Em: P. Guareschi e L.C Suzin (Ed.), Consciência Moral Emergente. Aparecida, São Paulo: Santuário.

ISRAEL J. (1972). Stipulations and Construction in the Social Sciences. Em: J. Israel e Tajfelh (Ed.), The Context of Social Psychology. (p.123-211) Londres: Academic Press.

KOHLBERG, L. (1966) Cognitive-Developmental Analysis of Children's Sex-role Concepts and Attitudes. In: E. E. Maccoby (Ed) The development of sex-differences. Stanford: Standord University Press,

. (1969). A Cognitive-Developmental Approach to Socialization. In: D. Goslin, (Ed.) Handbook of Socialization. Chicago: RandMcNallly.

LIMA LOPES, J. R. (1996). Ética e Direito — um panorama às vésperas do Século XXI. In: M. F. dos Anjos e J.R. Lima Lopes. (Ed.) Ética e Direito: um diálogo. Aparecida, SP: Santuário.

OLIVEIRA, M. A. (1996) Reviravolta Linguístico-Pragmática na filosofia contemporânea. São Paulo, Loyola.

PEGORARO, O. (1996). Ética é justiça. Petrópolis: Vozes.

PIAGET, J. (1932). The Moral Judgment of Child. Glencoe. Ill.: Free Press.

THOMPSON.J. B. (1995). Ideologia e cultura moderna: teoria social crítica na era dos meios de comunicação de massa. Petrópolis: Vozes.

\section{Ética e paradigmas: desafios da psicologia social contemporânea}

Rosane Neves da Silva

A criação de uma nova ordem mundial, de um mega-mercado planetário conhecido pela expressão "globalização" estabelece não apenas novas coordenadas nas relações espaço-temporais, em função da experimentação de novas tecnologias que desestabilizam uma tradicional noção de lugar e de tempo, mas, sobretudo, produz novos modos de valorização da própria experiência subjetiva em escala planetária. Com o intuito de promover uma expansão ilimitada do capital, eliminam-se as fronteiras (ao menos naqueles casos em que os interesses dos países que ditam as regras deste novo modelo não venham a ser atingidos) com a promessa de que assim estaria se produzindo a tão esperada "emancipação da humanidade". Na verdade, o termo "globalização" mascara todo um processo de aumento da violência e da miséria inerente à nova ordem do capitalismo mundial e responsável por sua expansão. Isto significa que a globalização, enquanto totalização planetária do modo de produção capitalista, afeta não apenas a produção de mercadorias num plano estritamente econômico, mas, principalmente, a própria produção de subjetividade na medida em que promove uma sistemática precarização da experiência subjetiva, já que a grande maioria da população mundial está longe de ter acesso e usufruir dos avanços científicos e tecnológicos que caracterizam esta nova ordem mundial.

Todas estas transformações da sociedade contemporânea colocam vários desafios para a psicologia social na atualidade. Talvez um dos principais desafios seja a necessidade de se estar constantemente reinventando novos modos de produção de conhecimento em função da própria complexidade das questões às quais nos vemos confrontados.

Se consideramos que o objeto da psicologia social são os modos de produção da experiência subjetiva, ou seja, o modo pelo qual um determinado conjunto de práticas sociais produz uma certa forma de relação consigo e com o mundo, podemos dizer que este objeto está em constante transformação e requer um questionamento permanente não apenas das

${ }^{1}$ Professora do Programa de Pós-Graduação em Psicologia Social e Institucional da UFRGS 
estratégias de conhecimento, mas, sobretudo, dos valores que norteiam nossas intervenções. Neste sentido, entendemos que a psicologia social contemporânea tem uma função eminentemente política que passa por realizar uma ontologia do presente e colocar em questão o que somos e qual é este mundo, este período no qual vivemos. É a partir desta dimensão política que gostaríamos de situar a relação entre ética e paradigmas, que é o tema deste encontro.

Vamos começar pela noção de paradigma. Para dar uma definição bastante abrangente, podemos dizer que todo paradigma refere-se a uma determinada estratégia de produção de conhecimento, socialmente compartilhada, na qual se atualizam: uma dimensão epistemológica (como conhecemos), uma dimensão ontológica (o que é isso a ser conhecido), uma dimensão metodológica (que ferramentas utilizamos nesta investigação) e uma dimensão ética (que valores conduzem nossas estratégias de produção do conhecimento). O paradigma, enquanto estratégia de produção de conhecimento, tem, portanto, uma função política, pois, ao atualizar estas diferentes dimensões epistemológica, ontológica, metodológica e ética, expressa um determinado processo de subjetivação.

Antes de prosseguirmos, é importante diferenciarmos os conceitos de subjetivação e de subjetividade. A subjetivação refere-se ao modo pelo qual se constituem determinadas formas de relação consigo e com o mundo em um contexto histórico específico. Cada formação histórica produz, portanto, uma experiência subjetiva singular definindo nossos modos de pensar, agir e sentir. De forma bastante sintética, tomaremos alguns exemplos para entender melhor este conceito. Segundo Foucault (1998), na Antiguidade clássica a subjetivação estava relacionada a um certo tipo de "cuidado de si" cujo procedimento não estava voltado para a busca de uma verdade interior ao sujeito, mas expressava uma relação imediata com o exterior, já que somente era digno de governar os outros aquele que tivesse um domínio sobre si. A subjetivação, neste caso, estava relacionada com aquilo que Foucault (1998, p.16) chama de uma "estética da existência", no sentido de fazer da vida uma obra de arte. Na Idade Média estas técnicas de si foram capturadas por um poder pastoral e transformadas num movimento introspectivo, cuja finalidade era a purificação dos pecados através de uma série de exercícios espirituais voltados para dentro de si. Hoje em dia, podemos dizer que os meios de comunicação de massa exercem este poder de captura sobre nossos modos de existência, definindo nossas escolhas e nossos gostos.

Já o conceito de subjetividade corresponde à criação de um determinado território existencial que não é nem fixo nem imutável, mas em constante processo de produção: estamos sempre construindo novos territórios e desmanchando aqueles que não dão mais conta da nossa experiência no mundo. Esta processualidade coloca em questão a ideia que tradicionalmente se tem a subjetividade como algo da ordem de uma interioridade e de uma suposta "natureza humana" e nos faz pensar a subjetividade como essencialmente fabricada e modelada pelo social, ou seja, fabricada e modelada pelos processos de subjetivação característicos de uma determinada formação histórica.

Segundo Guattari (1986), estes processos de subjetivação e, consequentemente, de produção de territórios existenciais (produção de subjetividade) podem oscilar entre dois extremos: ou produzindo uma relação de alienação - onde os valores estão voltados para um registro individual e narcísico (num culto de si voltado para o próprio corpo, para o próprio desejo a fim de encontrar 'dentro do eu' a sua própria razão de ser) - marcando aquilo que este autor chama de subjetivação capitalístico ${ }^{2}$ ou produzindo uma relação de criação — onde os valores estão voltados para a alteridade (num processo de invenção de novas coordenadas de produção subjetiva que decidam em favor da afirmação e da expansão da potência do outro) marcando o modo como podemos pensar os processos de subjetivação em uma perspectiva que Guattari (1992) chama de ético-estética.

Nosso objetivo nesta apresentação é mostrar o quanto os processos de subjetivação expressam determinados valores e que estes valores orientam nossos modos de existência e nossas estratégias de produção de conhecimento. Isso significa que ao falarmos de ética e paradigmas não estamos querendo estabelecer uma relação artificial entre dois termos

${ }^{2}$ O termo "capitalístico" foi forjado por Félix Guattari nos anos 70 para designar um modo de subjetivação que não se acha apenas ligado às sociedades ditas capitalistas, mas que caracteriza também as sociedades, até aquele momento, ditas socialistas, bem como as dos países do Terceiro Mundo, já que todas elas vivem numa espécie de dependência e contradependência do modelo capitalista. Por isso, do ponto de vista de uma economia subjetiva, não há diferença entre essas sociedades, pois elas reproduzem um mesmo tipo de investimento do desejo no campo social. 
distintos, mas sublinhar a relação de complementaridade e de pressuposição recíproca entre ambos. Não temos de um lado a ética e de outro um conjunto de paradigmas. Temos, isto sim, determinadas estratégias de produção de conhecimento (paradigmas) que expressam determinados valores que orientam nossos modos de existência (ética).

É importante assinalar que quando falamos de Ética não estamos utilizando esta expressão no sentido de uma Moral, ou seja, enquanto um conjunto de regras que prescrevem padrões de comportamento em termos do que é certo ou errado. A palavra Ética é utilizada aqui no sentido de um Éthos, ou seja, enquanto forma de habitar o mundo instaurando uma atitude de crítica permanente de nosso ser histórico e dos valores que conduzem nossas ações.

E neste sentido que falávamos anteriormente que a relação entre ética e paradigmas nos remete à discussão da própria função política da psicologia social contemporânea: trata-se de pensar o que somos e quais os valores que marcam a constituição histórica daquilo que hoje somos. Vimos que tais valores expressam um determinado modo de subjetivação e atravessam, inclusive, as próprias estratégias de produção de conhecimento. Isso significa que os paradigmas não são neutros nem inofensivos: eles são uma produção como outra qualquer.

A seguir falaremos das concepções e dos valores imanentes a dois paradigmas distintos - o paradigma cientificista tradicional e o novo paradigma ético-estético - e suas repercussões no campo da Psicologia Social.

O paradigma cientificista tradicional também pode ser chamado de paradigma arborescente (Gallo, 2002). Ele é baseado na ideia de Árvore, pois tende a buscar a raiz, a origem ou a filiação de algo, tentando assim encontrar o lugar da verdade. Tal paradigma propõe um sistema de interpretação capaz de compreender e descrever o mundo, definindo não só os problemas a serem investigados como os meios de se proceder a esta investigação. Sua principal característica é a fragmentação e a dispersão dos campos de conhecimento através de um movimento de hierarquização e multiplicação das especialidades.

O modo de conhecer o mundo é fundado na divisão (indivíduo $x$ sociedade; sujeito $x$ objeto; homem $x$ natureza) e na busca de uma regularidade do fenômeno estudado através de um processo de purificação tanto dos objetos a serem conhecidos como do próprio sujeito do conhecimento por meio de um apelo constante à "neutralidade".

Neste caso, sujeito e objeto são considerados como duas realidades distintas, "naturais" e que preexistem ao próprio conhecimento: existe, de um lado, um sujeito do conhecimento e, de outro, objetos estáveis sujeitos a leis universais. Por este motivo, é preciso garantir a regularidade dos fenômenos estudados através de instrumentos fidedignos que apreendam com exatidão aquilo que se quer conhecer.

Os valores que orientam as formas de agir no mundo acabam sendo escamoteados em nome dessa suposta "neutralidade".

Estas dicotomias-sujeito $x$ objeto - indivíduo $x$ sociedade; homem $x$ natureza - expressam uma tática de segmentação característica dos processos de subjetivação das sociedades capitalistas que visam assim garantir um controle mais efetivo sobre o tecido social em seu conjunto.

É no âmbito deste paradigma tradicional que a Psicologia vai poder se constituir no campo das ciências modernas. Se levarmos adiante nossa indagação, podemos dizer que a própria expressão "psicologia social" atualiza esta dicotomia inerente ao modo de subjetivação capitalístico: ela pressupõe que se aceita a separação entre indivíduo e sociedade como dois registros distintos, dilatando assim cada vez mais a experiência de uma subjetividade privatizada por meio de uma proliferação da ideia de indivíduo e de uma naturalização do próprio social. Em função dessa separação e inclusive para afirmá-la, a maior parte das teorizações no campo da psicologia social não cessa de fazer proliferar todo tipo de mediação entre estes dois registros (o que, em realidade, não faz senão aumentar a distância entre eles), construindo assim todo um campo de conhecimentos a partir de um problema mal colocado, ou seja, a partir dessa dicotomia que, como podemos constatar, não passa de um artifício de um determinado modo de subjetivação. É neste sentido que colocamos anteriormente que o objeto da psicologia social não é o estudo da interação entre indivíduo e sociedade, mas o modo como um determinado conjunto de práticas sociais produz uma certa forma de relação consigo e com o mundo, ou, dito de outra maneira, a forma pela qual um determinado modo de subjetivação produz certos territórios existenciais. 
No início desta apresentação vimos que as transformações da sociedade contemporânea colocam vários desafios para a psicologia social e que um destes desafios consistia exatamente em propor novas estratégias de produção do conhecimento. Mas para isso é preciso transitar, como diz Guattari (1992, p.24), de um paradigma cientificista para um paradigma ético-estético.

Neste novo paradigma ético-estético estas estratégias de produção do conhecimento estarão voltadas para identificar as formas de captura da subjetividade pelos modos de subjetivação dominantes. Isto se fará através de uma crítica permanente aos modos de valorização subjacentes à lógica capitalista que tende a embaralhar todos os códigos e a produzir uma equivalência generalizada entre todas as coisas.

Este novo paradigma também pode ser chamado de rizomático (Gallo, 2002), pois se encontra organizado a partir da ideia de Rizoma (Deleuze e Guattari, 1997). Ao contrário da árvore, o rizoma ramifica-se em múltiplas direções e cresce de acordo com as conexões que se realizam, passando, portanto, a ideia de aliança e não a de filiação. Trata-se de uma rede não hierárquica, que não tem começo nem fim; o rizoma encontra-se sempre no meio, entre as coisas, produzindo sempre novos e múltiplos agenciamentos.

Ao invés de propor uma fragmentação dos campos de conhecimento, este novo paradigma propõe um processo de experimentação capaz de criar novas coordenadas de leitura da realidade, produzindo assim uma ruptura permanente dos equilíbrios estabelecidos e recusando-se a se instalar no lugar da verdade. Sua principal característica é a desconstrução das hierarquias e das fronteiras que dividem os campos de conhecimento.

$\mathrm{Na}$ perspectiva de um paradigma ético-estético, conhecer é inventar um campo de problematização a partir de uma desnaturalização das dicotomias (indivíduo $x$ sociedade; sujeito $x$ objeto; homem $x$ natureza) e de uma recriação permanente do campo investigado.

Neste caso, sujeito e objeto não são tomados como realidades que preexistem à produção do conhecimento: o que vem antes é a relação, pois é ela que constitui os termos. Para tanto, é preciso garantir um coeficiente de transversalidade máximo entre os diferentes níveis e os diferentes sentidos de uma relação, tornando possível perceber as armadilhas do instituído e a naturalização das práticas sociais dominantes.
Nossa ação no mundo é orientada por valores de afirmação e expansão da potência do outro e visa à crítica permanente das formas de captura e assujeitamento da experiência subjetiva contemporânea.

Como vimos anteriormente, neste novo paradigma, a palavra Ética não fica reduzida à ideia de Moral, mas está relacionada a um modo de ser e habitar o mundo. Da mesma forma, a palavra Estética também não é tomada aqui em seu sentido habitual, circunscrita à ideia de belo ou reduzida a uma concepção que considera a Arte como uma mercadoria qualquer, institucionalizada e reificada. A palavra Estética é utilizada aqui para afirmar um campo de experimentação da subjetividade onde a Arte é tomada como expressão das formas de resistência e criação: resistência às formas de assujeitamento e dominação a que estamos submetidos e a que muitas vezes submetemos os outros, e criação permanente de novos modos de existência.

Esta dimensão ético-estética refere-se, portanto, aos valores que constituem nossas ações no mundo (o modo de conduzir-se e de habitar o mundo) e à recriação permanente de nossa própria existência como uma obra de arte.

Ao introduzirmos alguns elementos para pensar a relação entre ética e paradigmas em uma perspectiva ético-estética, buscamos problematizar os desafios da psicologia social na atualidade e contextualizar sua função política a fim de que nossa prática contribua para re-singularizar a experiência subjetiva em cima de novos valores.

\section{Referências}

Deleuze, G. e Guattari, F. (1997). Mil platôs - capitalismo e esquizofrenia. Vol. 1. São Paulo, Editora 34.

Foucault, M. (1998). O uso dos prazeres. ( $8^{a}$ edição). Rio de Janeiro, Graal.

Gallo, S. (2002). Conocimiento y transversalidad. Site da Internet: www.bu.edu/wcp/Papers/TKno/TKnoGall.htm

Guattari, F. e Rolnik, S. (1986). Micropolítica: cartografias do desejo. Petrópolis, Vozes.

Guattari, F. (1992). Caosmose: um novo paradigma estético. São Paulo, Editora 34. 


\section{Reflexões sobre pesquisa em psicologia, método(s) e "alguma" ética}

Andréa Vieira Zanella ${ }^{1}$

Vou começar essa fala resgatando alguns excertos de uma anedota que anda circulando nos endereços eletrônicos de quem navega pela internet, a qual considero preciosa para a discussão que aqui apresento:

A pergunta "por que o frango cruzou a estrada?", apresentam-se diferentes respostas, advindas de interlocutores variados espacial e temporalmente. Assim respondem:

Professora primária - Porque queria chegar do outro lado da estrada.

Poliana - Porque estava feliz.

Platão - Porque buscava alcançar o bem.

Aristóteles - É da natureza dos frangos cruzar a estrada.

Nelson Rodrigues - Porque viu sua cunhada, uma galinha sedutora, do outro lado.

Marx - $\mathrm{O}$ atual estágio das forças produtivas exigia uma nova classe de frangos, capazes de cruzarem a estrada.

Moisés - Uma voz vinda do céu bradou ao frango: "Cruza a estrada!" E o frango cruzou a estrada e todos se regozijaram.

Maquiavel - $\mathrm{O}$ frango cruzou a estrada. A quem importa o por quê? Estabelecido o fim de cruzar a estrada, é irrelevante discutir os meios que usou para isso.

Darwin - Ao longo de grandes períodos de tempo, os frangos têm sido selecionados naturalmente, de modo que, agora, têm uma predisposição genética a cruzarem estradas.

Einstein - Se o frango cruzou a estrada ou a estrada se moveu sob o frango, depende do ponto de vista. Tudo é relativo.

${ }^{1}$ Professora do Programa de Pós-Graduação em Psicologia da Universidade Federal de Santa Catarina (UFSC), Doutora em Psicologia da Educação pela Pontifícia Universidade Católica de São Paulo (PUCSP).
Kant - O frango seguiu apenas o imperativo categórico próprio dos frangos. É uma questão de razão prática.

ACM - Estava tentando fugir, mas já tenho um dossiê pronto, comprovando que aquele frango pertence a Jorge Amado. Quem o pegar vai ter que se ver comigo!

Sócrates - Tudo o que sei é que nada sei.

Dorival Caymmi - Eu acho (pausa)... - Amália, vai lá ver pra onde vai esse frango pra mim, minha filha, que o moço aqui tá querendo saber.

Trago essa anedota porque a considero ilustrativa do momento em que vivemos, mais especificamente no universo acadêmico. Uma das maiores conquistas da contemporaneidade, ${ }^{2}$ no que se refere à produção de conhecimentos reconhecidos como científicos, é a relativa dissolução de fronteiras entre áreas do saber demarcadas por um referencial hegemônico (e por que não dizer unívoco) de método.

A discussão sobre as diferenças entre as ciências exatas e as ciências humanas e sociais, a especificidade de seus objetos de estudo e caminhos possíveis para sua investigação, ocupa a arena do debate no circuito acadêmico mundial desde que a idade moderna no que tange à produção de conhecimentos se firmou. $\mathrm{O}$ estabelecimento de demarcadores claros do que pudesse vir a ser reconhecido como científico, pautados em uma lógica nomotético-quantificadora, difundiu-se como imperativo regulador de toda e qualquer investigação, independente de seus objetos e especificidades.

Em consequência, assistimos por um longo tempo, nas ciências humanas e sociais, à importação de modelos de investigação próprios das ciências exatas, os quais, se importantes na medida em que revelam facetas da realidade investigada, de modo algum esgotam essa mesma realidade e podem ser utilizados como únicas ferramentas para sua explicação. Trago

\footnotetext{
${ }^{2} \mathrm{O}$ conceito de contemporaneidade é utilizado aqui como sinônimo do momento em que se vive, apontado por Sawaia $(1997$, p.81) como "um momento histórico paradoxal, que apela à subjetividade e à identidade, ao mesmo tempo em que exclui o sujeito, configurando um processo social de inclusão do homem pela exclusão do sujeito, encoberto pelo apelo à subjetividade, à identidade e ao intimismo. Isto é, resgata-se o sujeito para instrumentalizá-lo e isolá-lo, condenando-o ao assujeitamento" (grifos da autora).
} 
aqui a fala de um físico brasileiro, Nelson Fiedler-Ferrara, que alerta para essa questão:

Não me parece correto imaginar-se que se está sendo automaticamente "científico" ao se utilizarem métodos e conceitos das ciências exatas em humanidades. Faze-lo, é verdade, pode enriquecer bastante a análise que se pretende, revelando novas nuanças e métodos de abordagem, mas a pertinência e consequências positivas dessa utilização devem ser demonstradas (Fiedler-Ferrara, 1998, p.45).

Chama a atenção, o autor, para a transposição direta de pressupostos de pesquisa entre áreas distintas do saber, desconsiderando-se especificidades e a compreensão de que qualquer fenômeno investigado é, fundamentalmente, complexo. Desse modo, produzir conhecimentos e validá-los cientificamente é tarefa que pressupõe, como ponto de partida, o reconhecimento tanto do recorte estabelecido como das condições de investigação enquanto necessários e delimitadores das respostas produzidas como as possíveis nesse momento histórico, com as ferramentas que se lançou mão e o olhar escolhido.

No que se refere à psicologia, o debate se apresenta de forma intensa sob polarizações que até pouco tempo tornavam impensáveis qualquer possibilidade de diálogo. Pesquisa quantitativa $x$ pesquisa qualitativa, pesquisa experimental $x$ outras pesquisas, pesquisa básica $x$ pesquisa aplicada, são algumas das expressões que revelam, mais que diferenças, intolerâncias e discursos que se prestam a exercícios de poder legitimadores de falsas cisões.

Sob a guarda de uma lógica iluminista, redentora, que poderia, via racionalidade instrumental, produzir e acumular conhecimentos que levassem à "libertação das irracionalidades do mito, da religião, da superstição, libertação do uso arbitrário do poder, bem como do lado sombrio da nossa própria natureza humana" (Harvey, 1993, p.23), foram padronizados e de certa forma universalizados os caminhos para toda e qualquer investigação em nome da ciência. Essa hegemonia, no entanto, vêm se revelando frágil e insustentável em um contexto social onde as intolerâncias não encontram guarida. Como isso se revela?

Embora incipiente em algumas "coletividades" científicas, mais visíveis em outras, assistimos hoje a uma abertura ao diálogo entre diferentes possibilidades de se conceber desenhos de métodos de pesquisa, sendo os resultados advindos dessas diferenças, analisados em razão do poder explicativo sobre a realidade investigada.

Essa abertura assenta-se fundamentalmente no reconhecimento do que Vygotsky já anunciava na década de 30 do século passado, a saber, que:

$\mathrm{O}$ objeto e o método de investigação mantém uma relação muito estreita... A elaboração do problema e do método se desenvolve conjuntamente, ainda que não de modo paralelo. A busca do método se converte em uma das tarefas de maior importância na investigação. O método, nesse caso, é ao mesmo tempo premissa e produto, ferramenta e resultado da investigação (Vygotsky, 1931/1995, p.47).

Esse pressuposto é reafirmado por vários pesquisadores contemporâneos, como Biasoli-Alves, que chama a atenção, quando da análise das estratégias de pesquisa, para "o acerto do método frente ao objeto e aos objetivos do projeto" (Biasoli-Alves, 1998, p.136).

Essa premissa é fundamental porque anuncia a abertura à diversidade, contrapondo-se ao modelo de ciência característico da modernidade que ainda brada em muitas instituições pela manutenção de sua posição hegemônica, modelo esse que se assenta, fundamentalmente, no pressuposto “do" método. Assim mesmo: singular, único, que se aplica a uma só possibilidade, distinto, excêntrico, notável, bizarro.

Vários são os sinônimos que o dicionário nos oferece para o que é único e, nessa condição, exclui o diverso, o heterogêneo, o dissonante, o plural. Conceber "o" método em ciência significa obliterar possibilidades de caminhos múltiplos na produção de conhecimentos, significa assentar as explicações possíveis sobre a realidade em uma premissa anterior que, de certo modo, direciona o olhar e cega o pesquisador para a multiplicidade de cores e luzes que compõem o fenômeno investigado.

Necessário aqui algumas explicações: certamente o olhar do pesquisador é jamais neutro, posto que sempre direcionado por alguns pressupostos. Com destaca Minayo,

(...) qualquer estudo da realidade, por mais objetivo que possa parecer, por mais 'ingênuo' ou 'simples' nas pretensões, tem a norteá-lo um arcabouço teórico que informa a escolha do objeto, todos os passos e resultados teóricos e práticos (Minayo, 2000, p.37). 
No entanto, a vertente até então hegemônica da pesquisa nega a existência desses pressupostos e se fecha, com essa postura, ao reconhecimento de que seu próprio olhar é datado, é social, é histórico. É, enfim, "uma" possibilidade. O que se olha assume, em consequência, caráter de verdade inexorável, sendo os dados advindos do caminho único, reconhecidos como expressão de toda a realidade, que ali se esgota. Apesar da crítica, é importante destacar que esses estudos apresentam, é certo, uma faceta da realidade, mas com certeza não a esgotam e sequer podem ser reconhecidas como seu correlato.

Abre-se assim o caminho para o acolhimento de olhares múltiplos que recobrem facetas, prismas e ângulos diferenciados. Abre-se assim a possibilidade do reconhecimento da realidade como complexa, contraditória, múltipla e em permanente transformação, bem como do pesquisador como constituído por essa realidade e que sobre ela se debruça, com foco em um aspecto e lentes que pode lançar mão naquele momento histórico, com as condições sociais e políticas em que se insere.

Nem tudo, no entanto, são flores. Afinal, o reconhecimento da diversidade, o acolhimento à diferença, caso não se paute em uma reflexão sobre $o$ que se acolhe, com que objetivo, assentado em qual projeto social e político, pode levar ao extremo de se calar diante da violência, da barbárie, do imponderável. Pode, enfim, significar aviltamento à vida, ao invés da sua afirmação.

Entro aqui com a reflexão sobre ética, ${ }^{3}$ ou melhor, sobre o necessário diálogo a ser entabulado pelos cientistas da relação entre ética e ciência. Afirmo a necessidade do compromisso dos pesquisadores, independente do objeto, dos objetivos e do método delineado em suas investigações, tanto com o que investigam - com os usos que serão feitos desses conhecimentos quanto com quem investigam.

${ }^{3}$ A discussão aqui apresentada parte do pressuposto que "Ética não se confunde com moral, como erroneamente as expressões consagradas 'ética católica', 'ética protestante', 'ética liberal', 'ética nazista', 'ética socialista'. Enquanto a moral tem uma base histórica, o estatuto da ética é teórico, corresponde a uma generalidade abstrata e formal. A ética estuda as morais e as moralidades, analisa as escolhas que os agentes fazem em situações concretas, verifica se as opções se conformam aos padrões sociais" (Srour, 1998, p.270).
Para discutir sobre o que se investiga, vou resgatar algumas afirmações, que considero ímpares, feitas por Cláudio Moura e Castro (1978) há mais de duas décadas. Ao discorrer sobre as vicissitudes do processo de elaboração de teses e dissertações acadêmicas, o autor destaca três critérios fundamentais para a escolha do tema da investigação: esta deve ser viável, original e relevante. A viabilidade é a primeira condição a ser considerada quando do desenho de uma pesquisa, pois propostas espetaculares podem correr o risco de ficar depositadas em fundos de gavetas ou hard disks caso o autor não tenha condições para realizá-la. Essas condições podem ser financeiras, de tempo, de acesso aos sujeitos com os quais se pretende trabalhar ou mesmo de material bibliográfico para a empreitada proposta. A originalidade, por sua vez, não decorre necessariamente do fato do objeto de pesquisa ser inédito, mas sim da capacidade que têm os resultados de nos surpreender. Por fim, ao falar sobre a relevância do tema de pesquisa e da necessária articulação com os demais critérios, o autor nos brinda com uma passagem que, dado ao seu caráter hilário e ao mesmo tempo deprimente para quem se preocupa com o impacto social e político do que se investiga, compartilho com vocês:

Foi realizada uma pesquisa que verificou que estudantes do sexo masculino tendem a carregar seus livros junto aos quadris, seguros por apenas uma das mãos. Já as mulheres levam-nos com ambas as mãos, cingidos junto ao peito. Original e viável essa pesquisa pode ser. Sua relevância, contudo, está por ser demonstrada. Não nos parece um tema prioritário na pesquisa educacional brasileira (Castro, 1978, p.315)

As escolhas dos objetos de pesquisa são, certamente, prerrogativas dos pesquisadores em sociedades democráticas e assim deve continuar sendo. No entanto, refletir e discutir sobre $o$ que se investiga, bem como sobre os resultados divulgados, é prerrogativa de todos, posto que interesses coletivos e financiamento público sempre estão envolvidos. O resultado da ciência é, sob esse prisma, ao mesmo tempo privado e coletivo, posto que a realidade em que se sustenta é produzida historicamente por todos, o que deveria significar o direito de acesso aos resultados de pesquisa e benefícios daí advindos.

O segundo aspecto que destaquei ao apontar a necessária relação entre ética e ciência diz respeito à com quem se pesquisa. Duas questões merecem 
consideração: falar em "com quem" demarca, necessariamente, uma postura epistemológica que considera a vinculação inexorável entre o sujeito que pesquisa e a realidade a ser apreendida. Esta vinculação não é, no meu entender, decorrente de unidades distintas que interagem em determinado momento, mas sim de mútua constituição, posto que aquilo que se investiga constitui de certo modo o olhar daquele que sobre ela se debruça.

Outra questão se refere à qualidade da relação estabelecida com esses sujeitos com os quais se trabalha. A Declaração de Helsinque, documento elaborado pela Associação Médica Mundial em 1964 que se apresenta como "referência ética mais importante para a regulamentação de pesquisas médicas envolvendo seres humanos" (World Medical Association apud Diniz \& Corrêa, 2001, p.681), é o parâmetro norteador para as reflexões que se faz sobre a relação "ética e ciência" em nível mundial. Genérica e sem qualquer pretensão normatizadora, a Declaração de Helsinque destaca, entre outros aspectos, que os sujeitos investigados sejam plenamente esclarecidos dos objetivos das pesquisas da qual participam. Mais ainda, é necessário que consintam, por escrito, em participar (consentimento pósinformado ou pós-esclarecido). Soma-se a isso o direito inalienável aos resultados obtidos, o que pode significar, em caso de pesquisas médicas, acesso ao que de mais avançado houver na área em termos de tratamento.

À primeira vista esses quesitos parecem obviedades, porém o movimento que se faz no sentido de modificá-la (vide Diniz \& Corrêa, 2001; Garrafa \& Prado, 2001), ou mesmo as poucas referências a esse respeito nas normas aos autores das publicações brasileiras na área médica (Sardenberg, Muller, Pereira, Oliveira, \& Hossne, 1999) denotam o quão distante estamos de sua universalização. Na esfera da psicologia a questão parece ainda mais precária, posto que consulta à base de dados Scielo, a partir das palavras chave ética, pesquisa e psicologia, resultou em ausência, em silêncio que, no meu entender, muito comunica. Estaríamos em uma esfera de saber que prescinde de pressupostos comuns em suas pesquisas, dispensando assim uma reflexão coletiva sobre ética? É mister que todos os pesquisadores "psi” são éticos? E que ética é essa?

O silêncio a esse respeito é preocupante. Afinal, se entendemos ética como fundamento filosófico e valorativo (Guareschi, 1998), não discutirmos que fundamentos são esses e em que se assentam, pode significar conivência com práticas investigativas que aviltam a dignidade humana. Somado ao discurso da diversidade, complexifica ainda mais a questão, posto que, como afirmado anteriormente, nem toda diferença merece consideração e reconhecimento.

Uma necessidade imperativa se apresenta, assim, para a consecução do diálogo necessário à legitimação de princípios éticos: o reconhecimento e acolhimento da diversidade na produção de conhecimentos precisa se fundar em princípios claros que se apresentem como norteadores de todo o processo, tanto no momento da definição de objetivos, quanto na coleta de informações e nas explicações produzidas.

Junto à defesa da clareza desses princípios apresento o que considero fundamental nas pesquisas psicológicas e sociais: o compromisso com a democratização dos bens materiais e simbólicos historicamente produzidos, o acolhimento à diferença, o compromisso com a "ética da vida justa" Afinal, nem tudo que se diz em nome da ciência pode ser aceito, sob o risco de se contribuir para práticas escusas e interesses privados avessos à emancipação do gênero humano.

Em síntese, poderia dizer que o compromisso social e político relacionado à pesquisa precisa ser pensado em três vertentes:

1. Em relação à realidade investigada - o compromisso é com a explicitação de seu movimento, sendo os resultados confiáveis no sentido de fiéis aos dados coletados e apresentados como o que foi possível naquele momento, com os procedimentos e lentes utilizadas, apresentá-la.

2. Em relação aos sujeitos investigados - Estão suficientemente esclarecidos dos objetivos da investigação da qual participam? Que retorno terão eles sobre o que foi investigado? Poderão se beneficiar desses conhecimentos? Em que medida?

3. Em relação à sociedade em geral - Que contribuição as reflexões produzidas apresentam para a transformação da realidade social em direção a modos de vida mais dignos e justos? Em que medida os resultados do que investigo contribuem para explicitar a realidade em seu contraditório e permanente movimento ao invés de camuflá-la?

\footnotetext{
${ }^{4}$ Vide Sawaia, 1997.
} 
Afirma-se, assim, que não há ciência neutra e sequer método neutro. Há uma coletividade de pesquisadores que necessariamente precisam enfrentar a árdua tarefa de encontrar pontos em comum. Esses pontos, por sua vez, não dependem de normas jurídicas para se afirmarem, embora no caso brasileiro tenhamos suporte suficiente para colocarmos a discussão em parâmetros minimamente aceitáveis. Estou me referindo ao Código de Ética Profissional dos psicólogos, do Conselho Federal de Psicologia, que em seu Art.30, "Das Comunicações Científicas e da Divulgação ao Público", afirma:

Art.30 - Ao Psicólogo, na realização de seus estudos e pesquisas, bem como no ensino e treinamento, é vedado:

a) desrespeitar a dignidade e a liberdade de pessoas ou grupos envolvidos em seus trabalhos;

b) promover atividades que envolvam qualquer espécie de risco ou prejuízo a seres humanos ou sofrimentos desnecessários para animais;

c) subordinar investigações a sectarismos que viciem o curso da pesquisa ou seus resultados;

d) conduzir pesquisas que interfiram na vida dos sujeitos, sem que estes tenham dado o seu livre consentimento para delas participar e sem que tenham sido informados de possíveis riscos a elas inerentes (Conselho Federal de Psicologia [CFP], 2002, p.16).

Os princípios reguladores do exercício profissional do pesquisador em psicologia coadunam, portanto, com as reflexões que venho tecendo neste momento. O Parágrafo Único desse mesmo artigo igualmente merece destaque, posto que vem ao encontro de uma vertente de análise aqui apresentada. Diz o seguinte:

Fica resguardado às pessoas envolvidas o direito de ter acesso aos resultados das pesquisas ou estudos, após seu encerramento, sempre que assim o desejarem (CFP, 2002, p.16).

Estamos muito bem servidos, portanto, o que se constata via consulta à regulamentação do exercício profissional em psicologia aqui exemplificado, em termos legais, ainda que esse documento não se revista de poder jurídico.

Por sua vez, mesmo que tivesse essa força, isso não garantiria legitimidade aos preceitos ali arrolados, posto que somente a difusão e universalização desses princípios é que garante a sua utilização como fundamentos de toda e qualquer ação dos profissionais psi, incluindo aí os pesquisadores da área.

Para caminharmos em direção à essa legitimidade, creio que precisamos superar antagonismos de partida, que nos cegam para o reconhecimento de aspectos importantes destacados por perspectivas teórico-metodológicas opostas. Urge que a comunidade científica em geral, e com maior ênfase da psicologia, resgate, na esfera da produção de conhecimentos que se pretendem científicos, reflexões sobre credibilidade, fidedignidade, validade, relevância e rigor, as quais servem de bandeira ao discurso de sustentação “do” método. Em contrapartida, os que defendem "os" métodos, os caminhos múltiplos e a polifonia que pode revelar a realidade enquanto diversa, trazem para o debate, além de alguns desses aspectos, a cara reflexão sobre o compromisso social e político do pesquisador e sua responsabilidade frente à sociedade que se quer produzir. Somente o cotejamento e consideração concomitante desses aspectos, em uma busca coletiva de informações sobre a realidade que permitam conhece-la e transformá-la, pode nos levar em direção a produção de conhecimentos em psicologia originais, viáveis e relevantes.

Para finalizar, voltemos à problemática do Frango que inaugurou esta conversa. Inicialmente cabe perguntar a quem interessaria saber porque o frango cruzou a estrada e (se há) qual a importância dessa questão. E original, certamente, mas não exatamente viável. Afinal, Menandro destaca, na direção dialógica que apontei acima, a

insuficiência da observação apenas da ação: é necessário ouvir explicações (e concepções subjacentes a elas) sobre os porquês admitidos da ação, da omissão, da recusa, do interesse, da associação, do afastamento (Menandro, 1998, p.399)

No caso da anedota apresentada, a resposta eticamente fiel à realidade só poderia, nesse sentido, ser dada pelo próprio frango, o que ainda não é possível na pesquisa científica, dada a impossibilidade de fala do galináceo ou da nossa de entender seus cacarejos.

Apresenta-se, assim, uma dificuldade que não podemos contornar, pois como trabalhamos na pesquisa social prioritariamente com pessoas, a resposta que poderíamos apresentar seria a proveniente do próprio sujeito com o qual se busca produzir conhecimentos, no caso o frango. 
Por sua vez, a fala do sujeito, para ser analisada, precisa de um referencial interpretativo que, no meu caso, buscaria investigar as dimensões públicas e privadas de sua fala. Isso significa analisar como o sujeito se posiciona perante a situação, suas possibilidades de compreensão da própria condição em que se encontra, as relações dessa sua prática tanto com o contexto imediato quanto com a trama de relações sociais características do momento social e histórico em que se vive.

A análise da resposta sustentar-se-ia, portanto, em informações do contexto atual, da história tanto dessa pessoa em particular quanto da coletividade em que se insere, com seus antagonismos, jogos de interesses, alianças e desconfianças, enfim, lutas cotidianas. Lutas essas que devagar apresentam resultados, como o que assistimos nesse memorável 27 de outubro de 2002, dia em que "a esperança venceu o medo" e pudemos nos apresentar com coragem e emoção, "sem medo de sermos felizes". E a primeira vez que paro diante da televisão e, com escancarada emoção e orgulho, escuto atentamente as palavras do nosso presidente Luís Inácio Lula da Silva. Não poderia deixar de compartilhar essa alegria com vocês, posto que significa, para mim, um importante passo rumo à concretização de uma ética da vida digna, solidária e justa.

\section{Referências}

BIASOLI-ALVES, Z. M. M. (1998). A pesquisa psicológica - análise de métodos e estratégias na construção de um conhecimento que se pretende científico. In G. Romanelli (Ed.), Diálogos metodológicos sobre práticas de pesquisa, (pp.135-157). Ribeirão Preto, SP: Legis Summa.

CASTRO, C. M. (1978). Memórias de um orientador de tese. In E. de O. Nunes (Ed.), A aventura sociológica: Objetividade, paixão, improviso e método na pesquisa social, (pp.307-326). Rio de Janeiro, RJ: Zahar.

CONSELHO FEDERAL DE PSICOLOGIA (2002). Código de Ética dos Psicólogos. Brasília, DF: Autor.

DINIZ, D, \& CORRÊA, M. (2001). Declaração de Helsinki: Relativismo e vulnerabilidade. Cadernos de Saúde Pública. 17 (3), 679-688.
FIEDLER-FERRARA, N. (1998). "Ciência, ética e solidariedade". In E. de A. Carvalho, M. C. de Almeida, N. N. Coelho, N. Fiedler-Ferrara \& E. Morin (Eds.), Ética, solidariedade e complexidade, (pp.29-47). São Paulo, SP: Palas Athena.

GARRAFA, V., \& PRADO, M. M. do (2001). Mudanças na Declaração de Helsinki: Fundamentalismo econômico, imperialismo ético e controle social. Cadernos de Saúde Pública, 17 (6), 1489-1496.

GUARESCHI, P. A. (1998). "Ética, justiça e direitos humanos". In C. M. B. Coimbra, H. B. C. Rodrigues, L. Camino, L. O. Palazzo \& P. Guareschi (Eds.), Psicologia, ética e direitos humanos (pp.9-19). Brasília, DF: Conselho Federal de Psicologia.

HARVEY, D. (1993). A condição pós-moderna: Uma pesquisa sobre as origens da mudança cultural. São Paulo, SP: Edições Loyola.

MENANDRO, P. R. M. (1998). “A curva generosa da compreensão: Temas em psicologia”. In I. Souza, M. F. Q. Freitas \& M. M. P. Rodrigues (Eds.), Psicologia: Reflexões (im)pertinentes (pp.397-417). São Paulo, SP: Casa do Psicólogo.

MINAYO, M.C.S. (2000). O desafio do conhecimento: Pesquisa qualitativa em saúde (7 ${ }^{\mathrm{a}}$ ed., pp.19-88). São Paulo, SP: Hucitec; Rio de Janeiro, RJ: Abrasco.

SARDENBERG, T., MULLER, S. S., PEREIRA, H. R., OLIVEIRA, R. A. de, \& HOSSNE, W. S. (1999). Análise dos aspectos éticos da pesquisa em seres humanos contidos nas Instruções aos Autores de 139 revistas científicas brasileiras. Revista da Associação Médica Brasileira, 45 (4), 295-302.

SAWAYA, B. B. (1997). O ofício da psicologia social à luz da ideia reguladora de sujeito: Da eficácia da ação à estética da existência. In A. V. Zanella, M. J. T. Siqueira, L. A. Lulhier, \& S. . Molon (Eds.), Psicologia e práticas sociais (pp.78-91). Porto Alegre, RS: ABRAPSOSUL.

SROUR, R. H. (1998). A ética nas organizações. In R. H. Srour. Poder, cultura e ética nas organizações ( $2^{\mathrm{a}}$ ed., pp.269-323). Rio de Janeiro, RJ: Campus. 
VYGOTSKY, L. S. (1995). "Método de investigación”. In L. S. Vygotsky. Obras escolhidas III: Problemas del desarollo de la psique (pp.4797). Madrid: Visor Distribuciones. (Trabalho original publicado em 1931).

\section{Identidade, subjetividade, alteridade e ética}

Neuza Maria de Fátima Guareschi ${ }^{1}$

Se adotarmos a perspectiva de que a ciência é uma prática social, isto significa dizer que a ciência é uma produção histórica e cultural que está permanentemente criando e recriando a si própria. Isto também quer dizer que a ciência não é absoluta e, portanto, não possui verdades, mas está continuamente em busca da compreensão do ser humano nos diferentes contextos que envolvem suas interações sociais.

Recentemente, emergiram na área da Psicologia Social enfoques teórico-metodológicos que vieram redimensionar a discussão, tanto em relação a questões epistemológicas, quanto em relação a aspectos da práxis da Psicologia Social.

O Construcionismo Social, por exemplo, vem marcar um diferente paradigma na Psicologia Social por incluir em seu corpo teórico e metodológico as práticas discursivas e a produção de sentidos no cotidiano, deve-se dizer que o Construcionismo Social inicia na Psicologia social uma virada linguística. ${ }^{2} \mathrm{O}$ Construcionismo Social $^{3}$ concebe tanto o sujeito quanto o objeto como construções histórico-sociais, estabelece uma crítica à ideia representacionista do conhecimento e da objetividade, problematizando aspectos sobre a realidade e o sujeito. É através de questões da linguagem, que o Construcionismo Social incorpora a perspectiva linguística do estruturalismo e a discussão das práticas discursivas e de discurso do pósestruturalismo nas análises sobre a produção de sentidos no cotidiano dentro da sua abordagem teórico-metodológica. Junto com o Construcionismo e o campo dos Estudos Culturais e as contribuições do pós-estruturalismo, principalmente através da obra de Foucault, é que queremos marcar e

${ }^{1}$ Professora Doutora do PPGP — Faculdade de Psicologia - PUCRS, Coordenadora do Grupo de Pesquisa: Estudos Culturais, Identidades/Diferenças e Teorias Contemporâneas.

${ }^{2}$ Ao fazer referência a Virada Linguística, cabe aludir o que Veiga-Neto (1996) propõe: "O que dizemos sobre as coisas nem são as próprias coisas (como imagina o pensamento mágico), nem são uma representação das coisas (como imagina o pensamento moderno); ao falarmos sobre as coisas nós as constituímos".

3 Para melhor compreensão sobre os pressupostos teóricos e metodológicos do Construcionismo Social consultar o trabalho organizado por Spink, 1999. 
problematizar os conceitos que são propostos por essa mesa, ou seja, Identidade, Subjetividade, Alteridade e Ética.

Os Estudos Culturais ${ }^{4}$ utilizam todos os campos que forem necessários para produzir o conhecimento exigido por um projeto particular. Dentro do ponto de vista teórico, um dos conceitos mais importantes para os Estudos Culturais é o de cultura. Hall (1980) afirma que dois passos estão envolvidos na nova formulação do sentido de cultura, considerado um dos grandes avanços dos Estudos Culturais. O primeiro é um movimento em direção a uma definição antropológica de cultura, como prática cultural. $\mathrm{O}$ segundo vai em direção a uma definição mais histórica de prática cultural, questionando o significado antropológico e sua universalidade por meio dos conceitos de formação social, relações de poder, dominação e regulação, resistência e luta.

Aqui a cultura é entendida tanto como uma forma de vida (ideias, atitudes, linguagens, práticas, instituições e estruturas de poder), quanto toda uma gama de práticas culturais (formas, textos, cânones, arquitetura, mercadorias produzidas em massa). Para Hall (1986) a cultura significa o terreno real, sólido, das práticas, representações, línguas e costumes de qualquer sociedade histórica específica. Mas também as formas contraditórias de senso comum que se enraizaram na vida popular e que produzem os modos de vida.

Uma das características dos Estudos Culturais é reconhecer a capacidade dos sujeitos sociais de manifestar diferentes práticas simbólicas. Sendo que estas estão situadas em um determinado contexto histórico. Para isto, é necessário descolar a ideia de cultura do âmbito da reprodução para uma posição onde a ação social é considerada de suma importância. Por esta razão que o objeto preferencial do campo dos Estudos Culturais se concentra no espaço popular, das práticas da vida cotidiana, relacionando-as com as relações de poder e posição política. Tendo em vista essa maneira de entender a cultura, não faz mais sentido o viés dicotômico entre alta cultura (música clássica, literatura dos grandes nomes, cinema de arte) e baixa cultura (música popular, literatura de folhetim, cinema popular, grafites).

${ }^{4}$ Outras discussões sobre o campo do conhecimento dos Estudos Culturais e seus enfoques teóricos e metodológicos podem ser encontradas nos seguintes trabalhos: ESCOSTEGUY, 2000; HALL, 1990; JOHNSON, 1986.
O ponto de referência intelectual a partir do qual os Estudos Culturais se lançaram foi o de

forçar-nos a repensar radicalmente a centralidade da cultura e a articulação entre os fatores materiais, culturais e simbólicos na análise social (HALL, 1997, p.32)

Assim, a "virada cultural" diz respeito à mudança de paradigma nas ciências sociais e humanas, cuja abordagem da análise social contemporânea passou a ver a cultura como uma condição constitutiva da vida social e não apenas um elo para o restante do sistema social. Este movimento teve início através de uma revolução em relação à linguagem, também chamada virada linguística.

A virada cultural vai ampliar essa visão de linguagem trazida pela virada Linguística para a vida social como um todo, enfatizando assim que a linguagem além de produzir aquilo que reconhecemos como realidade, ela também vai produzir os sujeitos dessa realidade.

As mudanças trazidas pela globalização envolvem a interação entre fatores econômicos e culturais, criando rápidas mudanças sociais, sérios deslocamentos culturais. A questão que se apresenta aqui é o quanto essas mudanças culturais globais abalam a vida local — o local não tem mais uma identidade objetiva fora de sua relação com o global — ou seja, uma tendência à homogeneização cultural. Essa aparente tendência pode ter como resultado um hibridismo, sintetizando elementos de ambas culturas em jogo, mas não sendo redutíveis a nenhuma delas, ou seja, o que chamamos de sociedades multiculturais.

\section{$\mathrm{O}$ que isto tem a ver com o tema proposto?}

Esse processo de globalização implica mudanças de sentidos, de marcadores identitários, de vetores de subjetivação, ou seja, uma multiplicidade que emerge a partir de condições criadas pela centralidade da cultura ao alcançar e se presentificar na esfera privada. Isto é, entra em nossos lares e modifica o modo como vivemos nele, modifica os sentidos e as práticas que constituem nossas vidas e os modos como nos conhecemos. Não é simplesmente a utilização de novas palavras para nomear objetos ou eventos como por exemplo "deletar", "placa-mãe", "backup". O computador tornou-se uma categoria conceitual e organizacional básica que resulta em uma consciência de posições de sujeito. 
As mudanças migratórias e tecnológicas modificam a relação com as esferas pública e privada: o privado tornou-se público através, por exemplo, dos programas de realities shows que mostram, mais do que os modos de viver, os modos como devemos viver. Mais do que experiências de vida, esses programas impõem também o modo como devemos experimentar a própria vida. Assim, a experiência que se faz de si, que é da esfera privada, torna-se da esfera pública, ao se publicizar através desses programas. Ou seja, marca os corpos, modifica o modo como nos conhecemos e nos posiciona como sujeitos. Ao mesmo tempo, os bens públicos, os bens "naturais", são tomados como bens privados, são privatizados, estabelecendo não apenas o acesso a eles, mas os modos de acesso a esses. Assim, a vida pública torna-se privada e, ao ser privatizada, estabelece também os modos como se vive na esfera pública. Isso tudo não diz respeito a uma inversão de valores e sim, à criação de novos valores, de novas práticas de significação, de novas formas de se pensar, de se reconhecer e de viver.

Poderíamos pensar, dessa forma, em uma homogeneização global, em um processo de "lisura" global, de uma obliteração de diferenças, de criações, de uma identidade mundial. Esse processo de globalização, junto às questões tecnológicas, mercadológicas e midiáticas, somadas às questões econômicas e políticas igualmente importantes, nos remete também ao conceito de identidade como fluídas ou não fixas, ou seja, que o sujeito assume diferentes posições.

Essas posições de sujeito, lugares que ocupamos, nos levam a analisar o conceito de identidade como não podendo ser mais pensada da forma antiga; uma identidade integral, originária, unificada ou possuidora de uma essência. E a subjetividade, como é entendida aqui, da mesma forma, são modos de subjetivação que se produzem a partir de um processo através das práticas de significação inseridas no contexto da cultura.

Essas transformações no conceito de identidade, dentre outras questões, nos leva a pensar sobre o descentramento característico do pensamento do sujeito pós-moderno, que suprime o sujeito transcendental e o retira do centro dos processos sociais. Segundo Veiga-Neto (2000), inspirado em Foucault, ao invés das práticas sociais, econômicas, culturais e políticas derivarem a partir do sujeito, é o sujeito que passa a se derivar a partir dessas práticas.
As identidades e os modos de subjetivação são produzidas no interior dessas práticas que são significadas pelos sujeitos e produzidas em locais históricos e institucionais específicos. Elas emergem no interior de relações específicas de poder e são mais um produto da marca da diferença, do que um signo de uma unidade idêntica. O processo da construção das identidades está sempre envolvido com a diferença, da relação com aquilo que não é, sempre referido ao outro: sou o que o outro não é.

Desta forma, é importante atentarmo-nos para esses movimentos que emergem dos processos de globalização, uma vez que esses acabam por mobilizar as diferenças. Isto é, não é o igual que vai produzir os sentidos, será a diferença que o fará. O que acontece globalmente são processos produzidos na articulação das diferenças culturais, das diferentes práticas de significação que não podem ser analisadas a partir de categorias, de narrativas supostamente originárias e iniciais, visto que se trata de entrelugares. Pode-se colocar esse entre-lugares como um terceiro espaço que se dá a partir de um movimento de hibridização cultural, o qual não se conceitua por uma síntese entre duas categorias iniciais, mas por um espaço de articulação das diferenças que "fornecem o terreno para a elaboração de estratégias de subjetivação — singular ou coletiva — que dão início a novos signos de identidade e, também, de espaços inovadores de colaboração e contestação no ato de definir a própria ideia de sociedade" (BHABHA, 1998, p.20). Ou seja, são as combinações e os deslocamentos de domínios da diferença que vão constituir um território de lutas e negociação de sentidos, nomeado de espaço da cultura.

Das lutas por imposições e negociações de sentidos, nesses espaços da cultura, nascem às políticas de identidades, movimentos sociais do qual ocupam-se alguns teóricos dos Estudos Culturais. As políticas de identidades ${ }^{5}$ surgem em um cenário em que se tenta impor a cultura como categorias universais, como sistemas de significação que pretendem expressar o humano e os grupos sociais, segundo categorias universais e naturais pré-estabelecidas, de acordo com critérios ditos como reais, como materiais, como anteriores à experiência que se faziam deles. As políticas

${ }^{5}$ Por Políticas de Identidade entende-se os processos dos grupos sociais e culturais de revolta contra a universalidade dos sentidos, produzida culturalmente pelos sistemas de significação que pretendem expressar o humano e o social em sua totalidade (GUARESCHI, 1999; 2000). 
de identidades são organizações de contestação que não se fazem pelo igual, mas pela diferença, não são lutas pela imposição da supremacia de uma identidade, constituem-se justamente na diferença, naquilo que não o são, não em termos materiais, mas em termos discursivos. Dito de outro modo, as políticas de identidades mobilizam-se nos espaços de articulação ${ }^{6}$ de sentidos, de práticas de significação, produzidas a partir da composição de determinadas formações discursivas, nas quais os sujeitos são posicionados e se reconhecem como sujeitos, não por aquilo que se identificam, mas por aquilo que identificam como diferença. Mas a diferença também não é tomada aqui como categoria universal e natural, a diferença, assim como as identidades, constituem-se em campos discursivos histórico e culturalmente contingentes e, portanto, edificações em determinados tempo-espaço.

As políticas de identidades são produzidas no interior de práticas de significação, por isso adquirem uma materialidade discursiva real, tornamse o real nos espaços de articulação, de hibridização de sentidos em que está em jogo uma multiplicidade de categorias referenciais que se fazem a todo o momento, marcando, instituindo e constituindo novas formas dos grupos sociais definirem a si próprios e serem definidos pelos outros. Não se trata, portanto, de um processo dialético no qual dois termos originais e antagônicos são combinados e sintetizados em um terceiro termo. Pelo contrário, referimos que os espaços de articulação, de hibridização, envolvem uma polifonia de sentidos que são produzidos quotidianamente $\mathrm{e}$ que implicam não no fortalecimento de uma ou outra identidade, mas na desestabilização contínua dos marcadores identitários pela produção contínua da diferença.

Portanto, não serão mais somente a família, a escola, a religião, a sexualidade, a raça, a classe social que determinarão os sentidos e, que ao mesmo tempo, darão a segurança e a estabilidade de supostos referenciais. A mídia, a ciência, as migrações também ocuparão esses lugares e com a rapidez com que produzem novos sentidos, constituirão permanentemente

${ }^{6}$ Para Hall (1996), a teoria da articulação "é a forma de conexão que pode fazer uma unidade de dois elementos diferentes, sob certas condições. É uma ligação que não é necessária, determinada, absoluta e essencial para todos os tempos. A assim chamada 'unidade' de um discurso é na realidade a articulação de elementos diferentes, distintos que podem ser articulados de modos diferentes porque não têm necessária pertença" (p.115). novas práticas de significação. Ao mesmo tempo em que determinados grupos sociais visam impor permanentemente práticas de significação particulares, os movimentos de contestação também serão permanentes. Como o próprio Foucault (1995) já alertava: “onde há poder, há resistências", mas essas resistências não são compreendidas como uma grande recusa, e sim como pontos que emergem em todo o tecido social. As políticas de identidades são tomadas, dessa forma, como movimentos de resistências e produtores de novos sentidos ao não se deixarem inscrever em determinadas posições de sujeito e, por determinadas posições de sujeito produzem novas posições, novas práticas de significação.

Como exemplo dessa discussão, é o movimento da teoria Queer. Essa teoria, nas elaborações que postula em referência aos estudos na área da homossexualidade, não busca uma espécie de marcadores identitários universais para uma nova condição de gênero. Não procura naturalizar a homossexualidade, mas sim desnaturalizar as relações de gênero e os próprios marcadores identitários que elegem formas normativas de ser homem e ser mulher. Longe disso, essa teoria emerge como um construto teórico que poderíamos considerar de pós-identitário, ou seja, para além de composições universalizáveis do sujeito. Mais do que poliprismática, a identidade desvanece em fluidez e instabilidade, promulgando que a história do "eu" é um constante reconfigurar-se, um devir.

Estas ideias são corroboradas com as ideias de Bhabha (1998) sobre os jogos de forças entre e no interior das práticas de significação, através de contestações e afiliações produzidos performativamente e que não devem ser analisadas como reflexos de traços culturais pré-estabelecidos. Neste caso, a articulação não é responsável por aquilo que somos, mas por aquilo que nos tornamos performaticamente em função de uma negociação complexa que confere autoridade aos hibridismos culturais, que acontecem em momentos de transformação histórica, que nos posicionam em zonas fronteiriças. O viver nas fronteiras nos torna sempre estrangeiros, experimentamos uma instabilidade e vulnerabilidade de sentidos ao cruzar novos territórios e quebrar barreiras. Podemos dizer que as sociedades atuais não têm um núcleo ou centro que produza identidades fixas, mas uma pluralidade de centros. Desta forma, os indivíduos vivem em diferentes contextos sociais e estão envolvidos em diferentes significados. Woodward (2000) fala das mudanças sociais em escala global, porém chama a atenção 
para essas mudanças mais a nível local e pessoal, onde essa complexidade atual exige que assumamos diferentes identidades, que são múltiplas e podem ser conflitivas. As identidades são diversas e mudam conforme nossas posições.

Assim, no que diz respeito a identidades, propomos uma ressignificação desse conceito de não o retomar como um princípio de substância e de eternamente igual a si mesmo, tampouco como fruto de uma determinada essência naturalmente dada, mas de que a identidade passe a ser constituída em uma rede discursiva e não em essências, querendo dizer com isso, que identidade não se trata de algo do sujeito, uma substância, mas como uma fixação em uma determinada posição na linguagem, constituída a partir da diferença, quer dizer, identidade e diferença são produtos do discurso, da cultura. Portanto, falamos de posição-de-sujeito, na qual a identidade expressa-se na forma como nos tornamos algo, ou alguém em uma determinada composição de grupo, etnia, raça, gênero, nacionalidade, família ou profissão.

O termo identidade nesta perspectiva teórica só se torna possível se pensado em relação à diferença, ou seja, identidade e diferença são tidas relacionalmente, de modo que só apreendemos um a partir do outro. Não é possível falar em alguma positividade do ser, sem relacioná-la ao que é da ordem deste não ser. A diferença não é o produto da identidade, mas tanto uma quanto à outra são resultantes de um processo (SILVA, 2000). Toda a identidade, por partir de uma positividade, tendencia-se a naturalizar, não obstante, a diferença produz um contra-movimento, desestabilizando as identidades.

Desta forma, o processo de construção das identidades sempre refere a um "outro", ou seja, "eu sou algo a partir daquilo que eu não sou", ou "eu não sou o que o outro é". Essa diferença é estabelecida pelo sujeito, como já dissemos, pelas Políticas de identidade, que são formas de problematizar as experiências de vida e de buscar reconhecer a produção de sentidos e, decorrente disso, a luta pela produção de sentidos que se imponham aos sentidos hegemônicos. Assim, as políticas de identidades procuram, então, compreender a complexidade e as contradições da produção dos estatutos identitários e, por conta disso, dos processos de subjetivação.
Ou seja, não basta o sujeito inscrever-se em uma rede discursiva, é necessário tornar essa inscrição uma maneira de constituição de um "si”, de um "dentro", pelo qual o sujeito se observa e se reconhece como tal. Melhor dito, não é suficiente ser interpelado e se identificar com determinadas marcas identitárias, é preciso dobrar isso sobre si mesmo; subjetivar-se. Nesse caso, assim como as identidades são o "outro" no exterior, a subjetivação é esse outro ser experimentado como um "outro em si mesmo", um estranhamento, uma perturbação e uma transformação de determinados modos de ser.

Para entender isso, foi preciso recorrer a condições históricas que possibilitaram compreender tanto as identidades quanto os processos de subjetivações como modos de problematizar a condição humana. Isso é dito porque os conceitos são entendidos como formações históricas e culturais que necessitam de um solo para serem pensados de uma determinada forma e não de outra.

As questões de cultura, de identidades (e aqui só podendo ser entendida pela alteridade) e de subjetivação, aqui discutidas, como um campo de conflitos e lutas, afasta-se da proposição de uma avaliação epistemológica de falso e verdadeira para enfatizar uma luta em torno da imposição e produção de novos sentidos e da construção de significados. Tal imposição acontece num plano que é sumamente significativo para a Psicologia Social, com repercussões nas intervenções mais variadas.

Desta forma, ao ressaltar a produção de sentidos através das formações discursivas propostas por Foucault (2000), objetiva-se determinados modos de ser e de se pensar constituídos culturalmente. Posto de outra forma, subjetividade não é o ser, mas os modos de ser. Subjetividade, nesta perspectiva, também não se trata de "algo que diz respeito ao indivíduo", algo da "subjetividade do sujeito", não se compõe como uma opinião pessoal, ou uma condição da individualidade. São modos pelo qual o sujeito se observa e se reconhece como um lugar de saber e de produção de verdade. Neste sentido, fala-se de processos de subjetivação por ser um produto cultural, melhor dito, por se fazer constantemente a partir de interpelações discursivas, ou seguindo as palavras de Foucault (1984), que denomina

de subjetivação o processo pelo qual se obtém a constituição de um sujeito, mais exatamente de uma subjetividade, que evidentemente é 
uma das possibilidades dadas de organização de uma consciência de si (p.137).

Ao colocarmos que a subjetivação é uma produção discursiva, tributária do social, da cultura, entende-se por tal processo a produção de modos de existência, que assim como não podem confundir-se com um sujeito, também sequer podem ser reduzidos à pessoa, pois é uma individuação particular ou coletiva que caracteriza um acontecimento (Deleuze, 1992). Isso quer dizer que, a subjetivação trata da formação de si através de procedimentos, empreendimentos, transformações, na nossa cultura, no modo como o sujeito faz a experiência de si mesmo em um jogo de verdades instituídas. E, assim como as identidades, os modos de subjetivação também se produzem a partir das relações que se estabelecem com o outro.

Gostaria de chamar a atenção, que a meu ver, a questão da ética dentro desta discussão está posta desde o início, porque falar em teorias ou conceitos implica falar em política e vice-versa. Em toda forma de entender o mundo, está implicada uma questão ética, as maneiras de se produzir conhecimento e o seu uso implicam em questões éticas. Mas, para finalizar, quero me remeter mais especificamente a questão da ética, exatamente pelas diferentes maneiras que podemos tomar, nos relacionar, nomear ou impor condições a esse outro, ou seja, a alteridade. Segundo Duschatzky e Skliar (2001) o outro pode ser tomado como fonte de todo mal, como sujeito pleno de um grupo cultural ou como alguém a tolerar.

A primeira, o outro como fonte de todo mal, implica em tomar as identidades como fixas, centradas, homogêneas, estáveis e implica em uma lógica de binarismos, ou seja, o que não é bom é mau; o que não é negro é branco; o que não é homem é mulher. Desta forma o que é diferente aos binários é o que não faz parte da maioria e a maioria é homogeneizada, pertence ao que é igual por ser idêntica. Dentro dessa lógica, o diferente passa a ser o depositário de todos os males ou falhas sociais: a pobreza é do pobre, a violência é do violento, o problema de aprendizagem, a deficiência, o deficiente, ou seja, a exclusão é do excluído, de tudo aquilo que não é posto como o igualou a maioria.

A segunda, o outro como sujeito pleno de uma marca cultural, de acordo com Duschatzky e Skliar (2001), indica a concepção que as diferenças culturais, a diversidade são absolutas e que as identidades se constroem em únicos referenciais, sejam étnicos, de gênero, de raça, de classe social entre outros.

A radicalização desta postura levaria a exagerar a identidade do outro ou a encerrá-la em pura diferença. Desse modo, permaneceriam invisíveis as relações de poder e conflito e se dissolveriam os laços de vinculação entre sujeitos e grupos sociais (Duschatzky e Skliar, 2001, p.128)

Portanto, isso nos faz ficarmos atentos ao multiculturalismo, pois este deve ser sempre criticado ou questionado para que não se restrinja somente a perspectiva cultural, mas que esteja aberto para perceber outras questões sobre políticas de identidade e de pensamentos. Assim, evitará de se tornar mais um discurso hegemônico ou limitado quando se tratar de discutir sobre as diferenças em suas pluralidades de articulações, ou seja, o multiculturalismo conservador abusa da diversidade para encobrir uma ideologia de assimilação.

Não podemos entender o sujeito somente na sua diferença ou colocar a diferença como limite de sua identidade.

A terceira, o outro como alguém a tolerar, implica em não confrontar a tolerância ou que ela está isenta de ambiguidades e o medo ao relativismo. Segundo Duschatzky e Skliar (2001, p.134) podemos reconhecer a tolerância de duas formas: "a assimilação individual e o reconhecimento do grupo" ou seja:

As culturas não são essências, identidades fechadas que permanecem através dos tempos, mas são lugares de sentido e de controle que podem alterar-se e ampliar-se em suas diferentes interações. Algumas culturas podem ser excludentes. Desta forma a tolerância pode debilitar a capacidade de perceber as diferenças discursivas e mascarar as desigualdades. (Duschatzky e Skliar, 2001, p.135)

Esses autores ressaltam ainda, que o mesmo referencial teórico ressalta que a tolerância pode não colocar em questão os modelos de exclusão,

tem uma grande familiaridade com a indiferença, corre o risco de se transformar num pensamento de desmemória e até materializar a morte do diálogo. (p.136)

Assim a ética, dentro dessa discussão da produção de identidades e modos de subjetivação a partir da alteridade, pode ser pensada em não 
tomar o outro como fonte de todo mal que é, o que nos impele ao sexismo, machismo, racismo e homofobia, que o discurso do multiculturalismo corre o risco de fixar os sujeitos em uma identidade única e condená-los a não ser outra coisa senão aquilo que é e, por último,

a tolerância pode nos instalar na indiferença e em um pensamento frágil diante a compreensão dos sujeitos que é o grande trabalho da Psicologia. (Duschatzky e Skliar, 2001, p.137)

Referências

BHABHA, H. (1998) O local da cultura. Belo Horizonte: Ed. UFMG.

DELEUZE, G. (1992) Conversações. Rio de Janeiro: Ed. 34.

ESCOSTEGUY, A. C. (2000) Estudos Culturais: uma introdução. In: Da Silva, I. I. (org.) O que é, afinal, Estudos Culturais? Belo Horizonte: Autêntica.

FOUCAULT, M. (1995) “O sujeito e o poder.” In: Dreyfus, H. E. Rabinow, P. Michel Foucault - uma trajetória filosófica: para além do estruturalismo e da hermenêutica. Rio de Janeiro: Forense Universitária, p.231-249.

(2000) Arqueologia do Saber. Rio de Janeiro: Forense Universitária.

. (1984) Psicologia e Doença Mental. Rio de Janeiro: Tempo Brasileiro.

GUARESCHI, N. (1999) "Políticas de Identidade: uma breve concepção". Educação (PUC/RS), Porto Alegre, v. 39, p.7-26.

. (2000) Políticas de Identidade: novos enfoques e novos desafios para a Psicologia Social. Psicologia e Sociedade, São Paulo, v. 12, p.110124.

HALL, S. (1980) "Cultural Studies and the Centre: some problematics and problems.” In: Hall, S., Hobson, D., Lowe, A., E Willis, P. Culture, media, language - working papers in cultural studies, 1972-1979. Londres: Routledge e Centre for Contemporary Cultural Studies/University of Birmingham.
(1986) "Gramsci's relevance for the study of race and ethnicity". Journal of Communication Inquiry, 10 (2), p.5-27.

. (1996) "The problem of ideology: marxism without guarantees". In: David, M E Chen, K.H. Stuart Hall: critical dialogues. Routledge: London and New York, 1996.

(1997) "A centralidade da cultura: notas sobre as revoluções do nosso tempo". Educação \& Realidade. Porto Alegre: UFRGS/FACED, v.22, n.2, jul/dez, p.5-46.

JOHNSON, R. (1986) "The story so far: And further transformations". In. D. Punter (org.). Introduction to Contemporary Cultural Studies. Londres, Longman.

SPINK, M. J. (Org.) (1999) Práticas discursiva e produção de sentidos no cotidiano. São Paulo: Cortez.

SILVA, Thomaz (org.). (2000) Identidade e diferença: a perspectiva dos Estudos Culturais. Petrópolis: Vozes.

VEIGA-NETO, A. (2000) "Michel Foucault e os Estudos Culturais". In: Costa, M. Estudos Culturais em educação: mídia, arquitetura, brinquedo, biologia, literatura, cinema... Porto Alegre: Ed. Universidade/UFRGS, p.37-69.

(1996) Olhares... In: Costa, M. V. (org.) Caminhos Investigativos. Porto Alegre: Editora Mediação.

WOODWARD, K. (2000) Identidade e diferença: uma introdução teórica e conceitual. In: Silva, Thomaz (org.). Identidade $e$ diferença: a perspectiva dos Estudos Culturais. Petrópolis: Vozes. 


\section{Da subjetividade sob sofrimento narcísico numa cultura da banalidade do mal: abordagem ético-política do sofrimento humano}

Angela Maria Pires Caniato ${ }^{1}$

Mi amor es para mi algo muy precioso, que no tengo derecho a derrochar insensatamente. Me impone obligaciones que debo estar dispuesto a cumplir con sacrificios. Si amo a alguien, es preciso que éste lo merezca por cualquier titulo. (...) Merecería mi amor si se me asemejara en aspectos importantes, a punto tal que pudiera amar en él a mi mismo; lo merecería si fuera más perfecto de lo que yo soy, en tal medida que pudiera amar en él al ideal de mi persona; debería amarlo si fuera el hijo de mi amigo, pues el dolor de éste, si algún malle sucediera, también seria mi dolor, yo tendría que compartirlo. En cambio, si me fuera extraño y se no me atrajese ninguno de sus propios valores, ninguno importancia que hubiera adquirido para mi vida afectiva, entonces me seria muy difícil amarlo. Hasta seria injusto si lo amara, pues los míos aprecian mi amor como una demostración de preferencia, y les haría injusticia si los equiparase com un extraño (Freud, 1981, p.3044).

As reflexões aqui enunciadas poderão se entendidas como o caminhar de preocupações clínicas no processo de construção das subjetividades enquanto atravessadas pelas vicissitudes do viver em determinada ordem social e sob cuja égide se organiza a produção do conhecimento.

Quando se constata que vem sendo mantida a fragmentação da teoria e da prática psicológicas em áreas distintas entre si no decorrer da construção da história da Psicologia no Brasil, quando se institucionaliza esta privatização-prisão do conhecimento "psi" e quando esta compartimentalização se oficializa em especialidades profissionais, eu me identifico entre aqueles poucos ditos psicólogos clínicos que vem tentando pensar contextualmente as questões da subjetividade - a partir de uma compreensão freudomarxista do homem como ser eminentemente social.

O objeto de estudo neste texto - o sofrimento humano - será abordado a partir da compreensão de Freud em El Malestar en La Cultura (1981), identificando na contemporaneidade algumas das mazelas vividas

\footnotetext{
${ }^{1}$ Professora da Universidade Estadual do Maringá-PR
}

pelos sujeitos em suas relações com a cultura. A cultura é aqui examinada a partir de expressões de certas formas de ordenação social sob as quais as subjetividades estão vulnerabilizadas, essencialmente, constituindo-se em expressões mais ou menos sutis de violência social, cujos estragos nos homens se manifestam quando esta violência é internalizada pelos sujeitos (sentimento inconsciente de culpabilização) e como tal, passam a gerir as formas de relações entre os indivíduos. Por outro lado, buscaremos em Theodor Adorno (1985), em seu conceito de indústria cultural, a mediação entre a subjetividade e a cultura para penetrando no mundo interno dos sujeitos detectar os processo subjetivos desencadeados pela internalização das ideologias societárias, de caráter essencialmente violentador, tendo em vista suas funções de ordenar e manter um status quo autoritário.

Este estudo constitui-se num aprofundamento na compreensão da subjetividade sob violência social que venho desenvolvendo desde minha tese de doutorado - A história negada. Violência e cidadania sob um enfoque psicopolítico (1995) na qual meus sujeitos foram ex-presos políticos da Ditadura Militar de 1964. O tema da violência social conduzente ao sofrimento humano vem sendo objeto de pesquisa em projetos de iniciação científica (PIBIC/CNPq), tais como expresso no artigo intitulado Matrizes psicossociais do sofrimento humano na contemporaneidade (2002), que foi produzido por uma de minhas orientandas, acadêmica de Psicologia, Michele Aparecida de Castro e no de outras orientandas, a também acadêmica Laura Hauser e a doutoranda Regina Perez Christofolli Abeche apresentado no III Encontro Latinoamericano dos Estados Gerais da Psicanálise que realizou-se em Buenos Aires em novembro de 2002: É hora do espetáculo da perversidade: o aprisionamento da subjetividade dentro do reality shows.

Espero vir a ser evidenciada, nas reflexões que se seguem, a tensão dialética entre a subjetividade e a cultura e ir, de forma despretensiosa, ficando esclarecida que a abordagem da subjetividade aqui examinada, está respaldada nos conceitos psicanalíticos de identificações projetiva e introjetiva, assim como na compreensão freudiana do sentimento de culpabilização inconsciente por ingerência da violência social internalizada. Espero estar deixando desqualificada qualquer pretensão dogmática e/ou de má fé de atribuição de pura imanência às injunções necessariamente presentes, do instinto de morte que aqui não serão 
tratadas de forma naturalizada e descontextualizada (Freud, S., El Malestar de La Cultura, 1981).

O caminhar pela dialética subjetividade-cultura na apreensão da violência social internalizada

Pretendo, ainda, neste processo de compreensão do sofrimento/ felicidade humanos estar conseguindo aproveitar os ensinamentos de um número cada vez maior de psicanalistas, que refletem a partir da perspectiva relacional e social dos seres humanos. Agora reporto-me a René Kaës (1991):

Freud ao deslocar com acerto o acento sobre a fantasia nunca abandonou porém, a ideia da historicidade dos acontecimentos e seu destino na vida psíquica. (...) [Muito ao contrário, a omissão da história pelos psicanalistas conduz a um] enfoque que levará o analista a se tornar cúmplice de um segundo assassinato ao trazer sobre a cena de fantasia a cena da história, sem identificar corretamente a matriz psíquica e/ou social da violência (p.140-141).

A minha inserção na psicopolítica da Teoria Crítica de Theodor Adorno vem sustentando o esforço e a tenacidade para romper esta cisão do e no homem por entendê-lo como intrinsecamente uno. Minhas indagações, preocupações, sistematizações teóricas hão de ser entendidas sem esquecer que sou formada em Psicologia. Desde a graduação venho recebendo formação psicanalítica que vem sofrendo rupturas importantes e reorganizações significativas a partir não só da pratica clínica e acadêmica como também por estar atenta e receptiva ao que a minha vivência cotidiana vem me permitindo ter acesso, antepondo-se dúvidas que me exigem prontidão e reflexão discriminatórias. Preocupo-me, portanto, com a compreensão da subjetividade na busca das vivências internas dos sujeitos e não de uma simples explicação racional de suas vidas. Se há uma racionalidade a ser buscada no plano subjetivo dos indivíduos não é, com certeza, a racionalidade dos atos conscientes e voluntários, ou melhor, daqueles da premeditação das ações. Estou buscando aquelas ações que, mesmo partindo dos sujeitos, estão determinadas não só por atos deliberados da consciência, mas que são passíveis de motivação da ordem inconsciente e que sofrem interferência das ideologias societárias irracionais, dos hábitos e costumes culturais de uma sociedade autoritária, violenta, excludente e injusta.
Como diz Iray Carone (1991):

A Psicologia Política partiu da premissa segundo a qual subjetividade e a sociedade enquanto polaridades históricas se remetem reciprocamente. Abstrair uma polaridade da outra, portanto, é não atingir a compreensão do processo político na sua totalidade, porquanto o sujeito e o objeto são mediados reciprocamente. $\mathrm{Na}$ medida em que a tensão dialética for mantida na análise dos fatos e processos políticos, não haverá riscos de psicologizá-los ou de 'objetivá-los' pelas categorias econômicas (p.113).

O conceito de indústria cultural de Adorno (1985) e a revisão da Psicanálise feita por ele e alguns frankfurtianos na obra Teoria Critica Del Sujeito... (1986) me ensinaram que

a ideologia além de ser um processo formador de consciência e não apenas instalado nela, opera no nível do inconsciente, no sentido forte do termo: ela não apenas oculta dados da realidade, mas os reprime, deixando-os sempre prontos a retomar à consciência, ainda que de novo sob formas ideológicas. Nessas condições, o desenvolvimento da consciência pelo contato reflexivo com a realidade é um processo doloroso, como é a própria civilização na concepção freudiana. Trata-se de um processo difícil de ser suportado por pessoas cuja estrutura de personalidade foi moldada para reproduzir a heteronomia e para fugir do esforço de defrontar-se com a diferença e com o novo (Cohn, apud Caniato, 1995, 253).

Situando um pouco mais as enunciações acima, reporto-me aos ensinamentos de Iray Carone (1991) para afirmar que

as ideologias são determinadas societariamente mas os sistemas ideológicos do sujeito (opiniões, atitudes e valores) são organizados por motivações irracionais, cuja organização, por sua vez, são estruturas psíquicas, mais ou menos estáveis. Uma coisa é a ideologia enquanto fenômeno social e outra, a sua internalização e fixação na estrutura de personalidade do sujeito. As ditas "opções ideológicas" do sujeito têm razões que a própria razão desconhece (p.115).

Por outro lado, entendo que a especificidade do existir humano está orientada para a tarefa histórica na qual sua práxis carrega o compromissodever de construir sua vida em sociedade buscando a felicidade individual e coletiva. É sua missão ser sujeito e forjar a proteção e o amparo para si e para os outros semelhantes por meio de instituições que lhe permitam o 
acolhimento de si e dos outros diferentes dele, evitando, no que the for possível, o sofrimento e o adoecer psicossocial (Freud, El Malestar en La Cultura, 1981).

Não há dúvida que esta perspectiva de trabalho reflete princípios éticos utópicos por que o desenvolvimento histórico das relações entre os homens aponta para a intensificação da violência social (Bauman, 1998) e para o desenraizamento dos homens de sua comunidade humana (Arendt, 1978). As ciências e, em especial a Psicologia, não puderam cumprir a promessa de conduzir o homem para a felicidade (Sawaia, 1995).

O culto à imanência psíquica — "visão de avestruz" - (Caniato, 1999) prevalece na teorização e prática da Psicologia Clínica, impedindo aos profissionais de poderem cooperar com seus clientes na apreensão de condições reais de vida como disruptivas e perversas, consequentemente, mantendo-os paralisados e impotentes para ações defensivas eficientes e/ou transformadoras das expressões de desamparo, da indigência e da opressão mutiladora a que cada um e todos estão expostos.

Não é aqui o momento de aprofundar na análise desta matriz epistemológica mas é o de constatar que, além do intimismo psíquico e seus desdobramentos no isolacionismo, na negação da alteridade e na impossibilidade de troca entre indivíduos diferentes (Mendolowics, 2001), tal perspectiva está iluminada e atravessada por teorizações acumuladas pelas diferentes áreas na produção "psi" (Figueiredo, 1995) que vem gerando práticas que desembocam em sérias implicações de natureza éticopolítica muitas já identificadas pela Psicologia Política e por pensadores na Psicanálise (Vianna, 1994). Certamente, as intervenções embebidas em teorizações que negligenciam na identificação e análise dos determinantes disruptivos de natureza social na estruturação das subjetividades (Adorno, 1986a; Guinsberg, 2001) vem ratificando o agravamento das condições concretas do viver humano sem sequer ser identificada a exigência de integridade psicossocial para que os homens exerçam sua condição de sujeitos históricos e efetivem as mudanças nas instituições culturais e na ordenação social que viabilizem a preservação da vida humana (Mariotti, 2000). Isto porque na contemporaneidade, não há dúvidas que é o capital o grande Senhor da sociedade (Carone, 1991).
Apenas para servir de fundamento às assertivas apontadas anteriormente, pode-se nomear a forma por meio do qual a contribuição ingênua e/ou intencional de psicólogos vem sendo apropriada e posta a serviço de uma certa cultura de massa tornada palco de relações sociais opressoras e excludentes na sociedade globalizada na contemporaneidade (Matin \& Schumann, 1999). Respaldada no apogeu da fetichização do consumo de massa que não mede esforços na malversação da tecnologia (Sennett, 2001), reiteradamente vem se promovendo a desvalorização de vida humana, justificada pelo fatalismo alienante e alienador atribuído aos povos oprimidos, conforme nos alerta Martín Baró (1987 e 1989).

Sob esse pano de fundo inexiste qualquer pudor no uso da ciência psicológica colocada a serviço da culpabilização e criminilização de indivíduos, de grupos e até povos (Dejours, 2000; Caniato, 2000) para assim justificar e legitimar o extermínio de grande parte da humanidade, empurrada para a exclusão e para a miséria (Bauman, 1999) e/ou destruída por espetáculos esplendorosos e respandecentes de bombas, mísseis e outros artefatos bélicos (Chomsky, 2002). Desavergonhadamente e sob a égide de uma moralidade técnica (Bauman, 1998) a mídia acompanha, enaltece e legitima tais ações sob o manto de uma suposta prevalência do bem sobre o mal. Joga os pares numa carnificina fratricida sob a indiferença e o consentimento de muitos com a barbárie que se expraia para além da tela midiática, consubstanciando-se em valores que passam a ordenar a vida entre os homens, porém tidas como expressão naturalizada para uma normatização perversa da convivência social.

Tais ações beligerantes já não causam mais comoção ou indignação e, sim, indiferença tanto aos ofensores como aos ofendidos. Porém, mesmo assim banalizadas, não deixam de disseminar o horror, mesmo que de forma inconsciente, nas relações entre homens quando se implanta no âmago da subjetividade dos sujeitos assim tornados cúmplices de tais ações disruptivas.

O holocausto e a barbárie persistem sob formas mais invisíveis da violência (Dejours, 1999) incorporando-se em práticas sociais veladas de crueldade - cultura da mortificação - (Ulloa, 2001a) da qual não vem escapando as formas de atuação das organizações sindicais e de grupos que se dizem representantes de certa esquerda revolucionária, conforme vários autores e, entre eles Frei Betto (2002) nos ajudam a entender. Para terminar este parágrafo, pleno de brutalidades, vamos nos aliviar na poesia e escutar 
o que nos diz o psicanalista Ulloa (2001b): "La crueldad suele generarse a partir del fracaso de otro dispositivo, también cultural, el de la ternura" (p.1).

$\mathrm{Na}$ era da avareza (Mariotti, 2000), a dicotomização dos homens entre aqueles que são portadores do bem e os outros que atemorizam por serem detentores do mal (terroristas) ganha dimensões mundiais e encobre a ganância pelo dinheiro tornado fetiche para encontrar e justificar atos bélicos e estes, sim, dos verdadeiros terroristas, legitimados em nome da defesa e da proteção da humanidade (Chomsky, 2002). Por outro lado, a complacência coletiva e a indiferença de indivíduos e grupos diante desta perversa crueldade, que atravessa as relações entre os homens, apoia-se na apatia de todos que, como se sabe, está embebida no ódio que se alastra sorrateiramente por todo o tecido social. Este processo relacional só se vem tornando possível porque sustentado na/pela banalização do mal (Arendt, 2000). Acrescente-se a esta forma de valoração social da violência a permissão para destruir, sem culpa, que é facilitada e ampliada pela distância permitida pela tecnologia. Os atores sociais ficam isentos da responsabilidade por atos de violência e até mortais cometidos por eles porque não participam diretamente dos seus efeitos. Até que as brigas de gangs pela Internet desemboquem nos espaços urbanos, enquanto não ocorrem os confrontos diretos, agressores e agredidos permanecem tranquilamente por detrás das telas dos computadores. Enquanto alguns poucos não chegam nos campos de batalha para fincar a bandeira da vitória, as mortes ocorrem aos milhares nos espaços geográficos selecionados para detonar artefatos bélicos com uma simples compressão de uma tecla que, com perfeita precisão e acuidade aciona miríades de mísseis e bombas. Os tratados internacionais para proteção de civis quando determinado Estado entra em guerra vem sendo desrespeitados em nome de "erro técnico". Esta facilitação técnica na ordenação social para ampliar/difundir a violência e a barbárie sem a culpa individual e/ou social, Bauman (1998) chama de moralidade técnica. A vida em sociedade cada vez mais está ordenada pelas regras abstratas e hierárquicas da burocracia na qual se dissolve e esvazia a atribuição de autoridade que, tornada impalpável e não-individualizada, constrói a impunidade como alicerce distributivo de privilégio e sanções (Bauman, 1998; Caniato, 1999).

O espetáculo da perversidade no qual se constrói o sofrimento pelo aprisionamento da subjetividade (Abeche et al., 2002) não termina na mídia e há de ser analisado na inversão ideológica que banaliza a violência e torna sagrado o consumo, mas que para tal, instala a vigilância e o confinamento de todos e entre todos, indiscriminadamente controlados e punidos. A lógica amigo/inimigo se instaura sob a desconfiança que todos são forçados a nela viver para estratégica e sedutoramente entrar no "palco" para exibirse sob glamour e deixar-se esvaziar de tudo o que é seu, à priori contaminado pela suspeição. Esta perversa inversão ideológica destrói a vida coletiva solidária que é substituída pela complacência à malignidade, atribuída a certos indivíduos, grupos e/ou povos. Parece não haver mais um oásis de refúgio a não ser o voltar-se para o foro íntimo que já é morada desta brutal violência internalizada. É impressionante como diferentes arranjos destas atribuições sociais de periculosidade são incorporadas pelos indivíduos (Coimbra, 2001), não para serem usadas em reações defensivas de si e de seus pares diante da opressão e violência sociais vividas. Tais atribuições incorporam-se e substituem as suas identidades originais que sucumbem. Os sujeitos perdem a capacidade de identificar as reais fontes de perigo, de ameaça e violência sociais quando começam a se digladiar entre seus pares. Não conseguem sustentar certa indignação que os pudesse conduzir a repudiar e rechaçar tais atribuições e sem se deixarem abater pelas maledicências que lhe são atribuídas, unir-se aos iguais em ações coletivas de preservação psicossocial. Não conseguem colocar as suas agressividades a serviço da proteção de suas vidas e sucumbem na apatia e conformismo na/pela violência social internalizada (Freud - El Malestar en La Cultura, 1981). A agressividade passível de ser colocada a serviço do fortalecimento egoico e para a preservação da vida individual e coletiva, sucumbe sobre a mais-repressão-social, que faz retornar para a subjetividade (ser reintrojetada) a corrosão de uma "culpa auto-punitiva" condizente ao enfraquecimento de toda a estrutura desejante, afetiva e cognitiva dos sujeitos - carregada de acusações e responsabilizações individualizantes com relação a todos os descaminhos culturais que, de fato, tem sua matriz na própria ordenação ético-política da sociedade contemporânea. Sob o sentimento de culpabilização (Freud, 1981) se esconde a origem social da violência contra o humano dos homens (Caniato \& Castro, 2002). Necessariamente, são os vínculos sadomasoquistas os que são estimulados e aceitos: dedique-se e acate tudo daquele que lhe ofende e é cruel com você! Não se processando a efetiva identificação do verdadeiro inimigo - agressor, a cidadania sucumbe sob estas perversões autoritárias. 
Este processo relacional nos faz lembrar o conceito de identificação com o agressor (Freud, 1978), estratégia de sobrevivência bastante frequente em pessoas sob tortura em que a ameaça à vida é sempre iminente.

A perversidade embutida na internalização destas atribuições sociais de malignidade (violência social internalizada) são difusas e antagônicas em especial quando se tornam inoperantes as funções egoicas de discriminação do real inimigo opressor. Revertida e deslocada para o mundo interno e inconsciente dos indivíduos, tais representações ideologicamente pervertidas, embebem a vida a vida psíquica dos sujeitos, passam a administrar seus desejos, seus sentimentos, seus pensamentos e suas ações nos moldes a torná-los cooperadores/cúmplices da crueldade social que os atormentam. O potencial destrutivo desta violência social internalizada, mantido sob repressão, pode assumir caminhos opostos. Um deles é a externalização em atos catárticos de vandalismo individual e/ou de pequenos grupos que, apenas, exprimem a vingança pelas violências vividas, mas trazem um alívio temporário e uma ilusão de vitória contra o opressor porque, também, apenas vem a confirmar e legitimar as atribuições de periculosidade anteriormente imputadas a tais indivíduos, para assim lançá-los nas malhas do aparato policial. O pior, ainda, ficam justificadas a aplicação de diferentes formas de coerção social, mais ou menos ostensiva contra estes indivíduos (Caniato et al., 2003). Outra expressão desta violência reprimida aparece nos indivíduos que são conduzidos a suportar, a aguentar e silenciar, as formas mais vis de sofrimento, sendo justificadas a indiferença à dor em nome de serem tais indivíduos detentores de capacidades humanas superiores (Adorno, 1986a) e/ou disfarçados como exigências necessárias na conquista da fama e do sucesso (Abeche et al., 2002). Mas tais violências corrosivas não terminam no âmbito da intimidade subjetiva neste prazer em "lamber as feridas" - e, sim, tais atrocidades penetram nos vínculos interpessoais nos moldes de que

aquele que é duro contra si mesmo adquire o direito de sê-la contra os demais e se vinga da dor que não teve a liberdade de demonstrar, que precisou reprimir. Esse mecanismo deve ser conscientizado, da mesma forma como deve ser fomentada uma educação que não mais premie a dor e a capacidade de suportá-la (Adorno, 1986a, p.39).

Não é exagero pensar com Adorno (1985) já que pode facilmente ser constado por uma observação, apenas, um pouco crítica, que na sociedade de consumo de massa as subjetividades vem sendo produzidas em série (padronização), inexistindo o propalado indivíduo-rei-soberano, presente apenas no discurso enganoso do individualismo ou, com diz Freud (1981), esvaziado dos elementos vitais de seu mundo interno, projetado na onipotência/impotência de um "deus como prótese" (p.3034). De fato, há uma impossibilidade, intencionalmente produzida, para que cada um não possa se tornar um ser-singular (pseudo - individuação). Sob a destrutividade perversa e impositiva são forjados os modelos indentificatórios que encarnam os valores sociais exigidos para a sustentação do status quo. Plenas de significados e sob glamour (sedução) tais representações ideologizadas são internalizadas e penetram na entranhas do mundo interno do sujeitos para esvaziar o que cada um possa ter de peculiar e singular. Para Adorno (1986c), sob manipulações violentadoras da indústria cultural, são destituídos o desejar, o sentir e o pensar próprios de cada um para apenas deixar em todos uma "máscara mortuária" (p.87). Na linguagem poética de Carlos Drummond de Andrade, as subjetividades são modeladas para portar, apenas, a nomeação das mercadorias, pelas quais a intimidade psíquica singular é substituída no "eu etiqueta".

Isto significa dizer que não são mais nos indivíduos singulares e nem nas trocas entre eles (coletivo), que a vida de cada um e de todos apóia-se como sendo seu locus, e nem mais a individualidade e as relações são administradas pelo mundo interno de sujeitos reais e singulares. Uma certa degenerescência domina o mundo interno dos sujeitos, não mais animados pela força vitalizadora de Eros, atravessando toda a estrutura psíquica dos indivíduos. Assim fragilizados, não mais, apenas, se vergam aos investimentos libidinosos idealizados em um outro humano, embora seja este outro um tirano, como pensava Freud em Psicología de las masas em 1921 (1948).

Muito mais rastejantes estamos todos a procura de um objeto para nele depositarmos nossos investimentos "amorosos" libidinais na realização dos nossos desejos: a ditadura é a da mercadoria que dá suporte, apenas, a uma promessa de satisfação que nunca se realiza. Seria oportuno que, apoiados na insatisfação e procura compulsiva de novos objetos para o gozo, que o ser humano pudesse despertar para a perversidade narcísica dos vínculos diretos com ou nos substitutivos do outro humano que os 
indivíduos estão deslocando para a mercadoria. Não faltam alertas, como o de Bauman (1999):

Para aumentar sua capacidade de consumo, os consumidores não devem nunca ter descanso. Precisam ser mantidos acordados e em alerta sempre, continuamente expostos a novas tentações, num estado de excitação incessante e também, com efeito, em estado de perpétua suspeita e pronta insatisfação. As iscas que os levam a desviar a atenção precisam confirmar a suspeita, prometendo uma saída para a insatisfação: 'Você não acha que já viu tudo? Você ainda não viu nada!' (p.92-93)

Se inexiste o espaço público para trocas, convivência e acolhimento, se a cidadania possível é apenas a da sujeição das subjetividades às atribuições de malignidade e/ou à vigilância e o confinamento mais ou menos velados (Abeche e outros, 2002) o que pensar da vida privada sob estas diferentes forças invasivo-violentadoras na qual nem mais o prazer da sexualidade genital está sendo possível sem os holofotes — presença de outros atores sociais que não mais o par e/ou de personagens dos filmes pornográficos sob o pretexto de "produção de fantasias excitantes"? (Freud, 1981, p.3044). Pelo menos suspeição, ameaça, medo, impotência tomam conta da vida íntima dos sujeitos... Até o pensar exige certo grau de solidão e recolhimento como nos diz Piera Aulagnier (apud Costa, 1999):

O direito ao segredo era a condição para poder pensar. Nosso sentido de identidade, continuava ela, deriva, em grande parte, da capacidade que temos de dizer o que, quando e como a certas pessoas em certas ocasiões. Quando o pensamento corre à nossa revelia, quando seu curso perde o prumo é a individualidade que se desfaz (p.17).

Certamente não é a singularidade que está em construção mas, sim, a perda da identidade individual na simbiose osmótica sob a indiferença de um e no/pelo outro, de uma não delimitação regressiva do eu e do não-eu, da dissolução dos sujeitos pelo horror e por sentimento de rejeição numa homogeneização estéril, da não-pertinência e na indiferenciação da vivência de um etéreo esvoaçante encarnado na mercadoria, de singularidades expostas somente a violência social e internalizada transformada em acusações sabotadoras no sentimento de culpabilização. Onde estará a saída desta obscuridade irracional cruel em que a vida humana esta submersa na chamada civilização ou barbárie atuais?
Algumas implicações alienantes/alienadoras da negligência ético política nas práticas "psi"

Quando negligenciamos com estas determinações heterônomas (sociais) da dor, do sofrimento e do adoecer subjetivos, por ingenuidade e/ou porque tornados cegos e surdos pelo dogma do apoliticismo da ciência, caímos na armadilha da imanência do psíquico e nela sucumbimos na cumplicidade com estes massacres que o processo civilizatório vem produzindo contra as exigências do humano dos sujeitos. O refúgio teórico-prático na imanência, centrado na crença que no mundo interno dos sujeitos está a origem e o fim de todos os processos psíquicos-as subjetividades passam a ser mônadas fechadas em torno de si mesma e incomunicaváveis entre si apenas legitima a destruição da vida individual-coletiva, justifica a impossibilidade de troca entre diferentes e sustenta o deslocamento narcísico para um estilo de vida imposto socialmente (Lowen, 1993) no qual o enamoramento tornou-se impossível entre alteridades distintas. A este processo de destruição do coletivo, do confinamento da vida psíquica à pura interioridade (individualismo exacerbado) e a transposição e apego dos vínculos humanos para os investimentos libidinosos de forma sôfrega às coisas é o que Sennett (1993) denomina de tiranias da intimidade.

É equivocado pensar que seja possível construir a felicidade dos indivíduos se mantivermos esta perspectiva intimista que sustenta a proibição de trocas afetivas entre os sujeitos e de compartilhar desejos e pensamentos que sob a tirania da intimidade seguem a lógica do individualismo da segregação, da solidão, da competição, do pânico substituindo trocas amorosas e solidárias entre os homens. Como diz Bader (1999):

(...) a felicidade pública é diferente do prazer e da alegria. Estes últimos são emoções imediatas contingentes do que Heller define como dor, circunscritas ao instante de sua ocorrência, e aparecem como flashes na vivência do sofrimento ético-político, sem alterar-lhe a qualidade (...)

Todos sentem alegria e prazer com a conquista das reinvidicações, mas nem todos sentem a felicidade pública. Esta é experienciada apenas pelos que sentem a vitória como conquista da cidadania [da vivência solidária, amorosa, terna entre os homens] e da emancipação de si e do outro, e não apenas de bens materiais circunscritos. A felicidade ético-política é sentida quando se ultrapassa a prática do individualismo e do corporativismo para abrir se à humanidade (p.105, grifos nossos). 
É equivocado pensar construir a felicidade de para e entre os homens se não mudarmos nossas concepções e práticas do que é ser-indivíduosingular e da construção de uma nova ordem para as relações sociais se não abandonarmos as ações cruéis das quais compartilhamos quando damos, mesmo que inconscientes e silenciosos, adesão ao intimismo individualista. A sabedoria dos velhos Marx e Freud, as quais vale a pena nos curvar, funda-se na concepção do homem como o ser da dependência e da necessidade de amparo para aí, sim, podermos ousar pensar e agir para se tornar viável uma nova forma de ser-indivíduo-singular que viva sob o teto de novas leis organizadoras da vida coletiva, isto é, recupere sua dimensão sujeito e o sentido da alteridade para que atinja o ser-cidadão, de fato. Aqui podemos falar que

a referência ao sofrimento e a felicidade ético-política é a negacão desta afetividade narcísica do final do milênio. Ela remete à utopia socialista do início do séc. XIX, onde significava a procura de uma outra gestão da tensão entre razão e paixão, entre indivíduo e comunidade, entre desejo e dever.

Fiador do laço ameaçado pela razão calculadora, o direito à felicidade, cuja realização orienta os desejos e as paixões múltiplas, torna-se a medida com a qual se julga uma política que sacrifica o justo ao eficaz, e que vê na multiplicidade humana apenas um perigo mortal, e não um potencial inexplorado de possibilidades sociais não realizadas (Sawaia, 1999, p.106 com citação de Vanikas, 1997, p.63).

Não há dúvida que a saída da fragmentação do conhecimento, tal como referida no início destas reflexões, constitui-se numa utopia fundada na esperança do rompimento da dimensão intimista e compartimentalizada do saber-fazer psicológicos. Porém nesta mudança não cabe nem a onipotência, tão familiar aos psicólogos, nem a impotência de seus clientesvítimas e nem sequer a manutenção de um certo servilismo quando buscamos a intencionalidade valorativa e o resgate ético de uma totalidade perdida do que seja o ser-homem presentes nestas teorizações e práticas da Psicologia. Precisamos no dar conta da determinação biológica do homem sem nos vergarmos, de forma reducionista, aos importantes avanços da genética; necessitamos de certa dose de rebelião para nos apropriarmos do desejar, sentir, pensar e agir do psiquismo humano, para que possamos colaborar para reorientá-lo para o "mundo da vida" e cooperar na recuperação de sua práxis enquanto sujeito histórico, condizente a aceitação de sua missão de construtor de laços com o outro-diferente-de-si, para o rompimento das simbioses narcísicas da atualidade e da ordem social violenta, excludente e injusta na qual vivemos. Precisamos ser ousados por que sabemos poder sofrer represálias quando nos aliamos com nossa práxis no resgate de uma subjetividade verdadeiramente cidadã (Caniato et al., 2003).

\section{Referências}

Abeche, Regina P.C e outros (2002). É hora do espetáculo da perversidade: o aprisionamento da subjetividade dentro dos reality shows. Trabalho apresentado no III Encontro Latinoamericano dos Estados Gerais da Psicanálise. Buenos Aires, 14-17 novo

Adorno, Theodor W. (1986a). Educação após Auschwvitz. Em G. Cohn (Org.), Sociologia - Theodor Adorno (pp.33-45). São Paulo: Ática. (Grandes Cientista, 54).

Adorno, Theodor W. (1986b). Sobre música popular. Em G. Cohn (Org.), Sociologia - Theodor Adorno (pp.115-146). São Paulo: Ática (Grandes Cientistas, 54).

Adorno, Theodor W. (1986c). Crítica cultural. Em G. Cohn (Org.), Sociologia - Theodor Adorno (pp.77-90). São Paulo: Ática (Grandes Cientistas, 54).

Adorno, Theodor W., \& Horkheimer, Max (1985). Dialética do esclarecimento: fragmentos filosóficos. (G. A. de Almeida, Trad.) Rio de Janeiro: Jorge Zahar.

Arendt, Hannah (2000). Eichmann em Jerusalém: um relato sobre a banalidade do mal. (J. R. Siqueira, Trad.) São Paulo: Companhia das Letras.

Arendt, Hannah (1978). O sistema totalitário. (R. Raposo, Trad.) Lisboa: Dom Quixote (Coleção Universidade Moderna, 60).

Baudrillard, Jean. A violência da Globalização. Disponível em: http://diplo.uol.com.br/2002-11a469. (Acessado em 15/02/2003)

Bauman, Zygmunt (1998). Modernidade e holocausto. (M. Penchel, Trad.) Rio de Janeiro: Jorge Zahar. 
Bauman, Zygmunt (1999). Globalização: as consequências humanas. (M. Penchel, Trad.) Rio de Janeiro: Jorge Zahar.

Benjamin, Walter. Crítica da violência: crítica do poder. Disponível em: http://www.espacoacademico.com.br/21tc_benjamin.htm. (Acessado em $07 / 02 / 2002$ )

Berto, Frei (2002). O significado da vitória de Lula para a esquerda. A estrela sobe. Caros Amigos. 69, 18-19.

Caniato, Angela \& Castro, Michele (2002) Matrizes psicossociais do sofrimento humano na contemporaneidade. Trabalho apresentado no III Encontro Latinoamericano dos Estados Gerais da Psicanálise. Buenos Aires, 14-17 novo.

Caniato, Angela (1999). A impunidade na sociedade e no direito: implicações psicossociais. Psicologia - UFF. 11 (2-3), 9-26, maidez.

Caniato, Angela e outros (2003). Phenix: a ousadia do renascimento da subjetividade cidadã II. Psicologia e Sociedade. 14 (2), (no prelo).

Caniato, Angela Maria Pires (1995). A história negada: violência e cidadania sob um enfoque psicopolítica. Tese de Doutorado, Instituto de Psicologia da USP.

Caniato, Angela Maria Pires (1999). A subjetividade na contemporaneidade: da estandardização dos indivíduos ao personalismo narcísico. Em A. F. Andréa e outros (Orgs.), Cidadania e participação social (pp.13-29). Porto Alegre: ABRAPSOSUL.

Caniato, Angela Maria Pires (2000). Da violência no ethos cultural autoritário da contemporaneidade e do sofrimento psicossocial. PSI — Revista de Psicologia Social e Institucional. 2 (2), 197-215.

Carone, Iray (1991). De Frankfurt à Budapeste: os paradoxos de uma psicologia de base marxista. Psicologia - USP. 2(1-2), 111-120.

Chomsky, Noam (2002). 11 de setembro. (L. A. Aguiar, Trad.) Rio de Janeiro: Bertrand Brasil.

Cohn, G. (1986a). Sociologia - Theodor Adorno. São Paulo: Ática. (Grandes Cientistas, 54).
Coimbra, Cecília (2001). Operação Rio: o mito das classes perigosas. Um estudo sobre a violência urbana, a mídia impressa e os discursos de segurança pública. Rio de Janeiro/Niterói: Oficina do Autor/Intertexto.

Costa, Jurandir Freire (1999). Razões públicas, emoções privadas. Rio de Janeiro: Rocco.

Dejours, Christophe (1999). A violência invisível - entrevista. Caros Amigos. 26, 16-17.

Dejours, Christophe (2000). A banalização da injustiça social. (A Monjardim, Trad.) Rio de Janeiro: FGV.

Derrida, Jacques. A razão do mais forte. Disponível em: http://www.diplo.com.br/fechado/materia.php?id=527 (Acessado em $15 / 02 / 2003)$

Figueiredo, Luis Claudio M (1995). Revisitando as psicologias: da epistemologia à ética das práticas e discursos psicológicos. São Paulo/Petrópolis: Educ/Vozes.

Freud, Anna (1978). O ego e os mecanismos de defesa. (A. Cabral, Trad.) Rio de Janeiro: Civilização Brasileira.

Freud, Sigmund (1948). Psicología de las masas. Em S. Freud, Obras Completas (pp.1119-1157). Madrid: Biblioteca Nueva (vol. 1).

Freud, Sigmund (1981). El malestar en la cultura. Em S. Freud, Obras Completas (pp.3018-3067). Madrid: Biblioteca Nueva (Tomo III).

Guinsberg, Enrique (2001). La salud mental en el neoliberalismo. México: Plaza y Valdés.

Jensen, Henning (1986), Teoría Crítica del Sujeto: ensayos sobre psicoanálisis y materialismo histórico. México: Siglo Veintiuno.

Kaës, René (1991). Rupturas catastróficas y trabajo de la memoria. Notas para una investigación. Em J. Puget \& R. Kaës (Orgs.) Violencia de Estado y Psicoanálisis (pp.137-163). Buenos Aires: Centro Editor de America Latina. 
Kehl, Maria Rita. Visibilidade e espetáculo. Disponível em: www.estadosgerais.org/terceiro encontro/kehl-espetáculo.shtml. (Acessado em 16/02/2003).

Lowen, Alexander (1993). Narcisismo. Negação do verdadeiro Self. (A. Cabral, Trad.) São Paulo: Cultrix.

Mariotti, Humberto (2000). A era da avareza: a concentração de renda como patologia bio-psico-social. Trabalho apresentado na Associação Pala Athena. Ciclo de Estudos: as dores da alma. São Paulo, 20 out.

Martin, Hans Peter \& Schumann, Harald (1999). A armadilha da globalização: o assalto à democracia e ao bem-estar social. (U.E. Waldtraut, R. Sackiewez \& C. Sackiewez, Trad.) São Paulo: Globo.

Martín-Baró, Ignácio (1987). El latino indolente: carater ideológico del fatalismo latinoamericano. Em M. Maritza (Coord.) Psicologia política latinoamericana (135-162). Caracas: Panapo.

Martín-Baró, Ignácio (1989). In memoriam. Revista de Psicologia de El Salvador. 9 (35), 1-172.

Mendolowics, Eliane (2001). Psicanálise e contemporaneidade: a dor da solidão. Disponível em: psychanalyse.net/archives/texte117.html. (Acessado em 21/09/2002).

Sawaia, Bader B. (1995). Psicologia social: aspectos epistemológicos e éticos. Em S.T.M .. Lane \& B.B. Sawaia (Orgs.), Novas veredas da Psicologia Social (pp.45-53). São Paulo:Educ/Brasiliense.

Sawaia, Bader B. (1999). O sofrimento ético-político como categoria de análise da dialética exclusão/inclusão. Em B.B. Sawaia (Org), As artimanhas da exclusão: análise psicossocial e ética da desigualdade social (pp.97-118). Petrópolis: Vozes.

Sennett, Richard (1993). O declínio do homem público: as tiranias da intimidade. (L. A. Watanabe, Trad.) São Paulo: Companhia das Letras.
Sennett, Richard (2001). A corrosão do caráter: consequências pessoais do trabalho no novo capitalismo. (M. Santarrita, Trad.) Rio de Janeiro: Record.

Ulloa, Fernado O. (2001a). Sociedad y crueldad (notas preliminares). http://www.etatsgenerauxpsvchanalvse.net/archives/texte171.html. (Acessado em: 21/09/2002)

Ulloa, Fernado O. (2001b). Uma perspectiva psicanalítica de la crueldad. http://www.etatsgenerauxpsvchanalvse.net/archives/texte90.html. (Acessado em 21/09/2002)

Vianna, Helena Besserman (1994). Não conte a ninguém... Contribuição à história das Sociedades Psicanalistas do Rio de Janeiro. Rio de Janeiro: Imago. 


\section{A psicologia na construção da igualdade}

Marlene Neves Strey ${ }^{1}$

Trabalhar com Psicologia Social é um desafio que encanta e, ao mesmo tempo, eleva o nível de ansiedade do/a profissional, na medida em que complica em muito o entendimento do ser humano. Em vez de buscarmos respostas no intrapsíquico, aumentamos nosso âmbito de olhar e de escuta, para incluir estudar o indivíduo no conjunto de suas relações sociais, como há muitos anos atrás nos ensinou Silvia Lane (1980, p.97).

Obviamente que, ao tornarmos mais complexo o nosso campo de estudos, entendimentos e prática, afinamos nosso entendimento da "realidade", mas, também, aumentamos a quantidade de preocupações e de buscas, o que aumenta a nossa responsabilidade e, portanto, a nossa ansiedade.

Centrando o foco deste texto na Universidade em geral e nas Faculdades de Psicologia em particular, verificamos, nas nossas andanças por aí que, atualmente, existe plena consciência da necessidade de olharmos o mundo cambiante em que vivemos com olhos diferentes de outras épocas, em que tudo parecia mais estável e permanente.

Aparentemente, existe uma busca, por parte de todos/as os/as envolvidos (professores/as, alunos/as, etc.) e transformação social, tendo como base e orientação a ciência, da qual a universidade é o templo.

E aqui, temos duas notícias, uma boa e uma má. A boa é que, ao nos aplicarmos à pesquisa, à busca da verdade científica, estamos realmente ampliando o campo do conhecimento e desvelando os segredos da vida e da natureza. A notícia má, é que poderemos enveredar cegamente por tais conhecimentos, não em atitude de crítica científica, mas de crença e idolatria, esquecendo que a ciência nada mais é do que uma das tantas criações humanas, sujeitas a todos os tipos de enganos e, até mesmo, mistificações, bem ou mal intencionadas. Suas verdades, mesmo as mais consagradas, nada mais são do que possíveis verdades entre tantas outras possíveis verdades.

${ }^{1}$ Doutora em Psicologia Social. Docente e Pesquisadora na Faculdade de Psicologia da PUCRS.
Então, o olhar crítico é tão essencial quanto à dedicação à busca do saber e o desenvolvimento de nossas teorias científicas.

Isso é fundamental, pois não basta ser rotulado de científico para ser ético, na medida em que podemos ter ideias muito diferentes sobre o que seja transformação social ou o que qualificamos como exercício transformador. Também devemos ter uma ideia de como se relaciona a teoria com o processo de transformação, se a própria teoria é uma tarefa transformadora ou se a transformação é um dos seus efeitos (Buttler, 2001, p.7).

Mesmo que a teoria em si mesma seja transformadora, ela não é suficiente para a transformação social e política. Além da teoria, deve haver algo mais, intervenções em nível social e político que implicam ações, trabalho sustentado, prática institucionalizada, o que não é exatamente o mesmo que o exercício da teoria, ainda que todas estas práticas sejam pressupostas na teoria. Segundo Buttler (2001), na transformação social, todos/as nós somos filósofos/as não especialistas, que temos uma visão de mundo, do que está e do que não está bem, do que é justo e do que é detestável, daquilo que a ação humana é ou pode ser, do que constituem as condições de vida necessárias e suficientes para a construção da autonomia e expansão de nosso universo, de possibilidades de ampliação de nossas identidades.

É bom que não nos esqueçamos que não só somos homens ou mulheres, brancos ou negros, heterossexuais ou homossexuais, somos muito mais, somos únicos, como é único cada indivíduo de qualquer uma das espécies vivas do planeta. "Não há, pois, uma única e universal natureza inata" (Barral Morán, 2001, p.157), que necessite das mesmas satisfações às suas necessidades que, por sinal, podem variar enormemente.

Isso bate frontalmente com as teorias que explicam o comportamento humano a partir de bases genéticas, biológicas, psicológicas, sociais ou mesmo históricas, rígidas e imutáveis, que determinam nosso modo de ser. Certas tendências e condutas aparentemente invariadas, partem do fato de que, conforme explica a médica anatomista María José Barral Morán (2001, p.155), utilizando um argumento da ordem do biológico, a leva a dizer que

... a capacidade dos neurônios (chamada "plasticidade neuronal" e que dura toda a vida) de estabelecer novos contatos diante de estímulos externos, da qual deriva a capacidade de nosso cérebro de 
adquirir novas funções e modificar condutas, nos permite, nas palavras de Ruth Bleier, "adaptar-nos" ao nosso ambiente e chegar a aceitar como "natural" nosso próprio lugar nesse ambiente.

Ambiente que está dicotomizado, dependendo de se o corpo é de homem ou de mulher, de branco ou de negro, de heterossexual ou homossexual e a estas dicotomizações a "ciência" contribui demonstrando suas bases biológico-naturais. Assim, as teorias científicas, psicológicas ou pedagógicas, ao mesmo tempo em que podem nos ajudar a conhecer mais determinados fatos ou condições humanas, também podem, muitas vezes ao mesmo tempo, ajudar a obscurecer parte ou mesmo toda uma realidade.

Por outro lado, o fato de encararmos cada ser humano como único, sem igual, pode nos levar a aceitar teses individualistas, através das quais veremos os indivíduos como os únicos que podem e devem encontrar seu caminho na vida, sendo, portanto, os responsáveis, também únicos, por suas escolhas, caminhos e resultados obtidos. Essas teses individualistas, tão caras ao nosso mundo ocidental, fazem-nos esquecer ou camuflam o fato de que nossas sociedades estão organizadas de tal maneira que nós, os indivíduos, estamos presos/as em tramas de poder que vão muito além de nossa vontade individual ou de nossa consciência.

Assim, mais do que nunca é necessário que tenhamos uma concepção de aluno e de aluna que escape do individualismo e aposte numa concepção humanista, ou seja, que queiramos que cada um/a seja autônomo/a, tenha capacidades reflexivas e críticas, responsabilizando-se por um projeto de vida individualizado, mas que só se sabe viável no âmbito de um reconhecimento solidário; com um adestramento para a interação em estruturas de reciprocidade como constitutivo de toda possível vida moral; a participação no espaço público, esfera do poder explícito e legítimo, como o leito possível e eficaz para a promoção da própria potência e da incidência ativa na configuração das condições da vida coletiva, que a todos afetam (Amorós, 2000).

Se prezamos a Democracia, tampouco podemos esquecer que os valores de uma sociedade democrática não seriam sequer concebíveis se não estiverem intimamente relacionados com os de uma concepção humanista de sujeito: sem sujeitos autônomos, responsáveis, reflexivos e críticos, o projeto democrático careceria de sentido (Idem).
Em artigo publicado no Jornal La Razón de Madri, em 14 de fevereiro de 2002, Antonio García Trevijano fala que, em momentos como os atuais, em que está havendo um emagrecimento cultural, com consequentes e diferentes tentativas de elevação do nível educativo dos/as jovens, devemos estar muito atentos/as para que não aconteçam novas e distintas discriminações. Segundo García Trevijano, a política deve corrigir as injustiças derivadas das desigualdades individuais surgidas dentro de uma mesma e única espécie humana. Uma sociedade que almeja uma civilização avançada, tem o dever, segundo ele, de suprimir as desigualdades ou, pelo menos, de diluir seus perfis sociais para que não sejam motivo de discriminação, pois, de outro modo, cairíamos em um darwinismo social cada vez mais inquietante. Os caminhos para a transformação podem ser diferentes, pois, a igualdade não deveria imperar no caminho, mas sim na meta.

Ao olharmos o mundo de uma maneira geral e às pessoas particularmente, necessariamente nos daremos conta que a diversidade é a norma. Além disso, mais cedo ou mais tarde acabamos nos conscientizando que temos inúmeras limitações, que, a cada dia, para sobreviver, necessitamos aprender coisas novas, novos comportamentos, novas habilidades. Também nos damos conta de que não somos autossuficientes, de que nunca conseguiremos fazer determinadas coisas e, por isso, necessitamos dos demais. Todas essas descobertas são bastante inquietantes e, talvez por isso, busquemos no conhecido, no familiar, maneiras de aquietarmos a ansiedade produzida pelo simples fato de sermos dotados de consciência. Ao sossegarmos e acobertarmos a ansiedade diante do novo, estamos, também, impossibilitando viver o mundo em toda sua riqueza e diversidade.

Assim, a tarefa educativa apresenta uma responsabilidade ética das mais importantes. Até que ponto devemos ou podemos ampliar horizontes? Que valores devemos enfatizar? Que normas devemos impor? Ou não devemos estabelecer normas? Aqui, gostaria de lembrar que, se alguém se opõe à normatização, é em nome de uma norma diferente (Buttler, 2001).

Se ensinamos a nossa norma como a única verdadeira e louvável, estamos restringindo a possibilidade de autonomia de nossos/as educandos/as. Mas, se os/as deixamos à deriva, estaremos entregando a quem diminua sua ansiedade a responsabilidade de, quem sabe, formar seus valores e normas de uma maneira ainda mais estreita que a nossa. 
Os desafios da prática educativa são muitos. Seria difícil enumerá-los, pois a cada dia que passa encontramos um novo, do qual não nos havíamos dado conta antes. Mas eu diria que a famosa dicotomia autoritarismo/lassaizfaire é uma das mais comuns. Saber exatamente como nos comportamos no processo ensino-aprendizagem exige muito esforço e reflexão, tendo em mente que provavelmente nos aproximaremos de um polo ou de outro dependendo da ocasião, das pressões que se abatem sobre nós e da consciência de que os outros são seres difíceis de serem conhecidos.

Alguns conceitos deveriam ser parte indissociada de nossa reflexão diária se queremos um mundo mais igualitário e justo. Quando falamos em igualdade, imediatamente associamos outro conceito, o de equidade. Segundo Barr (apud Vargas, Vázquez e Jané, 2002, p.928)

o conceito de equidade se relaciona com aquilo que consideramos, "justo" e, portanto, seu significado depende dos valores ou enfoques de sociedade e justiça social, que adotem indivíduos, grupos ou governos.

Continuando com essas autoras,

O enfoque igualitarista se apoia no conceito de justiça social da filosofia comunitária, que considera a solidariedade e a unidade social como algo bom em si mesmo (...) É dado preferência à distribuição dos recursos para alcançar a igualdade de bem-estar ou a igualdade de recursos acima dos objetivos de maximização do bemestar econômico dos indivíduos, com base exclusivamente em critérios de eficiência, que podem conduzir à desigualdade entre grupos e populações (Idem, p.928).

Assim, por exemplo, as políticas públicas deveriam ter por meta a eliminação das desigualdades por meio de todos os seus programas em todas as áreas, quer seja na saúde, na educação ou na economia. As autoras acima mencionadas ainda lembram que

pode-se dizer que a contribuição do pensamento contemporâneo se centra na valorização da noção de igualdade como objetivo final, seja de bens primários, de oportunidades e condições (capacidades) seja de realizações fundamentais, assim como o reconhecimento explícito de fatores determinantes das diferenças existentes, que estão relacionadas com aspectos biológicos, sociais e político organizacionais. Em outras palavras, assume a necessidade de assegurar direitos igualitários à parte das diferenças individuais (Idem, p.942).

Neste ponto, é importante trazer à nossa discussão um outro conceito que, junto com as ciências, as teorias, as políticas públicas, deve ter grande centralidade em nossas práticas pedagógicas na Psicologia: o conceito de Cidadania.

Falar em cidadania requer, em primeiro lugar, que explicitemos o que significa essas palavra para quem fala. Para nós, cidadania é algo que, em princípio, seria um direito, um dever, uma postura de cada pessoa que nasce em um determinado país. É a identidade de cidadão ou cidadã. E, para ser identidade, necessita de reconhecimento e esse reconhecimento tem que ser de caráter nivelador e igualitário (Rojas, 1995). Só que, ao dizer isso, ficam escondidos um mundo de significados que podem tornar essa palavra, cidadania, cheia de vida ou simplesmente, apenas isso, uma palavra.

Ser um cidadão ou uma cidadã equivaleria a ser por inteiro como pessoa, podendo usufruir de todas as possibilidades em todos os aspectos de sua vida enquanto tal, num efetivo exercício das possibilidades humanas. Só que isso não acontece espontaneamente, pelo simples fato da pessoa ter nascido. Em nosso País, para falarmos apenas no Brasil, temos incontáveis exemplos de gente que existe, mas que pouco tem de semelhante a uma pessoa inteira.

Sabemos que nossa Constituição garante condições de igualdade a todos os cidadãos e a todas as cidadãs, não importando o sexo, a raça, o credo. No entanto, a vida real é muito diferente das palavras escritas em um papel. A remoção da desigualdade no trabalho, na educação, na vida conjugal e em todas as instâncias macrossociais e microrrelacionais é um exercício muito mais sutil e difuso do que a incorporação de políticas igualitárias.

$\mathrm{Na}$ área da Educação, em todos os níveis, existem muitos/as professores/as bastante interessados/as em fazer da desigualdade uma coisa do passado, no entanto, o ambiente educacional tem um efeito sobre os/as alunos/as que ultrapassa em muito a figura do indivíduo professor. $\mathrm{Na}$ realidade, o impacto do/a professor/a individualmente é limitado e, eventualmente, sofre a influência do colegiado que congrega gente de múltiplas tendências teóricas, muitas das quais não contemplam a questão da igualdade. Se o caso é esse, o colegiado acaba por reforçar estereótipos 
que podem explicar a razão pela qual as desigualdades continuam a existir, sem que as pessoas se dêem conta da situação e da sua contribuição para a manutenção do status quo (Demaine, 1989).

A proposição de Bernstein (1986) pode nos ajudar a entender essa situação. De acordo com esse autor, o discurso pedagógico não possui um discurso próprio, mas opera por meio de um sistema de normas para dotar o discurso da competência em um discurso da ordem social, de maneira que o último domine o primeiro. Desta maneira, a função do ambiente educacional como o lugar para a reprodução da natureza hierárquica da sociedade patriarcal (onde os homens têm ascendência sobre as mulheres, os mais velhos sobre os mais jovens, etc.) é reconhecido como mais valioso do que a aquisição e a construção de disciplinas acadêmicas. Assim, uma distribuição hierárquica do conhecimento é assumida nesta conceitualização das normas que governam o sistema educacional, entre as quais o estado é caracterizado pelas dicotomias e divisões de classe, de raça, de gênero.

Embora a história da humanidade sempre tenha evidenciado diversos tipos de ruptura com ideias e práticas de dominação de umas pessoas sobre outras, ainda assim continuam a existir ideias estereotipadas que estão na base de relações desiguais, nas quais é provável que estejam acontecendo atos e experiências discriminatórias, muitas das quais são extremamente violentas. Como nos lembra o Relatório Cladem (2000), apesar da escravidão ter sido abolida lá no século XIX, ainda existem práticas racistas que condenam grupos inteiros a uma vida sem direitos pelo simples fato de terem uma pele desta ou daquela cor.

\section{Nesse sentido,}

não basta nomear e descrever violências, não basta revelar suas vítimas e agentes, não basta descobrir onde acontecem. É preciso reparar nos fenômenos que se cruzam e nos sentidos que se ocultam (Idem, p.24).

Como é explicitado no Relatório do Cladem (2000, p.25)

em horizontes culturais nos quais a força é fonte de prestígio, danificar torna-se um assunto de graduação e custos relativos, nos quais sempre se conservam possibilidades aceitáveis. Com medições, explicações e outros encobrimentos são anestesiadas nossas sensibilidades. O saber dos especialistas disciplina os corpos para que não reconheçam suas feridas. Vão nos acomodando com justificativas, para que o mal-estar não se transforme em expressão política. Não há motivo para se comover, nem todo dano é desmedido.

Assim, necessitamos ter em mente, exaustivamente, professores/as, alunos/as, profissionais, que estas questões têm que fazer parte de nossas preocupações teóricas e de nossa prática. Temos que exercer influência política no sentido de pressionar toda a sociedade e as instâncias governamentais, pois como aponta Cladem

Cabe notar que, em matéria de direitos humanos, é preciso que o Estado exerça a autoridade e a função pública, sujeitando-se a três deveres: dever de respeitá-los, dever de protegê-los e dever de obter sua realização. Desse ponto de vista, é relevante que, ao lado do reconhecimento de direitos e liberdades fundamentais, sejam configuradas e asseguradas condições e capacidades para seu exercício e gozo. Os direitos humanos não são um catálogo de aspirações. A experiência mundial tem demonstrado que os avanços substanciais, aqueles que transcendem o plano formal, acontecem em contexto democráticos onde os cidadãos e as cidadãs dispõem de capacidades pessoais e coletivas para vigiar e orientar o desempenho estatal no que se refere à observância dos padrões internacionais de direitos humanos. A experiência mundial também evidenciou que, em contextos autoritários ou com fraco desenvolvimento democrático, os direitos humanos costumam ficar reduzidos a meros enunciados. Em nossa região [América Latina], o chamado problema da distância entre lei e realidade reflete de forma importante um problema estrutural sobre a qualidade de nossas democracias." (Cladem, 2000, p.3940)

Agora que já discutimos um pouco e muito brevemente, é verdade, o papel do contexto na prática pedagógica, vamos tentar adentrar, também de maneira breve, sobre o que anda acontecendo em nossos cursos de psicologia. Que critérios e objetivos embasam nossos currículos? Que tipo de preocupações temos no tocante à visão de mundo que as teorias que usamos apresentam aos estudantes? Essas são questões fundamentais, tendo em vista que cada teoria tem embutido em si uma prática e uma ética, mesmo que não sejam explicitadas. 
A experiência nos tem ensinado que, nem sempre, o discurso e a prática andam de mãos dadas numa mesma direção. Em encontros, congressos e seminários temos escutado exaustivamente preocupações de ordem social dentro da psicologia. No entanto, na sala de aula, nos estágios e nas práticas disciplinares, essa preocupação muitas vezes é diminuída sob o peso das preocupações teórico-técnicas e metodológicas. Não que isso não seja importante, ou mesmo de extrema importância, mas sem reflexão crítica sobre o que a teoria e/ou a prática significam em outras instâncias que a teórico/metodológica, essa importância fica parcial ou mesmo vazia.

Por isso nunca é demais enfatizar a necessidade de quotidianamente revermos, junto com nossos/as alunos/as o que significa realmente aquilo que estamos ensinando/aprendendo, pois, como salienta Guareschi (1994, p.13)

é preciso ter cuidado com as teorias e ver o "vazio" que elas deixam para trás. Esse vazio, às vezes, não pode ser mesmo preenchido. Algumas vezes ele pode ser preenchido, mas é deixado incompleto de propósito. Isto é, há interesses em se deixar uma coisa mal explicada, pois do contrário ela poderá nos prejudicar.

A ideia aqui não era dar respostas, mas sim suscitar o debate. Passando por todas essas reflexões, esperamos ter contribuído para também refletirmos sobre que tipo de intervenções temos estimulado em nossas universidades, quais as contribuições temos feito para o desenvolvimento da Psicologia Social e da Psicologia como um todo e para a discussão ética de nossa práxis.

\section{Referências}

Amorós, C. (2000) Tiempo de feminismo. Sobre feminismo, proyedo ilustrado y postmodernidad. Madrid: Cátedra.

Barral Morán, M. J. (2001) "Genes, género y cultura.” In C. Miqueo, C. Tomás, C.

Tejero, M.J. Barral, T. Fernández e T. Vago (Eds.) Perspectivas de género en salud. Madrid: Minerva Ediciones.

Bernstein, B. (1986) On pedagogic discourse. In Richardson, J. (Ed.) Handbook of theory and research for the sociology of education. Nova Iorque: Greenwood.
Butter, J. (2001) La cuestión de la transformación social. In E. BeckGernsheim, J. Butter e L. Puiguert (Eds.) Mujeres y transformaciones sociales. Barcelona: EI Roure Editorial.

Cladem (2000) Questão de vida. Balanço regional e desafios sobre o direito das mulheres a uma vida livre de violência. Lima (Peru): Comitê Latino-Americano e do Caribe para a Defesa dos Direitos da Mulher.

Demaine, J. (1989) Race, categorisation and educational achievement. British Journal of Sociology of Education. Vol. 10, n 2, p.195-214.

Guareschi, P. A . (1994) Sociologia crítica. Alternativas de mudança. Porto Alegre: Mundo Jovem.

Lane, S. T. M. (1980) "Uma redefinição da psicologia social." Educação e Sociedade. Vol. 2, N. 6, p.96-103.

Rojas, Marcela (1995) Adolescência e AIDS: avatares humanos de uma educação silenciosa. Educação. Subjetividade e Poder. Vol. 2, no 2, p.9-14.

Vargas, I.; Vázquez, M. L. e Jané, Elisabet (2002) Equidad y reformas de los sistemas de salud en Latinoamérica. Cadernos de Saúde Pública. 18 (4), p.927-937. 


\section{Práxis e ética na psicologia social comunitária: possibilidades de transformação social na vida cotidiana ${ }^{1}$}

Maria de Fatima Quintal de Freitas ${ }^{2}$

Adentrar no terreno da discussão sobre Ética e Paradigmas na relação com a Prática dos profissionais de psicologia, exige, em nossa perspectiva, que consideremos três dimensões intrinsecamente relacionadas. A dimensão ontológica, através da qual torna-se possível identificar os conteúdos das concepções sobre Sociedade e sobre Homem, presentes nos diferentes tipos de práticas realizadas. A dimensão epistemológica que nos remete a uma análise sobre a natureza da relação de conhecimento produzida e, consequentemente, sobre o tipo de implicação entre profissional e comunidade. E, a dimensão da práxis, como uma resultante do entrecruzamento das duas anteriores, em que torna-se possível analisar os impactos sociais e psicossociais do trabalho desenvolvido.

Assim, para a proposta aqui formulada, pretende-se tecer algumas considerações sobre a Psicologia Social Comunitária, na perspectiva de uma práxis comprometida com a construção de relações cotidianas mais justas e dignas (Montero, 1994 a, 2000; Martín-Baró, 1989; Freitas, 1998b). Se pretendermos, hoje, pensar sobre as possibilidades de ação e de abrangência deste campo, como parte de uma reflexão sobre práxis e paradigmas, torna-se importante identificarmos os avanços obtidos e as dificuldades enfrentadas. Em outras palavras, ao enfrentarmos o debate a respeito da relação entre que conhecimentos socialmente relevantes temos produzido? versus que tipo de compromisso temos assumido e que alianças temos estabelecido? poderemos fazer um balanço sobre: a) os avanços das práticas psicossociais em comunidade na ótica dos setores envolvidos e da própria psicologia; b) o grau de ineditismo ou de conservadorismo das mesmas, e c) as lacunas existentes no processo de formação de profissionais para trabalharem nesse campo. Em decorrência, pretende-se, também, tecer

${ }^{1}$ Trabalho apresentado na Mesa Redonda "Psicologia Política: Paradigmas e Práxis" durante o IX Encontro da Regional SUL da Abrapso, acontecido em novembro de 2002, na UNIVALI/SC.

${ }^{2}$ Professora do Programa de Pós-Graduação em Educação e em Psicologia Universidade Federal do Paraná. algumas considerações sobre as aproximações necessárias entre campos disciplinares que podem se complementar, tanto na dimensão paradigmática como epistemológica. Este é o caso das Psicologias Política e Social Comunitária, da Pesquisa Participante e dos Movimentos Sociais, cuja intersecção pode gerar subprodutos para a dimensão da práxis, em termos de contribuir para o processo de formação de quadros para atuarem junto às políticas públicas (Freitas, 2001b; Sandoval, 2000; Scherer-Warren, 1999; Jacobi, 1989).

\section{Desafios para a construção de um campo teórico e profissional}

Após quase quatro décadas de trabalhos comunitários, desenvolvidos por profissionais de psicologia, devemos, então, nos perguntar: que avanços temos conseguido? e, houve mudanças, ao longo deste tempo? Inúmeros são os trabalhos que passaram a ser desenvolvidos, em especial ao longo dos anos da última década do século XX. Acompanhando uma dinâmica acontecida dentro dos movimentos sociais, vamos encontrando em diferentes lugares e em relação às mais variadas temáticas, diversos trabalhos comunitários realizados (Montero, 1994b; Freitas, 2000a, 2000b).

Podemos, então, nos indagar sobre os aspectos teóricos e conceituais que seriam necessários para que, de fato, possamos ter uma compreensão razoavelmente consensual sobre o que é e o que não é psicologia comunitária. E - aprofundando estas preocupações - que relações epistemológicas, teóricas e políticas deveriam existir entre os processos de intervenção psicossocial e as dinâmicas comunitárias para caracterizar esse tipo de prática?

Estes questionamentos nos remetem à necessidade de uma análise criteriosa sobre as diferentes conceituações e compreensões sobre o que é Psicologia Social Comunitária (Montero, 1994b, 2000; Freitas, 1998a). Existiu ou existe tal consenso de definição e conceituação ao longo da trajetória de construção deste campo? Que elementos poderiam explicar tais consensos ou diferenciações e o que isto implicaria em termos de consistência para este campo que vem se fortalecendo?

Podemos dizer que, hoje, temos uma gama significativa de práticas psicossociais em comunidade, indicando uma grande variedade de atuações, trabalhos e perspectivas epistemológicas (Gohn, 1987; Landim, 1998; 
Montero, 1994a; Freitas, 2000b). Tratam-se de práticas de intervenção ou atuação psicológica/psicossocial com características distintivas:

a. Dirigem-se aos mais diversos segmentos da população (como bairros; cortiços; favelas; mangues; alagados; diferentes grupos populares, civis, religiosos; diversos movimentos populares; segmentos ou setores de entidades civis, profissionais, comunitárias; comissões e/ou fóruns em educação, saúde, direitos humanos; entre outros);

b. Localizam o objeto de investigação e/ou ação dentro de um enquadre teórico diversificado (indo do individual, passando pelo familiar, por pequenos grupos, até organizações e movimentos comunitários e/ou populares de dimensões maiores);

c. Selecionam algum tema como central e prioritário em suas proposições (provenientes da área da saúde, educação, trabalho; relações comunitárias e organizativas; direitos humanos, violência e cidadania; formação profissional; qualidade de vida; relações de exclusão e inclusão social; emprego, desemprego e falta de perspectiva de vida, entre outros)

d. Empregam aportes teórico-metodológicos diferentes e, em algumas ocasiões, antagônicos entre si (podem se distribuir em um continuun em que em um dos pólos há a adoção de referenciais mais objetivistas, quantitativos e supostamente imparciais, e no outro extremo há, somente, a adoção de perspectivas analíticas qualitativas e participativas, excluindo qualquer tipo de recurso e/ou material quantitativo);

$e$. Estabelecem um tipo de relação de conhecimento entre o profissional e a comunidade que imprime rumos para o trabalho desenvolvido (o foco da decisão recai em um dos pólos da relação ou na síntese de ambos).

Assim, hoje, talvez fosse mais adequado nos referirmos a esse tipo de prática no plural, uma vez que há várias psicologias (sociais) comunitárias, e não apenas uma, e muito menos consensuais entre si, para não dizermos tendo concepções de homem e de sociedade, muitas vezes, díspares e antagônicas entre si.

Desta pluralidade de psicologias comunitárias depreende-se, também, um fenômeno interessante. Quando há 20 ou 30 anos, as práticas em comunidade eram pouco reconhecidas e identificadas como podendo ser do âmbito da psicologia, poucos eram os profissionais que gostariam, ou até mesmo buscavam ser incluídos neste campo. Com relação aos trabalhos que eram desenvolvidos àquela época poderíamos dizer que apresentavam uma similitude e proximidade maiores do que hoje, visto que haviam alguns eixos comuns em sua realização. Eram trabalhos que tinham grandes influências e recebiam orientações provenientes dos aportes teóricos e metodológicos derivados de: da Educação Popular e da Alfabetização de Adultos acontecida nos chamados países do Terceiro Mundo, como os trabalhos de Paulo Freire; das estratégias de trabalho com camponeses e suas organizações comunitárias, dentro de uma concepção participativa como os derivados da Sociologia Rural e de Orlando Fals Borda; e, das concepções de Homem, História e Sociedade oriundas do campo Marxiano (Flores Osório \& Gómez Jasso, 1999; Freitas, 2000b; Montero, 1996b; Martín-Baró, 1987, 1989).

Hoje, por outro lado, temos um movimento diferente com algumas características. Saímos de uma certa singularidade, presente há décadas, no que seria o trabalho psicológico em comunidade para uma grande pluralidade de práticas psicossociais em comunidade. Isto indica que diferentes abordagens teórico-metodológicas colocam como seu objeto de estudo o campo comunitário. Aqui, de imediato, já aparece uma primeira razão para a não concordância sobre o que define psicologia comunitária: encontra-se uma sinonímia de forma - todos empregam o termo comunitário ou seus correlatos; mas seu conteúdo, limites e características não têm uma base consensual.

Além disto, acredita-se que esta pluralidade deva ser analisada com seriedade e coragem, para que se possa saber se trata ou não de uma reedição de modelos psicológicos, anteriores e tradicionais, aplicados a novos contextos para os quais os psicólogos, na sua origem como ciência, não eram preparados. Em outras palavras, em algumas situações nos defrontamos com práticas psicológicas - tradicionais, com foco individualista e psicologizante - que acontecem junto a setores da população, antes distantes da psicologia, e em lugares nos quais o trabalho psicológico não ocorria. Somente isto não dá um caráter distinto e nem inédito à prática psicossocial. Hoje temos inúmeros trabalhos em Conselhos Tutelares, em Fóruns da Educação e da Saúde; em diversas instituições asilares, em ONGs, em sindicatos, em atividades junto aos portadores do HIV e de diferentes deficiências, junto ao MST e diferentes grupos e movimentos populares, entre outros. Como já dito, em outras ocasiões, por 
vários pesquisadores (Montero, 1994 a, 1994b, 2000; Freitas, 1998 a, 2000b, prelo; Yamamoto, 2000) — a proximidade às questões sociais e aos setores desfavorecidos, por si só, não garante uma mudança paradigmática e nem práxica do trabalho. Por outro lado, a reedição desta discussão, em especial, nos novos momentos político-sociais em que estamos a viver, depois que tomou posse um governo de origem popular, recoloca-nos o problema de ser necessária uma análise profunda a respeito das repercussões psicossociais, organizativas e políticas, para a comunidade, de serem desenvolvidos trabalhos preventivos versus trabalhos curativos, assim como aponta para a necessidade de serem identificados critérios para esta demarcação e escolha, de acordo com a situação a ser enfrentada (Lozada, 1999; Sandoval, 1994).

Apesar desta variedade de características, cujo cruzamento tece um leque imenso de possibilidades de trabalhos, podemos nos indagar se haveria algo de comum entre trabalhos tão diversos. A resposta seria afirmativa. Apesar da variabilidade das práticas e propostas de trabalhos podemos dizer que algo aproxima estes trabalhos, ou pelo menos estabelece algum tipo de liame entre eles, em especial a partir da década de 1990. Um elemento comum localiza-se no fato de que são trabalhos coletivos, com as mais diferentes perspectivas. Tratam-se de práticas realizadas junto a grupos e entidades comunitárias, a ONGs, sindicatos, Conselhos e conselheiros, entre outros. São trabalhos que, para sua realização, necessitam que o profissional saia do espaço tradicional e passe a se incorporar nos espaços e nas dinâmicas em que essas pessoas vivem ou atuam; além de também serem práticas dirigidas a grupos e relações coletivas e grupais (Freitas, 2001b).

Além disso, um aspecto positivo, a se ressaltar, refere-se ao fato de que passa a ser impensável desenvolver qualquer tipo de trabalho em psicologia que não leve em conta as problemáticas que assolam a maioria de nossa gente. Contudo, isto por si só não garante nem o aumento da participação e conscientização da população, em seus próprios processos cotidianos de sobrevivência e de melhoria de vida, e nem que o profissional de psicologia se identifique com tal empreitada ou considere que isto também seja de sua responsabilidade. Mesmo assim, esta proximidade ao cenário e à dinâmica sociais, como sendo uma dimensão que tem se mostrado frequente nos diferentes trabalhos desenvolvidos dentro e fora da academia, na área de comunitária, tem uma peculiar importância ao indicar duas situações cruciais. Uma, em que estampa para a psicologia comunitária e seus profissionais a necessidade de que conheçam as políticas públicas onde se inserem para que seus trabalhos possam apresentar coerências científicas e políticas. A outra situação aponta lacunas e deficiências no processo de formação dos quadros para esta área, em termos de domínio teórico e metodológico necessários, e de análise sobre as repercussões psicossociais das políticas públicas que permeiam as relações comunitárias cotidianas.

\section{Dimensões intrínsecas à Psicologia Social Comunitária}

A história da Psicologia Social Comunitária, no Brasil e na América Latina, permite que hoje tenhamos uma certa clareza quanto à compreensão do que a delimitaria como uma prática específica e com características próprias.

Necessariamente trata-se de um tipo de trabalho que vai para além da investigação, do estudo ou da análise teórica, como mecanismos essenciais em si. Estes são fundamentais e imprescindíveis, mas não completam a finalidade da psicologia social comunitária como prática, como conhecimento e como possibilidade de mudança. O outro pilar, também imprescindível, é o da intervenção ou ação psicossocial nas relações do cotidiano, entendida como uma forma de ação em que os agentes (internos e externos) se implicam numa relação partícipe e partilhada quanto à problematização da realidade e à elaboração de alternativas a serem implementadas, através de processos de formação e capacitação de lideranças e agentes comunitários, entre outras estratégias que têm se mostrado relevante (Freitas, 2001b; Montero, 1994 a, 2000).

Derivado disto, encontramos as origens teóricas e metodológicas que têm sustentado a realização destes trabalhos. As bases conceituais derivadas do campo Marxiano, da Sociologia Rural Crítica e da Psicologia Latinoamericana da Libertação orientam estas práticas, cujas estratégias metodológicas ancoram-se nos trabalhos da Educação Popular e de Adultos, dentro de uma Filosofia de Paulo Freire, assim como as práticas de Pesquisa Participante (ou investigação-ação-participante) e Pesquisa Ação, presentes nos trabalhos com os camponeses, como os movimentos sociais e populares 
das décadas de 60 e 70 no continente latino-americano, durante os períodos de ditadura militar (Freitas, 2000 b; Sandoval, 2000; Iglesias, 1993).

Após o período das dificuldades decorrentes da implementação de trabalhos dessa natureza, hoje, pode-se identificar, com uma certa clareza, uma dimensão intrínseca à filosofia e aos compromissos deste trabalho como tendo, inclusive, o status de categoria conceitual. Trata-se da dimensão sócio-histórica do homem, colocando-o como ator social e, também, à comunidade, como elementos centrais das relações comunitárias. Assim, a comunidade, através de tais trabalhos, ao longo destas últimas décadas, passa a ser vista como um ator social da própria história e trajetória, e cuja compreensão psicossocial torna-se decisiva para os avanços dos processos de participação e de conscientização (Freitas, prelo).

\section{Coerências e incoerências entre prática e compromisso}

Analisando-se as implicações psicossociais para a vida cotidiana dos trabalhadores comunitários envolvidos - profissionais e população - e para o próprio trabalho deparamo-nos com dois elementos que estão presentes e são intrínsecos à própria dinâmica do trabalho comunitário. Um deles liga-se à detecção e compreensão da dimensão sócio-política da ação humana e às repercussões psicossociais que tal ação passa a ter, seja para o psicólogo comunitário, seja para a comunidade (Freitas, 2001a; Montero, 2000). Trata-se de falar dos significados que a prática do trabalho, a cada etapa, tem para cada um dos atores envolvidos. Isto pode ajudar a entender os porquês de alguns avanços e retrocessos, mesmo quando parece que o trabalho já não possui mais nenhum impedimento para sua boa realização. $\mathrm{O}$ outro aspecto aponta para a natureza de comprometimento político e social do trabalho de intervenção psicossocial (Freitas, prelo). Isto nos remete a identificar que impactos e retornos este tipo de prática tem produzido e para que setores da população e dos participantes. Ao mesmo tempo, intentar responder a isto permite que se identifiquem dificuldades para esta consecução, assim como possíveis lacunas no processo de formação dos profissionais.

Voltamos à questão sobre se o que estamos fazendo em nossas práticas comunitárias traz impactos sociais relevantes e que postura profissional temos para obter isto?
Ou seja, será que em qualquer tipo de postura e concepção epistemológica seria possível obtermos os mesmos impactos? Ou, em outras palavras, qualquer recorte epistemológico e qualquer visão ontológica nos levariam aos mesmos impactos psicossociais na vida cotidiana? Embora este não seja o objetivo, aqui, esta consideração nos leva a enfrentar uma questão, sempre presente, que se refere à prática profissional, vista como ciência e produtora de conhecimentos, e concebida como profissão, no sentido de formadora de novos quadros para atuarem junto aos problemas sociais.

Retomamos, assim, aos desafios presentes nas três dimensões, indicadas ao início deste trabalho, e intimamente imbricadas quando do desenvolvimento das práticas em comunidade. Aquelas relativas ao tipo de práxis que é construído nos trabalhos comunitários, em termos de serem produzidos determinados impactos psicossociais na vida cotidiana das pessoas, implicando-as em processos de politização de sua consciência e de participação coletiva voltados para os interesses comuns (Sandoval, 2000; Freitas, prelo). Em outras palavras, trata-se de indagar sobre os resultados que temos conseguido, pontuais e a o longo prazo, e sobre que condições objetivas e subjetivas são necessárias para que as pessoas dêem continuidade ao seu processo de envolvimento e participação comunitárias. Os desafios da segunda e terceira dimensão referem-se às condições necessárias - seja em termos de realidade na qual se trabalha, seja em termos de formação epistemológica recebida — para que sejam produzidos e sistematizados conhecimentos a respeito do que seja considerado como comunitário, como psicológico e como uma relação psicossocial necessária entre os dois, conhecimentos esses que refletem o tipo de concepção a respeito do homem e da sociedade.

Tais desafios têm sido enfrentados ao longo dos inúmeros trabalhos que têm sido desenvolvidos, com os mais diversos matizes epistemológicos. Todavia, em todos eles tem se observado que o papel da Psicologia Social Comunitária tem sido o de educar e o de politizar. Educar nas relações concretas cotidianas e com um forte compromisso coletivo: por isto que as formas de ação comunitária presentes, por exemplo, nos trabalhos da educação popular e da pesquisa participante têm se revelado como imprescindíveis. A outra faceta do trabalho educativo, típico nas práticas psicossociais em comunidade, está na apreensão e construção de uma vida 
cotidiana fundamentada em valores de solidariedade, dignidade e justiça, com tolerância zero para os preconceitos e formas estigmatizadoras entre as pessoas. O papel de politizar refere-se às diferentes possibilidades de ação cotidiana que passam a ser incorporadas, não apenas em sua instrumentalidade, mas em seus significados psicossociais como catalisadores dos processos de conscientização para cada ator envolvido. Torna-se, então, imprescindível à psicologia social comunitária, nesta sua face ta da politização da consciência, a tarefa de construir sujeitos coletivos como atores da transformação social, forjada, desde já, nas relações cotidianas imediatas.

E, finalizando, gostaria de propor o desmonte de alguns mitos e maniqueísmos que acabam por criar armadilhas para possíveis demarcações entre as diversas práticas psicossociais em comunidade. Inegavelmente há uma grande contribuição para a relação Psicologia e Comunidade o fato de terem aumentado os projetos com temáticas sociais, mesmo que tenham diferentes epistemologias e concepções acerca da relação homem e sociedade, assim como impliquem em diversas propostas de resolução e enfrentamento de tais problemas.

Entretanto, considera-se que há, no mínimo, dois cuidados a serem tomados. O primeiro é que se deve evitar posturas que pretendam transformar todas as formas de ação, em contextos diferentes dos tradicionais, em práticas da psicologia comunitária. Fazer isto, no mínimo indica uma atitude simplista e subestimadora das diferenças e das especificidades das outras áreas, tão necessárias à compreensão do homem. $\mathrm{O}$ outro é que só haveria valor e importância em trabalhos com forte comprometimento social e político, simplesmente porque estariam a tratar de temáticas sociais. Há aqui uma delicada armadilha, visto que não é o cognome social, e nem temas ou objetos ligados a populações e setores desprivilegiados, que faz e garante com que o trabalho a ser realizado tenha um claro compromisso em prol da defesa dos direitos e da dignidade das pessoas. Por outro lado, também não é o fato do trabalho realizado ser dirigido a outros setores ou estratos da sociedade, que não sejam excluídos ou desprivilegiados, que lhe retira o caráter de implicação com a construção de uma vida solidária e mais justa. Tanto em um caso, quanto em outro, há ainda que se considerar que deveria haver aquilo que estamos a denominar de compromisso intrínseco. Em outras palavras, seja trabalhando com temáticas sociais altamente críticas, emergenciais e relevantes; seja trabalhando com outras dimensões cujas repercussões possam não ser diretamente captáveis, deve haver uma responsabilidade para com as possibilidades de produção de conhecimentos que façam avançar, melhorar e serem resolvidos aqueles problemas para os quais o profissional se debruçou.

Isto, em verdade, exige que sejam produzidos avanços no campo das produções científicas sobre o que se considera como comunitário e psicossocial no âmbito comunitário.

Estes parecem ser desafios que se apresentam ao processo de formação de novos quadros, nem sempre muito perceptíveis, e que podem nos colocar em contendas desnecessárias e pouco inteligentes para a área, para a psicologia e para a própria comunidade. Como vencer isto durante o processo de formação passa, então, a ser um grande desafio, que, no mínimo, exige que possamos garantir um bom aprendizado e domínio em análises consequentes sobre a realidade social, conjugando ao mesmo tempo o verbo da teoria e o da metodologia coerentemente construídas e em consonância ao objeto recortado pelo olhar epistemológico do trabalhador comunitário, sem deixar de, necessariamente, se implicar com a ética da vida cotidiana.

\section{Referências}

Flores Osório, J. M. \& Gómez Jasso, L. Y. (1999) Introducción a la Psicología Comunitária. CEDeFT, Cuernavaca, México.

Freitas, M. F. Q. (1998a). Novas Práticas e Velhos Olhares em Psicologia Comunitária. Uma Conciliação Possível? In L. Souza; M. F. Q. Freitas \& M.M.P.Rodrigues (orgs.) Psicologia: reflexões (im)pertinentes. São Paulo: Casa do Psicólogo, 83: 108.

Freitas, M. F. Q. (1998b). Models of Practice in Community in Brazil: Possibilities for the Psychology - Community Relationship. Journal of Community Psychology. 26(3): 261-268.

Freitas, M. F. Q. (2000a). O Movimento da Lente Focal na História Recente da Psicologia Social Latinoamericana. In P. A. Guareschi \& R. H. F. Campos (orgs.) Novos Paradigmas da Psicologia Social Latinoamericana. Vozes, Petrópolis, 167-185. 
Freitas, M. F. Q. (2000b) Voices From The Soul: The Construction of Brazilian Community Social Psychology. Journal of Community and Applied Social Psychology. Wiley Eds., Londres, 10:315-326.

Freitas, M. F. Q. (2000c) Lo Cotidiano em Las Prácticas de Psicología Comunitária. In J. J. Vázquez Ortega (coord.) Psicología Social y Liberación en América Latina. Casa Abierta Al Tiempo/UAM Iztapalapa, México, 199210.

Freitas, M. F. Q. (200la). Desafios e Possibilidades para a Psicologia Social Comunitária em Contextos Rurais. In H. A . Novo, L. Souza e A. N. Andrade (orgs.) Ética. Cidadania e Participação. Debates no Campo da Psicologia. CCHN, UFES, Vitória, 211-224.

Freitas, M. F. Q. (2001b). Psicologia Social Comunitária Latinoamericana: Algumas Aproximações e Intersecções com a Psicologia Política. Revista de Psicologia Política. SBPP, São Paulo, Vol. 1 (2): 73-94.

Jacobi,P. R. (1989) Movimentos Sociais e Políticas Públicas. Cortez Editora, São Paulo.

Gohn, M. G. (1997) Os Sem-Terra, ONGs e Cidadania. Cortez Editora: São Paulo.

Iglesias, F. 1993. Trajetória Política do Brasil. Companhia das Letras: São Paulo.

Landim, L. (org.) (1998) Ações em Sociedade. Militância, caridade, assistência, etc. Rio de Janeiro: Nau Editora.

Lozada, M. (1999) La Democracia Sospechosa: La Construcción del Colectivo en el Espacio Público. In G. A . Mota Botello (coord.), Psicología Política del Nuevo Siglo. Una Ventana a la Ciudadanía. México, SEP/SOMEPSO, 67-78.

Martín-Baró, I. (1987) El latino indolente. Carácter ideológico del fatalismo latinoamericano. In M. Montero (coord.) Psicología Política Latinoamericana. Caracas: Editorial Panapo, pp.35-162.

Martín-Baró, I. (1989) Sistema, Grupo y Poder - Psicología Social desde Centroamérica II. San Salvador: UCA Editores.
Montero, M.(1994a) Un Paradigma para La Psicología Social. Reflexiones desde el quehacer en America Latina. In M. Montero (org.) Construcción y Crítica de La Psicología Social. Barcelona: Editorial Anthropos, pp.27:48.

Montero, M. (1994b) Vidas Paralelas: Psicología Comunitária en Latinoamérica y en Estados Unidos. In M. Montero (org.) Psicología Social Comunitária-Teoría, método y experiencia. México: Universidad de Guadalajara, pp.1946.

Montero, M. (2000) Perspectivas y Retos de La Psicología de La Liberación. In J.J. Vázquez Ortega (coord.) Psicología Social y Liberación en América Latina. Casa Abierta Al Tiempo/UAM Iztapalapa, México, 9-26.

Sandoval, A .M. S. (1994) Algumas Reflexões sobre Cidadania e Formação de Consciência Política no Brasil. In M. J. P. Spink (org.), A Cidadania em Construção - Uma Reflexão Transdisciplinar. São Paulo: Cortez Editora, pp.59-74.

Sandoval, A. M. (2000) O que há de novo na Psicologia Social Latinoamericana? In R. H. F. Campos e P. A . Guareschi (orgs) Paradigmas em Psicologia Socia - A perspectiva Latinoamericana. Petrópolis, Vozes, pp.101109.

Scherer-Warren, Ilse (1999) Cidadania sem Fronteiras. Ações coletivas na era da Globalização. São Paulo: Ed. Hucitec.

Yamamoto, O. H. (2000) A psicologia Em Movimento: Entre o 'Gattopardismo' e o Neoliberalismo. Psicologia \& Sociedade, ABRAPSO, São Paulo, Vol. 12, N. 1/2: 221-233. 


\section{PSICOLOGIA E EDUCAÇÃO}

\section{A inclusão da pessoa com necessidades especiais na universidade: na perspectiva dos professores}

Lísia Regina Ferreira Michels ${ }^{1}$ Gabriela Andrea Díaz ${ }^{2}$

Falar em inclusão implica diretamente falar em exclusão, termo que, desde o ponto de vista social, abarca desde uma perspectiva ética, a análise da justiça social e do sofrimento humano.

De alguma maneira a sociedade sempre incluiu, ou melhor, inseriu, as pessoas com necessidades especiais, porém nem sempre esta inclusão se realiza de maneira democrática. Estar inserido não implica estar incluído. Sawaia (1999) propõe em vez da exclusão, uma relação dialética entre exclusão e inclusão que introduzirá à análise das desigualdades, uma visão ética e subjetiva, que deflagrará "subjetividades específicas que vão desde sentir-se incluído até sentir-se discriminado ou revoltado" (p.09).

Entendemos o processo de exclusão-inclusão como possuidor de uma dinâmica multifacética e complexa, em que a psicologia social tem um papel de importância fundamental na compreensão dos mecanismos que operam nesta dinâmica. Sob esta perspectiva, elaboramos um projeto de pesquisa com foco e metodologia determinados em função de um paradigma ético tendente a deflagrar estas operações.

Dentre nossos objetivos se inclui a necessidade de evidenciar que tipo de dinâmicas se operam tendentes à inclusão e quais se operam no sentido contrário, por isto o presente estudo, investiga a inclusão das pessoas com necessidades especiais na universidade, na perspectiva dos professores.

\footnotetext{
${ }^{1}$ Docente do Curso de Psicologia da Universidade do Vale do Itajaí - UNIVALI , Mestre em Psicologia PUCRS. Doutoranda em Psicologia da Educação - PUCSP.

${ }^{2}$ Acadêmica $-10^{\circ}$ Período de Psicologia na Universidade do Vale do Itajaí — UNIVALI - Bolsista do Programa de Iniciação Científica da UNIVALI.
}

Identificamos as diferentes estratégias que os professores utilizam para o atendimento dos estudantes com necessidades especiais $\mathrm{e}$ as dificuldades encontradas pelos alunos, na universidade. Foram sujeitos da pesquisa, 10 professores, de uma universidade do sul do país, que atuam diretamente com os alunos da graduação e que foram convidados a participar deste estudo.

A coleta de dados foi realizada através de entrevista semi-aberta. Para o procedimento de análise e interpretação de dados foi utilizado o método qualitativo, por meio da análise de conteúdo de Bardin (1991).

Além de identificar as diferentes estratégias utilizadas para o atendimento do aluno com necessidades especiais, os resultados indicaram algumas das dificuldades encontradas por estes alunos na universidade do ponto de vista dos professores. No estudo desta problemática pretendemos ampliar a discussão sobre a inclusão na universidade, o que poderá dar subsídios à elaboração de programas de atendimento a estes alunos neste âmbito educativo e, por conseguinte, na sociedade como um todo.

O Ministério de Educação e Cultura do Brasil (MEC) estima que existem 6 milhões de crianças e jovens até 19 anos com algum tipo de deficiência física ou mental no país. Somente 334,5 mil deles estão matriculados em escolas que oferecem atendimento para pessoas com necessidades especiais, o que significa que 5,7 milhões estão desassistidos, dados que nos levam a refletir sobre a urgente necessidade de inclusão dessa população.

\section{O professor e o aluno com necessidades especiais}

A exclusão explícita daquele que é diferente de algum modo presentifica uma outra exclusão, a do desejo: desejo de aprender, de ser, de ensinar, de criar. Ao excluir o aluno, o professor também se exclui e se aliena de si mesmo, de seus ideais, daquilo que se propôs realizar em seu trabalho (Valore, 1999, p.125).

Vash (1988) aponta que quando um aluno é matriculado, logo após surgem outros problemas: alguns professores se mostram relutantes a flexibilizar seus estilos de ensino para poder dar uma melhor acomodação aos alunos com necessidades especiais, muitos não estão dispostos a 
fornecer textos para os estudantes surdos ou permitir a gravação de aulas para os estudantes cegos.

Com respeito aos fatores potenciais para a marginalização Alcantud (1995), corrobora que, o aspecto físico das pessoas com necessidades especiais, é uma das características mais chamativas, além da falta de convívio e dos preconceitos e estereótipos.

Quanto às relações sociais, especificamente na relação com os docentes, Alcantud (1995) assinala que os professores frequentemente se sentem incomodados quando têm que atender alunos com necessidades especiais, provocando assim, discriminação. Também podem sentir que o fato de ter, na sala, um aluno com estas características, acarretará um trabalho adicional. Neste sentido, o autor faz referência a falta de pesquisa a respeito das atitudes e valores de professores e estudantes quanto a presença e companhia destes estudantes na sala de aula.

Quanto à formação dos professores Silva \& Mendes (1996) assinalam que o conceito de ser um bom professor esta relacionado com um investimento pessoal que deve ser assumido por cada pessoa, isto é, que deve ser resolvido ao longo da formação, em cada momento da vida.

Para a pedagogia moderna, segundo Mrech (1999), o aluno parece um ente abstrato, do qual basta saber como funciona em geral, para que nos forneça os dados de como ele se apresenta na prática. A crença é que o aluno, em geral, traz em seu bojo o aluno de uma forma específica ou particular (Mrech, 1999, p.5). Assim, a concepção teórica tradicional indicaria, então, que o aluno permanece inalterável no tempo e no espaço desde os primórdios até hoje. Por consequência, os professores adotam em suas práticas um modelo a-histórico e linear do processo educativo e do desenvolvimento do aluno, o que não facilita a percepção do aluno, em toda sua especificidade.

Segundo esta autora, a educação inclusiva nos leva a um questionamento em relação aos preconceitos e estereótipos através dos quais a realidade escolar é pensada. O problema não reside na culpabilização dos professores por acreditarem nas próprias imagens que eles possuem sobre os alunos, já que é a sociedade como um todo que estigmatiza e que continua a criar imagens estereotipadas, o que fica confirmado pelos índices de evasão e de repetência em todos os níveis de escolaridade.
Neste sentido, Mrech (1999) ressalta que não se trata só de saber como os professores devem ensinar, mas de um questionamento geral na ordem da ética.

De acordo com Cunha \& Leite (1996 p.15) o currículo constitui-se no "rol de conhecimentos e sua hierarquia na organização do saber que se veicula na universidade". Para os autores, são os conhecimentos organizados no currículo que favorecerão a preparação dos profissionais para o mercado de trabalho, objetivo que condiciona as decisões curriculares, as quais perdem sua autonomia entendendo que são historicamente dependentes das relações da educação com a produção e determinadas por elas.

Portanto "A educação tem por função estabelecer pontes entre as estruturas sociais e as estruturas de pensamento" (Cunha \& Leite, 1996, p.18). As autoras afirmam que existe uma estreita relação entre a forma e o conteúdo da educação e que esta se encontra estreitamente relacionada com o capital, relação que determina que o primeiro nível de decisão curricular esteja predeterminado, o que nem sempre é percebido, por estar fundado pela ideologia dominante.

Para estas autoras o conhecimento será transmitido por três instâncias fundamentais: currículo, pedagogia e avaliação. A primeira dirá qual conhecimento é válido, a segunda de que maneira transmiti-lo e a terceira qual a melhor realização deste conhecimento, porém a forma em que estes conhecimentos são transmitidos exerce o controle e o poder de distribuição.

Os professores são agentes ativos do processo de ensino/ aprendizagem, por isto é de fundamental importância que estes participem ativamente do processo de integração, recebendo toda a informação pertinente e o assessoramento específico sobre as características das pessoas a serem integradas.

É importante destacar, ressalta Alcantud (1995), que geralmente o pessoal docente da universidade encontra suas tarefas divididas, porque além da responsabilidade docente, deve também se ocupar de pesquisa e de tarefas administrativas, o que pode acarretar em uma sobrecarga de trabalho. Também acrescenta que o professor muito frequentemente encontra poucos recursos para adaptar sua exposição às turmas muito numerosas e sem recursos adequados. 
Mazzotta (2000) refere que a identificação das necessidades educativas especiais e as decisões a partir desta identificação, requer uma avaliação cuidadosa e criteriosa dos profissionais envolvidos, embora grande parte destas necessidades possam ser atendidas sem ações especiais e nas necessidades cujo atendimento por parte dos professores e recursos escolares comuns esteja além das condições e possibilidades, deverão ser viabilizados os atendimentos necessários nos âmbitos social, medico e outros, de forma direta ou cooperativa e integrada à educação escolar.

\section{Neste sentido, Mazzotta (2000) afirma que:}

É sabido que não são poucos os educandos que tem suas necessidades educacionais interpretadas como especiais ou muito diferentes por parte de professores mal preparados ou mal apoiados pelo sistema de ensino.

Michels (2000) ao analisar as condições pedagógicas da universidade afirma que tanto os alunos com necessidades especiais, como os que não tinham, referiram a necessidade de adaptar o sistema psicopedagógico ressaltando a falta de um centro de apoio específico com o qual a universidade demonstraria seu compromisso com a igualdade de oportunidades para todos os acadêmicos. A autora assinala também a necessidade de adaptação dos currículos, visando valorizar a diversidade e as capacidades de cada aluno e, para isto sugere propiciar o oferecimento de um núcleo de conteúdos comuns e mínimos, para assim evitar a segregação e atraso dos alunos. Merece importante destaque na pesquisa mencionada, a opinião que os alunos têm sobre o despreparo dos professores para o atendimento à população com necessidades especiais. Neste sentido, observa-se a falta de preparação dos cursos de capacitação, habilitação dos professores de Ensino Médio e Superior, já que não existem disciplinas orientadas a este efeito:

não existe a inclusão de disciplinas que discutam os aspectos psicopedagógicos, éticos e políticos da inclusão dos alunos portadores de necessidades especiais. Desta maneira, quando um professor se depara com um aluno diferente, ou seja, que necessite de uma avaliação diferenciada, ou material didático específico, não se mobiliza para atender, quer seja por desconhecimento, seja por preconceito (Michels, 2000, p.83).
Lacerda, Lemes, e Santos (2002) realizaram uma pesquisa na qual apresentam a preocupação existente com a formação (preparatória) dos professores para a inclusão de alunos com necessidades especiais.

O referido estudo foi realizado entre professores do Ensino Médio e Superior, levantando-se quais informações são ministradas nos cursos de formação em relação à educação especial e a inclusão de alunos com necessidades especiais.

Dentre os resultados os autores destacam que, no curso normal existe uma baixa quantidade de informações sobre inclusão e apenas os alunos que escolheram habilitação em educação especial possuem maiores informações.

Neste sentido Ambrogi, Moreira e Santos (2001) também relatam que:

Os professores têm receio em aceitar estas crianças em suas salas por se acharem incapazes de realizar um trabalho adequado com elas. Vê-se ainda que poucos são os professores especializados e que a maioria das escolas não contam com um suporte técnico para propiciar um atendimento integrado ao professor da classe comum, levando-o a estabelecer formas criativas de atuação com as crianças portadoras de necessidades especiais. $\mathrm{O}$ esforço realizado para integração do deficiente no Ensino Regular não vem surtindo o resultado esperado pelos organizadores, pela falta de preparo das Unidades Escolares para receber estes indivíduos (p.69).

Concordamos com Gadorti (1987) que

O profissional do ensino não é um técnico, um especialista, é antes de mais nada um profissional do humano, do social, do político (p.142).

\section{Nossa experiência de pesquisa}

Os dados coletados foram analisados qualitativamente, por meio da Análise de Conteúdo de Bardin (1988), em que foram criadas categorias e subcategorias com o objetivo de organizar os dados brutos para então interpretá-los globalmente.

A primeira categoria, denominada Identificação de dificuldades, agrupou a identificação das dificuldades do aluno pelo professor, assim como também as próprias dificuldades do professor para ministrar aula para $\mathrm{o}$ aluno com necessidades especiais. 
Em geral, os professores têm reconhecido algumas dificuldades dando mais ênfase à necessidade de acessibilidade em detrimento das dificuldades pedagógicas, as quais nem sempre são percebidas pelos professores e muitas vezes ignoradas. Um exemplo disso e a seguinte frase:

Ele não tinha nenhuma dificuldade, impressionante parece que o que faltou no olho foi para o universo, aquele em especial, não sei o que virá por ai.

Nesta categoria também, se colocam em lugar de destaque principalmente as barreiras de acessibilidade deixando-se de lado outro tipo de barreiras que dificultam a inclusão do aluno com necessidades especiais. A partir de algumas falas subentendeu-se que se existem rampas os problemas de acessibilidade e pedagógicos ficam completamente satisfeitos.

\section{Neste sentido destacamos a seguinte fala:}

Uma das primeiras coisas é o espaço físico, que agora por exemplo, nosso curso já melhorou um pouco porque tem uma entrada com passarela, com rampas.

Manzzoni, Torres e Oliveira (2001), entendem que o respeito à diversidade humana nos leva a verificar que todas as pessoas possuem habilidades diferentes, e que para desempenhar determinadas atividades algumas necessitam de condições especiais. Os autores entendem que a acessibilidade é parte constituinte das condições especiais as que as pessoas com necessidades especiais tem direito.

O conceito de acessibilidade tem origem, segundo relatam os referidos autores na década de 60, no advento do conceito (na área de arquitetura) de projetos livres de barreiras, o qual focava prioritariamente os problemas de circulação de usuários de cadeiras de rodas.

\begin{abstract}
A acessibilidade é um processo dinâmico, associado não só ao desenvolvimento tecnológico, mas principalmente ao desenvolvimento da sociedade. Uma sociedade que se preocupa em garantir às pessoas portadoras de deficiência o direito de participar da produção e disseminação do conhecimento certamente contará com a participação dessas pessoas, de forma ativa, em todos os demais setores da sociedade (Manzzoni, Torres et al, 2001, p.10).
\end{abstract}

Uma questão importante encontrada nas entrevistas foi a falta de reconhecimento da responsabilidade, sendo esta inerente ao cargo de professor, e sim própria da universidade a qual, segundo as falas recolhidas, deveria dar os subsídios pertinentes para que o professor possa ministrar aula para todos seus alunos, independentemente das diferenças que estes apresentam: surdo?

Não, nunca pensei nisso... teria que aprender a falar com as mãos.. isso aí eu acho que a universidade teria que me propiciar.

Outros professores referiram não ter dificuldades, porém, nem sempre os alunos com necessidades especiais se manifestam a respeito de suas necessidades:

...eu particularmente não tive nenhuma dificuldade, eu me dei assim super bem entende? Acho também que eles não reclamaram eu procurei entender né?

Reconheceram as próprias dificuldades em ministrar aula por desconhecer as técnicas apropriadas, o que redunda em uma completa falta de estratégias propiciadoras da inclusão desses alunos.

Outra das categorias elaboradas, intitulada As Estratégias, resume a maneira que os professores encontram para lidar com estes alunos.

É interessante ressaltar que alguns entrevistados não referiram ter dificuldades para ministrar aula aos alunos com necessidades especiais, porém, quando indagados sobre que estratégias utilizariam, demonstraram não possuir conhecimentos sobre as melhores formas de lidar com estes alunos e trabalhariam movidos por improvisação que, sendo ainda uma alternativa (talvez a única possível) não é a mais indicada ou favorecedora de uma real inclusão.

Em geral, reconhecem e admitem não saber como lidar com uma pessoa com necessidades especiais dentro da sala de aula:

Olha, eu acho que é mais o visual mesmo, até porque eu não me considero a pessoa mais apta para lidar com ele, a única coisa que eu posso é sempre perguntar se está legal, mais eu não tenho uma técnica eu não tenho material, eu não sei lidar com Braille, eu não sei né?

Manifestaram em geral acreditar possuir maiores dificuldades com alunos surdos: 
é um problema, porque o cego ele ainda tem a possibilidade da audição né, agora o surdo... não sei. Se aparece uma pessoa com falta de audição dentro da sala de aula, como é que eu devo proceder? Não faço nem ideia...

Os entrevistados demonstraram, em geral, desconhecer quais as estratégias específicas poderiam favorecer a inclusão do aluno com necessidades especiais na universidade, como também reconheceram não ter tido nenhuma formação para lidar com estes alunos e tentam elaborar estratégias a partir da improvisação no chute. Professores que ainda não passaram pela experiência de ministrar aula para estes alunos, e nunca pensaram nessa possibilidade, teriam que inventar o que denota mais uma vez a falta de informação e formação específica a este respeito. As seguintes falas refletem este desconhecimento:

Eu não saberia como fazer exatamente, mas eu acho que teria uma inspiração de momento..

É mesmo, nós os professores, não estamos preparados para trabalhar alunos que tenham deficiência visual, por exemplo, nós não temos técnicas para trabalhar, nós não conhecemos, nós improvisamos às vezes dá certo, às vezes não.

Nunca tive contato com este tipo de aluno e também, sinceramente, não estaria preparado, tecnicamente preparado, para receber este tipo de aluno.

Não ministro diferente porque não sei, não tenho conhecimentos, precisava fazer um curso para saber, sim, maneiras diferentes de trabalhar.

Uma outra categoria que merece destaque é o Preconceito que foi manifestado de maneira direta ou encoberta por uma atitude paternalista.

Johnson (1997) define o preconceito como:

Atitude cultural positiva ou negativa dirigida a membros de um grupo ou categoria social. Como uma atitude, combina crenças e juízos de valor com predisposições emocionais positivas ou negativas (p.180).

Este autor também refere que o preconceito fundamenta a discriminação e o tratamento desigual para determinados indivíduos pertencentes a um grupo ou categoria.
As vezes o preconceito não se manifesta abertamente senão de maneira velada, porém, acaba constituindo do mesmo modo um ato de discriminação. De alguma forma todas as pessoas sabem que não podem se apresentar pré-conceituosas, o politicamente correto é não ter preconceitos, porém, estes aparecem de qualquer forma e quando negados ou supostamente ocultos, muito mais difíceis de vencer. Pareceria ser também, através da analise das falas de alguns entrevistados, que existisse um sentimento de menos-valia para com o aluno com necessidades especiais o que se converte em discriminação:

Não fiz nada, nenhuma, diferença, até porque eu acho que não tem que fazer diferença, senão é paternalismo.

Quando o entrevistado fala em "Não fazer diferença", nega a diferença, que não pode ser negada, ela existe sempre entre todos os seres humanos, portanto não fazer diferença é uma maneira de não atender às necessidades que se apresentam de forma diferente para cada aluno e mais especialmente para o aluno com necessidades especiais .

...não tem que criar diferença, ta, porque senão vou criar privilégios, de fazer a prova em casa ou fazer isto... porque o outro não pode fazer é privilegio, então é óbvio que a coisa é muito tênue né, é claro que eu tenho que ter um cuidado especial com essas pessoas, mas eu também não posso criar uma própria discriminação com elas para com os outros né, dar um tratamento diferenciado de queridinho tarará, faz teu trabalho em casa tudo em casa, não sei o que, não sei o que se os outros não tem o mesmo direito, então na verdade estou discriminando da mesma forma.

Ter atitudes paternalistas com certeza é absolutamente contraditório ao conceito de inclusão que acreditamos ser necessário para uma sociedade mais justa e equitativa, porém dito conceito necessita ser compreendido em toda sua extensão, incluir significa atender as necessidades especiais que cada pessoa possui.

Muitas vezes, ao contrário do destacado anteriormente, se incorre em atitudes paternalistas, que de alguma maneira pareceria a consideração em demasia da deficiência, a pessoa com necessidades especiais acaba sendo "portadora" de uma suposta inutilidade que será suprida por muita força de vontade. Falamos aqui de uma igualdade de direitos e obrigações que é de fundamental necessidade, falamos aqui, de uma igualdade na diferença. 
Assim, constatamos manifestações de assistencialismo, evidenciadas por atitudes superprotetoras. Por exemplo:

Suprem com essa força de vontade né?

A deficiência existe de qualquer forma e não tem como supri-la, é nossa obrigação fornecer os recursos necessários para que não deva existir força de vontade a mais, senão a mesma que todos os alunos possuem:

A gente tem aquele carinho especial por aquele aluno né,... parece que eles suprem eles tem assim uma atenção muito legal...

Ele não tinha um tratamento especial o único tratamento é que e... eu tinha que ver por ele... eu tinha que traduzir pra ele quando tinha algum detalhe que ele precisaria imaginar né eu tinha que fazer isso por ele.

Você não muda essa realidade, você não tem como mudar essa realidade... a gente tenta desenvolver um trabalho que amenize ou que dê as condições dele se desenvolver né...

O trabalho a ser desenvolvido não é o de amenizar, minimizar as diferenças, senão de fornecer subsídios, assim podemos sim mudar a realidade, igualando as oportunidades. Consideramos que o desenvolvimento humano não tem limites.

Os próprios alunos discriminam principalmente se o deficiente é capaz, se ele demonstra capacidade;

O pessoal da sala começou a discriminar ele por que achou que os professores o estavam protegendo.

Neste sentido consideramos de fundamental importância a atitude inclusiva que o professor deve ter em sala de aula, lugar propício para o diálogo entre os alunos e que poderá produzir mudanças no pensamento de todos contribuindo assim a tornar uma sociedade melhor e acolhedora da diferença.

Como eles são minoria não tem um movimento muito forte né, alguém que se responsabilizasse.

Também de acordo com as possibilidades dele né, porque eu vou ter que atender as características individuais dele e é lógico, a gente vai ter que atender dentro do processo que ele conseguir aprofundar porque vai ter que atender essas características.
O professor deve adaptar sua aula para que o aluno com necessidades especiais consiga atingir as mesmas metas que os outros alunos, aqui parece que se equipara uma deficiência física com uma deficiência mental.

A modo de consideração final, entendemos a partir do estudo realizado, que a inclusão na universidade é um tema muito vasto e que não se esgota em si mesmo. Serão necessários outros estudos para a compreensão deste fenômeno, e fundamentalmente é urgente a mudança de atitudes frente a pessoa com necessidades especiais, para poder mudar de alguma maneira a realidade vivida pelos alunos com necessidades especiais e propiciar uma educação de qualidade para todos.

Entendemos que, de maneira geral, a forma dos professores lidarem com os alunos com necessidades especiais é muito limitada e, como foi destacado, parte da improvisação e não de conhecimentos específicos, por isto recomendamos o debate e discussão de temas e assuntos relativos à educação inclusiva nos cursos de capacitação e atualização docente ministrados na universidade.

Verificamos que as dificuldades enfrentadas pelos alunos com necessidades especiais na universidade, nem sempre são reconhecidas pelos professores e que aparentemente segundo sua percepção estas se resumem basicamente a dificuldades na acessibilidade e que outras dificuldades que tangem especificamente a aspectos pedagógicos ficam sem atendimento.

Alguns professores utilizam estratégias para favorecer a inclusão, porém, quase sempre estas partem do senso comum ou de improvisações, o que nem sempre determina uma real inclusão destes alunos.

Os professores entrevistados reconheceram, em geral, não possuírem conhecimentos necessários para lidar com alunos com necessidades especiais, seja pela falta de experiência ou convívio ou por falta de formação específica, o que acaba redundando em atitudes discriminatórias, preconceituosas ou paternalistas

Entendemos que a formação dos professores pouco aborda os aspectos referentes à educação inclusiva, não há disciplinas específicas nos cursos de graduação, de pós-graduação, nas licenciaturas ou mestrados e não são estas que preparam os professores universitários? Para que alunos são preparados estes professores? Parece-nos que só para ensinar para aos 
"iguais". Neste sentido, apontamos a necessidade urgente e importante de esclarecimentos sobre este tema.

Este estudo tem servido para ampliar nossos conhecimentos sobre educação inclusiva e, poderá ser uma ferramenta utilizada para gerar recursos tendentes a uma real inclusão social. Sabemos que o caminho da inclusão é longo, porém, indispensável para uma sociedade mais justa e igualitária.

\section{Referências}

Alcantud, F. (1995) Estudiantes con discapacidades integrados en los estudios universitarios: notas para su orientación. In: Manual de Asesoramiento y orientación vocacional. Editor: Francisco Rivas. Editorial Síntesis. Barcelona. 457-469 p.

Ambrogi, D; Moreira, M. c., Santos, J. A, Santos, S. M. L., Vargas, A M. R, Takaki, D. (2001) Depto. de Pedagogia - UNITAU. Disponível em: http://www.unitau.br/prppq/inicient/iveic/resuhuma/huma02.htm

Bardin, L. (1991) Análise de Conteúdo. Lisboa: Edições 70.

Cunha, M. I. da. \& Leite, D. B. C (1996). Decisões pedagógicas e estruturas de poder na universidade. Campinas, SP: Papirus.

Gadotti, M. (1987) Concepção dialética da educação: um estudo introdutório. São Paulo: Cortez.

Johnson, A G. (1997) Dicionário de sociologia: Guia prático da linguagem sociológica. Rio de Janeiro: Jorge Zahar Ed.

Lacerda, P. G., Lemes, R M. R, Santos, R A (2002) Depto. de Pedagogia. http://www.unitau.br/prppg/inicient/iveic/resuhuma/huma02.htm

Mazzoni, A A, Torres, E. F., Oliveira, R de et al. Aspectos que interferem na construção da acessibilidade em bibliotecas universitárias. Ci. Inf. [online]. Mai./ago. 2001, vol.30, $\mathrm{n}^{\circ} 2$ [acessado em 29 Agosto 2002], p.29-34. Disponível em: http://www.scielo.br/scielo.php

Mazzotta, M. J. S. (1996) Educação Especial no Brasil: História e políticas públicas. São Paulo: Cortez.
Michels, L.RF. (2000) A Inclusão/ Exclusão da Pessoa Portadora de Necessidades Especiais no Contexto Universitário. Dissertação de Mestrado. PUCRS.

Mrech, L. M. (1999) Psicanálise e educação: novos operadores de leitura. São Paulo: Pioneira.

Silva, M. H. L. D. \& Mendes, M. T. P. J. (1996) Textos e contextos: contributos para novas práticas na formação inicial de professores. In: II Congresso Galaico-Português de Psicopedagogia. Almeida \& Silvério \& Araújo (Org.). Braga: Universidade do Minho, 105-112 p.

Sawaia, B. (1999) Introdução: Exclusão ou Inclusão perversa? In: As Artimanhas da Exclusão: análise psicossocial e ética da desigualdade social. Org. Bader Sawaia. Petrópolis: Vozes, 7 p.

Valore, L. A (1999) Contribuições da psicologia institucional ao exercício da autonomia na escola. In: SILVEIRA, A F. et al. Cidadania e participação social. Porto Alegre ABRAPSOSUL, 119-128 p.

Vash, C. L. (1988) Enfrentando a deficiência: a manifestação, a psicologia, a reabilitação. São Paulo: Pioneira — Editora da Universidade de São Paulo. 


\section{Dialogando com o diferente: a convivência e a pluralidade cultural ${ }^{1}$}

Ana Pagamunici $i^{2}$

Neste artigo, abordaremos a identidade e alteridade num contexto de pluralidade cultural, enfocando a necessidade e as possibilidades de se estabelecer um diálogo entre diferentes manifestações grupais, a fim de que o contato com aquele que consideramos "diferente" se constitua em um espaço para que conheçamos o outro a partir de sua especificidade e reconheçamos, a partir das divergências, nossa identidade.

$\mathrm{Na}$ sociedade capitalista neoliberal, de acordo com Adorno e Horkheimer (1995), os meios de divulgação da cultura transformaram-se em uma indústria de massa que tem por função oferecer e vender produtos que criam a sensação de que todos somos iguais e que há uma cultura hegemônica, globalizada e mundial.

Este discurso falacioso, que esconde por trás de si um projeto imperialista de recolonização dos países pauperizados, traz a ideia de que há somente um pensamento, uma maneira de viver, já que todos somos universais. As diferenças locais ou regionais parecem não ser importantes e a diversidade entre grupos próximos deve ser homogeneizada em prol da globalização mundial. O "outro", nesta perspectiva, segundo Jovchelovitch (1999), é sempre aquele muito distante de nós, que não faz parte de nosso convívio.

$\mathrm{Na}$ sociedade capitalista atual, a diferença aparece como algo existente em um espaço distante, longínquo e, quem sabe, inalcançável: por exemplo, índios ou populações já extintas. A diferença próxima (aquela que se dá no seio de um grupo) é negligenciada, insignificante e desconsiderável, o que cria um clima de que todos somos iguais e sobressai a ideia de que o outro é sempre aquele que está longe ou que se opõe.

${ }^{1}$ Este artigo é fruto da produção teórica de material utilizado na assessoria de um curso popular de formação de lideranças, numa comunidade religiosa da cidade de Santa Izabel do Ivaí-PR. A elaboração final do material contou com a colaboração da Professora de Psicologia Social, Suzana Maria Lucas Chaves e do estudante de Psicologia, Durval Wanderbroock Junior.

${ }^{2}$ Educadora de base do Centro de Referência da Criança e do Adolescente de Maringá.
Porém, sabemos que isso não é verdade, que as diferenças também se manifestam dentro de um mesmo grupo e, a todo o momento, expressam-se na diversidade cultural. Isso nos leva a indagar: quem é aquele que chamamos de "outro"? Quem e o que é o diferente? O que configura a diferença?

Para responder a essas questões, temos que, inicialmente, entender o que estamos chamando de pluralidade cultural.

De acordo com Arendt (apud Jovchelovitch, 1999, p.75), a pluralidade é a "diversidade infinita de perspectivas diferentes e únicas produzidas pela interação entre os homens". Além disso, a pluralidade é o que confere aos homens a sua condição de humano:

(...) a pluralidade dos seres únicos é o que caracteriza a condição humana; nós somos seres únicos e por isso nós somos plurais. E essa unicidade que garante a pluralidade (Arendt, apud Jovchelovitch, 2000, p.44).

Compartilhando dessa definição, S.M. Lucas-Chaves (comunicação pessoal, 12 de Agosto de 2002), explica que pluralidade de um grupo não está somente na convivência entre diferenças e semelhanças, mas nas “(...) interconexões dinâmicas criadas pelo grupo, através de seus integrantes, e estabelecidas entre semelhanças e diferenças".

Quanto à cultura, Thomaz (1995, p.427) escreve que

(...) se refere à capacidade que os seres humanos têm de dar significado às suas ações e ao mundo que os rodeia. A cultura é compartilhada pelos indivíduos de um determinado grupo, não se referindo pois a um fenômeno individual; por outro lado (...) cada grupo de seres humanos, em diferentes épocas e lugares dá diferentes significados a coisas e passagens da vida aparentemente semelhantes.

Nesse sentido, a cultura é um código simbólico construído e criado, a cada dia, na convivência dos povos e que é compartilhado pelos integrantes de um determinado grupo social. Isto porque, o homem é um ser social (compartilha com outros homens formas de agir e pensar) e não é um ser passivo, ao contrário, constrói ativamente os significados a partir das interconexões entre as diversas relações que estabelece durante sua existência. 
Esta construção, segundo Thomaz (1995), faz parte de um aprendizado humano, adquirido na convivência com os outros, de forma que pertencer a uma determinada cultura significa aprender, ou seja, "a cultura se refere, pois, à capacidade - e necessidade - que os seres humanos têm de aprender" (Thomaz, 1995, p.428).

Tendo esclarecido isso, tentaremos responder às perguntas anteriormente levantadas.

De acordo com Arruda (1999) a diferença tanto pode aproximar como distanciar grupos. Ela não depende apenas do "outro", pois ele não é somente aquilo que nos é apresentado, mas a representação que fazemos dele.

As comidas típicas, as práticas para aquisição de alimentos e manutenção da vida, os rituais sagrados, as roupas, os costumes formam o que chamamos de manifestações culturais. A cultura compreende essas manifestações adicionadas do simbolismo que o coletivo cria a partir disso, ou seja, o elemento simbólico criado a partir da prática, que está situada historicamente, em um determinado espaço e tempo. Portanto, que expressa e traz consigo características de um determinado contexto histórico.

É esse contexto histórico que diferenciará o "outro" e o "mesmo", pois eles são mutáveis ao longo da história. Ora o mesmo pode ser o "outro", ora o "outro" pode ser o "mesmo", pois “o ‘outro' e o ‘mesmo' são uma construção recíproca que se desvela ao longo de situações históricas" (Arruda, 1999, p.18).

E no espaço em que se encontram o "mesmo" e o "outro" que devemos pensar a diferença e a alteridade. Segundo Jodelet (1999) a alteridade é o espaço da diferença elaborada: a condição do "outro". E um processo que só se dá numa sociedade plural, que evoca, ao mesmo tempo, pluralidade e identidade. Ela é construída num espaço de produção e exclusão, pois se configura no entendimento e reconhecimento do "outro", ao mesmo tempo em que faz a exclusão desse "outro", reafirmando a identidade: individual ou grupal.

\section{Para Jodelet (1999, p.47),}

a noção de alteridade é sempre colocada em contraponto: "não eu" de um "eu", "outro" de um "mesmo". Ela faz par filosoficamente, com a noção de ipseidade - caráter que faz com que o indivíduo seja ele- mesmo e distinto de todos os outros; remetendo a uma distinção antropologicamente originária e fundamental - a distinção entre o mesmo e o outro - ela estabelece, de saída, uma relação de identidade...

Baseada na teoria piagetiana, Jovchelovitch (1999) afirma que a alteridade é o elemento indispensável para que o sujeito se reconheça no mundo e construa sua identidade; para que reconheça a presença do "outro" (entendido como objeto do conhecimento), ${ }^{3}$ pois é a partir do reconhecimento do "outro" e do simbolismo, criado a partir desse reconhecimento, que o homem é capaz de construir sua identidade e se reafirmar no mundo.

Como uma via de mão-dupla, a alteridade é um processo que se sustenta no nível das representações, forma-se no processo de interação entre os diferentes, a partir dos símbolos que se criam nessa relação.

Para melhor entender o conceito de alteridade, Jodelet (1999) faz a diferenciação entre "alteridade de fora" e "alteridade de dentro".

A "alteridade de fora" refere-se "ao "longínquo" e "exótico" definidos com relação a uma cultura dada - seja ela nacional, científica ou grupal (Jodelet, 1999, p.48). A "alteridade de dentro" "refere-se àqueles que, marcados com o selo da diferença, seja ela física (cor, raça, deficiência, etc.) ou ligada a uma pertença de grupo (nacional, étnico, comunitário, religioso, etc.) se distinguem no seio de um conjunto social ou cultural e podem aí ser considerados como fonte de mal-estar e ameaça" (Jodelet, 1999, p.48)

Durante muito tempo, o problema da alteridade na antropologia ficou restrito à "alteridade de fora". A preocupação das ciências sociais era apenas identificar os fenômenos coletivos que se distinguiam entre uma cultura próxima e outra muito distante, $\mathrm{O}$ que resultou no equivocado entendimento de que a alteridade se refere apenas à diferença entre o "mesmo" e o "outro".

${ }^{3}$ Dizer que o "outro" é objeto de conhecimento, para Jovchelovitch (1999, p.69), significa dizer que este " (...) refere-se a objetos humanos e não-humanos, uma vez que eles se tornam reconhecidos como objetos de conhecimento (...) refere-se a tudo que se torna objeto do conhecimento, incluindo, é claro, o momento em que o eu torna-se um objeto para si mesmo (...) sem o reconhecimento do outro, a produção do sentido e seus correlatos - a forma simbólica, a linguagem e as identidades — seriam inexistentes". 
A partir das teorias freudiana e marxista, a "alteridade de dentro" assumiu destaque nos estudos sociológicos e a problemática da diferença começou a ser estudada dentro do próprio grupo.

A alteridade, produzida a partir dessas diferenças torna-se objeto de estudo da Psicologia, que não se limita a estudar a relação entre o "eu" e o "outro", partindo do individual e ignorando o contexto, mas que busca neste próprio contexto o lugar da diferença e, por consequência, da alteridade.

Para Jodelet (1999, p.52) o que nos interessa saber, portanto, é como alguém próximo se torna o outro. Sabemos, através da psicologia, que o processo de diferenciação é a base do funcionamento mental, o que nos urge perguntar: "quando e como a diferença - entendida como oposição distintiva em que os contrários se unem - se transforma em ruptura entre duas entidades distintas?". É a própria autora que responde, escrevendo que essa passagem se dá no social que oferece um enorme palco de elementos simbólicos e práticos que fornecerão a transformação à alteridade.

Guareschi (1999a) nos dá um alento com relação ao outro e ao espaço da diferença. Ele diz que o homem possui singularidade e subjetividade. Então, para o autor (p.153-154), "a singularidade (dimensão do ser humano enquanto é um ser único, irrepetível, absolutamente singular) é o que nos confere a diferença, que nos dá a condição de diferente". A subjetividade ("conteúdo" do nosso ser) nos mostra que também somos os outros, pois nos constituímos a partir das relações que estabelecemos durante toda nossa vida com os outros do mundo. Assim, o espaço da alteridade e da diferença está na relação, tanto do próprio ser que conjuga muitos outros em si, quanto no encontro entre outros que entram em relação.

Jovchelovitch (1999) escreve que a noção de alteridade se desenvolve desde que somos criança e que o "outro" na construção de nossa identidade tem papel fundamental, já que ela se forma numa relação intersubjetiva.

E a intersubjetividade que, de um lado, permite a existência do ato significante, ao mesmo tempo que, de outro lado, previne o totalitarismo de interpretações simbólicas que se propõem únicas, ou capazes de exaurir o objeto com a versão que propõem (Jovchelovitch, 1999, p.70)
Dessa forma, "a identidade e a diferença não são termos alternativos e sim pensados um em função do outro, em mútua dependência" (Perrot, apud Arruda, 1999, p.17).

Já vimos que a alteridade se dá no plano da representação, o que queremos acrescentar é que o homem se reconhece e reconhece o mundo pela representação produzida a partir de algo concreto do mundo (símbolo). Essa representação adquire força porque produz um sentido.

Este não é uma entidade descolada do mundo; refere-se sempre a alguma coisa fora de si, ou seja, a um objeto e nasce pela ação de um ser humano. Sentidos têm o poder de referir e expressar (Jovchelovitch, 1999, p.71).

O símbolo existe a partir do momento em que o indivíduo é capaz de perceber que os objetos existem além de sua atividade. Sendo assim, a "possibilidade lógica para a existência do ato significativo é a consciência de um objeto-mundo que existe para mais além da atividade do sujeito" (Jovchelovitch, 1999, p.71). Esse objeto-mundo é o que poderíamos, inicialmente, chamar de "outro", pois ele mostra que a presença do homem não é única no mundo, comportando-se como um parâmetro para a construção da identidade.

Segundo Jovchelovitch (1999) num mundo em que o indivíduo não reconhece outros objetos, jamais poderá reconhecer a si mesmo, pois quanto mais permanece centrado em si, menos é capaz de olhar ao seu redor se reconhecer a partir dos elementos externos que lhe diferenciam. À medida que o sujeito reconhece os objetos do mundo, ele estabelece uma relação com esse mundo: deixa de ser um objeto inerte, passivo e passa a se reconhecer como um ser atuante, capaz de intervir e modificar o meio em que vive.

Esta relação, segundo Jovchelovitch (2000, p.21-22), não se estabelece apenas entre o sujeito e o objeto, mas é mediada. Isto porque, “o outro é tanto o meu Outro, significativo que está comigo aqui e agora, como é o Outro generalizado, simbólico, é um Outro da cultura generalizado".

Sendo assim, ao buscar o outro, acabamos por nos reconhecer, acabamos percebendo que o outro não é somente aquilo que está longe, mas também, parte daquilo que pertence a nós. Nesta perspectiva, a identidade é construída a partir da relação do indivíduo com o mundo e mediada pelos sujeitos desse mundo. 
Inicialmente, a criança se percebe como um objeto do mundo. Ao entrar em contato com a alteridade deste, percebe-se como um objeto que também produz saber, ou seja, percebe-se como um sujeito no mundo capaz de modificá-lo a partir de seu saber. De objeto do mundo, ela passa para constituinte do mundo e das ações que lhe rodeiam. Daí surge a capacidade para representar, para evocar o objeto que não se encontra perto, para dar distância e diferença do mundo, o sentido e a proximidade que o fato psíquico constrói, desse surgem: o reconhecimento de si e do mundo.

Nesse reconhecimento, o símbolo e o sentido que criamos para um determinado objeto possui papel muito importante: evidencia que a relação e o significado atribuído às coisas são formados num processo de interação (uma relação entre o eu e o outro) e cooperação com o diferente, numa relação de compromisso com esse diferente, que não se apresenta a nós, mas que o buscamos, a partir de nosso desejo e de nossa necessidade, advinda das relações sociais e coletivas. Desejo esse que não é imanente ao indivíduo, mas que está, certamente, influenciado pelas as relações sociais e necessidades de conhecer o mundo e se reconhecer.

Relacionar-se com a diferença envolve desejo, e é a natureza dessa condição desejante que também define a forma como uma sociedade se engaja na rede de relações humanas que permite tanto a construção dos saberes como dos sentidos, eles próprios são atividades cruciais para sustentar a formação de identidades, sentimentos de pertença e o sentido de comunidade (Duveen, 1999, p.74).

Entender como se forma a identidade e o conhecimento dos objetos do mundo é muito importante para verificarmos como em nossa sociedade atual o sujeito do saber não encontra mais espaço.

Conforme Adorno e Horkheimer (1995), os meios de comunicação de massa, sobretudo a televisão, oferece-nos todos os objetos do mundo, que nos é externo, prontos: o novo é apresentado, juntamente com as conclusões a respeito desse.

Os críticos são os grandes representantes de nosso pensamento. Aquilo que deveríamos fazer ao nos depararmos com um novo objeto: reconhecê-lo e criar um sentido para o reconhecido está sendo negligenciado, concomitante, à capacidade intelectual: não precisamos mais pensar diante do novo, isso faz com que não entremos em relação com ele e não nos diferenciemos no mundo. Estamos, cada vez mais, fadados a não nos reconhecermos, pois não estamos percebendo a diferença, não estamos entrando em relação com o outro na sua forma original. $O$ sentido que temos das coisas é o sentido oferecido pela propaganda.

Relacionado a isso, há outro agravante: não reconhecendo os objetos do mundo, acabamos por nos fechar em nós mesmos, em acreditarmos que nos tornarmos o centro do mundo. O que é muito complicado, pois, como disse Piaget (apud Jovchelovitch, 1999, p.72), é precisamente "quando o sujeito está mais autocentrado, que ele menos conhece a si mesmo". Permanecendo desta maneira, não construiremos nossa identidade, não nos diferenciaremos do mundo, assumiremos a identidade que nos é oferecida pela concepção de homem do sistema capitalista neoliberal.

Uma identidade que não possibilitará nos reconhecermos como sujeitos humanos, pois, conforme escreve Ciampa (1995, p.72)

a tendência geral do capitalismo é constituir o homem como mero suporte do capital que o determina, negando-o, enquanto homem, já que se torna algo coisificado (torna-se trabalhador-mercadoria e não trabalha autonomamente; torna-se capitalista-propriedade do capital e não proprietário das coisas).

Daquilo que expusemos, podemos dizer que, primeiro, a identidade é um processo; segundo, que é construída a partir de relações práticas que estabelecemos num espaço social, que é caracterizado historicamente.

Ciampa explica que essas relações, ao mesmo tempo em que nos diferencia, nos iguala - por exemplo, "nosso primeiro nome (prenome) nos diferencia de nossos familiares, enquanto o último nome (sobrenome) nos iguala a eles" (1995, p.63) — de modo que a identidade incorpora tanto a diferença como a igualdade.

À medida que vamos estabelecendo relações ao longo de nossas vidas, vamos nos igualando e diferenciando. O espaço social que inicialmente é a família passa posteriormente para os grupos dos quais faremos parte e que constituirão nossa identidade. Dessa maneira, "o conhecimento de si é dado pelo reconhecimento recíproco os indivíduos identificados através de um determinado grupo social que existe objetivamente, com sua história, suas tradições, suas normas, seus interesses" (Ciampa, 1995, p.64), sendo que existir objetivamente significa estabelecer 
relações entre os membros e o ambiente em que o grupo está situado, portanto, significa uma ação prática disso, podemos dizer que "(...) nós somos nas nossas ações, nós nos fazemos pela prática" (Ciampa, 1995, p.64).

Para Ciampa (1995) não podemos definir a identidade apenas a partir de aspectos representacionais isolados, é preciso considerar, também, os aspectos biológicos, sociais, psicológicos, pois eles se interpenetram e são constitutivos do indivíduo, o que nos possibilita pensar a identidade como sendo pressuposta e que para se reafirmar deverá ser reposta.

Explicando melhor, há uma identidade que nos é esperada, porém, somente nos reafirmamos a partir do momento que a repomos ou não, ou seja, em que nossas ações práticas (relações) a renova ou a contraria.

De certa forma, reatualizamos através de rituais sociais uma identidade pressuposta que assim é resposta como algo já dado, retirando em consequência o seu caráter de historicidade, aproximando-a mais da noção de um mito que prescreve as condutas corretas, reproduzindo o social (Ciampa, 1995, p.66).

À medida que nos colocamos no mundo, através de nossas relações, é que a identidade irá se configurar: quando nos tornamos um ser-posto. Nesse sentido, escreve Ciampa (1995, p.66):

A posição de mim (o eu ser-posto) me identifica, discriminando-me como dotado de certos atributos que me dão uma identidade considerada formalmente como atemporal. A reposição da identidade deixa de ser vista como uma sucessão temporal passando a ser vista como simples manifestação de um ser idêntico a si mesmo na sua permanência e estabilidade. A mesmice de mim é pressuposta como dada permanentemente e não como reposição de uma identidade que uma vez foi posta.

Sendo assim, a identidade está sendo construída a todo o momento, à medida que a repomos. Mas muito mais, está sendo construída a partir dos vários outros que compõem nosso meio social. Por exemplo, quando alguém é pai, ele não é apenas porque teve um filho, mas porque a sua mesmice (que se dá por um enorme número de pessoas ser pai) é reposta cotidianamente. Porém, sua identidade não se configura apenas como ser pai, porque ele também é filho, ou seja, sua identidade também está formada por um outro, que é negado para se reconhecer na posição de pai. Assim, a identidade é uma totalidade, mas que manifesta uma parte do eu como desdobramento das múltiplas determinações a que este eu está presente, o que nos permite dizer que a identidade é uma totalidade formada pela multiplicidade de representações que se interconectam.

Relacionado a isso, outro aspecto é importante abordar: o movimento social humano. De acordo com Ciampa (1995, p.68) não somos algo, mas estamos sendo a todo o momento. Este "estar sendo" é ao, mesmo tempo, um estar sendo que expressa aquilo que somos: nossa humanidade, mas também uma negação da totalidade dessa humanidade, pois é preciso que neguemos nossa totalidade para que possamos nos reconhecer como uma parte dela.

Isso ocorre porque sempre que nos relacionamos com o "outro" nos representamos, e essa representação assume um sentido tríplice: 1) nos representamos, 2) ao nos representar, desempenhamos papéis (aos quais estamos condicionados, por exemplo, ser filha, que podem ocultar outros elementos constituintes de nossa totalidade) e 3) à medida que nos representamos, repomos a identidade pressuposta.

Representações que não são nossas, mas pertencentes ao mundo. Diante delas, encontramos uma miríade de possibilidades que poderiam ser representacionais e que configuram um repertório de representações que formarão nossa identidade. Sendo incorporada a partir das representações, a identidade, embora assuma características individuais, está carregada de sentidos dados por outrem.

Podemos perceber, então, que nossa identidade é formada pelas inúmeras representações que fazemos de nós mesmos, que repomos daquelas representações que nos são esperadas e pelas representações dos papéis a que estamos determinados. A identidade, portanto, não é estática, mas o seu próprio processo de produção. Ser não É! Ser é Estar Sendo! Enfim,

identidade é movimento. Identidade é metamorfose. E sermos Um e um Outro para que cheguemos a ser Um, numa infindável transformação (Ciampa, 1995, p.74).

Até aqui, sabemos que a alteridade só pode existir num contexto plural, em que as diferenças convivem e são formadoras de uma sociedade. Também sabemos que a identidade se forma a partir do reconhecimento do outro e da relação que se estabelece entre o eu e o "outro", entendido como objeto de conhecimento. Porém, para que comecemos a amarrar as coisas, 
voltaremos a duas questões: quem é o "outro"? Onde se insere o espaço da diferença, requerido pela alteridade, entre o "eu" e o outro?

De imediato, temos condições de responder que o outro não é a nossa negação, mas se nos reconhecemos a partir do confronto com o "outro" e com as representações que temos dele, como preservar o espaço da diferença, não reduzindo-o às nossas representações?

Como vimos, no processo de aquisição do conhecimento, o "outro" ocupa um espaço muito importante, desenvolvendo uma função imprescindível: auxiliar o sujeito na busca pela sua própria identidade, saindo da condição de um objeto no mundo que está sujeito aos saberes apresentados para se reconhecer como um sujeito que produz saberes e atua nesse mundo.

Porém, há muitas formas de se relacionar com esse "outro", com o próprio eu e, por conseguinte, com a própria relação "eu-outro".

Para Guareschi (1999a), num mundo em que o sujeito se coloca como indivíduo único, como o centro dos acontecimentos, tal como está estruturada a ideologia do sistema capitalista, baseada na competição e individualização dos seres e que resulta num narcisismo desenfreado, o "outro" não interessa ou está em segundo plano.

\section{Nesse contexto,}

(...) o outro não significa ou pouco significa para nós. Pois ele não faz parte de nós, é um estranho, um alienígena. Ele é o índio, o negro, a mulher, o excluído. Eu o explico, eu o domino, eu o exploro. E mais: sou eu que decido quando há dominação, quando há compreensão, quando há exploração (Guareschi, 1999a, p.159-160).

Quando esta representação do outro é configurada, legitima-se o surgimento do etnocentrismo, do preconceito, do genocídio e do etnocídio.

Nessa representação, o parâmetro para designar o "outro" é sempre o eu, sendo o "outro" aquele que difere de mim, não por suas qualidades, desejos ou objetivos próprios, mas pelo fato de que não é igual a mim. Assim, a sua diferença é ressaltada, à medida que não corresponde ao meu padrão de igualdade. Portanto, a condição do "outro" não é respeitada, aquilo que lhe faz diferente se apresenta apenas como a negação daquilo que não sou, de modo que a condição do "outro" passa ser a minha diferença: o outro é aquilo que não sou e a alteridade inexiste, pois a diferença é resultado da minha negação.

Tendo essa visão do "outro", jamais poderemos falar em convivência plural, já que para ser plural, é preciso que existam vários outros, cada um com sua especificidade. Além disso, diz Jovchelovitch (1999, p.74),

não basta, portanto, admitir a realidade do outro. É necessário reconhecê-la como a realidade de um sujeito legítimo, que não apenas me constitui enquanto eu, mas que se apresenta como portador dum projeto que lhe é próprio e merece ser reconhecido

No momento que há um reconhecimento mútuo entre os diferentes, emerge a alteridade e cria-se um espaço dialógico entre "os outros".

Para Thomaz (1995), esse reconhecimento do outro só é possível quando o olhar que lançamos a ele não é um olhar que enxerga somente nossas experiências, carregado de preconceitos e pré-noções, mas um olhar relativizador, que o vê a partir de suas especificidades e que torna familiar (no sentido de que não causa estranhamento objetivado) qualquer manifestação da diferença.

É também um olhar relativizador que nos possibilitará reconhecer a nós próprios, já que pressupõe que devemos estranhar o familiar $e$ familiarizar o estranho, não no sentido de que devemos tornar próxima qualquer diferença, mas de que devamos lançar um olhar estrangeiro para o interior de nosso próprio grupo considerado, muitas vezes, "normal" e "homogêneo". O que significa dizer, segundo Jovchelovitch (2000, p.42), "integrar aquilo que é novo, dar sentido ao desconhecido".

Tomando esse olhar que familiariza e acolhe, reconhecendo o outro em sua especificidade, têm-se a pluralidade e, por extensão, a alteridade. Nesse espaço plural, segundo Jovchelovitch (1999), a convivência só será possível se for aberto o canal de comunicação entre os grupos.

O processo de troca, comunhão e construção de novas realidades que se formam a partir do confronto entre diferentes, que pressupõe o ato de conviver, de acordo com seu ponto de vista, está na comunicação. É a comunicação entre os grupos que possibilitará o espaço para a alteridade emergir, pois à medida que entramos em relação com o "outro" somos capazes de reconhecê-lo em sua especificidade como sujeito legítimo. 
Para Guareschi (1999a), a possibilidade de uma convivência plural só é possível quando o homem é entendido como relação, porque é no espaço relacional que as diferenças poderão ser reconhecidas e pensadas. Ou seja, que é pessoa e como pessoa, ele é relação,

isto é, alguém que é um, que constitui uma unidade, mas ao mesmo tempo não pode 'ser' em completude sem os 'outros'; para 'ser', ele necessita intrinsecamente dos outros (Guareschi, 1999, p.153).

O que significa dizer que estabelecer relações, ser relação, não é apenas dialogar ou trocar experiências com os vários outros que compõem nosso ambiente social, mas se comprometer com esses e se permitir ser transformado por eles, num processo de troca mútua.

O entendimento do homem como relação nos auxilia na convivência plural, pois diante do outro, devemos relativizar nosso olhar à sua cultura. Devemos sempre percebê-lo como relação, relativizando os seus comportamentos aos milhares de relações que o formam. Em poucas palavras: devemos ver o outro com o olhar do outro. Quando isso for possível, poderemos pensar em conviver pluralmente. Sem reconhecermos o outro como legítimo, sem percebê-lo como ser que possui uma singularidade, jamais poderemos conviver (comungar) com a pluralidade. Tenderemos a negligenciá-la ou negá-la porque o diferente nunca encontrará meios para emergir. Sem o diferente, não há a divergência, sem a divergência, não há alteridade (condição de ser outro), sem a alteridade não existe identidade.

\section{Referências}

Adorno, T.W.; Horkheimer. M.A. (1995). A indústria cultural: o esclarecimento como mistificação das massas. In Dialética do esclarecimento (pp.113-156). Rio de Janeiro: Zahar.

Arruda, A. (1999). O ambiente natural e seus habitantes no imaginário brasileiro: negociando a diferença. In Representando a alteridade (pp.17-46). Petrópolis: Vozes.

Ciampa, A. Da C. (1995). Identidade. Em S.T.M. Lane (Org.), Psicologia social: o homem em movimento (pp.58-76). Rio de Janeiro: Brasiliense.
Duveen, G. (1999). A construção da alteridade. In A. Arruda (Org.), Representando a alteridade (pp.83-107). Petrópolis: Vozes.

Guareschi, P. (1998). Ética, justiça e direitos humanos. In Comissão Nacional de Direitos Humanos do Conselho Federal de Psicologia (Orgs.), Psicologia, Ética e Direitos Humanos (pp.9-19). Brasília: Conselho Federal de Psicologia.

Guareschi, P. (1999a). Alteridade e relação: uma perspectiva crítica. In A. Arruda (Org.), Representando a alteridade (pp.149-161). Petrópolis: Vozes.

Guareschi, P. (1999b). Sociologia Crítica: alternativas de mudança. 44 ed. Petrópolis: Vozes.

Jodelet, D. (1999). A alteridade como produto e processo psicossocial. In A. Arruda (Org.), Representando a alteridade (pp.47-67). Petrópolis: Vozes.

Joffe, H. (1999). Degradação, desejo e o "outro". In A. Arruda (Org.), Representando a alteridade (pp.109-128). Petrópolis: Vozes.

Jovchelovitch, S. (1999). Re(des)cobrindo o outro: para um entendimento da alteridade na teoria das representações sociais. In A. Arruda (Org.), Representando a alteridade (pp.69-82). Petrópolis: Vozes.

Jovchelovitch, S. (no prelo). Para uma tipologia dos saberes sociais: representações sociais, comunidade e cultura. Porto Alegre: PUCRS Programa de Pós-Graduação em Psicologia.

Lobo, L.F. (2000). Deficiência: prevenção, diagnóstico e estigma. In H. de B.C. Rodrigues; M.B.S. Leitão \& R.D.B. Barros (Orgs.), Grupos e instituições em análise (pp.113-126). $2^{\mathrm{a}}$ ed. Rio de Janeiro: Record: Rosa dos Tempos.

Peixoto, B.N. (1998). O olhar do estrangeiro. In A. Novaes (Org.), O olhar (pp.361-486). São Paulo: Companhia das Letras.

Thomaz, O.R. (1995). A antropologia e o mundo contemporâneo: cultura e diversidade. Em A. da Silva \& L.D.B. Grupioni (Orgs), A temática indígena na escola (pp.425-441). Brasília: MEC/MARI/UNESCO. 
Universidade da terceira idade: reflexões sobre preconceitos e projetos

Daiane Manerich ${ }^{1}$ Juliana Vieira de Araújo Sandri Biaze Manger Knoll

"O que estas velhas estão fazendo aqui?" Esta foi a pergunta de um grupo de estudantes universitários jovens para outro grupo de estudantes universitários com o dobro ou mais de sua idade. Uma pergunta que muitas pessoas, com a representação de que os anos de vida tornam as pessoas inúteis, incapacitadas para novos aprendizados, fazem constantemente.

Simões (1994) explana sobre a representação da palavra velho, indicando que esta é utilizada como antônimo de jovem, podendo significar deterioração, fracasso, inutilidade, fragilidade, obsoleto e não adequado à vida, dando a impressão de que velho vive improdutivamente e está ultrapassado pela nossa sociedade. A velhice, ainda está vinculada a situações como pobreza, asilamento, doença e dependência.

A palavra velho/a passou a ser xingamento e termo propício apenas àqueles sem futuro na vida, ou que não se enquadram no estereótipo esperado de apresentar-se com "espírito jovem". Possuir "espírito jovem" é entendido como sinônimo de ter desejos, vitalidade, saúde, projetos para o futuro, utilidade social, estar atualizado com as novas tecnologias, informações sobre as novidades locais e globais e exigências do mercado atual de relações interpessoais.

Haddad (1986) chama a atenção para a produção da ideologia da velhice, na qual se reproduz as relações capitalistas do mercado através de ideias, valores, princípios, formando um conjunto de representações sobre a velhice que busca doutrinar os corpos, sentimentos, ações dos velhos:

...a questão social da velhice é formulada desconsiderando os fundamentos materiais da sua existência, vista como ameaça que

\footnotetext{
${ }^{1}$ Estagiária do UNIVIDA, acadêmica do Curso de Jornalismo - UNIVALI.

${ }^{2}$ Enfermeira, professora do Curso de Enfermagem da UNIVALI, Mestre em Assistência de Enfermagem.

${ }^{3}$ Médico especialista em geriatria e gerontologia da Prefeitura Municipal de Itajaí, professor da disciplina de geriatria do Curso de Medicina da UNIVALI.
}

paira sobre todos os homens, independentemente do lugar que ocupam no processo produtivo, camuflando o fato de que a classe trabalhadora, formada pelos homens mercadoria, que aciona o processo produtivo, a protagoniza historicamente constituída, da tragédia do fim da vida. (Haddad, 1986, p.46)

Muitas velhices correspondiam - e outras continuam sendo condizentes - com o quadro descrito: as pessoas percebem-se como alguém que já contribuiu com a família, com o mercado e na velhice estão inúteis, doentes e consideradas um peso para a sociedade.

Para Debert (1999) a crítica ao sistema capitalista por abandonar o velho, imputando-o à miséria e exclusão, é um dos elementos do discurso gerontológico do país. A autora explicita outros elementos deste discurso, como a iminência da explosão demográfica; a crítica à cultura brasileira de cultuar o jovem e o novo, tratando os velhos com descaso e a incapacidade do Estado de criar condições de apoio social aos idosos que necessitam. Porém, salienta que esta representação não corresponde aos relatos apresentados pelos idosos quando perguntados sobre como é viver a vida neste "período".

Uma imagem superestimada do sofrimento na velhice, quando difundida por profissionais da gerontologia, traz em si uma implicação ética: a produção da demanda de serviços para diminuir este sofrimento (Debert, 1999).

A mídia, de modo contrário a gerontologia, segundo a mesma autora, tem se encarregado de apresentar a velhice como sinônimo de bem-estar, vitalidade e autonomia e, ainda, como fonte de recursos para um novo e promissor mercado. Esta nova imagem da velhice saudável também tem suas implicações:

Ao louvar pessoas saudáveis e bem sucedidas que aderiram ao estilo de vida e à parafernália de técnicas de manutenção corporal veiculadas pela mídia, assistimos à emergência de novos estereótipos. Os problemas ligados à velhice passam a ser tratados como problema de quem não é ativo e não está envolvido em programas de rejuvenescimento e, por isso, se atinge a velhice no isolamento e na doença, é culpa exclusivamente dele (Debert, 1999, p.229). 
Essas considerações partem do pressuposto, como aponta Sais (1995, p.7), da velhice como um fenômeno "genérico-abstrato ao qual pertencem às pessoas com sessenta anos e mais". Porém, este autor explicita que este conceito não dá conta da complexidade dos velhos/as reais, aqueles que conhecemos, pois a velhice não é homogênea. Logo, é preciso falar dos velhos e não da velhice.

O discurso dominante na nossa sociedade padroniza as pessoas, as velhices, sem respeitar a diversidade e heterogeneidade. A percepção que se tem da velhice é permeada de artefatos culturais, significados, valores e (pré)conceitos o que faz com que as pessoas sintam-se ofendidas ao serem chamadas de velhas, preferindo eufemismos como "terceira idade" (Lima, 2001). Diversas outras denominações são inventadas, buscando fugir do mal-estar causado pelas terminologias pejorativas que acompanham a idade relativa à velhice.

A idade delimita comportamentos e espaços, tornando-se mais do que um indicador do tempo, passando a ser um organizador social (Néri, 2001). Estes comportamentos passam a ser classificados como apropriados ou "normais" para aquele período da vida, gerando estereótipos e preconceitos em relação a idade.

A representação que se tem da velhice como natural ao ciclo biológico de nascimento, crescimento, reprodução e morte escamoteia que a velhice é uma categoria socialmente produzida, como se cada "fase" fosse constituída de propriedades substanciais que a formassem (Debert, 1998). Pesquisadores concordam que a idade é um importante indicador dos processos de desenvolvimento e envelhecimento, mas não a causa destes (Néri, 2001).

A homogeneidade da velhice tem uma função mais epistemológica do que ontológica, ou seja, está mais a serviço do conhecimento do que do fenômeno do ser em si. A velhice se constitui de diferentes formas, dependendo do lugar ocupado no âmbito das relações de gênero, classe, etnia, hierarquia social a que pertencem.

Porém, através do modo generalista de produzir ciência, acaba-se agrupando e classificando as pessoas, sob o discurso de conhecê-las. Para Foucault (1998) o discurso científico que professa um saber contém uma "vontade de verdade" e funciona como sistemas de exclusão e de coerção.
Com o discurso sobre os velhos e velhices, não é diferente. Vários discursos diferentes reclamam para si o abarcamento do fenômeno da velhice, em maior intensidade do que outros.

Há uma implicação ética, política e estética na produção conceitual, regulada por valores, ideologias e representações que orientam um conjunto de estratégias para inclusão ou exclusão dos idosos no campo social (Birman, 1995).

As questões explicitadas nos impuseram um desafio: como criar um programa que pudesse proporcionar um espaço de interações na universidade para pessoas em qualquer idade, especialmente na velhice, que proporcionasse uma análise crítica do que está posto e gerasse novas possibilidades de vida, de escuta para a diversidade e heterogeneidade do envelhecimento humano?

Uma trajetória histórica de conflitos, de embates teóricos e de diálogos com pessoas conhecedoras da área resultou num programa denominado Curso Superior de Extensão Universidade da Vida UNIVIDA, desenvolvido na UNIVALI - Universidade do Vale do Itajaí, que será apresentado e contextualizado. Antes disso, se faz necessário compreender o desenvolvimento das universidades da terceira idade no mundo e no país.

\section{As "universidades da terceira idade"}

Como foi que pessoas com idade avançada conquistaram um espaço na universidade? $\mathrm{O}$ que pessoas aposentadas ou sem interesse em uma carreira profissional estão fazendo na universidade? Compreender o histórico e princípios que embasam as denominadas "universidades da terceira idade" pode trazer algumas luzes para esta questão.

Cachioni (1999) faz um resgate histórico de desenvolvimento destes programas no mundo e no Brasil. Segundo ela, programas educativos para adultos com enfoque na cidadania, buscando a alfabetização, o ensino religioso e a participação na política nos Estados Unidos remonta o século XVIII.

Naquele país, a educação para adultos e idosos na década de 50 foi direcionada à preparação para aposentadoria, retreinamento de funcionários idosos ou atualização cultural desta população. Este processo se dá no 
contexto das Instituições de Ensino Superior, criando uma rede de conhecimentos e serviços direcionados a esta população, fundando a Gerontologia Educacional, na década de 70.

A Universidade de Ciências Sociais de Toulouse, na França, foi a primeira a fundar a "universidade da terceira idade", por Pierre Velas, em 1973. Esta denominação, terceira idade, fazia referência a uma nova etapa de improdutividade no curso de vida, ou seja, aos recém-aposentados. Partiu da constatação de que havia um grande número de pessoas aposentadas e com vitalidade, desejo e disponibilidade para aproveitar sua saúde e recursos materiais para desenvolver atividades novas e desafiadoras que lhe trouxessem interesse pela vida, alegria, bem-estar (Cachioni,1999). Num segundo modelo francês, as atividades centravam-se em preparar os idosos para contribuir com a sociedade. Com o crescimento deste programa, criou-se novo modelo, no qual os alunos passaram a ter um papel mais ativo, desenvolvendo pesquisas sobre envelhecimento e participando regularmente de disciplinas acadêmicas (Peixoto, 1997).

A Associação Internacional de Universidades da Terceira Idade (Auita) foi organizada em 1975 e, em 1981, já agregava mais de 170 instituições (Swindell e Thompson apud Cachioni,1999), é reconhecida pela ONU, OMS, Unesco e reúne profissionais, estudantes e especialistas em Gerontologia. Esta ideia logo se espalhou pelo mundo, com diferentes modalidades, objetivos e atividades.

No Brasil, na década de 60, o SESC (Serviço Social e do Comércio) já trabalhava com educação de adultos e, nos anos 70 implementou a "escola aberta". Apenas em 1980, é que as universidades brasileiras abrem espaço para educação gerontológica e para a chamada "terceira idade". A UFSC (Universidade Federal de Santa Catarina) foi pioneira em 1982 quando foi criado o NETI (Núcleo de Estudos da Terceira Idade), que até hoje oferece Especialização na área da Gerontologia e diversos cursos para pessoas acima de 60 anos. Muitos outros cursos se desenvolveram neste período, com diferentes modelos, objetivos e princípios. Têm sido realizadas pesquisas para avaliar o impacto na população idosa deste retorno à universidade.

"Estou na universidade!" Uma frase que traz muitas emoções, significados, pois pertencer ao meio universitário, em especial quando não se pertence a faixa etária esperada para este ingresso, pode modificar a vida de muitas pessoas.

O impacto de frequentar a universidade na terceira idade, conforme pesquisa realizada por Elbolato (apud Néri e Cachioni, 1999) é positivo, pois traz benefícios pessoais, intelectuais e sociais. Estes estudos revelam que ocorreram

alterações positivas em suas concepções de envelhecimento, nos cuidados com a saúde, na rotina de vida, no enfrentamento de problemas, no relacionamento com os amigos e na autopercepção (Néri e Cachioni, p.33, 1999).

Em outra pesquisa realizada por Cachioni (1998) participantes de uma universidade relataram que os principais ganhos referiram-se a um sentimento de maior valorização social, mais respeito, além de melhora em seu bem-estar subjetivo, indicada por critérios como saúde, satisfação, perspectiva de futuro e relações familiares.

Alunos/as do UNIVIDA confirmam que ocorre uma transformação em suas vidas quando passam a participar deste curso, declaram-se mais saudáveis, há uma melhora no relacionamento familiar, no raciocínio, na memória, na sensação de bem-estar com a própria vida. Mas, como é mesmo este curso? A seguir será explicitados sua estrutura, proposta pedagógica e princípios.

\section{Revelando uma proposta para a "universidade da terceira idade" no} sul do país

O Curso Superior de Extensão Universidade da Vida, ou UNIVIDA, como é carinhosamente chamado pelos professores e alunos que participam deste projeto, tem como objetivos promover um envelhecimento saudável e com qualidade de vida e capacitar para a atuação voluntária; motivar os alunos através da participação ativa na sociedade, seja com trabalho em projetos ou instituições ou ainda com o desejo do aprendizado e da descoberta.

Através da educação continuada promove-se uma representação do envelhecimento como algo construído durante toda a sua existência e que pode trazer ganhos. Busca-se formar multiplicadores sociais que difundam informações sobre o envelhecimento saudável, íntegro e digno. Isso não 
significa negar as condições materiais de existência da miséria, das doenças e das incapacidades, mas demonstrar que várias transformações são possíveis, seja no âmbito privado ou público, individual ou social, no cotidiano ou em espaços qualitativamente diferenciados de decisões coletivas. E assim, através de conhecimento e da informação, afasta-se a imagem do determinismo da velhice como solidão, doença e dependência, minimizando preconceitos sociais.

No UNIVIDA, através de disciplinas na área da saúde, estuda-se realisticamente os processos de envelhecimento, saúde e doença, inclusive ampliando estes conceitos (que não cabe discuti-los neste momento) para uma perspectiva mais crítica. Os participantes do curso podem criar outras imagens sobre a velhice, abarcando as diversidades e heterogeneidades a partir da perspectiva de diferentes profissionais.

Várias disciplinas trazem suporte para isto, como por exemplo, Enfermagem, Fisioterapia, Fonoaudiologia, Nutrição, Odontologia, Psicologia e Gerontogeriatria. Não apenas na área da saúde, mas também há disciplinas das áreas de ciências humanas e sociais como Aspectos Sociopolíticos, Cidadania e Direito, Lazer e Cultura e Turismo na Atualidade, que promovem conhecimento do contexto social e da produção da cultura.

Já a disciplina Preparação para Ação Voluntária é ministrada nos dois últimos semestres e possibilita aos alunos conhecer projetos na área do Terceiro Setor, existentes em Itajaí e cidades vizinhas e incentiva os alunos a criarem seus projetos.

Um destes projetos resultou no Grupo de Estudos e Apoio aos Familiares e Cuidadores dos Portadores da Doença de Alzheimer e Doenças Similares - GEAz, o qual foi criado por seis egressos do UNIVIDA que contam com o apoio técnico dos professores da disciplina de gerontogeriatria, sendo um médico, uma enfermeira e uma psicóloga, especialistas na área.

Este grupo, GEAz, presta uma grande ajuda aos que enfrentam tais doenças na família. É crescente o número de pessoas que procuram o auxílio do grupo. Desde sua criação, em menos de um ano, mais de 34 familiares e cuidadores já se cadastraram no projeto e estão sendo beneficiadas pelo mesmo. Outros projetos como uma central de voluntariado para direcionar os alunos egressos e mesmo os que ainda estão em curso e desejam atuar com a prestação de serviço gratuito estão sendo elaborados.

$\mathrm{O}$ trabalho com disciplinas interligadas facilita o engajamento nos projetos de atuação voluntária e também promove uma visão ampla e crítica, tanto em relação ao processo de envelhecimento quanto das questões sociais. Para tornar viável o trabalho integrado, os professores reúnem-se periodicamente e têm suas disciplinas organizadas visando temas transversais como envelhecimento saudável e atuação voluntária.

O eixo pedagógico escolhido pela equipe de professores foi pautado na teoria de Vygotsky e Paulo Freire, como proposto por Bonin (1999). Ambos são da linha histórico-cultural, se contrapõe ao modelo bancário de educação e reconhecem que o aprendizado ocorre no diálogo, valorizando as pessoas e sua capacidade de aprendizagem, independentemente do grau de escolarização. Estabelecendo a associação da dialógica de Paulo Freire com a dialética de Vygotsky, tem-se a perspectiva de que a pessoa não está passiva diante dos determinantes sociais, mas é autor da história, sua e da humanidade. O sujeito tem a possibilidade, através do processo de conscientização, de transformar a si e ao seu contexto histórico-cultural-social.

Os alunos não são nulos no processo, pelo contrário, estão constantemente participando, contextualizando suas experiências na teoria abordada, proporcionando uma relação de mutualidade e reciprocidade em que ocorre a interação professor e aluno, favorecendo a tomada de consciência crítica de seu cotidiano.

Desta forma, é possível uma troca de experiências, pois se acredita numa relação dialógica, em que professor e aluno aprendem mutuamente, objetivando uma consciência crítica, problematizadora. O processo ensinoaprendizagem é compreendido de modo participativo, ativo, que se dá através de mediações, isto é, interações sociais que permitem que o sujeito seja transformado e transformador de seu meio.

O ensino-aprendizagem é um processo que se concretiza, de um lado, pelas possibilidades do aluno, que englobam tanto a organização do pensamento como os conhecimentos e experiências prévias e, de outro, pela interação com outros agentes. 
A interação que ocorre entre os alunos do UNIVIDA e demais acadêmicos cria um espaço de troca e interações que propicia a quebra de vários preconceitos e estereótipos, promovendo uma relação diferenciada daquela explicitada no início deste capítulo. Em vários seminários, eventos científicos e outras ocasiões em que houve um espaço para compartilhar experiências, nas quais se encontram estudantes da graduação e do UNIVIDA, realizando apresentações artísticas ou culturais, ou expondo seus conhecimentos e aprendizados, foi extremamente profícuo o clima de respeito, revelações e descobertas mútuas.

Uma característica implícita na forma como o curso está organizado é a saída deste aluno da universidade, criada propositadamente. Em alguns modelos de universidade da terceira idade no Brasil, observa-se que existe uma tendência a tornarem-se centros de convivência, pois mantém o idoso na universidade por vários anos. Diferentes cursos são criados e os interessados passam de um curso para outro. É comum os alunos solicitarem a criação de novos projetos na universidade para permanecerem ocupando este espaço. Pautada na concepção de que é importante que a instituição de ensino superior não se constitua como um mercado de serviços, mas como um espaço que promove subsídios para a independência, autonomia e criação de espaços compartilhados por pessoas em todas as idades é que se criou um programa que tivesse um período determinado.

A descrição da estrutura e dos modos de relação geradas no UNIVIDA teve como objetivos revelar o compromisso ético, que se estabelece na práxis cotidiana do fazer e (re)criar-se em uma relação dialógica que vai além do individualismo ou do mero cientificismo neutro e transcende para a criatividade, a reflexão crítica e a solidariedade.

\section{Ética e paradigmas: considerações finais}

O tratamento dado aos velhos pelos jovens, crianças e pelas próprias pessoas envelhecidas em suas relações cotidianas são permeadas por estes valores, por ideologias, por uma ética.

Compreendendo a ética como uma "dimensão implícita de todos os nossos atos" (Guareschi, 1998, p.160) e que a não discussão das injustiças e desigualdades da nossa sociedade promove o continuísmo destas práticas, é que nos propomos a discutir sobre as imagens da velhice e suas implicações.
O pressuposto de que não há dicotomia indivíduo $x$ grupo, não há separação entre o social e o individual (Lane e Codo, 1984) nos remete à responsabilidade de questionar constantemente nossa práxis, pois é no enlace de nossas ações que nos construímos enquanto sociedade. Neste sentido, o UNIVIDA é uma experiência coletiva, que se constrói nas interrelações, através das várias interfaces entre professores, alunos, famílias, instituições, representações. Em nome desta coletividade, é necessário explicitar que a autoria deste artigo tem os nomes de quem escreveu estas linhas, mas a construção não foi singular. Os recursos linguísticos para explicitar as interligações são ínfimos e ao buscar fazê-lo, volta-se ao padrão anterior de separações e linearizações.

$\mathrm{O}$ princípio da interdisciplinaridade se faz neste projeto muito mais como uma integração de diferenças, na busca de ações conjuntas, mesmo que no seu interior sejam reveladas mais divergências do que uniformidades.

A explicitação de um modelo de autonomia, independência, bemestar, satisfação com a vida e exercício de cidadania de algumas pessoas com mais idade pode fortalecer a uniformização da velhice e falseamento das diferenças, através do não discurso destas diferenças, como refere Gatto (1996). Esta não foi a intenção, mesmo que esta contradição esteja presente.

O objetivo foi compartilhar a experiência na educação gerontológica para vislumbrar a ética e os paradigmas subjacentes em um modelo de "universidade da terceira idade", o desenvolvimento possível de um espaço na universidade para a reflexão sobre o envelhecimento.

É preciso o acordar para a percepção de que a ideia sobre a idade ser geradora de comportamentos, sentimentos e pensamentos, é só uma ideia. Não precisa ser deste modo. A breve reflexão sobre o fenômeno da velhice e sua infinitude de possibilidades de modos de ser através dos velhos e velhas demonstra que a superação do que está posto é possível e cabe a todos nós, produto e produtores de subjetividades, transformar esta realidade.

A produção da subjetividade, como compreende Guattari (1999) se dá nas relações sociais, através de tudo o que é produzido e nos chega pela linguagem, pelo contexto, numa transmissão de significados que definem a maneira de ver o mundo. Afirma que estas mutações não se dão apenas no registro das ideologias, mas que "no próprio coração dos indivíduos" (ibidem, p.26). Nas infinidades de relações que são estabelecidas a partir do 
UNIVIDA é provável estarmos deixando marcas nos corações e fomentando discursos, desejos e criações em busca de solidariedade e ética.

Retirar os velhos do anonimato e a velhice do não viver, ou da vida em intensidade mínima é só o que é possível fazer, sem prescrições de como é esta vida, porque vivemos em coletividade, mas experenciamos este viver em individualidade, mesmo que estas duas dimensões sejam separadas apenas na linguística e na percepção individualista de si na cultura ocidental e não no fato.

\section{Referências}

Birman, J. (1995) Futuro de todos nós: temporalidade, memória e terceira idade na psicanálise. In Veras, R. (org.) Terceira Idade: um envelhecimento digno para cidadão do futuro. (pp.29-49) Rio de Janeiro; Relume-Dumará, UnATI/UERJ.

Bonin, L. F. R. (1999) Educação, Consciência e Cidadania. In Silveira, A; Grewehr, C.; Bonin, L. F. Bulgacov, Y. (orgs.) Cidadania $e$ Participação Social. (pp.107-118) Porto Alegre: ABRAPSOSUL.

Cachioni, M. (1998) Envelhecimento bem sucedido e participação numa universidade para terceira idade: A experiência da universidade de São Francisco. Dissertação de Mestrado. Campinas: Unicamp, Faculdade de Educação.

Cachioni, M. (1999) Universidades da terceira idade: das origens à experiência brasileira. In: Néri, A L., Debert, A G. (org.) Velhice e Sociedade. (pp.141-178) Campinas, SP: Papirus.

Debert G. G. (1999) A Reinvenção da velhice: socialização e processos de reprivatização do envelhecimento. São Paulo: Edusp.

(1998) A antropologia e o estudo dos grupos e das categorias de idade. In M. M. L. de Barros (org.), Velhice ou terceira idade? Estudos antropológicos sobre identidade, memória e política (pp.4968). Rio de Janeiro: Editora Fundação Getúlio Vargas.

Foucault, M. (1998) A ordem do discurso. (4 ${ }^{\mathrm{a}}$ ed.) Coleção Leituras filosóficas. São Paulo: Loyola.
Gatto, L. C. (1996) Psicossexualidade na Terceira Idade. In: Netto, J.P. Gerontologia. (pp.136-145) São Paulo: Atheneu

Guareschi, P. (1998) Alteridade e relação: uma perspectiva crítica. In Arruda, A (org.). Representando a alteridade. Petrópolis, RJ: Vozes.

Guattari, F. e Rolnik, S. (1999) Micropolítica: Cartografias do desejo. (5 ${ }^{\mathbf{a}}$ ed.) Petrópolis, RJ. Vozes

Haddad, E (1986) Ideologia da velhice. São Paulo: Cortez.

Lane, S. e Cada, W. (orgs) (1994) Psicologia Social: o homem em movimento. São Paulo: Brasiliense.

Lima, M.A (2001) A gestão da experiência de envelhecer em um programa para terceira idade: a UnATI/UERJ. IN: Veras, R. (org.) Velhice numa perspectiva de futuro saudável. Rio de janeiro; RelumeDumará, UnATI: UERJ.

Neri, A. L. e Cachioni, M (1999) Velhice bem sucedida e educação. In Néri, A. L. , Debert, A. G. (org.) Velhice e Sociedade. Campinas, SP Papirus.

Neri, A. L. (2001) Desenvolvimento e Envelhecimento: perspectivas biológicas, psicológicas e sociológicas. Campinas, SP: Papirus.

Peixoto, C. (1997) De volta as aulas ou como ser estudante aos 60 anos. In Veras, RP. (org.) Terceira Idade: desafios para o terceiro milênio. Rio de Janeiro: Relume-Dumará, UnATI: UERJ.

Sais, A. (1995) Coisas de velho: coisas de vida. Dissertação de Mestrado. São Paulo: PUCRS.

Simões, R (1994) Corporeidade e terceira idade. Piracicaba: UNIMEP 


\section{Representação social do bom aluno: implicações éticas na educação}

Maria Helena Cordeiro ${ }^{1}$ Anelize Donaduzzi $i^{2}$

Sabrina Maria Schlindwein ${ }^{3}$

O contexto educacional é constituído por sujeitos, sujeitos esses que se encontram e foram construídos a partir de uma dada realidade social. Partindo deste pressuposto, pode-se pensar que os fenômenos educacionais, entre eles: a relação professor/aluno, a seleção de conteúdos, a metodologia adotada, a forma de avaliação utilizada, o fracasso escolar e outros, não têm sua origem unicamente na sala de aula nem em processos cognitivos individuais. Ao contrário, eles extrapolam a sala de aula e os muros da escola. Dessa forma, podemos afirmar que a construção de tais fenômenos está fundamentada nas representações sociais dos professores e, como tal, é produto de múltiplos determinantes históricos, educacionais e socioculturais que direcionam a ação pedagógica cotidiana do docente.

As representações sociais são modos de compreender e explicar a realidade. Não são simples opiniões, imagens ou atitudes sobre o mundo social ou sobre determinado fenômeno, mas "teorias" ou "campos de conhecimento", que constituem em sistemas de ideias, valores e práticas socialmente compartilhadas, que nos permitem

classificar pessoas e objetos, comparar e explicar comportamentos e objetivá-los como parte de nosso ambiente social (Gama, 1991, p.358).

$\mathrm{Na}$ área da educação, pode-se usar o mesmo conceito: são modos de compreender e explicar a realidade educacional, que se constituem em guias da ação pedagógica. É por isso que afirmamos que as opções metodológicas, a prática em sala de aula e a interação do professor com os alunos, são permeadas pelas representações sociais de educação, num

${ }^{1} \mathrm{PhD}$ em Psicologia do Desenvolvimento Cognitivo; Professora da UNIVALI.

${ }^{2}$ Mestranda em Educação, professora do curso de Fonoaudiologia da UNIVALI.

3 Aluna do curso de Psicologia, bolsista do Programa Integrado de Pós-Graduação e Graduação (PIPG) da UNIVALI. sentido mais amplo e de fenômenos educacionais específicos, que são compartilhadas pelo grupo social ao qual o professor pertence.

(...) Podemos entender as representações sociais como ideias, imagens, concepções e visões de mundo que os atores sociais constroem sobre a realidade, as quais estão vinculadas às práticas sociais. Ou seja, cada grupo social elabora representações de acordo com a sua posição no conjunto da sociedade, representações essas que emergem de seus interesses específicos e da própria dinâmica da vida cotidiana (Moreira e Oliveira, 2000, p.XI-XII).

Então, as representações dos professores têm relação direta com a sua profissão, com seus interesses e aspirações, com sua formação e com o seu cotidiano.

Assim, podemos entender a representação social como o processo de assimilação da realidade pelo indivíduo, fruto da integração de seus valores, das suas experiências, das informações que circulam no seu meio sobre um objeto social, bem como das relações que ele estabelece com os outros homens do seu meio. São as afirmações que os indivíduos fazem sobre a realidade e sobre a interação com os outros. É como apreendemos a vida cotidiana. Nesse sentido, é interessante lembrar que uma representação social é sempre de alguém (o sujeito) e de alguma coisa (o objeto). Não se pode falar em representação de alguma coisa desvinculada de uma população ou de um grupo social em específico, que mantenha tal representação.

... Pensa-se essa afinidade em termos de consenso: se um grupo mantém tal representação, isto quer dizer que há um consenso entre os seus membros (Sá, 1998, p.75).

Alves-Mazzotti (2000) fez um levantamento das pesquisas que têm utilizado a teoria das representações sociais e constatou que elas têm se centrado no estudo do cotidiano escolar e, em particular, das práticas docentes. A autora elencou os principais achados relacionados à representação social dos professores. Entre estes, destacam-se:

1. O baixo nível socioeconômico do aluno tende a fazer com que o professor desenvolva baixas expectativas sobre ele;

2. Os professores tendem a interagir diferentemente com alunos sobre os quais formaram altas e baixas expectativas; 
3. Os professores tendem a atribuir o fracasso escolar a condições sociopsicológicas do aluno e a condições econômicas de sua família, eximindo-se de responsabilidade sobre esse fracasso.

Assim, as representações do professor no campo da educação são construções simbólicas que levam as marcas do tempo, do espaço e das relações que definem e articulam as diferentes partes da totalidade social na qual o educador se integra. Tais representações articulam as ideias que circulam na sociedade e no grupo em que vivem e são reconstruídas a partir de suas vivências, de sua história e de suas relações sociais. Neste conjunto, estariam a formação recebida e a própria experiência concreta do trabalho. A construção dessas ideias envolve também a transformação de um conhecimento teórico e científico em senso comum. Gama (1991) explica que tais conhecimentos são socialmente reelaborados e transformados em um novo modo de compreender e explicar a realidade social. Talvez por isso, muitos professores têm dificuldade em identificar incoerências entre sua prática e muitos dos conhecimentos teóricos que dizem defender.

Portanto, as representações comuns aos professores, no que diz respeito à educação e aos seus alunos, não poderiam ser analisadas isoladamente, pois existe uma dinâmica entre os objetos (social, cultural, econômico, histórico, educacional e afetivo) que compõe as representações. Nestas representações, estão sua vida, suas relações e experiências, como também a cultura e a história em que se inserem e dos grupos com os quais interagem. As representações comuns parecem, assim, determinar a natureza dos comportamentos e das informações dos professores.

A representação de "bom aluno", por exemplo, se insere na representação mais abrangente da sociedade desejada (o mundo utópico). Esta representação, a princípio, pode estar relacionada ao filho que cada um gostaria de ter, às outras pessoas da mesma faixa etária, que conhecimento prévio se espera para determinada série, etc. Quando a representação de "bom aluno" deixa de ser específica, tornando-se um novo conceito, passa a ter uma funcionalidade que a "naturaliza", passando a ser utilizada como se sempre tivesse existido ou como se não fosse possível ser professor sem utilizá-la. A noção de "bom aluno" fica como algo inerente à própria espécie humana e seu oposto, ou melhor, os "não-bons alunos", exceções indesejáveis ou desvios a serem corrigidos (Alevato, 1999).
Moreira e Oliveira (2000) iniciam a apresentação do livro "Estudos Interdisciplinares de Representação Social", do qual são organizadores, com a seguinte afirmação

(...) o termo representação social vem sendo bastante útil ao processo de compreensão de diferentes objetos, especialmente naquelas áreas do conhecimento onde a subjetividade é inegavelmente partícipe das práticas cotidianas

Sem sombra de dúvida, a representação do professor sobre o "bom" ou o "mau" aluno tem relação direta com a sua subjetividade e, consequentemente, com as expectativas que esse professor deposita no seu aluno real. Tais representações fazem com que o professor pense, aja, fale e se relacione com os alunos guiado por uma representação ampla do que é ser um aluno.

O estudo de Rangel (1997, p.13) também embasado na teoria da representação social, focaliza os

elementos das dimensões da representação do "bom aluno", discutindo-os com atenção ao aluno "real" ou "ideal", conforme os sujeitos os percebem e expressam nas suas afirmações e revêem no seu relato de vida como alunos.

Este estudo aponta para as seguintes constatações:

1. Os conceitos que os professores formam a respeito dos alunos são influenciados pelo tipo de relação estabelecida entre eles;

2. O "mérito" pelo sucesso ou fracasso escolar recai sobre habilidades pessoais, omitindo-se as causas sociais mais amplas e o compromisso (pedagógico e social) da escola com essas causas;

3. Existe, para os professores, uma estreita relação entre sucesso na escola e sucesso na vida e no trabalho.

Pode-se então constatar que o julgamento do valor de ser "bom aluno" incorpora o julgamento do valor do estudo, da escola, como fatores de realização - profissional e social — "absolutizados" em seu "poder". Articula-se a este julgamento o valor "pessoal", "individual" de quem estuda e se torna o (único) responsável pelas suas "conquistas" e seu "sucesso" (Rangel, 1997, p.52). Para a autora, existe uma consolidação e naturalização das representações entre os professores, sendo que este fato 
também se aplica à imagem idealizada do "bom aluno", tão difícil de ser mudada, pois, "a representação não é só uma resposta, mas também um estímulo ao comportamento" (Idem, p.75).

Desta forma, as representações dos professores fazem com que eles adotem

um modelo ideal de aluno que não corresponde ao aluno concreto que hoje constitui a maior parte da clientela da escola pública do ensino fundamental: a criança pobre, cujos pais têm baixa ou nenhuma escolaridade e lutam pela sobrevivência (Alves-Mazzotti, 2000, p.58).

As pesquisas de Gama (1991) demonstram que tanto o aluno da escola pública quanto a sua família são representados distorcidamente pelo professor. Estas pesquisas

(...) revelam representações sociais cujo conteúdo apresenta um misto de determinismo sociológico, associado a uma pseudopsicologia da criança pobre, que a classifica como culturalmente deficiente bem como cognitiva e intelectualmente inadequada para aprender (Gama, 1991, p.378).

Essa contradição existente entre o aluno ideal e o aluno real traz suas marcas na prática pedagógica. Alguns estudos têm mostrado que as expectativas dos professores (baseadas nas representações destes) são determinantes para o sucesso ou fracasso dos seus alunos.

Portanto, é provável que as representações dos professores sobre a capacidade dos alunos afetem suas práticas de ensino, sua forma de interagir com cada criança, o que explicaria a interferência no desempenho escolar dos mesmos. De acordo com Alves-Mazzotti (2000, p.61)

(...) os elementos da representação não apenas exprimem relações sociais, mas contribuem para constituí-las.

Essa questão foi investigada em uma pesquisa exploratória (Cordeiro, Donaduzzi e Schlindwein, 2002) realizada com professoras (oito de Itajaí e dez de Blumenau) de turmas de pré-escolar, usando-se o Procedimento de Classificações Múltiplas (Roazzi, 1995) na coleta de dados. Na análise dos dados foi utilizado o programa MDS-Multidimensional Scale, o qual produziu uma configuração dos conceitos das professoras, baseada nas semelhanças entre as categorizações dos atributos por elas utilizados (vide figura $1 \mathrm{e} 2$ ).

Figura 1 - Configuração da distância Euclidiana dos atributos relacionados a bom e a mau aluno no município de Itajaí.

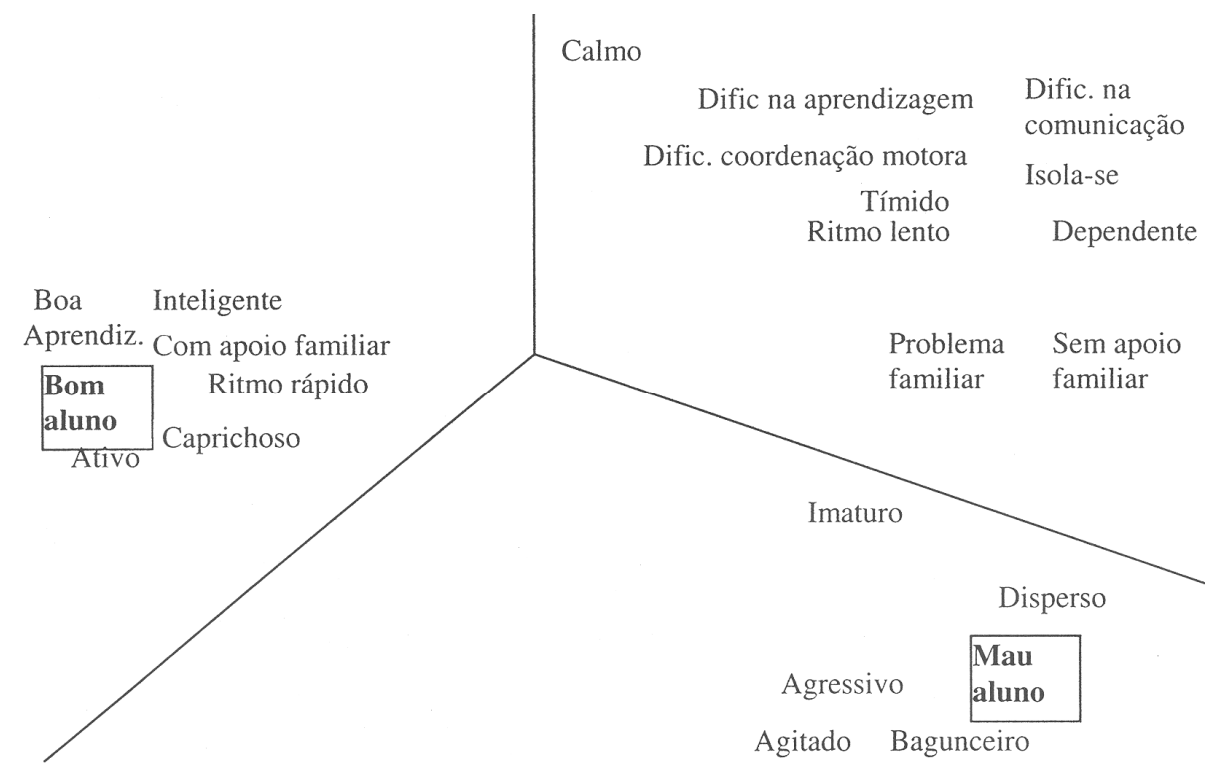


Figura 2 - Configuração da distância Euclidiana dos atributos relacionados a bom e a mau aluno no município de Blumenau.

$$
\begin{aligned}
& \begin{array}{l}
\text { Dific. } \\
\text { comunicação Tímido }
\end{array} \\
& \text { Isola-se } \\
& \text { Ritmo lento } \\
& \text { Dependente } \\
& \text { Dific coordenação } \\
& \text { motora Disperso } \\
& \text { Problema familiar } \\
& \text { Sem apoio familiar } \\
& \text { Dificuldade na Imaturo } \\
& \text { aprendizagem } \\
& \begin{array}{|l|}
\hline \text { Mau aluno } \\
\text { Agitado Agressivo Bagunceiro }
\end{array} \\
& \text { Com apoio } \\
& \text { familiar } \\
& \text { Calmo } \\
& \text { Bom } \\
& \text { Caprichoso } \\
& \text { Ativo } \begin{array}{r}
\text { Boa } \\
\text { aprendizagem }
\end{array} \\
& \text { Inteligente }
\end{aligned}
$$

Quanto maior as semelhanças dessas categorizações, mais próximos se localizaram os atributos em um diagrama espacial. Foi constatado que, em ambos os municípios, a representação do bom aluno está intimamente associada ao conceito de boa aprendizagem, com todos os atributos que a caracterizam: caprichoso, inteligente, ativo, com ritmo rápido e apoiado pela família. Em oposição à representação de bom aluno, foi encontrado um grupo de atributos que caracterizam as dificuldades de aprendizagem: disperso, dependente, com dificuldade de comunicação, com dificuldade de coordenação motora, isolando-se, tímido, com ritmo lento, sem apoio familiar, com problemas familiares. Estes atributos têm em comum o fato de sua superação não depender da própria criança, sozinha. Entre as professoras de Itajaí, as dificuldades de aprendizagem apareceram mais relacionadas às dificuldades de comunicação e de coordenação motora. E interessante notar que, para estas professoras, o rótulo "mau aluno" não apareceu tão associado às dificuldades de aprendizagem e sim a aspectos comportamentais, que, de uma forma ou de outra, parecem ser considerados mais transitórios e, ao mesmo tempo, mais dependentes da boa vontade do aluno: agressivo, agitado, bagunceiro.

Entretanto, em Blumenau, o rótulo "mau aluno" aproximou-se mais do grupo de atributos associados a dificuldades de aprendizagem, sobretudo os que se referiam à falta de apoio familiar e problemas familiares, tendendo a integrar em um único núcleo esses atributos e os aspectos comportamentais negativos. Estas diferenças parecem indicar que a representação de bom aluno se organiza de forma semelhante nos dois municípios, enquanto que a organização dos atributos que se opõem a essa representação depende de fatores contextuais. Com efeito, em Blumenau o pré-escolar é considerado como o primeiro ano do primeiro ciclo do ensino fundamental, o que implica em expectativas de aprendizagem escolar; já em Itajaí, o pré-escolar é considerado o último ano da Educação Infantil, o que, provavelmente reduz a ansiedade das professoras em relação ao desempenho dos alunos em atividades "escolares".

Portanto, quanto mais se espera da criança que cumpra as expectativas de escolarização, maior peso vão tendo os aspectos ligados à aprendizagem nas classificações que as professoras fazem desses alunos. Mesmo assim, os atributos que se afastam da representação do "bom aluno" não se agrupam claramente para constituírem a representação do que poderia ser o seu oposto, isto é o "mau-aluno". Portanto, a representação de "bom aluno" parece ser uma representação bastante consolidada, uma cristalização do aluno ideal que existe independentemente do contexto social e da organização escolar. Essa representação se fortalece quando o aluno ideal é personificado em alunos específicos, reais: se uns se encaixam na categoria "bom aluno", mesmo nas condições mais adversas, então o "bom aluno" é real, ou seja, por meio de um processo de objetivação (Moscovici, 1978), a funcionalidade da representação é confirmada, tornando-a mais sólida, mais consensual. Entretanto, se uns "se encaixam", por que outros não se encaixam? A dificuldade de ancorar (idem), ou seja, de classificar os "não-bons alunos" em uma categoria (várias professoras descartaram a expressão "mau aluno" no procedimento de classificações múltiplas) sugere que, no confronto com os alunos reais, surgem contradições que denunciam as relações de dominação que vêm se perpetuando no cotidiano escolar e que são mascaradas pelo discurso acadêmico "politicamente correto" da inclusão. Com efeito, a "fluidez" da 
representação de "mau aluno" em oposição à solidez da representação de bom aluno revela um certo pudor em rotular as crianças, o que pode revelar a influência das discussões acadêmicas sobre inclusão na formação das representações. Esse pudor foi expresso claramente por uma das professoras: "Como é que eu vou chamar eles de burrinhos? De inteligentes, sim". Desta forma, as discussões éticas que colocam a necessidade de não rotulação das crianças e o respeito pelas diferenças individuais são assimiladas parcialmente em termos de discurso, mas não afetam a representação que as professoras fazem dos seus alunos, provavelmente porque estas não estão isoladas das imagens e dos valores atribuídos socialmente ao estudo, à escola e à realização profissional. Assim, na representação do bom aluno, continua não havendo espaço para os "diferentes". Considerando-se que é a partir desta representação que as professoras constroem suas expectativas sobre o futuro escolar e profissional de seus alunos, torna-se imperativo compreender a dinâmica dessas representações e sua relação com as práticas escolares, para que se vislumbre um caminho que leve à mudança das mesmas.

Cabe aqui uma questão: As representações sociais de um determinado grupo (no caso, os professores) podem ser mudadas? De acordo com Rangel (1999), as mudanças podem acontecer por alterações progressivas de percepções e ideias. As mudanças nas representações sociais estão associadas a alterações sociais profundas ou, mais particularmente, nas alterações das dinâmicas de funcionamento dos grupos. Segundo esta autora, "uma das possibilidades de mudança está no dinamismo da formação e da influência nas ações do processo de representação social" (idem, p.59). Portanto, a mudança das representações torna-se possível pelo confronto dos vários significados, muitas vezes contraditórios, que coexistem nessas representações e, ao mesmo tempo, pela tomada de consciência da relação entre essas representações e as práticas que se reproduzem nos grupos sociais.

A educação é construída nas relações concretas da totalidade social. Traz suas marcas e contradições. Não é um ato isolado, nem decorre da boa vontade de indivíduos ou da idealização de dirigentes. Entre o discurso destes e a prática quotidiana está a distância entre os efetivos interesses em jogo, interesses que extrapolam a educação e que têm suas raízes nas relações sociais mais amplas, determinando-a. (Madeira, 1991, p.141).
Nem a educação nem o professor podem ser considerados, quer isoladamente quer em conjunto, como um todo acabado e estático. A dicotomia e a rigidez devem ser superadas, para que se possa chegar à compreensão dos movimentos que vão se constituindo mutuamente. A teoria das representações sociais nos ajuda a compreender porque as pessoas fazem o que fazem, mas mais do que isso, ela pode contribuir para apontar os caminhos da mudança desses "fazeres" - e é imperativo que o faça. Esse é um dos aspectos da dimensão ética da produção do conhecimento em Psicologia Social: "Na verdade, de que ajuda aos grupos humanos dizer, simplesmente, que 'as coisas são assim', sem que se apresentem elementos de transformação e superação de tais situações?" (Guareschi, 1998, p.54).

\section{Referências}

Alevato, H. M. R. (1999). Qualidade: um mito pós-moderno. In: Teves, N. e Rangel, M. (Orgs) Representação Social e Educação. Campinas, SP: Papirus.

Alves-Mazzotti, (2000). Representações Sociais: Desenvolvimentos atuais e aplicações à educação. In: CANDAU, V. M. (Org.) Linguagens, Espaços e Tempos no Ensinar e Aprender. Rio de Janeiro: DP\&A.

Cordeiro, M. H.; Donaduzzi, A. e Schlindwein, S. M. A Representação do "Bom" e do "Mau" Aluno: Um estudo comparativo entre as professoras de pré-escolar nos municípios de Itajaí e Blumenau. In: Máximo, C. E. (coord.) Anais do IX Encontro Regional Sul da ABRAPSO: psicologia social: ética e paradigmas. Itajaí, Se: UNIVALI, 2002.

Gama, E. M. P. (1991). As Percepções sobre a Causalidade do Fracasso Escolar no Discurso Descontente do Magistério. In: Revista Brasileira de Estudos Pedagógicos, v.72, n. 172, (pp.356-384) Brasília, D. F.

Guareschi, P. (1998). Ética. In Maria da Graça Corrêa Jaques et al. Psicologia Social Contemporânea: livro texto. Petrópolis: Editora Vozes. 
Madeira, M. C. (1991). Representações Sociais: pressupostos e implicações. In: Revista Brasileira de Estudos Pedagógicos (Vol.72, n. 171, pp.129-144), Brasília, D. F.

Moreira, A.S.P. e Oliveira, D.C. (Orgs). (2000). Estudos Interdisciplinares de Representação Social. $2^{\mathrm{a}}$ ed. Goiânia: AB.

Moscovici, S. (1978). A representação social da Psicanálise. Tradução da $2^{\mathrm{a}}$ edição francesa da obra La psychanalyse - son image et son publico Rio de Janeiro: Zahar Editores. (Original publicado em 1961).

Rangel, M. (1997). “Bom Aluno” Real ou Ideal? Petrópolis, RJ: Vozes.

. (1999). Das dimensões da representação do "bom professor" às dimensões do processo de ensino-aprendizagem. In: Teves, N. e Rangel, M. (orgs) Representação Social e Educação. Campinas, SP: Papirus.

Roazzi, A. (1995). Categorização, formação de conceitos e processos de construção de mundo: procedimento de classificações múltiplas para o estudo de sistemas conceituais e sua forma de análise através de métodos multidimensionais. Cadernos de Psicologia, 1, 1-27.

Sá, C.P. (1998). A Construção do Objeto de Pesquisa em Representações Sociais. Rio de Janeiro: UERJ.

\section{Discurso e significação dos professores do curso pedagogia sobre o Exame Nacional de Curso}

Luciane Maria Schlindwein ${ }^{1}$ Cláudia Renate Ferreira ${ }^{2}$ Claudia Maria Petri ${ }^{3}$

Este trabalho é parte integrante de um projeto no qual vem-se investigando um programa de avaliação externa, qual seja, o Exame Nacional de Cursos. Este trabalho foi desenvolvido em um curso de Pedagogia, no município de Brusque, Santa Catarina. Trata-se de um curso pequeno com 332 alunos, em oito períodos letivos, em funcionamento desde 1987. Este curso possui um corpo docente qualificado. Em 2001 eram trinta professores: onze especialistas (dos quais, cinco mestrandos); dezessete mestres (dos quais quatro doutorandos) e dois doutores. Justamente por se constituir em um grupo pequeno, os professores procuram trabalhar de forma integrada e, desde 1998 vem sendo discutido, elaborado e implementado o projeto pedagógico do curso.

Foram realizadas entrevistas semi-estruturadas com os 20 professores do curso. Ou seja, todos os professores do curso participaram da pesquisa. O conteúdo das entrevistas foi o exame nacional de cursos e suas implicações no currículo do curso.

Optou-se por uma análise qualitativa, que pudesse captar os significados e sentidos atribuídos pelos professores em seus depoimentos. Na pesquisa qualitativa, o foco das análises volta-se para a compreensão do fenômeno estudado, apreendendo os diferentes detalhes que compõem o campo de pesquisa. A ênfase do trabalho esteve focada na descrição, interpretação e caracterização do discurso dos professores do curso de pedagogia. Esta descrição e caracterização centram-se na percepção destes professores sobre o impacto do ENC no currículo do curso de Pedagogia. De acordo com Bogdan \& Biklen (1994) os investigadores qualitativos

\footnotetext{
${ }^{1}$ Doutora em Psicologia da Educação - PUCSP, docente e pesquisadora da Universidade do vale do Itajaí-UNIVALI.

${ }^{2}$ Mestre em Educação-UNIVALI, docente da Universidade Regional de Blumenau.

${ }^{3}$ Bolsista PIPG-UNIVALI.
} 
buscam compreender o processo no qual as pessoas constroem e transformam significados.

Para empreendermos a análise dos dados, apoiamo-nos nos ditames de Pino (2001, 2002), especialmente no que se refere ao delineamento da metodologia semiótica traçada pelo autor. Nesta perspectiva metodológica, o foco da análise é a palavra, ou melhor, o significado, sentido e valor da palavra no contexto de significação do discurso. Esta empreitada exigiu a articulação dos postulados de Vygotsky (1989), Peirce (19...) e Bakhtin (1979). Este último, com suas contribuições a respeito do dialogismo e polifonismo.

A definição deste marco epistemológico permitiu delinear o valor que uma informação adquire no conjunto de informações em desenvolvimento na investigação. A ênfase das análises recaiu na captação de significados e sentidos dos professores sobre, as vantagens e desvantagens do exame nacional de cursos.

Os sujeitos pesquisados, no caso os professores do curso de pedagogia são os principais protagonistas de investigação. Eles são os enunciatários do discurso e nós, pesquisadores, os destinatários.

A palavra orienta-se para um destinatário e esse destinatário existe numa relação social clara com o sujeito falante. Nosso interlocutor pertence a uma geração, um gênero e uma classe específicos, é alguém com mais ou menos poder do que nós mesmos, alguém próximo ou afastado a nós (Stam, 1992, p.33).

O fenômeno estudado suscitou o esclarecimento de situações vivenciadas no impacto da reestruturação do currículo do curso de Pedagogia, a partir do ENC. Como já foi afirmado anteriormente, este trabalho constituise em um recorte de um trabalho maior cujo objetivo é investigar o impacto da avaliação externa sobre o currículo do curso de pedagogia. Para este objeto maior, foram consultados os registros da Fundação Educacional de Brusque, especialmente do histórico do curso de pedagogia. Foi empreendida uma análise documental do projeto pedagógico do curso. E foram aplicados questionários junto aos alunos e entrevistas, junto aos professores. E importante destacar estes fatos, uma vez que, para além das entrevistas, estes outros dados possibilitaram uma compreensão mais ampla do movimento do curso, em suas condições de oferta, demanda docente e discente.
As entrevistas foram transcritas respeitando-se a literalidade do discurso apresentado pelos sujeitos, bem como a preservação do sentido de suas falas no contexto do discurso. Após a leitura exaustiva das entrevistas já transcritas, foram construídas as categorias de análise.

A esta categorização sucedeu-se uma análise interpretativa. A interpretação supõe um movimento, por parte do pesquisador, no sentido de tomar uma posição acerca das ideias enunciadas. Exige a habilidade de ler nas entrelinhas, a exploração da fecundidade do texto. Esta leitura analítica constitui-se numa tarefa difícil e dedicada. Esta análise esteve pautada nos ditames teóricos de Bakhtin, especialmente no que se refere a análise dos discursos dos professores.

Ao tratar dos fenômenos linguísticos, este autor parte de uma perspectiva histórica, cultural e ideológica na qual se entrelaçam os campos da filosofia, estética, literatura, psicologia, semiótica.

Trata-se de uma teoria que vê o mundo a partir de ruídos, vozes, sentidos, sons e linguagens que se misturam, (re)constrói-se e transformase, adentro disto, esta a palavra que assume papel primordial, pois é a partir dela que o sujeito se constituí e é constituído e traz marcas culturais, sociais e históricas

Bakhtin trata de romper com a concepção de homem que adquire uma linguagem ideal, pronta e acabada e com a dicotomia que toma a linguagem como forma e conteúdo. Diferentemente desta posição, o autor concebe o homem enquanto um ser que dialoga com a realidade por meio da linguagem.

O homem estabelece sua relação com o mundo pelos discursos que ele assimila, formando assim seu repertório de vida. A formação do eu se dá através de uma tríade, o eu-para-mim (como me percebo), o eu-para-osoutros (como apareço aos olhos dos outros) e o outro-para-mim (como percebo o outro), portanto e EU nunca é individual, mas sim social. A consciência individual é, portanto, um fato social e ideológico, a realidade da consciência é a linguagem.

A consciência adquire forma e existência nos signos criados por um grupo organizado no curso de suas relações sociais. Os signos são o alimento da consciência individual, a matéria de seu desenvolvimento, e ela reflete sua lógica e suas leis (Bakhtin, 1999, p.35) 
Bakhtin contesta a concepção de Saussure a respeito da língua como uma totalidade funcional num momento dado no tempo, ou seja, a língua como sistema sincrônico homogêneo, rejeitando as manifestações (a fala) individuais.

Conforme essa concepção, a linguagem é vista com suas unidades básicas e suas regras. Enfatiza os fatores fonéticos, gramaticais e léxicos, permanecendo idênticos e normativos para todos os enunciados, formando um código. Essa concepção é chamada de objetivismo abstrato,

a linguagem é um sistema estável de formas normativas que a consciência individual já encontra pronto. As variações individuais e sociais da fala também são relativamente sem importância, são fortuitas e não afetam a unidade fundamental da linguagem enquanto sistema (Stam,1992, p.32).

Bakhtin, ao contrário de Saussure, toma a linguagem como um sistema não acabado, mas em um constante processo de transformação, permeado pelos fatores social, histórico, econômico, político. A linguagem não se apresenta ordenada, com regras e códigos, ela é confusa como a própria história. Bakhtin afirma que a fala está ligada às condições da comunicação, que estão ligadas às estruturas sociais.

A linguagem então não é vista só como um sistema abstrato, mas também como uma criação coletiva, parte de um diálogo cumulativo entre o "eu" e o outro, entre muitos "eus" e muitos outros.

Todo signo é ideológico, a ideologia é um reflexo das estruturas sociais, assim toda modificação da ideologia encadeia uma modificação da língua (Bakhtin, 1999, p.15)

Assim Bakhtin cria uma disciplina, a metalinguística ou translinguística, para estudar o enunciado. O enunciado é uma unidade da comunicação, enquanto que a palavra e a sentença são uma unidade da linguagem, este pertence a um universo de relações dialógicas inteiramente diferentes das relações puramente linguísticas.

O enunciado se produz num contexto que é sempre social, entre duas pessoas socialmente organizadas, não sendo necessária a presença atual do interlocutor, mas pressupondo-se a sua existência (Freitas, 1994, p.135)
O enunciado é sempre um diálogo. Cada enunciado se caracteriza por seus conteúdos e por seus sentidos.

A língua é a expressão das relações e lutas sociais, veiculando e sofrendo o efeito dessa luta, servindo de instrumento e material. A palavra veicula a ideologia, a palavra, portanto serve de indicador das mudanças.

A palavra se constitui em ato em campos discursivos, pois as tramas, significados e sentidos se transformam. O sujeito que fala transforma a sua própria fala ao falar, constituindo tramas de significados diversos. Então a mesma fala, deste outro locutor já não é a mesma fala, mas sim uma fala transformada. Diferentes sentidos são atribuídos a cada novo interlocutor constituído na diversidade de seus sentidos que, muitas vezes, se conflitua. Assim, é possível afirmar que os significados modificam-se de acordo com os diferentes contextos e sentidos e estes últimos, são carregados de valores.

A palavra está sempre orientada para que um destinatário possa ser (...) o mundo interno e o pensamento de cada pessoa têm sua estabilizada audiência social que compreende o meio ambiente em que razões, motivos, valores e assim por diante são moldados (...) a palavra é um ato bilateral. É determinada igualmente por aquele de quem ela é a palavra e por aquele a quem é destinada. Como palavra, é precisamente o produto de um relacionamento recíproco entre falante e ouvinte, expedidor e destinatário. Toda e qualquer palavra expressa um em relação ao outro (Bakhtin apud Clark \& Holquist, 1998, p.235).

A palavra, portanto, está intimamente ligada ao significado que lhe é dado. A palavra privada de seu sentido fica reduzida à sua realidade física. (Freitas, 1994 p.12).

É o contexto, a situação social, o lugar ocupado pelo falante que determinam qual o sentido que deve ser dado à palavra. Bakhtin considera a palavra como um fenômeno ideológico, que exercendo a função de signo, reflete e refrata a realidade.

A palavra é o lugar onde os valores de uma cultura, ou seja, os valores sociais se confrontam, de forma que os conflitos da língua refletem os conflitos de classe do sistema social. Os vários sentidos que a palavra denota é algo que vai sendo produzido de acordo com os processos de mudanças sociais, ou seja, os vários sentidos das palavras são construídos 
ao longo da história, em momentos singulares, pelos sujeitos sociais em interação verbal.

Na verdade não são palavras o que pronunciamos ou escutamos, mas verdades ou mentiras, coisas boas ou más, importantes ou triviais, agradáveis ou desagradáveis, etc.; a palavra está sempre carregada de um conteúdo ou de um sentido ideológico ou vivencial (Bakhtin, 1999, P. 95).

No que se refere a linguagem, palavra e significação, Bakhtin tem pontos que se intercruzam aos pressupostos de Vygotsky.

Vygotsky e Bakhtin nasceram em anos próximos (1896 e 1895) viveram num mesmo país - Rússia - mesmo contexto histórico e mesmo ambiente teórico-ideológico. Assim sendo, desenvolveram visões de homem e de mundo semelhantes. Apesar de seus objetivos diferentes, Bakhtin com sua construção de uma concepção histórica e social da linguagem e Vygotsky com uma psicologia histórico-cultural, são vários os pontos de encontro.

Começando pelo método dialético, em que os fenômenos devem ser estudados como um processo em movimento e mudança. Para os dois autores os fenômenos não devem ser vistos fragmentados, mas tudo está em movimento e assim deve ser observado, em sua totalidade. Compreendem portanto o homem como um conjunto de relações sociais. Nesse sentido, Vygotsky e Bakhtin rompem com a positividade de sua época, no qual o homem era considerado objeto e os fatos sociais como fragmento, uma parte. Conciliando a objetividade com a subjetividade, integram as duas.

Vygotsky sempre integra: pensamento e linguagem, aprendizagemdesenvolvimento, plano interno e plano externo, plano interpessoal e plano intrapessoal. Bakhtin por sua vez, no diálogo integra: enunciado e vida, falante e ouvinte, arte e vida, linguagem e consciência.

Estes dois autores veem o psiquismo humano através de uma perspectiva semiológica, sendo que o signo organiza e gera os processos psicológicos. A mediação semiótica é fundamental para a constituição do sujeito.

Para Bakhtin a fala, as condições de comunicação e as estruturas sociais estão também indissoluvelmente ligadas. Tanto o conteúdo a exprimir como sua objetivação externa são criados a partir de um único e mesmo material- a expressão semiótica (Freitas, 1994, p.138).

Para ocorrer esta mediação semiótica são necessários dois elementos: o instrumento que tem a função de regular as ações sobre os objetos e o signo que regula as ações sobre o psiquismo humano.

A função do signo consiste, antes de mais nada, em possibilitar ao ser humano conhecer o mundo e comunicar suas experiências na construção do universo sociocultural. $\mathrm{O}$ signo não muda nada no próprio objeto, mas sim reorganiza ou proporciona uma nova forma de o sujeito configurar seu mundo, sua atividades, suas relações (Sandri, 2001, p.41).

É através da mediação pela linguagem que se constitui a consciência. A relação do homem com os outros homens que o torna homem, o torna consciente. O outro é imprescindível para os dois autores.

Por isso tanto para Bakhtin como para Vygotsky a palavra é um poderoso instrumento semiótico no contato social e na regulação interpessoal e um modo puro de interação social.

Os dois veem a linguagem não apenas em seu aspecto comunicativo, mas como organizador do pensamento e planejador da ação.

Nesta perspectiva teórica foram analisadas as falas dos professores, buscando-se apreender os significados, sentidos e valores atribuídos ao Exame Nacional de Cursos.

O Exame Nacional de Cursos (ENC) foi implementado em 1995. Desde então, a cada ano novos cursos de graduação são submetidos a esta modalidade avaliativa. Trata-se de uma avaliação externa, cujo objetivo é avaliar conhecimentos, habilidades e competências dos acadêmicos no final de curso de graduação. O curso de pedagogia, a partir de 2001, integra a lista de cursos avaliados pelo MEC. Em sua sexta edição, o Exame Nacional de Cursos envolveu mais de 48 mil formandos, totalizando 595 cursos avaliados. $\mathrm{O}$ exame é realizado anualmente entre os meses de maio e junho e é condição obrigatória para a obtenção do registro do diploma.

O processo de avaliação das instituições de ensino superior é um tema atual e de relevância nacional. O ENC visa alimentar os processos de decisão e de formulação de ações voltadas para a melhoria dos cursos. 
Partindo da realidade de que os cursos de pedagogia no Brasil apresentam perfil diversificado, com ênfase nas diversas áreas de formação, a comissão de especialistas propôs novas diretrizes curriculares para o curso de pedagogia em 1999. Para a comissão de especialistas

as habilidades pedidas no exame procuram verificar algumas características gerais, comuns aos novos cursos. Existe uma grande preocupação em aliar a teoria e a prática. ${ }^{4}$

O aluno formando, além de prestar o exame, também participa de uma pesquisa, respondendo a um questionário. Este instrumento de diagnóstico tem como objetivo definir o perfil socioeconômico e cultural, como também conhecer as expectativas de mercado de trabalho do futuro graduado.

Após tabular e avaliar os dados computados, o MEC encaminha relatórios individuais de avaliação para cada aluno. Estes relatórios apresentam os resultados do desempenho individual de cada aluno e, também resultados da instituição, da região, do estado e do Brasil. Desta forma, o aluno pode estabelecer relações entre o seu resultado e os demais dados recebidos. Os coordenadores de curso e reitores das universidades também recebem relatórios que lhes permitem avaliar as condições do curso, de acordo com os resultados obtidos pelos alunos que prestam o exame.

Os relatórios são divulgados na imprensa e configura-se um ranking das Universidades Brasileiras. De acordo com relato dos professores:

Uma das desvantagens é essa avaliação ser classificatória, quem tem A quem tem B, gera uma questão punitiva e competitiva, pois quem tem A ganha mais verba quem tem B ganha menos, deveria ter um investimento: quem tem mais dificuldades, maiores deficiências. Prof 8

Outra desvantagem é a ideia de ranking qual o melhor curso, por meio de uma prova única, será que isso dá conta de avaliar de fato o curso? A qualidade do curso? Será que é só essa avaliação que precisa pra essa qualidade? Será que é por aí?... Prof 16

O ENC vem sofrendo inúmeras críticas de alunos, instituições de ensino superior e própria sociedade civil. Um dos argumentos que sustentam tais críticas é ao fato de constituir-se em um modelo de avaliação

\footnotetext{
${ }^{4}$ Revista do Provão. 2001
}

que desconsidera as especificidades dos cursos, em seus contextos regionais (o que inclui condições de oferta, perfil do aluno, infra-estrutura física e organizacional). Questiona-se, também, o fato de a avaliação ser feita em um momento único, valendo-se apenas de uma prova, aplicada aos acadêmicos. Estas criticas, referendadas em bibliografia recente ao campo da avaliação educacional, considera o ENC um retrocesso, uma vez que desconsidera a multiplicidade de concepções e formas de ensinar e desenvolver o conhecimento e avaliar o processo educacional (e não apenas o produto/resultado/prova).

Podemos perceber essas questões nas falas dos professores entrevistados:

... É o mesmo provão pra qualquer curso em qualquer lugar no Brasil. Prof 12

... Uma única forma de avaliação pra um país que apresenta tantas diversidades, então como essa avaliação vai contemplar essas diferenças regionais, diferentes propostas pedagógicas, perfil profissiográfico, mercado de trabalho, como uma única prova vai dar conta de todas essas questões. Prof 8

A prova é meio limitante, poderia ser mais aberto. Prof 14

O significado da padronização do ENC, atribuído pelos professores 12,8 e 14, denota que, para além da planificação das provas, os professores atribuem um sentido específico, qual seja, o fato do curso estar localizado em uma região específica do Brasil e como tal, não poder congregar toda a diversidade cultural e acadêmica contemplada nas questões do ENC.

De acordo com Bakhtin, o enunciado está sendo inserido em um contexto específico, carregado de sentidos e valores.

Entretanto, apesar de todas as críticas, o ENC é hoje, no Brasil, um fato e a imprensa encarrega-se de divulgar os resultados, classificando os cursos de graduação. Assim, as instituições de ensino superior têm reagido, organizando mudanças internas para se adequar aos critérios de avaliação externa promovida pelo MEC. Concordando ou não com os critérios levantados, as instituições procuram se adaptar ao sistema sob risco de descredenciamento de cursos e, até mesmo, descrédito frente a comunidade. Assim, principalmente nas instituições não públicas, são notórios os investimentos, tais como ampliação de laboratórios e bibliotecas, 
investimento na qualificação de professores etc, com objetivo de alcançar melhores índices no ENC.

No relato dos professores podemos perceber que ao se referirem as vantagens ocorridas com a implantação do ENC, veem uma melhoria na qualidade de ensino no curso e também um maior desempenho, interesse dos alunos com o seu processo de formação:

... O exame esta fazendo com que o curso e as instituições dêem mais credibilidade aos seus cursos, se preocupam com aquilo que está desenvolvendo no perfil, na formação profissional destes alunos... Prof 1

... Eu percebo uma evolução, uma boa melhorada de todo o processo... Prof 2

Houve uma melhor qualidade em nível dos cursos, uma melhor qualificação dos professores... Prof 3

A principal vantagem é que trouxe mais seriedade nos cursos em geral, todo mundo está mais preocupado com a qualidade. Prof. 4

... com certeza eu acho que trouxe possibilidades de estar melhorando a qualidade do ensino. Prof. 5

O professor 1 e 2 acreditam na melhoria do processo de ensino, o 3 afirma que a qualificação dos professores, logo, a sua também, foram alvo de melhorias com o adento do ENC. O professor 4 descreve que o curso ficou mais sério. Da mesma forma o professor 5.

... Penso também que um maior interesse dos alunos, um esforço bem melhor a nível profissional mesmo, durante o processo de formação deles... Prof. 12

O aluno já sabe que vai exigir dele um comprometimento... Prof 5

Eu vejo que houve um maior interesse dos alunos em relação aos conteúdos da sala de aula, até no sentido deles procurarem uma diversidade maior de livros para estarem lendo, etc... Prof. 15

O que precisamos agora é trabalhar o aluno para que ele seja reflexivo e antes não havia este interesse... antes era só cumprir as disciplinas... Prof 3
Este bloco de relatos dos professores permite inferir que os discursos estão carregados de sentidos e valores. São professores habilitados, que desempenham seus papéis com seriedade e compromisso.

Desse modo, há necessidade urgente em discutir e analisar o exame no que se refere aos seus aspectos práticos e técnicos, bem como suas concepções teóricas e implicações políticas.

A Portaria Ministerial ${ }^{5}$ estabelece as diretrizes gerais do Exame Nacional de Cursos para a área de pedagogia e pressupõe que o estudante tenha desenvolvido, ao longo do curso, capacidade de mobilização de conhecimentos e tecnologia para intervir efetivamente em situações pedagógicas concretas e de articulação, no processo de reflexão na escola, de recursos humanos, metodológicos, técnicos e operativos, mediante práticas participativas.

O Exame pressupõe ainda que o graduando tenha desenvolvido competências e atitudes investigativas, sabendo mapear contextos e problemas, argumentar e captar contradições em situações educativas e que possua sensibilidade ético-profissional, implicando responsabilidade social e atuação por uma sociedade justa e solidária. ${ }^{6}$

Sendo assim, uma das desvantagens citadas pelos professores pesquisados, refere-se aos alunos serem preparados para a realização do provão:

Eu acho que é uma excessiva preocupação muitas vezes das coordenações, das direções, dos professores em preparar esses alunos pra obter uma boa nota, o modo como a revisão é feita acaba sendo muito conteudista e pouco crítica, o aluno acaba decorando conteúdos e devolvendo na hora da prova. Prof 4

Uma das desvantagens vamos supor aqui no nosso curso é de repente numa preocupação excessiva como preparar os alunos para o provão... Prof 8

Os cursos, as universidades começam a preparar seus alunos pra esse exame, então me parece que há um certo desvio, um caminho diferente se não houvesse o provão. Prof 11

\footnotetext{
${ }^{5}$ Portaria ${ }^{\circ} 012$, de 04 de janeiro de 2001.

${ }^{6}$ Idem
} 
A formação de professores vem vivenciando um momento de transição e mudanças curriculares, o Curso de Pedagogia passa por um amplo debate nacional que se discute o destino do curso.

O Exame Nacional de Cursos tem sido amplamente discutido por educadores e responsáveis por políticas educacionais. A conferencista, Prof ${ }^{a}$. Mérion Campos Bordas (Representante do MEC/SESU) pontua sobre o envolvimento e compromisso das instituições formadoras de disponibilizarem à sociedade um profissional em constante busca de aperfeiçoamento, com vistas a aprofundar e/ou diversificar sua formação inicial em função das demandas sociais de educação e das inovações que a evolução científica e tecnológica colocam a serviço da ação pedagógica.

Para tanto, a relevância desse estudo, através dos resultados poderão contribuir e subsidiar ações significativas no projeto pedagógico e no currículo dos cursos de formação de professores.

É através das relações dialógicas, nos atos de fala que estes professores constróem suas significações. O meio ambiente que estes atos de fala surgem é o que Bakhtin chama de psicologia do corpo social.

É neste elemento que se acham submersas todas as formas e aspectos da criação ideológica ininterrupta: as conversas de corredor, as trocas de opinião puramente fortuitas, o modo de reação verbal face às realidades da vida e aos acontecimentos do dia a dia, o discurso interior e a consciência auto-referente, a regulação social, etc. (Bakhtin, 1999, p.42)

Outro item significativo no discurso dos professores, em relação as desvantagens é os conteúdos do ENC passarem a fazer parte do currículo do curso, ou outras vezes os professores deixarem de lado os conteúdos contemplados no currículo com a preocupação de abordar, os conteúdos contemplados no provão:

...Eu penso que seja uma preocupação excessiva com aquelas diretrizes, aqueles conteúdos que foram apontados e que caíram no provão, os cursos se voltaram para esse currículo e acabaram perdendo sua própria identidade acontecendo uma certa uniformização dos cursos na FEBE... Prof 2

Nosso curso acabou focando um olhar para algumas coisas que eram pertinentes ao provão... existem alguns conteúdos, alguns temas que o provão busca, então nos precisamos dar conta daquilo, não sei se chega a ser uma desvantagem, mas é uma regulamentação que não é interna. Prof 13

\section{Considerações finais}

Ao que parece, o discurso dos professores é homogêneo e se assemelham as discussões realizadas por educadores e responsáveis por políticas educacionais em todo o Brasil.

Os professores são os principais protagonistas destes discursos e este por sua vez é construído na realidade que os cercam, o curso de Pedagogia da FEBE.

Este curso por sua vez está ligado a todas as discussões que ocorrem a nível nacional no que diz respeito ao Exame Nacional de cursos, portanto há fios dialógicos que se intercruzam entre os discursos de enunciatários externos e os professores desta instituição.

O contexto histórico transforma a palavra do dicionário em fios dialógicos vivos que refletem e refratam a realidade que a produziu. $\mathrm{O}$ processo de reflexão e refração pode ser assim explicado:

A palavra quando entra na arena discursiva, passa por constantes transformações. Ela é lançada pelo locutor, mas quando devolvida pelo interlocutor, que já tem mudado de posição, passando a ocupar a posição daquele, não é mais a mesma. É a palavra do primeiro locutor, que a devolve com uma carga a mais de sentido. Pode afirmar que, em situação de uso, a palavra se vai revestindo de sentidos, tons e valores. Ela é prenhe de significados (Barbosa, 2002, p.l).

Bakhtin se refere as palavras como sendo verdades ou mentiras que pronunciamos ou escutamos, importantes ou triviais, carregada de sentido e significado.

No que se refere as significações realizadas pelos professores, a respeito das desvantagens, o que mais se destaca é a questão da competitividade entre as universidades ou seja, a classificação, o ranking entre os cursos. 
Outra variável importante é no que se refere aos conteúdos englobados no ENC. Os professores enfocam estes conteúdos em sala de aula, que por sua vez acabam fazendo parte do currículo.

Uma desvantagem que fica evidente no discurso dos professores é a padronização da avaliação. Segundo relato de professores este método desconsidera as especificidades dos cursos em seus contextos regionais, ainda que não permite a avaliação sendo um processo mas um momento único. prova:

Por fim outra desvantagem é preparar os alunos para a realização da

O aluno acaba decorando conteúdos e devolvendo na hora da prova. Prof 6

Outro aspecto que gostaríamos de enfatizar são as significações a respeito das vantagens observadas pelos professores com a implantação do ENC.

Estes alegam que o grande benefício vivenciado é a preocupação com a qualidade dos cursos de ensino superior. Sendo este o objetivo traçado pelo MEC ao instituir o Exame Nacional.

A principal vantagem é que trouxe mais seriedade nos cursos em geral, todo mundo está mais preocupado com a qualidade. Prof 4

Declaram também que uma das vantagens, está ligada a um maior desempenho e interesse dos alunos com sua formação, se comprometendo mais a atividades como pesquisa, buscar literaturas diversificadas, sendo crítico e reflexivo.

Percebemos com esta pesquisa que há uma discussão reflexiva no que diz respeito à implantação do Exame Nacional de Cursos por parte dos professores da FEBE-Brusque.

Conforme o referencial adotado, concluímos que a palavra traz as marcas históricas, sociais e culturais, a gama de sentido que ela denota é algo que vai sendo produzido de acordo com os processos de mudanças sociais, ou seja, os vários sentidos das palavras são construídos ao longo da história, em momentos singulares, pelos sujeitos em interação verbal.
Referências

Bakhtin, M. M (1999) Marxismo e filosofia da linguagem. $9^{\mathrm{a}}$ ed. São Paulo: Hucitec.

Brait, Beth (org.) (1997) Bakhtin, dialogismo e construção do sentido. Campinas-SP: Editora da UNICAMP.

Bodgdan, Robert e Biklen, Sari (1994) Investigação qualitativa em educação: uma introdução à teoria e aos métodos. Trad. Maria Jalvarez; Sara B. dos Santos e Teimo M. Baptista. Portugal: Porto.

Clark, Katerina \& Holqust, Michael (1998) Mikhail Bakhtin. São Paulo: Perspectiva.

Daniels, Harry (orgs) (1994) Vygotsky em foco: Pressupostos e desdobramentos. Campinas/ SP: Papirus.

Freitas, M.T.A. (1994) Vygotsky e Bakhtin - Psicologia e educação: um intertexto. São Paulo: Atica.

(1994) O pensamento de Vygotsky e Bakhtin no Brasil. Campinas: Papirus.

Molon, S. I (1999) Subjetividade e constituição do sujeito em Vygotsky. São Paulo: EDUC.

Oliveira, R.M.Z. (1995) A criança e seu desenvolvimento: Perspectivas para se discutir e educação infantil. São Paulo: Cortez.

Sandri, Gianine (2001) A constituição do sujeito nas relações de Gênero: considerações a partir da perspectiva histórico-cultural. In: Contrapontos/Universidade do Vale do Itajaí. Ano 1, n 2, out.

Schlindwein, Luciane Maria e Petri, Claudia Maria (2000) As classes de aceleração das séries iniciais do ensino fundamental nos municípios de Itajaí e Balneário Camboriú: Conhecendo a realidade. Relatório Final de Pesquisa, UNIVALI.

Stam, Robert (1992) Bakhtin da teoria literária à cultura de massa. São Paulo: Ática.

Smolka A. L .B \& Góes M. C. R. (orgs) (1993) A linguagem e o outro no espaço escolar: Vygotsky e a construção do conhecimento. Campinas, SP: Papirus. 
Educação e saúde: considerações a respeito da atuação interdisciplinar em uma comunidade escolar ${ }^{1}$

\author{
Leia Viviane Fontoura ${ }^{2}$ \\ Salete Galvan \\ Adir Luiz $\mathrm{Stiz}^{4}$ \\ Deyse Ferreira ${ }^{5}$
}

\section{O início do PAESCE}

Desde 1987, a UNIVALI vinha desenvolvendo atividades na saúde do escolar, nas escolas da microrregião do Vale do Itajaí, envolvendo os docentes e discentes do curso de Enfermagem. Em 1996, o curso diversificou seus campos de intervenção na comunidade, mantendo ainda uma escola pública estadual de educação básica. O desenvolvimento das atividades na escola priorizava o levantamento de problemas de saúde através de exames físicos, testes de acuidade visual e auditiva, encaminhando os casos alterados para serviços especializados e ministrando palestras com turmas de alunos para a prevenção de doenças.

O Centro de Educação Superior de Ciências da Saúde, em 1999 propôs a integração dos projetos, nos diversos cursos, para otimização e desenvolvimento da cultura interdisciplinar. Ingressaram neste projeto, os cursos de Psicologia, Odontologia e Fonoaudiologia. O projeto tomou então nova dimensão saindo do paradigma assistencial na concepção de saúde do escolar e construindo em sua práxis a promoção de saúde, implementando ações com os sujeitos envolvidos nessa instituição.

\footnotetext{
Participaram da elaboração deste artigo as bolsistas: Ana Paula Boeira Lencina, Adriane Baggio, Alessandra Sebben Covolo, Ariane Mezadri, Carolina Scabrin Kriger, Elaine Rocha Pinheiro, Emanuella Sauto Arrosi, Estela Maria Ribeiro e Tatiany Oliveira Molina.

Psicóloga. Professora do Curso de Psicologia da UNIVALI e FURB. Mestre em Educação. Responsável pelo PAESCE.

${ }^{3}$ Enfermeira. Professora do curso de Enfermagem na UNIVALI. Mestre em Avaliação e Inovação Tecnológica.

${ }_{5}^{4}$ Odontólogo. Professor do curso de Odontologia da UNIVALI. Mestre em Saúde Coletiva.

5 Fonoaudióloga. Professora do curso de Fonoaudiologia da UNIVALI. Mestre em

Distúrbios da Comunicação.

${ }^{6}$ Projeto de Atenção à Educação e Comunidade Escolar.
}

A equipe interdisciplinar é composta por um professor e dois bolsistas de Psicologia, Enfermagem, Odontologia e Fonoaudiologia, que buscou a sua integração e discutiu sobre as contribuições das ciências envolvidas e a forma de articulação entre elas para as ações, estabelecendo como objetivo: contribuir para o desenvolvimento da comunidade escolar, traçando e executando ações de âmbito preventivo/educativo na promoção da saúde integral.

Para a realização do planejamento das ações, a equipe do PAESCE se reúne quinzenalmente e cada professor com seus bolsistas semanalmente.

Estes atuam na escola diariamente nos dois turnos de funcionamento: matutino e vespertino, com orientação dos professores da Universidade. A população envolve duas orientadoras pedagógicas, uma supervisora, uma diretora, uma secretária, dezenove professores e aproximadamente quatrocentos alunos.

Compreendemos que a escola é uma instituição sempre alvo de muitas investigações em várias ciências. Martinez (1996) identificou a escola como um espaço vital para a promoção de saúde, destacando que tal promoção é uma função do conjunto da sociedade e das suas instituições. De acordo com a autora, esta nova concepção de saúde possui uma íntima relação com o processo educativo. A partir dessa concepção podemos analisar o papel da escola, como uma das instituições básicas da sociedade no processo de desenvolvimento da saúde. Entendemos, então, que nosso objeto interdisciplinar é a promoção de saúde, na qual a interseção seja a de um agente de mudanças das relações sociais. ${ }^{7}$ As ações desenvolvidas estão calcadas na análise das relações concretas que se estabelecem na escola, procurando gerar condições para, como propõe Patto (1984, p.12), "que se mantenham acesos à capacidade de pensar e o desejo de dignidade numa sociedade que conspira o tempo todo contra isso".

Frente a esta postura, a equipe integrou-se nas atividades curriculares, com base na abordagem institucionalista, construindo a análise da instituição através da observação no cotidiano ${ }^{8}$ da escola, nas salas de aulas,

${ }^{7}$ Compactuando com uma psicologia crítica, confira autores como Patto (1984 e 1997) Andaló (1990), Tanamachi, Rocha e Proença (2000), entre outros.

${ }^{8} \mathrm{O}$ entendimento de cotidiano é apoiado no referencial de Agnes Heller, segundo a autora: “(...) a vida cotidiana é a vida de todo homem (...) o homem participa da vida cotidiana com 
nos intervalos, nas reuniões com professores, direção e especialistas bem como conversas individuais e intervenções em situações nos grupos de alunos e professores.

A análise da instituição ${ }^{9}$ revelou que há dificuldades na realização de atividades coletivas, com problemas no relacionamento interpessoal dos vários atores sociais da comunidade escolar. Entre estas, destacam-se as relações autoritárias, que entendemos como relações de poder disciplinar, de organização do tempo e espaço. ${ }^{10}$ As ações pedagógicas e atitudes da maior parte dos professores, em sua cotidianidade, indicaram incongruência com a proposta do plano político pedagógico da escola. ${ }^{11}$

Após a apresentação e discussão desses resultados, sempre provisórios, junto aos profissionais da escola, traçamos ações conjuntas para atuarmos na direção de que os sujeitos promovam sua autonomia, enfocando as relações como abertura de espaços em que as diferenças possam ser explicitadas e analisadas. Esta devolutiva oficial ocorreu a cada início de ano (2000, 2001 e 2002), nas reuniões de planejamento dos professores, onde discutimos nossos avanços e impasses. Dessa forma, trabalhamos numa postura interdisciplinar com os grupos de alunos e professores implantando e implementando atividades que conduzam a concretização do plano político pedagógico da escola. Também realizamos

todos os aspectos de sua individualidade, de sua personalidade. Nela, coloca-se em funcionamento todos os seus sentidos, todas as suas capacidades intelectuais, suas habilidades manipulativas, seus sentimentos, paixões, ideias, ideologias. $\mathrm{O}$ fato de que todas as suas capacidades se coloquem em funcionamento determina também, naturalmente, que nenhuma delas possa realizar-se, nem de longe, em toda sua intensidade. O homem da cotidianidade é atuante e fruidor, ativo e receptivo, mas não tem nem tempo nem possibilidade de se absorver inteiramente em nenhum desses aspectos; por isso, não pode aguçá-los em toda sua intensidade. (Heller, 1992, p.17).

${ }^{9}$ É importante esclarecer que a análise da instituição não é uma tarefa que se esgota em um período de tempo, mas é compreendida como uma abordagem de trabalho, realizada dinamicamente na própria cotidianidade. Compactuando com Rocha (2000, p.186), “(...) a nossa perspectiva está na abertura de espaços que permeiam à 'comunidade escolar, da qual faz parte também o psicólogo, discutir suas implicações com a construção do cotidiano educacional, envolvendo a própria formação, relações, diversidade de posições frente ao processo, assim como nas insatisfações, demandas e alternativas".

${ }^{10}$ Conferir Michel Foucault, na obra Microfísica do Poder, 1995.

${ }^{11}$ Para maiores detalhes ver Fontoura; Galvan, e Didoné, (2001). atividades específicas de cada Curso $^{12}$ atendendo as demandas da comunidade.

\section{As ações desenvolvidas}

O trabalho na escola foi permeado por uma série de avanços e retrocessos, o que acreditamos fazer parte de todo contexto institucional, que é palco de conflitos e resistências. Segundo Petitat (1994) a escola apresentase como uma resposta a certas necessidades e condições, favorecendo a invenção, ou seja, a criação dos sujeitos que vivem em sociedade.

Compactuamos que a educação escolar só pode ser pensada em seu contexto histórico-cultural, na trama de relações e suas instituições. Concordando com Severino (1991, p.36) ao escrever que:

A educação pode ser uma prática de intervenção na realidade social, é um fenômeno multifacetado composto por um conjunto complexo de perspectivas e enfoques. Não pode, portanto, ser considerada como uma ciência isolada nem tampouco apreendida mediante categorias de um único campo epistemológico, já que várias disciplinas autônomas convergem para a constituição de seu objeto. Ou seja, a prática pedagógica é influenciada por múltiplas dimensões: social e política, filosófica, ética, histórica etc.

Neste sentido, as atividades desenvolvidas com as turmas de alunos foram planejadas e executadas sempre com a participação, direta ou indireta, dos professores. Passaremos a apresentar, brevemente, algumas das ações desenvolvidas nestes três anos e meio de existência do PAESCE.

No ano de 2000 foi realizado um levantamento com todas as turmas de alunos, para que pudéssemos obter dados acerca de como percebem a escola. Solicitamos que eles colocassem como é sua escola e como gostariam que ela fosse, bem como sugestões para as melhorias. A metodologia utilizada com os alunos de $3^{\mathrm{a}}$ à $8^{\mathrm{a}}$ série foi através de discussão em pequenos grupos, confecção de cartazes e apresentação para a turma. Com os alunos da préescola à $2^{\mathrm{a}}$ série, foi solicitado que desenhassem e explicassem.

\footnotetext{
${ }^{12}$ Como a escovação, revelação de placas e aplicação de flúor; os exames de pediculose e escabiose; os exames de acuidade visual e auditiva; os procedimentos de enfermagem quando alguém se fere na escola e encaminhamentos médicos.
} 
As questões levantadas pelos grupos de quinta à oitava série e classe de aceleração giraram em torno de: bons professores, boas atividades oferecidas na escola, bons colegas, inexistência de um grêmio estudantil, violência, limpeza inadequada, professores desinteressados, diretora autoritária, poucas atividades extracurriculares, materiais precários para portadores de necessidades especiais, estrutura física precária (quadra, mato, laboratório de ciências), biblioteca defasada, desorganização de professores (absenteísmo e troca) e inexistência de aulas de reforço. As sugestões dadas pelo grupo foram: aproveitamento do espaço físico, expulsão de alunos desinteressados, compra de materiais didáticos, ampliação da biblioteca, criação de um laboratório de ciências, respeito aos professores e aos alunos, diversificação no cardápio da merenda e dos produtos alimentícios oferecidos na cantina, promoção de eventos e manutenção de portas fechadas durante os intervalos.

Em relação ao grupo de pré-escola a quarta série, as questões levantadas foram: é bom estudar nesta escola, bons professores, gostam das orientadoras educacionais, aula de Educação Física boa. Expressaram descontentamento com a estrutura física, mais especificamente com a desativação do parquinho, a quadra, a inadequação dos bebedouros (alto demais para a maioria alcançar), a falta de materiais na sala de jogos; a limpeza insuficiente nos banheiros e a merenda ruim. Relataram ainda, o desrespeito entre colegas e professores e a direção considerada muito "braba" (sic). As sugestões foram: o plantio de flores, a ativação do parquinho, aulas de computação, passeios pedagógicos, reformar a quadra, adequar os bebedouros, variar o cardápio da merenda e a criação conjunta das normas de convivência.

Durante o levantamento, constatamos que os alunos de quinta à oitava sene, incluindo a classe de aceleração, demonstraram um grande descontentamento acerca do autoritarismo da direção atual, pedindo uma mudança de postura ou o seu afastamento. Do mesmo modo que falavam do autoritarismo da direção, solicitaram a expulsão de alguns colegas que "perturbam a paz" e o fechamento das portas da escola no período do recreio. Observamos a resistência de alguns alunos em se comprometer com as mudanças que sugeriram, direcionando estas aos demais, permanecendo sempre no seu "eu". Apesar de citarem a inexistência de um grêmio estudantil, não houve mobilização para a efetivação de um, mesmo com todo o apoio que o grupo de bolsistas insistiu em oferecer. Tais eventos nos são elucidados por Rocha (2000, p.195) ao escrever que:

O modo de subjetivação que é veiculado pelas instituições sociais não constitui somente uma transmissão de significações, um conjunto de ideias impostas. Trata-se de sistemas de conexões direta entre as grandes máquinas produtivas, as estruturas de controle social, e as instâncias psíquicas que defendem a maneira de perceber o mundo. $\mathrm{O}$ sistema de significação dominante atravessa a conformação do sujeito social, configurando modos de valorização, de sensibilidade, de desejo e de representação do mundo.

Frente a este levantamento e após reunião com os professores e direção, traçamos ações que acreditamos ter fugido à lógica dominante intercedendo “(...) pela polissemia da expressão (...)” (Rocha, 2000, p.194).

Com as turmas de $5^{\mathrm{a}}$ à $8^{\mathrm{a}}$ séries e classe de aceleração foram realizadas as seguintes atividades:

Oficinas com os temas transversais: Em observações às aulas dos professores, a convite ou por sugestão da equipe, constatamos que as aulas de Religião tinham como conteúdo os temas transversais preconizados pelos Parâmetros Curriculares Nacionais (BRASIL/MEC, 1997). Sendo esta a única disciplina a tratar dos temas de: Ética, Pluralidade Cultural, do Meio Ambiente, da Saúde, da Educação Sexual, do Trabalho e Consumo. Além disso, foi observado também que havia problemas de relacionamento entre alunos/alunos e alunos/professores

Diante dessa realidade, optou-se então em trabalhar o conteúdo dos Temas Transversais através de oficinas, realizadas extraclasse aos sábados Essa estratégia, embora não sendo àquela sugerida pelo MEC, manteve as características de interdisciplinaridade e transversalidade. Também oportunizou aos alunos discutirem esses conteúdos tendo como suporte teórico o próprio conhecimento e experiências, a realidade escolar e os problemas pessoais e interpessoais existentes. Sendo assim, foram planejados cinco oficinas com os seguintes temas: Saúde: Projeto de vida ou Projeto de Morte?; Meio Ambiente: o EU, o NÓS, e a Preservação do Meio Ambiente; Sexualidade; Ética: meus direitos e meus deveres; Trabalho e Cidadania: Cresci e Agora? 
Como resultados dessa experiência destaca-se a sensibilização dos alunos quanto à contribuição de cada um na determinação das características do meio escolar, familiar e comunitário em que estão inseridos; na sensibilização em relação à importância da formação para a concretização dos projetos de vida; a discussão de vários problemas pessoais e familiares que eram do conhecimento dos colegas; discussão dos problemas existentes na escola e apresentação de propostas para solucioná-los.

Matemática divertida: Por solicitação da professora de matemática, desenvolvemos uma série de jogos, onde as estratégias de ação para as atividades relacionadas à disciplina visaram, também, incentivar a cooperação e integração dos alunos, em primeira instância nas turmas e em segundo momento, entre as séries. Esta atividade revisou, por aproximadamente um mês, os conteúdos ministrados de forma lúdica, oportunizando as turmas a conhecerem-se melhor, alcançando os objetivos propostos para o trabalho. A professora da disciplina adotou alguns dos jogos como prática pedagógica.

Discutindo a sexualidade: Em reunião com os professores, estes solicitaram um trabalho sobre a sexualidade, tendo em vista os comentários que ouviam dos alunos, indicando falta de conhecimento e necessidade de um espaço para discussão. Visitamos todas as salas de aula e propomos aos alunos alguns encontros para discutirmos sobre o tema. Com aprovação de todas as turmas, solicitamos questões e dúvidas para serem entregues no dia seguinte. Recolhemos as questões de cada turma e constatamos um grande número de dúvidas, tabus e mitos.

Realizamos três encontros com cada turma, onde foram tratadas as suas especificidades. No primeiro encontro optamos pela técnica expositiva dialógica, fazendo uso de vídeo e material impresso. No segundo e terceiro encontro debatemos sobre questões que eles propuseram.

Projeto da Paz: cidadania e alteridade. Uma das propostas do plano político pedagógico da escola, que envolvia o direcionamento da Secretaria Estadual de Educação, implicava na apresentação periódica na comunidade de uma atividade alusiva à paz e o desenvolvimento de ações no cotidiano da instituição. Frente as frequentes queixas dos professores da falta de limites dos alunos e as observações dos materiais e apresentações do tema da paz, que não os envolvia diretamente, mas a contextos mais amplos no mundo, como a guerra, a destruição do meioambiente, a agressão nos jogos de futebol, os assassinatos entre outros, propomos uma intervenção em cada turma.

Realizamos, em média cinco encontros, com periodicidade quinzenal. Nestes, tentamos criar um espaço de mediação para o abandono de posturas defensivas e na criação de dispositivos de comunicação mais transparente. Discutimos sobre as significações de paz e violência para eles, os conceitos de incivilidade, ${ }^{13}$ cidadania e alteridade, ${ }^{14}$ bem como a implicação e responsabilidades de suas ações. Para desencadear as discussões, lançamos mão das técnicas de dinâmica de grupo, dramatizações e desenhos.

Em algumas turmas houve a pronta implicação e adesão dos alunos, sendo observado uma diminuição das brigas e constantes xingamentos. Entretanto, em outras, os alunos demonstraram resistências. Apesar de terem concordado com o desenvolvimento do trabalho, a expressão que presenciamos foram cenas de incivilidades, como às agressões verbais e físicas entre eles e a falta de disponibilidade para escutar o colega. As professoras que acompanharam o trabalho insistiam em disciplinar a turma, não compreendendo os motivos que nos levavam a dispensar as suas

${ }^{13}$ Laterman refere que o termo violência, da forma como é veiculado socialmente, não é
suficiente para explicar o que ocorre dentro das escolas. Considerando que necessariamente
não são crimes e delitos o que gera um clima de violência e insegurança no espaço escolar,
mas sim, atos de incivilidades. Neste sentido, a autora citando Debardieux, situa o conceito
de incivilidade: "Por incivilidade se entenderá uma grande gama de fatos indo da
indelicadeza (...) ao vandalismo (...). As incivilidades mais inofensivas parecem ameaças
contra a ordem estabelecida transgredindo os códigos elementares da vida em sociedade, o
código de boas maneiras. Elas podem ser da ordem do barulho, sujeira, impolidez, tudo que
causa desordem. Não são então necessariamente comportamentos ilegais em seu sentido
jurídico mas infrações à ordem estabelecida, encontradas na vida cotidiana. (...) Indo mais
além, as incivilidades, pela impressão de desordem que geram, são para os que as sofrem a
ocasião de um compromisso, uma defesa em causa da organização do mundo. Através delas
a violência se torna uma crise de sentido e contra sentido. Elas abrem a ideia do caos".
(Laterman, 2000, p.37).
14 Ao discutir o conceito de cidadania Sawaia recupera uma dimensão deste conceito não
incorporada da modernidade contemporânea que é o de alteridade. "A maioria das definições
e o uso corrente deste conceito não inclui a ideia de individualidade, autonomia e
pluralidade. Assim, cidadania normalmente é pensada como a relação existente entre o
cidadão e o Estado, no qual este deve proteger e em troca o cidadão deve obedecer. Este tipo
de relação é homogeneizadora e leva a heteronomia, pois o cidadão coloca-se sobre a tutela
do Estado". (1994, p.147). 
intervenções, mesmo sendo explicado várias vezes. Alguns alunos também sugeriam que gritássemos ou déssemos uma punição, também explicávamos para eles os motivos de nossa postura, pois desta forma, jamais conseguiríamos romper com a lógica adotada, não alterando a forma de lidar com o poder.

Jogo da saúde: Aproveitando os conteúdos da disciplina de ciências e alguns encontros que realizamos nas turmas para trabalharmos com temas relativos aos cuidados com a saúde, confeccionamos e aplicamos um jogo que teve como inspiração o "Jogo do Milhão", do programa comandado por Sílvio Santos na emissora do SBT.

As turmas foram organizadas em equipes. Cada pergunta continha três respostas em que o grupo deveria escolher a correta para ganhar o ponto. Se houvesse dúvidas, poderiam recorrer às placas. No início do jogo as respostas eram aleatórias, sem o consenso da equipe. Com a perda de pontos mudaram a estratégia, entendendo que era necessário discutir a questão para votarem na resposta da equipe.

Em algumas turmas foi percebido que a apresentação das opções das respostas tornava algumas questões muito fáceis de serem respondidas e, por isso, foram retiradas, passando a ser feita apenas a pergunta. Este procedimento propiciou a discussão da resposta correta nas equipes, favorecendo a discussão, o questionamento e maior envolvimento na tarefa. A cada pontuação errônea, a turma era instigada a verbalizar qual a resposta correta. Nas dúvidas as bolsistas intervinham, esclarecendo. De forma geral esta atividade propiciou um exercício de comunicação e respeito ao conhecimento e opinião do outro. Os alunos avaliaram positivamente e sugeriram a continuação de atividades semelhantes.

Gincana do conhecimento: Atendendo as expectativas dos alunos frente à solicitação realizada após o jogo da saúde, realizamos uma gincana. Foi elaborada com a participação dos professores, que confeccionaram perguntas e três opções de respostas dos conteúdos ministrados ao longo do bimestre. Além dessas, acrescentamos questões referentes aos cuidados com a saúde.

A atividade foi desenvolvida por turmas, no pátio da escola. A equipe ganhava pontos pelo acerto das questões e também pela execução correta e/ou mais rápida de tarefas sorteadas. Estas envolviam uma série de ações, tais como: colocar o nariz no palhaço, com uma venda nos olhos; passar o balão entre as pernas, ou por cima da cabeça, até que a primeira pessoa da fila ficasse em último lugar e muitas outras brincadeiras.

Os alunos participaram e se empolgaram com a atividade. Em geral acertavam as respostas, ficando o conteúdo relativo ao Estatuto da Criança e do Adolescente o que mais gerou dúvidas e erro, sendo estas esclarecidas e discutidas. Os professores ficaram satisfeitos com o desempenho de seus alunos e avaliaram a atividade positivamente.

Todas as ações realizadas com os alunos foram desenvolvidas com a intenção de contribuir para o conhecimento dos conteúdos e principalmente, enfocando as relações, abrindo espaços para o novo, tentando quebrar a lógica homogeneizante e cristalizada do tédio ${ }^{15}$ na cotidianidade da escola.

Com os professores foram realizadas as seguintes atividades: No final do ano de 2000, solicitamos uma reunião com todos os professores, especialistas e direção. Nosso objetivo foi de realizar um levantamento para que pudéssemos obter dados acerca de como percebem a escola, investigando os pontos comuns com os resultados obtidos dos alunos e analisar com os professores a viabilidade de mudanças sugeridas.

Dividimos o grupo em pequenas equipes, nas quais deveriam descrever a escola que temos e a escola que queremos, da mesma forma que foi realizado com os alunos. Foram confrontados os dados dos grupos, sintetizados e discutidos. Houve concordância entre os professores e alunos nos seguintes pontos: o autoritarismo da diretora, a precariedade da limpeza, as faltas em excesso.

As discrepâncias também se tornaram evidentes. Segundo os discursos dos professores, buscavam alunos críticos, produtores e pessoas capazes de "apreender" (sic). Entretanto, em sua prática, tratavam os alunos como seres a serem moldados, que deveriam apenas se comportar como expectadores. Tais atuações apareceram fortemente impressas nas falas dos alunos.

Em relação ao descontentamento dos alunos, acerca da depredação e da falta de higiene da escola, entendemos que não há consciência e apropriação do espaço escolar como seu, mas representa a diretora e/ou os

\footnotetext{
${ }^{15}$ O termo "tédio" que referimos esta de acordo com a posição e Marisa Lopes da Rocha, no texto Educação em tempos de tédio: um desafio à micropolítica (2000).
} 
professores, pois, os próprios alunos acabam por depredá-la e sujá-la. E claro que esta hipótese está calcada, também, nas observações das práticas pedagógicas no exercício do poder disciplinar.

Quanto às possibilidades de atendimento às sugestões dos alunos, algumas foram sendo realizadas ao longo do ano seguinte, tais como: implementação de atividades extraclasse, reforma do parquinho, plantio de flores e folhagens, melhora na limpeza da escola e campanha junto aos alunos para preservá-la, o portão passou a ser fechado, porém não só na hora do intervalo como o solicitado, mas logo após o início das aulas.

Nesta reunião os professores também sugeriram que os encontros com o PAESCE passassem a ser sistemático — uma vez por mês — a fim de serem discutidos temas específicos e acompanhamento do trabalho.

Reuniões mensais: A partir do ano de 2001, a direção da escola disponibilizou duas horas aulas, uma vez ao mês, para que discutíssemos temas específicos que foram solicitados pelo grupo.

O primeiro tema foi um pedido da direção que desejava sensibilizar alguns dos professores para receberem alunos portadores de necessidades especiais. Trabalhamos com uma vivência, seguida de debate. As questões de resistências estavam situadas nas dúvidas quanto aos procedimentos didáticos. Como houve o esclarecimento que haveria o assessoramento de profissionais, os professores se tranquilizaram.

O tema da sexualidade gerou dois encontros, onde foram expostos os objetivos, conteúdos e metodologia da educação sexual. Os professores tiraram dúvidas a respeito de formas de contágio, sintomas e cuidados no tratamento de doenças sexualmente transmissíveis, da diversidade de métodos preventivos existentes, bem como no manejo com situações que consideravam embaraçosas frente aos alunos. Foi apresentada, também, uma pesquisa realizada no primeiro semestre de 2001 por um grupo de acadêmicos da UNIVALI. Esta tratou do comportamento dos adolescentes em relação ao início da vida sexual, enriquecendo os docentes quanto a informações que permitiram conhecerem melhor o perfil dos alunos.

A temática da violência foi discutida através da significação que os professores remetem ao termo. Estes apresentaram uma série de situações como a agressão física, a depredação da escola e as relações interpessoais. Este trabalho implicou na proposta do projeto da paz desenvolvido com os alunos.

O tema da saúde foi trabalhado a partir da concepção dos professores e apresentado cartazes que a equipe do PAESCE havia realizado em atividade com os alunos. Estes puderam perceber que os alunos entendem a saúde de forma integrada, crítica e despojada da díade saúde-doença. Outro tema trabalhado e implicado com a saúde foi o de impostação vocal, entendendo que a docência exige um cuidado especial com a voz.

Curso de aperfeiçoamento: Atendendo ao pedido do grupo de professores e da direção da escola, realizamos um curso com duração de 16 horas/aulas, subsidiado pela Secretaria Estadual de Educação, para o aperfeiçoamento do corpo docente. O tema solicitado pelo grupo foi à indisciplina. Organizamos o debate deste tema através das concepções de aprendizagem e desenvolvimento humano, refletindo o que é indisciplina para cada concepção. Realizamos encenações e paródias envolvendo situações do cotidiano escolar e ao final, um debate a cerca da compreensão e práticas pedagógicas utilizadas pelos professores. Este debate gerou polêmica, pois, muitos não tinham percebido, até então, as discrepâncias entre o plano político-pedagógico da escola e como atuam cotidianamente, bem como a noção das teorias que na realidade norte iam sua prática pedagógica. Foi possível então, discutir as significações de indisciplina.

Reuniões de replanejamento: Esta atividade veio em decorrência das discussões do curso de aperfeiçoamento. Foi percebido pela equipe de professores da $5^{\mathrm{a}}$ à $8^{\mathrm{a}}$ série, a necessidade da abertura de um espaço para trocas de informações a respeito do corpo discente e a busca conjunta de soluções aos conflitos enfrentados em sala de aula, bem como de planejarem os conteúdos de forma mais integrada. Estas reuniões que foram chamadas de replanejamento aconteceram uma vez ao mês, durante um semestre letivo. Como resultado desta proposta, observamos dificuldades em construírem e manterem este espaço de comunicação, sendo utilizado para informes de ordem administrativa.

Assessoria as professoras da pré-escola à $4^{a}$ série: Após a primeira reunião do ano letivo de 2002, as professoras pediram o acompanhamento das bolsistas do curso de Psicologia para as turmas da pré-escola à quarta 
série, a fim de contribuírem com a elaboração de estratégias conjuntas frente às dificuldades encontradas em sala de aula.

Foram feitas observações em sala de aula e conversado com as professoras a respeito da busca de alternativas mediadoras para as diversas situações observadas. Entretanto, constatamos que o desejo das mesmas não as implicava nas ações. Quando perceberam que a atuação das bolsistas não seria no sentido de reforço pedagógico e tratamento clínico das crianças "com problemas" (sic) e as propostas implicavam na alteração de práticas pedagógicas tradicionais, pediram o encerramento da atividade.

Verificamos em vários momentos, a imobilidade dessas professoras em ousarem a criar. O temor de perder "o lugar" de professora impediu a reflexão a respeito de sua prática pedagógica cristalizada. Entendemos as dificuldades de atuação frente à singularidade dos modos de apropriação dos conteúdos escolares de seus alunos. Porém, o maior entrave está no estereótipo de aluno ideal, presente nos discursos e que se concretiza em suas relações cotidianas. O fenômeno do fracasso escolar, as profecias autorealizadoras, tão exaustivamente debatidas por Patto (1993) e Collares (1994) entre outros, ainda não estão superadas, nem está superada, apesar de todos os nossos esforços, a representação do

(...) lugar ideológico ocupado pela Psicologia como mais um agente de exclusão social e de alienação (...) (Valore, 1999, p.121).

Os estereótipos e preconceitos dos professores, quanto aos alunos e suas famílias, corporificam as práticas pedagógicas e as relações de poder disciplinar exercidas. Como afirma Miranda (1995, p.134),

(...) a socialização na escola é qualitativamente distinta, pois nela a criança passa a internalizar novos conteúdos, padrões de comportamento e valores sociais.

Muitas vezes, porém a escola nega os conteúdos e valores já internalizados pela criança ao impor novos padrões de comportamento e valores. Para a mesma autora, a escola tem três tarefas básicas a desempenhar:

Primeiramente, deverá facilitar a apropriação e a valorização das características socioculturais próprias da comunidade onde está inserida. Em segundo lugar, e como consequência da primeira, a escola deverá garantir a aprendizagem de certos conteúdos essenciais da chamada cultura básica (leitura, escrita, operações matemáticas, noções fundamentais de história, geografia, ciências, etc.) Finalmente, deverá propor a síntese entre os passos anteriores, possibilitando a crítica dos conteúdos ideológicos propostos pela cultura dominante (Miranda, 1995, p.133).

O tratamento homogeneizante da escola, dado às crianças e jovens ignora suas singularidades, tratando-os como indivíduos com uma natureza a priori, favorecendo

(...) a subjetividade mecânica através de cada elemento da comunidade, de cada signo, símbolo, ou regra que a atualiza, revigorando-se enquanto fábrica de socialização padronizada (Rocha, 2000, p.186)

A maneira como a escola está organizada apresenta um conteúdo explícito, o conhecimento técnico e normas de conduta; e um conteúdo implícito, a relação com a autoridade e a desigualdade atribuída ao aluno. (Bock, Furtado e Teixeira, 1993). Por isso é preciso conceber a escola como um espaço onde o saber não é manipulado como objeto neutro, nem os alunos como seres passivos, receptores dos conteúdos repassados, como foi possível constatar nas falas e posturas da maior parte das professoras de pré-escola à quarta série.

\section{Considerações provisórias}

As ações desenvolvidas pelo PAESCE tomaram como tema norteador à promoção de saúde, adotando a abordagem institucionalista, promovendo questionamento da lógica instituída, na busca de criar novos territórios para a expressão das subjetividades. Isto porque, compreendemos a escola como palco de conflitos, de relações de poder. É também, cenário de possibilidades de atuação criativa e assertiva de seus membros, marcado pela imprevisibilidade e configurando-se singularmente, provisoriamente, nos oportunizando assim, interceder no cotidiano da instituição.

Durante estes três anos e meio de atuação na escola, construímos uma relação de respeito e diálogo com os profissionais e alunos da instituição. Sentimos sempre o recomeçar, apresentando o projeto e as ações para as três diretoras que neste tempo atuaram na escola, como no início de cada ano letivo, com as trocas de professores. Em fevereiro de 2003 haverá nova direção e novos professores, o que nos move para uma reavaliação 
constante e a busca de outros caminhos para a práxis. E preciso registrar o empenho e parceria que a última diretora conquistou. Compreendeu e acreditou em nosso trabalho, abrindo espaço de discussão com os professores mensalmente, o que antes parecia impossível.

Também nossa equipe de bolsistas já alterou algumas vezes, em função dos compromissos acadêmicos, ou pelo término dos mesmos, ocorrendo o desligamento do vínculo com a Universidade. De um lado perdemos pela afinidade e cumplicidade que estabelecemos, além do conhecimento construído nas discussões teóricas e no cotidiano escolar. Por outro lado, posições e ideias se renovam com a chegada de outros bolsistas.

Acreditamos que um fator gerador das dificuldades dos profissionais da escola, em lidar com os conflitos nos limites da instituição, esteja ligado ao tédio institucional, ao sentimento de que os problemas na escola não têm solução, que é uma luta inútil. Outro fator está ligado aos estereótipos e preconceitos em relação às famílias dos alunos. Estas consideradas hostis e incapazes de acompanhar o desenvolvimento de seus filhos. Boa parte apresenta uma visão determinista, do modelo médico, na busca de patologias, diagnósticos e receitas, desconsiderando as relações e implicações sociais, econômicas, políticas e culturais envolvidas na construção dos sujeitos.

Conhecemos alunos que vivenciaram um processo de ensino aprendizagem de pouca qualidade. A falta de motivação destes em relação a seu aprendizado e as dificuldades cotidianas, somadas ao estigma que se forma sobre estes, transformam o processo educativo numa tarefa pesada e lenta. Estes alunos não sofrem de desvios mentais ou transtornos de conduta. Respondem na defensiva ao modo como são tratados, devolvendo aos professores e colegas as relações autoritárias dos quais são "(...) condicionados, mas não determinados" (Freire, 2002, p.21). ${ }^{16}$ Nossa posição implica em reconhecer que não existem causas individuais para os fenômenos humanos, pois estão engendrados e viabilizados na rede de relações. Portanto,

Existem pessoas com distúrbios, existem lesões que prejudicam o processo ensino-aprendizagem, existe pobreza, existem problemas emocionais, familiares, pais alcoólatras, professores percebendo

\footnotetext{
${ }^{16}$ Grifos do autor.
}

problemas individuais na criança. Existem crianças que merecem atendimento psicoterápico, pois estão sofrendo e paralisadas. Mas não é possível estabelecermos uma relação direta de causa e efeito entre essas questões e a capacidade de aprender (Machado, 2000, p.146).

No decorrer dos encontros com os professores apareceram, repetidamente, o discurso da culpabilização da família, e seu desejo de terem uma fórmula pronta para a resolução dos conflitos em sala de aula, marcados pela verticalidade, na postura tradicional das práticas pedagógicas. Como proposta para o ano de 2003, estamos discutindo o estreitamento dos laços com essas famílias. Queremos ouvir o que pensam sobre a educação de seus filhos e esta escola e quem sabe, propiciar um vínculo de parceria nas ações educativas.

Nossa permanência na Instituição se revestiu de momentos gratificantes, mas também, de frustrações e necessidades de reavaliações constantes de nosso fazer e saber. As dificuldades e resistências nos levam a buscar caminhos e leituras que nos possibilitem ir além da compreensão dos fenômenos, ou seja, na intercessão da micropolítica da instituição, buscando criar um outro tempo/espaço.

As concepções epistemológicas que permeiam as práticas da escola e suas diferenças com o trabalho proposto pela equipe de extensão estiveram presentes, nas discussões e embates de nosso cotidiano. Compreendendo melhor a diversidade de opiniões e expectativas envolvendo o projeto, nas demandas da escola, passamos a entender nossas dificuldades na efetivação de algumas atividades. Concordando com Veronese (2001), a posição caracterizada pelo tensionamento produtivo entre diferentes saberes pode abrir espaços de mediação para a emancipação de sujeitos éticos, ficando clara a necessidade de evitarmos o "epistemicídio" (Santos, 1989). Acreditamos na importância da continuidade dos trabalhos, em busca de uma postura mais crítica, reflexiva e criativa tanto dos agentes institucionais, como de nossa equipe, frente às diferenças, desafios e possibilidades da efetuação de um trabalho interdisciplinar para a promoção de saúde.

\section{Referências}

Andaló, C.S. (1995). Fala Professora! Repensando o aperfeiçoamento docente. Petrópolis, RJ: Vozes. 
Bock, A.M.B.; Furtado, O. e Teixeira, M.L.T. (1993). Psicologias: uma introdução ao estudo da psicologia. $5^{\text {a }}$ ed. São Paulo: Saraiva.

Brasil. Secretaria de Educação Fundamental. (1997). Parâmetros curriculares nacionais. Brasília: MEC/SEF.

Collares, C.AL. (1994). O cotidiano escolar organizado. Campinas, Tese (Livre-Docência) - FEUNICAMP.

Fontoura, L. V.; Galvan, S. e Didoné, J. (2001). Atenção à educação e saúde na comunidade escolar. Alcance. Ano VIII, n. 2, Itajaí: UNIVALI, maio, p.3338.

Foucault, M. (1995). Microfísica do poder. $11^{\text {a }}$ Reimpressão. Rio de Janeiro: Graal.

Freire, P.(2002). Pedagogia da autonomia: saberes necessários à prática educativa. São Paulo: Paz e Terra.

Heller, A (1992). O cotidiano e a história. $3^{\text {a }}$ ed. Rio de Janeiro: Paz e Terra.

Laterman, I. (2000). Violência e incivilidade na escola: nem vítimas, nem culpados. Florianópolis: Letras Contemporâneas.

Machado, AM. (2000). Avaliação psicológica na educação: mudanças necessárias. In: Tanamachi, E. R.; Rocha, M.L. e Proença, M. (org.). Psicologia e educação: desafios teórico-práticos. São Paulo: Casa do Psicólogo, p.143167.

Martinez, A. M. (1996). A escola: um espaço de promoção de saúde. Psicologia Educacional, 1, n.1, 19-24.

Miranda, M. G. O processo de socialização na escola: a evolução da condição social da criança. In: Lane, S.T.M. e Codo, W. Psicologia Social: o homem em movimento. São Paulo: Brasiliense, 1995.

Parto, M.H.S. (1984). Psicologia e Ideologia: uma introdução crítica à psicologia escolar. São Paulo: T A. Queiroz.

. (org.). (1997). Introdução à psicologia escolar. $2^{\mathrm{a}}$ ed. São Paulo: TA. Queiroz.
(1993). A produção do fracasso escolar: histórias de submissão e rebeldia. São Paulo: TA. Queiroz.

Petitati, A. (1994). Produção da escola/produção da sociedade. Porto Alegre: Artes Médicas.

Rocha, M.L. (2000). Educação em tempos de tédio: um desafio à micropolítica. In: Tanamachi, E. R.; Rocha, M.L. e Proença, M. (org.). Psicologia e educação: desafios teórico-práticos. São Paulo: Casa do Psicólogo, p.185-207.

Santos, SV. (1989). Pela mão de Alice: o social e o político na pósmodernidade. São Paulo: Cortez.

Sawaia, B.B. (1994). Cidadania, diversidade e comunidade: uma reflexão psicossocial. In: Spink, M.J. (org.). A cidadania em construção: uma reflexão transdisciplinar. São Paulo: Cortez, p.147-156.

Severino, A. J. (1991). A formação profissional do educador: pressupostos filosóficos e implicações curriculares. ANDE. Ano 10 n.17, São Paulo: Cortez, p.29-40.

Tanamachi, E. R.; Rocha, M.L. e Proença, M. (org.). (2000). Psicologia e educação: desafios teórico-práticos. São Paulo: Casa do Psicólogo.

Valore, L.A. (1999). Contribuições da psicologia institucional ao exercício da autonomia na escola. In: Silveira, A. F. et. AI. (orgs.). Cidadania e participação social. Porto Alegre: ABRAPSOSUL, p.119-128.

Veronese, MV. (2001). Práticas institucionais. In: Rivero, N.E.E. (org.). Psicologia Social: estratégias políticas e implicações. Santa Maria: ABRAPSOSUL, 2001, p.141-150. 


\section{PSICOLOGIA, SAÚDE E TRABALHO}

\section{Capacitação em saúde mental com técnicos do Programa Saúde da Família do município de Forquilhinha}

Dipaula Minotto da Silva ${ }^{1}$ Eliziane Martins Bernardo ${ }^{2}$ Edelu Kawahala ${ }^{3}$

A iniciativa quanto à realização do trabalho de "Capacitação com os Técnicos do Programa Saúde da Família (PSF) do município de Forquilhinha", ocorreu a partir de uma solicitação do município que demonstrou a necessidade de um trabalho voltado às equipes de saúde para facilitar um olhar mais abrangente em torno da saúde mental, em conformidade com os princípios do PSF, onde fica de responsabilidade dos municípios "garantir educação permanente para os profissionais envolvidos" (Ministério da Saúde, 1991). Logo, busca proporcionar um ambiente onde se possa perceber o ser humano como um cidadão capaz, com autonomia, responsabilidade, liberdade e mostrando que a promoção de saúde mental depende também de profissionais que percebam que uma pessoa constitui-se nas relações sociais e culturais, além de sua realidade socioeconômica.

Houve interesse em iniciar o Estágio Supervisionado em Psicologia Social Comunitária, realizando um trabalho onde é possível estar colaborando para as transformações positivas que vem ocorrendo no que diz respeito à saúde mental, numa perspectiva antimanicomial. Iniciou-se então o projeto "Capacitação em Saúde Mental com Técnicos do Programa Saúde da Família do Município de Forquilhinha" com objetivo de criar multiplicadores em saúde mental.

\footnotetext{
${ }^{1}$ Acadêmica do curso de Psicologia da Universidade do Extremo Sul Catarinense - UNESC. ${ }^{2}$ Acadêmica do curso de Psicologia da Universidade do Extremo Sul Catarinense - UNESC. ${ }^{3}$ Prof $^{\mathrm{a}}$ do departamento de Psicologia da Universidade do Extremo Sul Catarinense UNEC, Mestre pela UFSC.
}

Dentro dos princípios do SUS nasce o Programa Saúde da Família (PSF), uma estratégia que prioriza as ações de promoção, proteção e recuperação da saúde dos indivíduos e da família, do recém nascido ao idoso, de forma integral e contínua. O objetivo do PSF é de reorganização da prática assistencial em novas bases e critérios, em substituição ao modelo tradicional de assistência orientado para a cura de doenças e no hospital. A atenção está centrada na família, entendida e percebida a partir do seu ambiente físico e social, o que possibilita às equipes uma compreensão ampliada do processo saúde/doença e da necessidade de intervenções que vão além de práticas curativas.

Com base nestas mesmas diretrizes, a assistência à Saúde Mental vem sofrendo importantes transformações a partir da Reforma Psiquiátrica brasileira. Esta reforma tem por base a desinstitucionalização que compreende a descentralização hospitalar através da criação de serviços assistenciais diferenciados.

Esta tendência nas últimas décadas de modificar, em diversas partes do mundo, a natureza da Assistência Psiquiátrica, tentando deslocar o centro do atendimento ao usuário do Hospital Psiquiátrico para serviços localizados no seio da comunidade e em íntima relação com as mesmas, levou muitos países e localidades a realizarem planos, projetos e programas na busca deste novo modelo. Isto no sentido de proporcionar aos usuários um tratamento mais digno. Há hoje em nosso país uma série de referencias destes serviços. Aproximadamente 20 estados possuem Centro de Atenção Psicossocial (CAPS), que funcionam com atividades terapêuticas e equipe multiprofissional, atendendo cinco dias por semana. Além destes, outros serviços são oferecidos, tais como Núcleo de Atenção Psicossocial (NAPS), semelhante ao CAPS, porém com atendimento sete dias por semana 24 horas, o Hospital Dia/Hospital Noite que é um recurso assistencial intermediário entre a internação e o ambulatório, leitos psiquiátricos em Hospital Geral para quando esgotadas as possibilidades de assistências em outras unidades e serviço Residencial Terapêutico que prevê alocação de recursos e cuidados aos usuários cronificados que vivem nos Hospitais Psiquiátricos sem referencias familiares.

Partindo portanto do princípio de que o PSF, o SUS e a Reforma Psiquiátrica tem princípios semelhantes de descentralização, de promoção de saúde, de integração dos profissionais da saúde com a comunidade e, 
percebendo que os mesmos vêm procurando dignificar os sistemas de atendimento aos usuários, este trabalho de "Capacitação em Saúde Mental com Técnicos do Programa Saúde da Família do Município de Forquilhinha", facilita um olhar diferenciado a respeito de saúde mental aos profissionais que fazem parte das equipes do PSF em Forquilhinha.

\section{Marco teórico}

Como base teórica de nosso trabalho, tratando da produção social da "loucura", parte-se das ideias dos autores Erving Goffman, Michel Foucault e Thomas Szasz, percebendo que a "doença mental" é produzida nas relações sociais que os indivíduos mantém em seu convívio. E nestas relações que os indivíduos vão se constituir enquanto ser, integrados num sistema de valores, de crenças, sistema econômico, social e cultural.

Cada pessoa se constitui de maneira diferente, produzindo e reproduzindo aquilo que vivência. Ao se deparar com o diferente acaba-se por excluir ao invés de dignificar, aceitar ou compreender o indivíduo como um todo, percebendo o seu processo de vida e suas relações sociais.

A ênfase dada à "doença mental" através da razão e desrazão da loucura de acordo com a moral (Foucault, 1984) é um dos pontos centrais do processo de exclusão. A loucura é um julgamento moral do outro e ligada também à questão do trabalho. Marginais, prostitutas, loucos, doentes mentais, quem não trabalha são reclusos nos hospícios. Julgamento este feito por autoridades que possuem o poder de determinar quem é "louco" ou não.

A internação psiquiátrica gera consequências muitas vezes irreparáveis nestes indivíduos excluídos, principalmente dificultando sua reintegração com o mundo externo. Após as humilhações sofridas, falta de contato com seus pertences pessoais e com a família, sua integridade e sua identidade poderão estar comprometidas. Esta é a critica feita às instituições totais quanto aos tipos de relações que se estabelece dentro destas, provocando o processo de despersonalização de eu (Goffman 1974).

Quando nos dizem que se um paciente psiquiátrico que chega cedo para consulta está angustiado, se chega tarde é hostil e se chega na hora é compulsivo - rimos, porque se supõe que isso seja uma piada. Mas nesse caso ouvimos a mesma coisa, dita com toda a seriedade (Szasz, 1984).

Em relação à psiquiatria institucional, a questão do poder, do excluir e da punição, a comparação entre e psiquiatria institucional e à Inquisição feita por Thomas Szasz, norteia a questão do domínio de poder e da exclusão social existentes em épocas diferentes.

$\mathrm{O}$ poder e a riqueza dos psiquiatras aumentam com a crescente incidência de doença mental, e embora a feitiçaria era tida como um problema teológico, a identificação das bruxas poderia ser feita tanto por teólogos profissionais, como por caçadores de bruxas. Assim também a doença mental pode ser diagnosticada tanto por médicos psiquiatras quanto por não médicos, psicólogos e assistentes sociais (Szasz,1984).

A internação desencadeia um ponto decisivo na vida e na história do desatino, momento em que a loucura é verificada no âmbito social da pobreza, da falta de capacidade para o trabalho na impossibilidade de integrar-se no grupo (Foucault, 1984). Há necessidade de retirar da sociedade aquilo que a incomoda. Criam-se então instituições para abrigar estas pessoas isolando-as da sociedade. Pobres e pessoas marginalizadas ou que não possuem comportamento desejado pela maioria na época, eram retiradas da sociedade. Porém estas atitudes ainda existem apesar de todos os esforços que vem sendo feitos.

Partindo destes ideais e tendo conhecimento das práticas que vem sendo realizadas no que tange à saúde mental e suas transformações, faz-se uma crítica ao modelo puramente assistencialista, ou seja, aos modelos institucionais.

Os manicômios ou Hospitais Psiquiátricos, além de assistencialistas, mostram um atendimento longe de ser digno ou de respeito para com o interno, tolhe sua liberdade de expressão e de pensar, seus sentimentos são "podados" assim como as relações sociais. Não há respeito para com a subjetividade dos indivíduos e o processo de busca é limitado pelos muros, cadeados, tratamento inadequado e a indiferença de uma equipe sem preparo, muitas vezes também cronificada pelo sistema. Trancar não é tratar.

Essa cronificação atinge não apenas as instituições totais. Muitos dos profissionais que hoje trabalham com saúde mental em programas de saúde 
pública vem de experiências em manicômios. Com isso pode-se dizer que existe além dos muros e grades, uma cultura de tratamento "manicomial".

A noção de desinstitucionalização é uma importante referência no projeto de reforma psiquiátrica.

A institucionalização passa a ser percebida como um novo problema, como algo a impor novos sofrimentos e alienação e não como solução terapêutica para a enfermidade mental (Amarante, 1995).

Neste sentido, como processo desta discussão surge no Brasil, o Movimento de Luta Antimanicomial na busca do respeito aos direitos humanos, entendendo-se que até então não era percebido no modelo de psiquiatria institucional.

Partindo deste princípio, o Movimento de Luta Antimanicomial busca através de articulação política, concretizar a dignificação dos sistemas de atendimento aos indivíduos. Técnicos envolvidos com a causa, pessoas que tiveram experiências em hospitais psiquiátricos/manicômios, familiares destes e pessoas sensibilizadas, integram este Movimento de luta contra um processo agressivo de "cura".

No caminho do processo de desinstitucionalização e da Reforma Psiquiátrica, vem surgindo uma crescente necessidade, de que trabalhos voltados à promoção de saúde mental na comunidade sejam realizados. E mais, que estes sejam realizados a partir de um ideal de transformação para um sistema que passe a valorizar a saúde integral do indivíduo, uma vez que é a partir das relações sociais, da realidade socioeconômica, das condições de moradia, enfim, do seu contexto, que o sujeito vai se constituir.

Percebe-se que estes trabalhos voltados à saúde mental na comunidade devem estar ligados a uma rede articulada, ou seja, todos os setores relacionados à saúde devem estabelecer uma rede de comunicação, de maneira que o individuo possa transitar por estes setores, conforme suas necessidades, sendo respeitada sua individualidade e sua identidade, fazendo valer seus direitos de cidadão.

A equipe de PSF, essencial para a realização dos trabalhos, é percebida como peça chave para que mudanças e atitudes geradoras de saúde mental sejam concretizadas.
O desafio está posto. Redimensionar um modelo de atenção à saúde, de forma que ele esteja em sintonia, com as novas concepções de saúde defendidas pelo SUS, requer constante movimento de reflexão embutido na práxis. Mudanças de concepções não acontecem facilmente e o ponto de partida, somos nós mesmos, profissionais de saúde. Só assim poderemos nos lançar com firmeza nesse objetivo de construir uma rede de saúde integrada e inovadora (Cabral et al in Lancetti. 2000).

Visto que a produção da "loucura" se dá no meio social, e que as Agentes Comunitárias de Saúde do PSF convivem com a comunidade através de visitas mensais, percebe-se este programa como um veículo para realização deste trabalho com a equipe de saúde. Iniciar-se-á com este, maior possibilidade de comunicações com os sistemas de saúde mental, pois a equipe estará capacitada para interagir de forma coerente com estes sistemas. A partir destes, os processos de exclusão por parte da equipe e consequentemente por parte da comunidade estarão aos poucos deixando de existir.

\section{Procedimentos metodológicos}

No estágio em psicologia social comunitária, realizou-se encontros com os técnicos na unidade de PSF, visitas domiciliares junto as agentes comunitárias de saúde, participação no projeto ação comunitária realizado pela equipe na comunidade e capacitação direcionada aos médicos do município.

\section{Encontros com os técnicos na unidade de PSF}

Realizou-se um total de 17 (dezessete) encontros semanais nas quartas-feiras no período vespertino. Nestes encontros ocorreram vivências, dinâmicas e debates em grupos, nos quais se propôs os temas: integração da equipe, concepção saúde/doença mental, conceito/preconceitos, rótulos, relação técnico-usuário e percepção do usuário como um indivíduo apropriado de sua história e pleno de cidadania. As dinâmicas e vivências foram escolhidas de acordo com os temas e a necessidade da equipe de $\mathrm{PSF}$, procurando reconhecer a realidade da mesma no decorrer dos encontros. 
Durante estes encontros o posto permaneceu fechado para o público externo e os técnicos estavam à disposição do projeto, por determinação da Secretaria de Saúde do Município.

\section{Visitas domiciliares junto aos Agentes Comunitárias de Saúde}

Nas sextas-feiras pela manhã, caminhou-se pela comunidade no sentido de conhecer a mesma, os casos mais citados nos encontros semanais com os técnicos e estar percebendo o quotidiano das Agentes Comunitárias de Saúde. Estas visitas tiveram grande importância pois facilitaram uma melhor visualização da realidade da comunidade atingida pelo PSF, enriquecendo as vivências e discussões.

\section{Participação no Projeto Ação Comunitária realizada pela equipe na} comunidade

Após o início da discussão sobre conceito e promoção de saúde, as agentes comunitárias sentiram-se motivadas a realizarem o dia da Promoção de Saúde, com o projeto "Ação Comunitária". Neste, houve atividades de recreação, barracas de exposições e a realização de palestra sobre Prevenção de doenças, integração dos Missionários Mirins, palestra com Conselheira Tutelar, palestra sobre alcoolismo e havia inicialmente a ideia de uma palestra na área de psicologia. Ao invés desta, realizou-se uma vivência de Terapia Comunitária ${ }^{4}$ com os presentes no evento, em média de vinte e cinco pessoas. O objetivo desta é proporcionar um espaço para melhorar a qualidade de vida da comunidade, onde o grupo traz suas dificuldades.

\section{Capacitação direcionada aos médicos do município}

Em conformidade com a Secretaria de Saúde do Município nas primeiras reuniões, percebeu-se a necessidade de estar integrando os médicos do município nesta capacitação. Para tanto foi convidado o Médico Psiquiatra Dr. Rui Martins Iwersen, ${ }^{5}$, psiquiatra do Programa de Saúde Mental, que atua no NAPS Ponto do Coral e no Programa DST/AIDS do Município de Florianópolis, a estar durante um dia (manhã e tarde) com

\footnotetext{
${ }^{4}$ Vivência trazida à Unesc no curso de Terapia Comunitária, pelo médico psiquiatra Dr. Adalberto Barreto.
}

${ }^{5}$ Doutorando em etnopsiquiatria, pela Universidade de Paris. médicos e enfermeiras das seis equipes do PSF, psicólogas e a assistente social do município.

\section{Relação teórica-prática e resultados obtidos}

No que diz respeito à saúde mental como o problema da exclusão, da produção social da loucura, preconceitos e rótulos, trabalhou-se com a equipe do Programa Saúde da Família (PSF) de Forquilhinha, com o objetivo de promover a saúde integral por meio de multiplicadores e atuando na comunidade.

Há de se retomar o sonho de uma nação saudável. Acreditar que é possível retomar o crescimento, superando as desigualdades sociais, assegurar a construção da democracia (...) que

somente se corporifica no ambiente democrático, onde se encontram a emergência de novos sujeitos políticos, a liberdade do discenso e o governo dos cidadãos (Mendes, 1993 p.42)

Dessa forma foram levantadas questões sobre saúde mental, bem como as diferentes visões do cuidado e do cuidador e da visão do usuário de saúde mental como ser pleno de autonomia e pleno de cidadania.

Trabalhou-se com o grupo de forma vivencial, onde foi propiciada a integração grupal de forma que os técnicos hoje formam uma equipe coesa. A concepção de saúde/doença mental também foi trabalhada de forma vivencial.

No PSF dá-se prioridade a promoção e a prevenção da saúde. Nesse trabalho de capacitação, discutiu-se a saúde integral, enfatizando a saúde mental. Porém nos encontros realizados percebeu-se que, mesmo com os princípios do PSF de promoção e prevenção a saúde, ainda apareceu associada ou comparada com a doença. Essa discussão se ampliou ao nível do normal e do patológico.

(...) o grupo parte da análise de situações quotidianas para chegar à compreensão das pautas sociais internalizadas que organizam as formas concretas de interação, ou seja, das relações sociais e dos sujeitos inseridos nessas relações (Lane, 1984).

De maneira simples e abrangente o grupo colocou como fatores geradores de saúde: questões de higiene, habitação, meio ambiente, 
questões emocionais, familiares, questões das relações sociais e econômicas e a prevenção (o grupo exemplificou esta última com as campanhas de vacinação).

No decorrer dos encontros percebeu-se que o grupo estava em processo de crescimento coletivo. Quando trabalhado a questão dos rótulos, obteve-se de forma clara a dificuldade de lidar com a inclusão e a cidadania. Apresentaram-se os preconceitos do grupo e a exclusão social.

Discutiram-se então os processos de formação do ser humano, enquanto ser social e de relações. Promoveram-se reflexões a respeito da inclusão social, dos processos que ocorrem na formação do eu do usuário e a importância da inclusão, do respeito, da aceitação, da empatia e como estas atitudes influenciam e contribuem no processo de inclusão social do egresso de hospital psiquiátrico.

Debateu-se sobre possíveis visitas à Casa de Saúde do Rio Maina de Criciúma e ao NAPS de Florianópolis, uma vez que, nas discussões a respeito dos modelos de atendimento em saúde mental, a equipe relatou o interesse de ter contato direto com estes sistemas.

Reflexões referentes à caridade foram feitas percebendo uma prejudicial comparação com a questão do cuidar, retomando a importância da inclusão. Cuidar é também potencializar as ações do outro despertando sua autonomia.

A partir destas discussões, a equipe passa a perceber que o usuário deixa de ser o paciente institucionalizado, tornando-se o ator e autor da sua própria existência, um cidadão com suas capacidades, habilidades e potencialidades.

\section{Considerações finais}

No decorre de todo esse processo observou-se uma grande abertura no município de Forquilhinha para a realização deste trabalho. A necessidade de se iniciar uma estrutura sólida, no que tange a saúde mental no município e articular o atendimento nesta área de forma local e em interação com a comunidade, levou a conclusão do trabalho de "Capacitação em Saúde Mental com Técnicos do Programa Saúde da Família (PSF) do Município de Forquilhinha”, em uma destas unidades.
Desta forma observou-se ser de total importância trabalhar a equipe técnica com o objetivo de gerar multiplicadores em saúde mental. No que tange o olhar, propiciou-se uma nova visão sobre os cuidados, trabalhando os rótulos e os preconceitos, interagindo num sistema de valores e ressignificando alguns, conhecendo ou desmistificando a chamada "loucura".

Observou-se também, a importâncias das atitudes que estão procurando formalizar uma rede articulada de saúde mental, partindo do próprio grupo, que apresentou interesse em ter um serviço de atendimento em saúde mental como um Centro de Atenção Psicossocial (CAPS). Concluindo ser essencial a visão de um tratamento especializado e descentralizado, interagindo de forma direta com as famílias e com a comunidade.

Nesta equipe, após o trabalho de capacitação, começou-se a ver o usuário de saúde mental, como ser mais integrado na sociedade, estabelecendo relações, constituindo e reconstituindo-se a todo o momento, desenvolvendo sua autonomia e cidadania.

A extrema relevância no tratamento destes usuários de saúde mental, a inclusão social, e o acompanhamento de toda uma equipe multiprofissional são de grande valor para desmistificação e dignificação do atendimento aos usuários. Portanto, a importância de se atingir o maior número de técnicos possíveis, que por sua vez, atingirão várias outras pessoas em suas relações profissionais, concretizarão a formação de multiplicadores. A capacitação das equipes de PSF (médicos, enfermeiros, auxiliares de enfermagem e agentes comunitárias de saúde), equipe que está ligada diretamente à comunidade, bem como de outros os profissionais da saúde (assistentes sociais, psicólogos, entre outros) vão proporcionar o diferencial na concretização da dignificação no atendimento aos usuários.

Forquilhinha, que não possui um atendimento referencial próprio em saúde mental, demonstra o interesse, para que a capacitação com os técnicos do PSF seja realizada. Porém, após a conclusão desta etapa percebeu-se também a necessidade de um trabalho realizado com a equipe de profissionais do município que não fazem parte das equipes do PSF e continuidade do trabalho nas outras equipes de PSF. 


\section{Referências}

Amarante, Paulo (1995) Loucos Pela Vida: A trajetória da Reforma Psiquiátrica no Brasil. RJ. SDE/ENSP, 1995.

Foucault, Michael (1997) A História da Loucura na Idade Clássica. $5^{\mathrm{a}}$ ed. SP. Perspectiva. Brasileiro.

Freire, Paulo (2002) Pedagogia do Oprimido. 32 ed. SP. Paz e Terra.

Goffman, Erving (1988) Estigma. $4^{\mathrm{a}}$ ed. Guanabara Roogan.

. (1996) Manicômios, prisões e conventos. $5^{\mathrm{a}} \mathrm{ed}$. SP. Perspectiva.

http://www.saude.gov.br/programas/pacs/psf.htm

Lancetti, Antônio (1984) Saúde Loucura: Saúde Mental e Saúde da Família. SP. Hucitec.

Lane, Silvia, T. M. et al. 1984) Psicologia Social o homem em movimento. São Paulo: Brasiliense.

Szasz, Thomas (1984) A fabricação da Loucura um estudo comparativo entre a inquisição e o movimento de saúde mental, $3^{\mathrm{a}}$ ed. Rio de Janeiro: Ed. Guanabara.

\section{Demandas e ofertas da psicologia do trabalho hoje}

Denise Macedo Ziliotto

Há momentos em que a ruptura representa a necessidade de continuar. É nessa perspectiva que este texto é produzido: a trajetória apresentada pelo campo da Psicologia do Trabalho pode e merece sofrer descontinuidades. Com surgimento assegurado por toda uma prática funcionalista digna do apogeu do período industrial, berço da sociedade de consumo, não deve ser este lugar tido como um destino. A proposição de um conhecimento científico ancorado em testes psicométricos e definição de perfis psicológicos seduz uma sociedade ávida por homens certos nos lugares certos. Numa época de exaltação da dita excelência humana, a verdade ofertada - do desvelamento da psique humana - amplia os espaços já concedidos à psicologia escolar e clínica.

Contudo, este envolvimento não se dá sem efeitos. No comprometimento com a eficácia surgem imperativos insistentes, como o equacionamento da fadiga, da indisciplina, da improdutividade, da insubordinação. $\mathrm{E}$ as respostas também são persistentes: testagens, treinamentos, técnicas de gerenciamento de pessoal. As denominações que esta prática recebe traduzem as mudanças sociais: psicologia industrial, psicologia organizacional, psicologia do trabalho. E o avanço de um repertório científico que se estende sobre as diversas formas de organização social destinada à produção. As incompatibilidades do sujeito trabalhador com o 'tratamento' oferecido pelos psicólogos são expressas e reiteradas no fracasso de muitas intervenções. Nesta confissão de dívida - com o campo psicológico e com os sujeitos que a ele recorrem — propomos uma revisão das possibilidades e das limitações da psicologia praticada sob as denominações do trabalho ou organizacional hoje, fazendo proposições que visam a escritura de uma história mais coerente e ética.

Japiassu (1983) assinala a importância desta postura:

Creio que precisam ser revistos os métodos de se fazer psicologia e de ensiná-la. Creio também que tais métodos deveriam ser orientados para a preparação de inovadores nas pesquisas psicológicas, e não

${ }^{1}$ Psicóloga e Jornalista. Doutoranda em Psicologia Social pela USP. Docente universitária. 
para o lançamento no mercado de trabalho de técnicos manipuladores do comportamento humano, espíritos conformistas e submissos a inércia das situações adquiridas. Para tanto, não vejo como a psicologia possa realmente retomar seu vigor e readquirir uma real fecundidade excluindo de seu campo de investigação a subjetividade do homem, a não ser que persista em tratá-lo como mera exterioridade, cientificamente analisada, mas sem nada poder dizer sobre a realidade humana (Japiassu, 1983, p.154)

\section{Ofícios e lugares}

A ampliação oferecida ao espaço "psi" no setor empresarial, desde o início do século XX, é análoga ao movimento social que idealiza e busca normatizações no comportamento humano. As ciências promoveram uma verdadeira ode à verdade, ao positivismo e à naturalização da cultura. Em busca de um ser humano adaptado às exigências ditadas por estes valores, a Psicologia contribui com técnicas e postulações científicas, corroborando o funcionamento social vigente:

A profissão do psicólogo esteve inicialmente ligada aos problemas de educação e trabalho. O psicólogo "aplicava testes"; para selecionar o "funcionário certo" para o "lugar certo", para classificar o escolar numa turma que lhe fosse adequada, para treinar o operário, para programar a aprendizagem, etc. Todas essas funções ainda são importantes na definição da identidade profissional do psicólogo e mostram claramente como até hoje a vinculação das psicologias às demandas do Regime Disciplinar são importantes (Figueiredo \& Santi, 2000, p.85).

A denominação "RH" que setoriza o lugar habitualmente ocupado pela Psicologia nas organizações ilustra com clareza a posição adotada. Se trata o indivíduo enquanto recurso e não enquanto sujeito, acaba por engendrá-lo dentro da ótica empresarial, negando as questões que pautam os pressupostos das ciências humanas. Testar, desenvolver e treinar ações características da Psicologia neste campo — são ações que implicam relação díspar de conhecimento e poder. Podem ser aplicadas a objetos, ou mesmo "coisificar" mediante o estabelecimento do processo.

A suspeita de que a liberdade e a singularidade dos indivíduos são ilusórias, que emerge com o declínio das crenças liberais e românticas, abre espaço, finalmente, para os projetos de previsão e controle científicos do comportamento individual. Este será um dos principais objetivos da psicologia como ciência, a serviço das Disciplinas. (Figueiredo \& Santi, 2000, p.51)

A questão decorrente desta prática é o afastamento (compreensível) dos sujeitos desta Psicologia, fruto do descrédito e da desilusão para com seus postulados. Não havendo crédito e, por consequência, comprometimento, o que se observa é um esvaziamento progressivo insistente dos efeitos das intervenções psicológicas nas organizações:

legitimou-se o descrédito da palavra dos sujeitos do trabalho pela organização do trabalho, organização esta que planeja e executa sem minimamente considerar as interferências impostas em sua vida, causando assim o sofrimento individual e o adoecimento coletivo da classe trabalhadora. (Grisci \& Lazarotto, 1998, p.231-2)

Entretanto, decorrem modificações nos lugares "psi" ainda mais lamentáveis. O setor empresarial restringe significativamente os postos destinados a profissionais psicólogos, encontrando em administradores e outros técnicos a substituição mais adequada para prosseguir oferecendo eficácia ao gerenciamento de pessoal. Cresce o DP - Departamento de Pessoal - enquanto órgão normativo das políticas de pessoal e diminui consideravelmente os espaços destinados às atividades com possibilidade de escuta dos trabalhadores. De outro lado, crescem as críticas e as 'indisposições' da classe dos psicólogos com relação aos que se dedicam a este ofício, tornando explícito o descontentamento com a atuação e os rumos da psicologia exercida na área do trabalho.

A perda torna-se maior: vê-se diminuir o espaço para operar nesta realidade e a capacidade crítica, pois a contribuição fica no plano da denúncia, do oposicionismo... Assim, crescem os instrumentos de gestão oferecidos pela perspectiva administrativa, evidenciados, por exemplo, no uso majoritário nos dias atuais(!) das obras de Idalberto Chiavenato (Introdução à Teoria Geral da Administração, Recursos Humanos, Gestão de Pessoas; o Novo Papel dos Recursos Humanos nas Organizações, Treinamento e Desenvolvimento de Recursos Humanos) nos programas de formação de psicólogos. A frequente parceria entre estes profissionais e administradores seja em congressos, publicações e projetos - confirma a proximidade dos campos, ainda que de forma desigual em suas contribuições. Pode-se observar a predominância dos instrumentos e 
postulados da lógica administrativa seja nos gráficos, fluxogramas ou expressões empregadas usualmente pelos psicólogos. O contraponto não aparece na mesma medida: sujeito, identidade, psiquismo não são vocábulos facilmente encontrados nas descrições dos processos de gestão.

Longe dos campos da Sociologia e da Medicina do Trabalho, a Psicologia ressente-se das limitações de seu entendimento acerca da realidade do mundo do trabalho e acaba por encontrar na sedução da lógica funcionalista fundamentos para o exercício de suas atividades. Passa, de alguma forma, a pautar a sua atuação pelas demandas essencialmente advindas do imperativo da produção e abandona os referenciais de seu objeto - o homem no trabalho.

\section{Consequências}

O cenário atual é preocupante. Contudo, na mesma medida, promissor. Esta suposta contradição explica-se pelo estado atual da área: conclama um nome - Psicologia do Trabalho (e o abandono definitivo das denominações Psicologia Organizacional, Industrial, RH, etc.) e uma trajetória renovada por princípios e ideias novas, já que o estreitamento de sua intervenção cresce dia a dia.

A resistência dos alunos graduandos a esta área é flagrante. Vista como "traidora", desviante da verdadeira Psicologia, recebe uma atenção pouco qualificada nos cursos de graduação, remetendo-se comumente a uma disciplina cumprida enquanto obrigatória para a formação, mas destituída de sentido na prática profissional futura. Paralelamente e, para tornar ainda mais "compreensível" a situação, o número de vagas para estágio decresceu consideravelmente, praticamente invertendo a situação outrora/vigente: a demanda está do lado do aluno estagiário, predominantemente. E ele quem vai buscar sensibilizar a empresa a respeito da sua potencialidade e, em última instância, da necessidade de seu aprendizado através da experiência.

Neste âmbito, têm-se assistido a uma diversidade incompreensível de modalidades de estágio curricular em Psicologia Organizacional, onde docentes e universitários facilmente atribuem ao "mercado" os entraves encontrados. Constatada a dificuldade em encontrar locais, dispõe-se práticas alternativas para viabilizar o cumprimento das normativas curriculares: na maioria destas o contato com a realidade empresarial é cada vez menor. Quanto à possibilidade de intervenção, as perspectivas são ainda mais longínquas. Estagiários e organizações pouco dialogam; o reflexo de suas impressões e suas possíveis contribuições fica, na maioria das vezes, na supervisão semanal acadêmica. O supervisor, por sua vez, torna episódico o seu encontro com as instituições, seja pela sobrecarga de trabalho docente, seja porque esta iniciativa não está amparada pelos dispositivos administrativos da universidade onde trabalha.

A pesquisa ainda alcança número pouco expressivo em sua produção e publicação, tendo-se em vista a capacidade e a necessidade demandadas pela situação que se configura. A Economia, a Sociologia e a Medicina do Trabalho têm sido referentes para os psicólogos que tentam superar a inconsistente (e muitas vezes inconsequente) bibliografia existente sobre as relações atinentes ao trabalho, o que é um ganho pela interdisciplinariedade possível, mas manifesta também a inoperância produtiva da área.

Por fim, pode-se também elencar, sem pretender esgotar as dimensões que esta questão abarca, o número ainda tímido de cursos de pós-graduação com ênfase em Psicologia do Trabalho, nos níveis de mestrado e doutorado. A inclusão nos programas de Psicologia Social ou de Administração tem sido a opção encontrada por aqueles que desejam fazer pesquisas e prosseguir estudando neste campo. A indefinição do lugar e da contribuição da Psicologia que se propõe a pensar o mundo do trabalho tem se refletido, como podemos observar, em vários níveis e com repercussões sociais importantes. Como ponto de partida para reinventar esta trajetória, deve-se inicialmente recuperar princípios éticos e paradigmas que possam nortear e singularizar este campo "psi".

\section{Ética e paradigmas}

Como define Japiassu, todo psicólogo, assim como qualquer cientista, "está comprometido com uma posição filosófica ou ideológica". Esta posição, assegura o autor, "tem uma importância fundamental nos problemas estudados pela psicologia" (1983, p.26). Os avanços e retrocessos, as aberturas e as resistências, presentes na história das ciências humanas são testemunhos destas posturas e crenças que sustentam um campo científico, produzindo dissidências e rupturas muitas vezes tidos como descontinuidades. Contudo, a responsabilidade pelo resguardo aos pressupostos, mesmo que em 
sua reinstauração "atualizada" move a reflexão imprescindível à humanidade existente na Psicologia, escopo deste trabalho. Revisitar o caminho percorrido não é o objetivo em si; este consiste somente num meio para poder entender a historicidade negada e a partir deste saber, construir as proposições que responsabilizam pelo seu futuro.

A questão pode ser redimensionada através do reconhecimento de alguns equívocos:

O fracasso da psicologia consiste em ter-se esquecido de que sua palavra é uma palavra libertadora. Ela se trai a si mesma quando se prostitui com os imperativos da sociedade e das instituições, que só a prestigiam e a "amam" na medida em que ela se presta docilmente a um trabalho de sempre mais adaptar e integrar os indivíduos às estruturas vigentes da sociedade e das instituições (Japiassu, 1983, p.30).

Trata-se fundamentalmente de uma escolha e da assunção de seus efeitos: a projeção social facilitada pelo oferecimento de insumos para o incremento de uma razão instrumental vigente ou a busca de um ceticismo producente, que desvela ilusões e ideais, ofertando e dividindo comprometimento. Amparado por um conhecimento supostamente imparcial e soberano pelo reconhecimento e impacto que provoca socialmente, o psicólogo tem podido prescindir do reconhecimento dos efeitos de sua prática e de seus pressupostos, em muitos momentos. Pode-se verificar esta lamentável ocorrência pela frequência com que a mídia busca opiniões dos profissionais "psi" sobre os mais diversos assuntos, que são respondidos com semelhante voracidade e totalitarismo. A negação do possível desconhecimento, da incógnita provocada pelo questionamento, ainda é um desprendimento difícil ao status esperado e ocupado(!) pelos psicólogos. A presença em programas de entrevista e debates vespertinos infelizmente ainda é muito superior do que a presença em instâncias como o legislativo, o executivo e no gerenciamento de órgãos sociais importantes. Talvez seja importante portar mais do que um aparato consultivo, certamente bem recebido em tempos incertos e pouco promissores. Ser reflexivo e propositivo pode alicerçar uma prática mais profícua. Para tanto, a dimensão ética precisa ser recuperada e seu sentido resgatado:

Nem sempre a Psicologia norteou suas práticas no sentido de considerar a ética. No que se refere ao trabalho, a Psicologia contribuiu muito para que o mérito e o fracasso, por exemplo, fossem vistos como características que dissessem respeito única e exclusivamente aos sujeitos individuais (Grisci \& Lazarotto, 1998, p.230).

Repensar as relações existentes no trabalho, desestatizando as posições trabalhador $x$ empresariado, mas tornando-as dinâmicas (como realmente se apresentam) na sua análise crítica, superando a tradicional atuação através de processos, pode recuperar a causa do próprio existir deste campo. Descrever fluxos e procedimentos está mais afeito a áreas como engenharia e administração, que operam sobre o previsível e o controlável. Conhecer a realidade organizacional certamente é muito mais do que manualizar e rotinizar atividades; realizar um diagnóstico organizacional pode ser incoerente com uma postura menos detentora do saber. Pesquisar e escutar — fatos, lugares e relações - certamente pode conduzir a novos fatos; testar "quali" e quantitativamente, ainda que de forma insiste e incansável na busca do resultado fidedigno, muito pouco.

A consistência com que Guareschi coloca a questão ética elucida ainda mais a questão:

ninguém pode se arvorar o predicativo de "ético" a partir de si mesmo, como quer, exatamente, o liberalismo. O pensamento liberal, a partir da definição de ser humano como "indivíduo", centraliza tudo no "eu", no sujeito da proposição. Perdemos a dimensão relacional, e como consequência mistificamos o verdadeiro sentido da ética (Guareschi, 1998, p.56)

Dos Anjos, apud Guareschi (2000, p.50), situa o campo da ética como sendo "uma instância crítica e propositiva sobre o dever ser das relações humanas em vista de nossa plena realização como seres humanos". Desta forma, o psicólogo deve colocar-se no estudo do campo que atua, incluir-se, repensar a si e a sua atuação. Não há como furtar-se da implicação com a realidade na qual exerce sua profissão. A situação do trabalho hoje é também reflexo de um pensar e de um fazer psicologia, que foi exercido através das seleções de pessoal, dos treinamentos, dos manuais produzidos, das dinâmicas de grupo, das integrações promovidas, enfim, da variedade de dispositivos de que a Psicologia valeu-se para legitimar sua contribuição e pertinência. 


\section{Encaminhamentos}

Sendo fidedigno às suas formulações, este texto não pode fazer somente a prática da denúncia. É preciso ser construtivo, criar possibilidades. Afinal, como afirma Guareschi (2000), enquanto dimensão crítica, a ética está sempre incabada, por fazer-se. À medida em que está presente nas relações, sofre modificações contínuas, questionamentos, apresenta contradições.

Ao mesmo tempo deve ser propositiva. Não pode se furtar a colocar exigências e desafios. Mas esses desafios e exigências podem ser reelaborados, redimensionados, refeitos e retomados (p.51).

Trata-se portanto de uma contribuição que pretende ser acompanhada de outras iniciativas que, pelo seu conjunto, possam representar um efetivo esforço e demanda dos psicólogos pelo campo da Psicologia do Trabalho.

Primeiramente, sugere-se a revisão dos programas acadêmicos que tratam desta disciplina, formulando referências e abordagens mais críticas e coerentes com a formação profissional pretendida. Diretrizes e normatizações sobre o estágio em Psicologia Organizacional, desenvolvidas sob a coordenação do Conselho Federal de Psicologia em conjunto às regionais são imprescindíveis para a defesa de um processo sério e comprometido de aprendizagem e inclusão no mercado de trabalho. Um canal permanente de comunicação com as instituições credenciadas para estágio deve ser previsto, de modo a formalizar espaços, instituí-los e monitorar seu acompanhamento.

$\mathrm{O}$ estímulo à pesquisa e à publicação deve ser uma preocupação constante das instituições, das universidades, dos docentes. E a dúvida e o interesse pela realidade que podem fazer o saudável exercício da mudança e da renovação acontecer. O pensar, refletir e o escrever são garantias de mobilidade: o transmitir adiante este percurso é um dever intransferível.

A promoção de eventos interdisciplinares que tenham como objeto o trabalho, assumindo a Psicologia um papel mais ativo e propiciador da discussão é um fórum importante para divulgar ideias e repartir preocupações. Neste momento, mais do que defender a disciplina, a questão que se impõe é enriquecê-la de contribuições, abrindo-se à aprendizagem necessária e compatível à dimensão de seu campo.
Buscar experiências para além do contexto nacional, recuperando paralelamente a dimensão histórica, pode também trazer descobertas importantes e apurar o tempo. É construindo no tempo a história enquanto psicólogos (e não a reproduzindo, infinitamente) que pode-se ter um compasso mais humano entre nosso pensar e viver o trabalho, razão socialmente justificada de nosso existir.

\section{Referências}

Figueiredo, L. e. M \& Santi, P.L.R. (2000). Psicologia, uma (nova) introdução. ( $2^{\mathrm{a}}$ ed.) São Paulo: EDUC.

Guareschi, P. (1998). Ética. In Strey, M.N. et ai (1998). Psicologia social contemporânea ( $2^{\mathrm{a}}$ ed) (pp.49-56). Petrópolis, RJ: Vozes.

(2000). Ética e ideologia. In Guareschi, P. (org). Os construtores da informação: meios de comunicação, ideologia e ética. (pp 47-68). Petrópolis, RJ: Vozes

Grisci, C.L.I. \& Lazzarotto. (1998) Psicologia Social no Trabalho. In Strey, M.N. et al (1998). Psicologia Social Contemporânea (2 $\left.{ }^{\mathrm{a}} \mathrm{ed}\right)$ (pp 230 — 239). Petrópolis, RJ: Vozes

Japiassu, H. (1983). A Psicologia dos Psicólogos. $2^{\mathrm{a}}$ ed. Rio de Janeiro: Imago Editora. 


\section{Programa de sensibilização para a escolha profissional}

Maria Clara de Jonas Bastos 1 Cláudia S. S. dos S. Schiessl ${ }^{2}$ Everton Cordeiro Mazzoleni ${ }^{3}$

O programa vem sendo desenvolvido há 1 ano e meio nas escolas públicas e privadas da microrregião da Foz do Rio Itajaí Açú e conta com a participação de acadêmicos do $8^{\circ}$ período do Curso de Psicologia da UNIVALI - Itajaí - SC, que cumprem a atividade prática da disciplina de Orientação Profissional do referido curso. Este programa surgiu há 4 anos como um compromisso social, nas ações comunitárias da região. De acordo com o público alvo utilizou-se diversas técnicas que vão desde dinâmicas de grupo, estórias em quadrinhos e apresentações com fantoches. Sabe-se que a maioria das crianças e jovens oriundos de escolas públicas têm sua escolha dificultada, este programa poderá ser um facilitador, um despertar para que os alunos desenvolvam ou incentivem as escolas a desenvolverem pesquisas sobre as diversas profissões, visitas às universidades e escolas técnicas, bem como outras ocupações práticas que existem (pedreiro, carpinteiro, vendedor, etc.). Pretende-se também desmistificar que a escolha profissional, para ser adequada, precisa necessariamente passar pela formação universitária. Atualmente, o programa está estruturado em 4 etapas, sendo 2 supervisões técnicas e 2 intervenções nas escolas. Nas escolas trabalha-se a sensibilização para a escolha através de dinâmicas de grupo ou técnicas de psicodrama (de acordo com o perfil da clientela), na última intervenção, a partir do interesse apresentado pelo grupo, realiza-se a informação profissional. Encerra-se com a devolução à direção e/ou orientadora educacional da escola. Embora não haja um único enfoque teórico em Orientação Profissional, dá-se ênfase a dois enfoques: Teoria de Super e de Bohoslavsky. Até o $1^{\circ}$ semestre/2002 atendeu-se 1.194 alunos, podendo-se destacar: maior integração universidade e escola, minimização

${ }^{1}$ Mestre em Psicologia Social e da Personalidade, Psicóloga e Supervisora na Área de Psicologia Organizacional/Trabalho - UNIVALI.

${ }^{2}$ Mestre em Psicologia Social e da Personalidade, Psicóloga da Seção de Processo Seletivo da UNIVALI.

${ }^{3}$ Acadêmico do $9^{\circ}$ Período do Curso de Psicologia — UNIVALI. da ansiedade dos alunos ao propiciar maior acesso às informações sobre o processo de escolha e, também, sobre as profissões e mercado de trabalho.

Há bem pouco tempo à angústia e ansiedade inerentes ao processo de escolha de uma profissão, notadamente à primeira, tinham basicamente dois vieses: eram minimizadas através de conversas, bate papo com os familiares e amigos. As pessoas de maior poder aquisitivo, adultos ou jovens, podiam recorrer a um orientador profissional, podendo este estar inserido em consultório particular ou ainda em empresas de consultorias ou em escolas particulares.

Nos dias atuais, a preocupação com a escolha profissional extrapolou os muros acadêmicos e científicos; a mídia tem dado sua parcela de colaboração, as revistas de circulação nacional têm abordado este tema, trazendo depoimentos de profissionais que atuam na área de orientação profissional, de jovens que vão fazer a primeira escolha; a televisão, também tem dado sua contribuição trazendo debates e, inclusive, com programas criados para orientar sobre as diversas profissões existentes, neste caso com depoimentos de alunos/acadêmicos e professores/ profissionais da profissão em pauta.

Apesar da exposição do tema na mídia e a expansão do serviço de orientação profissional nas universidades brasileiras, na prática, este ainda é um acesso privilegiado. A população mais carente nem sempre pode desfrutar desta informação ou serviço, tornando-a, muitas vezes, excluída de um apoio profissional competente. Apoio este que deveria ser extensivo aos jovens e familiares.

A globalização, dentre outros progressos das últimas décadas, fez com que $\mathrm{o}$ ato de realizar escolhas se antecipasse, onde o avanço tecnológico, ou seja, a era da informação cria um verdadeiro caleidoscópio na vida, notadamente na infância. Hoje as crianças e pré-adolescentes são estimulados precocemente a participarem da sociedade. Tais estímulos podem antecipar o ciclo de desenvolvimento, se compararmos com a geração que as antecederam, existem alguns fatores que, com certeza, contribuem para esta antecipação, por exemplo, os programas infantojuvenis que, com rara exceção, é um protótipo da programação do adulto, onde a precocidade é premiada. 
Pode-se levantar uma variedade de hipóteses para justificar tais procedimentos, mas não se pretende se ater a elas por não ser este o foco deste artigo, mas com certeza, a globalização vem acarretando mudanças no contexto mundial, contexto este que nos obriga a correr atrás do prejuízo, sob pena de ser "marginalizado".

Este novo paradigma, com certeza, interfere no desenvolvimento humano, podendo antecipar esta fase de desenvolvimento. No entanto, é na adolescência que se acentua os conflitos, principalmente, no momento em que a maioria dos jovens tem que tomar uma decisão quanto o caminho profissional a seguir.

Neste aspecto Rappaport (1998) argumenta que a escolha profissional na adolescência se apresenta como urgente e necessária, pois sinaliza o final da infância e a participação mais efetiva no mundo adulto.

A escolha profissional nesta fase, ou seja, na adolescência se torna mais angustiante, agora não é uma escolha no estilo de vestir, de escolhas momentâneas. Culturalmente existe um estereótipo de que a escolha por uma profissão é definitiva, como se esta fosse a única oportunidade de redirecionamento profissional.

Embora essa premissa não retrate a realidade, ela contribui para a ansiedade e angústia no momento decisório. Tornando este momento de tomada de decisão, um passo importante na conquista de um sentimento de independência, principalmente, se a escolha for por uma formação universitária, por questão cultural passa a ser a "inserção à vida adulta".

Deste modo, escolher uma profissão pode ser um dos caminhos para o ingressar no mundo adulto, conforme já comentado, ou ainda, se situar socialmente, uma vez que o trabalho e a ocupação são expressivos determinantes de "status social".

Com relação ao processo de escolha Super (1953) argumenta que a escolha se desenvolve por um longo período, como um processo contínuo, na primeira fase o desenvolvimento não se compatibiliza com a realidade, mas à medida que a faixa etária aumenta, há um maior envolvimento e compreensão desta realidade. $O$ autor enfatiza que na adolescência a escolha e o ajustamento emocional se confundem, provavelmente, pela necessidade de se fazer um reajustamento para a inserção na vida adulta e, por consequente, na trajetória profissional.

Levenfus (1997 p.35) nos lembra que "à medida que se cresce, grande parte da angústia a respeito de si mesmo liga-se às escolhas e aos conflitos surgidos na administração da própria vida”. A autora conclui enfatizando, optar por uma profissão é uma das maiores escolhas ao longo do ciclo vital.

Outro aspecto a ser considerado é que quando falamos em conflitos, em crise, não necessariamente nos referimos ao sentido patológico do termo, pois como bem coloca Osório (1992), a crise vital acontece ao longo da vida, desde o nascimento, o desmame, o início do processo de socialização, o vestibular (passagem para a vida adulta), dentre outras.

Agregado a esta fase, o novo século presencia um clima de constantes mudanças nas relações de trabalho, colocando em questão a necessidade de novas propostas que possam auxiliar as pessoas (jovens e adultos) na construção e desenvolvimento de suas carreiras. Elas precisam desenvolver já na fase decisória uma independência gradativa, de forma a habilitá-la para o trabalho, desenvolvendo a noção de gerenciamento de sua vida profissional, preparando-a para uma relação de emprego com ou sem vínculo empregatício, ou seja, para a empregabilidade.

Minarelli (1995) chama de empregabilidade, palavra usada inicialmente nos Estados Unidos como employability, equivalendo dizer que é a condição de dar emprego, ou a habilidade de ter emprego.

Conciliar este novo paradigma e o momento de escolha profissional é muito complexo, principalmente, se pensarmos que não estamos preparando, para este novo patamar, as pessoas que já participam do atual mercado de trabalho de relação de trabalho. O que dizer, então para a nova geração que participarão do mercado futuro?

Reconhecendo que uma das principais preocupações da adolescência é a indefinição quanto ao futuro profissional, justifica-se o presente programa, principalmente se reconhecermos que a maioria da população tem sua escolha dificultada, notadamente, as crianças e jovens oriundos de escolas públicas, este programa poderá ser um facilitador, um despertar para que os alunos desenvolvam ou incentivem às escolas a desenvolverem 
pesquisa sobre as diversas profissões, de acordo com o perfil da população alvo, visitas às universidades, escolas técnicas, dentre outras ocupações práticas que existem sem necessariamente passar pela escola formal (pedreiro, carpinteiro, vendedor, etc.).

Portanto, pretende-se fornecer instrumentos para que os alunos possam desenvolver estratégias que vão auxiliá-los no momento da escolha profissional, desmistificando assim, que a escolha profissional para ser adequada precisa necessariamente passar pela formação universitária, que ela precisa ser "pensada" só no momento da opção. Acredita-se que este programa deveria anteceder ao processo de Orientação Profissional, pois, o mesmo pretende fornecer subsídios para elevar o nível de autoconhecimento, propiciando momentos para auto-avaliação, afim de que possam melhor definir suas habilidades e aptidões para que no futuro possam ter subsídios com o auxílio do processo de orientação profissional planejar a carreira profissional.

\section{Diretrizes básicas do programa}

$\mathrm{O}$ processo de orientação profissional tem como foco principal à atuação em que a escolha remete a uma formação universitária, esta centralização pode ser justificada devido a maior conscientização da população de melhor poder aquisitivo que frequentam as escolas privadas onde em seu leque de "produtos" oferecidos entram também a OP, os fatores culturais e de status que ainda consideram, erroneamente, à formação universitária como a opção mais segura para o sucesso profissional.

Poucos são os trabalhos divulgados de OP em escolas públicas, mas precisamente, com a população mais carente. São vários os fatores de insucesso, dentre eles: falta de verba para deslocamento dos alunos, gerando desistência e consequentemente, desintegração do grupo; indisponibilidade dos pais para participarem de reunião de conscientização quanto à importância do processo de OP (dentre eles: o consentimento de participação do filho) nas escolas, falta conscientização à direção quanto à importância de destinar horário dentro da programação pedagógica para OP.

Desta forma, o programa de sensibilização para a escolha pretende resgatar junto à direção e alunos a importância de discutir e desenvolver programa de OP. Sendo o primeiro passo, o refletir sobre o processo de escolha. Este programa foi desenvolvido em parceria com a Seção de Processo Seletivo que tem, também, um trabalho de divulgação dos cursos oferecidos pela universidade, visando desenvolver a informação profissional de maneira mais abrangente.

Para melhor compreensão da proposta de sensibilização passa-se a descrever o formato atual do referido programa.

Objetivo Geral: Sensibilizar alunos do $2^{\circ}$ ano do ensino médio, oriundos de escolas públicas e privadas, para uma futura escolha profissional.

\section{Objetivos Específicos:}

a. Propiciar uma primeira reflexão sobre as mais diversas profissões; Possibilitar a informação profissional;

$b$. Estimular os alunos a buscarem apoio da família, escola e comunidade para auxilia-l os na futura escolha profissional;

c. Favorecer a interação e trocas de vivências entre os colegas, favorecendo a ampliação da relação interpessoal.

Coordenação do Programa: Professora titular da disciplina de orientação profissional e Psicóloga da Seção de Processo Seletivo da UNIVALI.

Caracterização da Clientela: Alunos do $2^{\circ}$ ano do ensino médio, oriundos de escolas públicas e privadas da região da Foz de Itajaí - SC. Devido à carga horária da atividade prática da referida disciplina, bem como o $\mathrm{n}^{\mathrm{o}}$ de acadêmicos regularmente matriculados na disciplina de orientação profissional, definiu-se por dar prioridade ao atendimento dos alunos desta fase. No entanto, à medida do possível tem-se procurado estender o programa para outras fases.

Recursos Humanos: Acadêmicos do Curso de Psicologia regularmente matriculados na disciplina de orientação profissional $\left(8^{\circ}\right.$ Período). Estes deverão se organizar, de preferência, em dupla.

Recursos Didáticos: dinâmicas de grupos, papel sulfite, caneta, lápis de cor, preto, TV/vídeo, Fita com os principais cursos da UNIVALI, informativo sobre cursos técnicos, bem como de outras universidades de 
acordo com o interesse da população alvo, e-mails de escolas técnicas e universidades, dentre outros.

Duração: Varia de acordo com o número de alunos e disponibilidade das escolas, podendo oscilar de $1 \mathrm{~h}$ e $30 \mathrm{~min}$ à $2 \mathrm{~h}$ cada encontro.

Local: Sala de aula das escolas públicas e privadas.

Estratégias Utilizadas: Após acordo com a direção das escolas públicas e privadas, agenda-se 2 encontros nas referidas escolas. Antes de iniciarem a atividade prática ( $1^{\mathrm{a}}$ e $2^{\mathrm{a}}$ fases), os acadêmicos são supervisionados pelas coordenadoras do programa. Estas supervisões, num total de duas (2), ocorrem nas aulas de Orientação Profissional, nas dependências da UNIVALI.

$1^{a}$ fase - Sensibilização para a escolha

$1^{\text {o }}$ passo) Abertura: apresentação dos acadêmicos e objetivos do encontro.

$2^{\circ}$ passo) Atividade Grupal: Convém salientar que os acadêmicos, mediante supervisão, poderão mudar a dinâmica/atividade grupal de acordo com o perfil dos alunos e interesse da dupla.

Sugestão de atividade:

a) $\mathrm{O}$ processo de escolha — Levantar junto aos adolescentes aspectos referentes ao tema, como por exemplo: O que é escolher uma profissão? Já discutiu este assunto na escola, caso positivo, como é o processo? - e em casa, com os pais?

b)A escolha propriamente dita — Quem já definiu? — caso negativo, quais as profissões que admira ou gosta? - Suas dúvidas e ansiedade. (Simbolizar através de desenho) — Após, socializar com os demais alunos.

Encerramento: Levantar com os alunos quais são os cursos/áreas (por exemplo: universitário, técnico) que querem ver apresentados no próximo encontro ( $2^{\mathrm{a}}$ fase — informação profissional).

No retorno da atividade prática, os acadêmicos fazem a socialização com os demais colegas da experiência vivenciada, recebendo orientação das coordenadoras (quando necessário). Antes de iniciarem a $2^{\mathrm{a}}$ fase, os acadêmicos são novamente orientados para a etapa de informação profissional, última fase. Neste momento, há a entrega de materiais sobre cursos oferecidos pela UNIVALI que poderá ser usado caso os alunos tenham apresentado interesse por algum curso desta instituição, formas de entrada na universidade, como ENEM (Exame Nacional de Ensino Médio), SAEM (Sistema de Avaliação de Ensino Médio, avaliação do Estado de Santa Catarina) e, finalmente, O Processo Seletivo Especial (Sistema de Ingresso próprio da UNIVALI, onde se considera o histórico escolar como critério de classificação) Também divulgação sobre os demais cursos universitários/técnicos de interesse da população alvo que foram levantados no final do $1^{\circ}$ encontro.

\section{$2^{a}$ fase - Informação profissional}

Através do material de divulgação, a dupla deverá orientar os alunos sobre os cursos oferecidos pela Universidade mais próxima para os que têm interesse em ingressar num curso de nível superior, bem como divulgar os cursos de outras localidades de interesse na população alvo, além de orientação com relação a curso técnico/prático de acordo com o interesse da população alvo.

Esta fase tem por objetivo oferecer orientação para que os alunos continuem a pesquisar sobre os diversos cursos universitários/técnicos, bem como outros interesses que possam surgir a partir da inserção no mercado de trabalho.

Encerramento: A dupla deverá fazer devolutiva à direção e ou Orientadora educacional da escola em questão, apresentado a súmula do que foi trabalhado e preenchendo um modelo de avaliação do programa.

Este programa é encerrado com socialização da $2^{\text {a }}$ fase e avaliação do programa que poderá ser alterado conforme sugestões dos acadêmicos e da direção das escolas.

\section{Resultados obtidos}

Até o $1^{\circ}$ semestre de 2002 o programa atendeu 1.194 alunos oriundos de escolas públicas e privadas. Destacam-se as seguintes avaliações e sugestões avaliação da direção das escolas, dos acadêmicos, bem como as expectativas de alguns alunos com relação à escolha profissional. 


\section{Direção das escolas}

\section{Escolas Públicas}

"Abre um leque de perspectiva profissional. Nossos alunos são pouco informados";

"Gostaríamos que fossem atingidas todas as turmas, sem preferência de fase";

"Além da sensibilização, seria necessária a orientação vocacional e profissional";

"A dificuldade é encontrada quando trabalhamos os alunos em sala de aula, pois o cronograma é restrito. Os professores encontram dificuldades em conseguir ceder aulas devido ao aperto do calendário escolar";

“A principal dúvida e necessidade são de cunho financeiro, visto ser um colégio onde o público alvo possui um nível socioeconômico baixo. Assim, suas aspirações estão relacionadas com suas possibilidades financeiras";

"O projeto proposto pelos acadêmicos de Psicologia teve como objetivo promover um momento de sensibilização no qual os alunos puderam fazer uma reflexão sobre a questão das escolhas profissionais".

\section{Escolas Privadas}

"Acredito que a divulgação é de extrema importância para os alunos. Eles precisam saber mais sobre os diversos cursos e profissões, campo de trabalho e, até mesmo, pareceres salariais";

"Não deveria haver esta divulgação sob o nome de orientação profissional, pois os alunos veem isto como testes vocacionais";

"Oportuniza aos alunos as novas áreas de conhecimento e habilidades, faz com que se amplie os horizontes da informação e consequentemente o acesso ao saber levando o aluno a desenvolver capacidades intelectuais que o tornarão apto a escolher uma profissão que lhe torne capaz e satisfeito quanto à execução da mesma";

“... toda e qualquer contribuição em relação a 'educação', é uma excelente iniciativa quanto ao exercício de cidadania destes e daqueles que se propuseram e colaboraram para o desenvolvimento deste projeto";

"Desenvolver alguma ideia de trabalho junto aos professores, como apoio para as atividades desenvolvidas em sala de aula";

"Maior integração e contato direto com a universidade, isso diminuiria muitas inquietações de alunos e ajudaria para buscar maiores informações sobre as profissões e como está o mercado de trabalho".

\section{Acadêmicos}

"Vejo este projeto como uma das formas de inserção da Psicologia junto às instituições educacionais";

"Trabalhar com adolescentes é gratificante, porém para o trabalho ser produtivo precisa-se reuni-los em pequenos grupos (máximo 20)";

"É importante realizar um trabalho de sensibilização junto aos pais";

"O programa de sensibilização sem dúvida tem que dispor de mais horas para com os estudantes, devido a ansiedade frente a dúvida da escolha ser demasiada";

"... no instante em que sentei junto com minhas colegas em frente do computador e começamos a escrever sobre a nossa prática. Foi nesse momento que percebemos o quanto aprendemos, o quanto pudemo auxiliar naquelas duas horas em que ficamos com os adolescentes esclarecer as suas dúvidas";

“... poderia ser feito também um trabalho com as orientadoras das escolas, preparando-as para atuarem durante o transcorrer do ano letivo. O trabalho poderia ser feito com duplas ou trio divididos, um grupo trabalharia com os orientadores e outros com os alunos".

\section{Comentários dos alunos sobre as perspectivas de escolha profissional}

\section{Alunos das Escolas Públicas}

"No mundo em que vivemos vale mais a penas ter dinheiro do que sonhar com algo que nos realize profissionalmente";

"Quando me perguntam sobre minha futura profissão eu fico em dúvida", 
"Quando me perguntam sobre a minha futura profissão eu respondo que vou mexer na área de esportes especificamente voleibol";

"Às vezes fico em dúvida no que pretendo fazer (turismo ou direito)";

"Eu acho que quero ser pastor ou médico pelo fato de falar em cristo e não querer mal para os outros";

"Pretendo terminar o $2^{\circ}$ grau e fazer um curso técnico, se possível faculdade".

Alunos das Escolas Privadas

"Meu pai tem um hotel, então... já to dentro, tem que fazer turismo";

"Medicina é o sonho de minha família, não meu... já foi, hoje não é mais, mas se eu não fizer ela morre";

"Gostaria de fazer educação física, gosto de estar na academia, dando aula... o problema são os outros, professor de educação física além de ganhar pouco tem muito preconceito, as pessoas acham que eles estão ali só para brincar, não sei... vou fazer jornalismo então...";

“... eu gosto muito de inglês, mas... o que eu vou fazer, letras?, não sei... comércio exterior? Não sei...”;

"Todo mundo diz que me veem como dentista... eu me vejo como dentista, foi o que eu sempre quis fazer";

"Eu por mim não queria fazer nada, mas já que tem que fazer vou tentar medicina..."

\section{Referências}

Andrade, Patrícia Carlos de. (2000). Oriente-se: Guia de profissões e mercado de trabalho. Rio de Janeiro: Oriente-se Ed. Educ. Ltda.

(1997). "O ato de escolher". In: Psicodinâmica de Escolha Profissional, Levenfus, Rosane Schotgues e Colaboradores. Porto Alegre: Artes médicas, p.183 - 187.

Bock, Ana Mercês, et al. (1995). A Escolha Profissional em Questão. São Paulo: Casa do Psicólogo.
Lehman, Yvette Piha (1995). "O papel do orientador profissional: revisão crítica”. In: A Escolha Profissional em Questão. Bock, Ana Mercês, et al. São Paulo: Casa do Psicólogo, p.239 - 247.

Levenfus, Rosane S. (1995). Faça Vestibular Com Seu Filho. Faça O Vestibular Com Seus Pais. Porto Alegre: Artes Médicas, p.36-41.

Minarelli, J. A. (1995). Empregabilidade O Caminho das Pedras - Como Ter Trabalho e Remuneração Sempre. São Paulo: Ed. Gente.

Oliveira, Ma. Beatriz L. de; Chakur, Gabriela de Sá L. (Org.) (2000). "Adolescência e escolha profissional". In: Leite, César Donizeti P.; Salles, S. Leila Ma. F. \& Oliveira, Ma. Beatriz L. de. Educação. Psicologia e Contemporaneidade. Cabral Ed. Univ., p.154-169.

Soares, Dulce Helena Penna (2000). "As diferentes abordagens em orientação profissional" In: Lisboa, Marilú Diez e Soares, Dulce Helena Penna. Orientação Profissional em Ação: Formação e prática de orientadores. São Paulo: Summus ed, p.24 - 47.

Super, D.E. (1953). A theory of vocational development; amer. Psychol. 


\section{A reorientação ocupacional/profissional após a mastectomia: uma nova proposta de inserção social}

Maria Clara de Jonas Bastos ${ }^{1}$ Josiane Aparecida F. de A. Prado ${ }^{2}$

Ao longo do processo histórico as mulheres representam um papel social ligado à geração e perpetuação da espécie, há algumas décadas atrás e ainda hoje em menor proporção, vemos comparar o ciclo biológico da mulher com o ciclo da natureza, por exemplo: o ciclo menstrual, a influência da lua na data de nascimento, notadamente a do primeiro filho. Como a "mãe" natureza, as mulheres também têm como tarefa primária gerar filhos.

O leite materno é uma rica fonte de alimento, além de nutrir, protege o bebê contra infecções e viroses. Através do seio/amamentação, a nutriz tem a oportunidade de promover a seus filhos a saúde, no termo mais geral que a palavra sugere.

Quanto à estética, o seio tem estado em evidência. O Brasil é um dos países que mais realiza cirurgias de implante de silicone, o que, de certa forma, tem contribuindo para a mudança dos padrões de beleza estética. Tendo o seio como fonte de vida e sensualidade. O diagnóstico de Câncer de Mama e a possível mutilação proveniente da cirurgia, proporcionam como sugere Kovács (1996), profundas modificações na vida destas pessoas, experimentadas como mortes em vida, influenciando em suas características da personalidade, experiências de vida, atividades que não poderão mais ser executadas.

Gentil (2001) aponta que em nosso país o câncer de mama acomete uma em cada nove mulheres. Dados do Ministério da Saúde (1995) indicam que o câncer de mama acomete mulheres a partir dos 25 anos de idade, sendo que a maioria dos casos ocorre entre 45 e 50 anos. Destes, 90\% são descobertos pelas próprias mulheres, em $70 \%$ dos casos são diagnosticados

\footnotetext{
${ }^{1}$ Mestre em Psicologia Social e da Personalidade, Psicóloga/Supervisora do Curso de Psicologia da UNIVALI.

${ }^{2}$ Mestre em Psicologia, Psicóloga Clínica, Professora e Supervisora de Estágio do Curso de Psicologia da UNIVALI.
}

tardiamente (Urbanetz, 1999), o que dificulta a cura definitiva. O diagnóstico de câncer de mama e seus tratamentos promovem grande impacto na vida das mulheres e também, das pessoas ligadas a elas. Além do impacto da doença e do medo da morte, sua rotina de vida passa a ser alterada.

Algumas mulheres necessitam passar por procedimentos cirúrgicos e, posteriormente, por tratamentos. Estes são diferenciados, pois dependem do tipo de câncer que a paciente apresentar. A extração da mama não significa que o câncer tenha sido totalmente eliminado. Antes ou após o procedimento cirúrgico, há a necessidade da realização de tratamentos complementares, que têm por objetivo eliminar as células doentes, diminuindo a possibilidade que a paciente apresente metástase. Os principais são a quimioterapia, radioterapia, hormonioterapia e reconstrução mamária.

O acompanhamento médico de mulheres com câncer de mama já tratado e sem evidência da doença, faz-se necessário, mesmo após a mastectomia e os tratamentos. Esse acompanhamento é denominado rotina de seguimento.

Araújo e Arraes (1998) destacam que a percepção de si mesmo como curado não acontece prontamente para o doente que teve câncer. Os autores apontam a sobrevivência do câncer como sendo paradoxal, pois, o fato das pessoas estarem curadas não significa que elas sintam-se curadas.

Após a mastectomia as pessoas ficam impossibilitadas de realizar atividades corriqueiras e rotineiras, como, por exemplo, levantar os braços, pegar peso e raspar as axilas. Seu quotidiano tem que ser alterado, o que promove a necessidade de ter que aprender a conviver com as limitações, desestruturando um padrão de vida e de atividades profissionais e pessoais antes existentes.

Prado (2002) apontou em seu estudo que em decorrência da mastectomia, as mulheres passaram por experiências dolorosas que possibilitaram-nas configurar uma nova identidade. Atividades quotidianas como a rotina da limpeza da casa, ou ir ao trabalho, deixaram de ser executadas. Houve a necessidade de reestruturar e de reorganizar a própria vida e novas experiências foram assimiladas promovendo ajustes para um novo quotidiano. 
Lago (1999) descreve a identidade como sendo uma construção em permanente processo de significação. Novos significados e identificações estão sendo elaboradas constantemente. No caso da mastectomia, sucessivos esforços são suscitados para vencer cada etapa da doença promovendo novas adaptações que a doença/tratamento impõe.

Em entrevista realizada com quatro mulheres, Prado (2002) constatou que o tratamento do câncer oportunizou o contato com pessoas fora do ambiente familiar ou profissional. Das participantes do estudo, uma exercia atividade profissional, sendo as demais donas de casa. Antes do diagnóstico de câncer, todas tinham um contato social restrito ou inexistente, mesmo a participante que trabalhava como operária, pois segundo relato, seu contato com outras pessoas no ambiente de trabalho era estritamente profissional.

Conhecer pessoas hospitalizadas ou em tratamento proporcionou novas amizades e objetivos de vida. Compartilhar a própria experiência com pessoas que estão passando por situações semelhantes a que passaram, realizar visitas hospitalares a doentes e participar de uma associação de doentes de câncer, tornou-se rotina na vida de três das quatro mulheres entrevistadas, promovendo o que uma participante da pesquisa denominou objetivo de vida e que Woodward (2000) chama de novos movimentos sociais. Para esse autor, as identidades são diversas e mutáveis, tanto nos contextos sociais, nos quais elas são vividas, quanto nos sistemas simbólicos por meio dos quais as pessoas dão sentido às próprias posições.

A experiência da doença, hospitalização e vulnerabilidade quanto à continuidade da vida, promoveu o que Super (apud Martins,1978) denomina trabalho como estilo de vida, ocorrendo um ajustamento pessoal e profissional em consonância com os valores pessoais e culturais.

O sentimento de ter vencido o câncer é forte e presente no discurso destas mulheres. Ajudar pessoas doentes é uma forma de superar a mutilação e as sequelas físicas e emocionais. É demonstrar que o câncer foi derrotado, não a saúde. Estão curadas, são vencedoras e como tal uniram-se na tentativa de encorajar outras pessoas nesta batalha contra a doença. Experimentar o próprio sofrimento e conviver com dores alheias promoveu a necessidade de mudar e ajudar a melhorar a vida de pessoas em situações semelhantes. Uniram-se com este objetivo. A identificação foi um elemento aglutinador para a mudança de valores e, consequentemente, de ações (Prado, 2002, p.46)

A inserção de um profissional que atue na área de orientação profissional/ocupacional, através de uma equipe multiprofissional, pode facilitar o processo de re-escolha ou re-opção tanto profissional quanto de vida. Soares (2000, p.40), argumenta que "a reorientação pode ocorrer em diferentes momentos da vida do indivíduo".

Embora não haja um único enfoque teórico em orientação profissional, Super (1972) prefere trabalhar o processo de escolha, em qualquer fase da vida da pessoa, baseado na teoria de autoconceito que pontua que as experiências iniciais com outras pessoas, as situações de vida, podem indicar caminhos para ocupações futuras, esses caminhos são delineados a partir de identificações, experiências de vida. Neste caso, o processo de reorientação após mastectomia, ou seja, em um momento de redirecionamento de projeto pessoal e ocupacional/profissional deve, primeiramente, basear-se na reorientação do conceito de si mesma, de acordo com o histórico de vida e vivência do processo do tratamento do câncer de cada mulher.

Para maior esclarecimento, quando nos referimos à palavra ocupacional estamos nos aludindo a qualquer atividade que a pessoa exerça, não visando, necessariamente, uma remuneração, por exemplo: gestores sociais, voluntariado. Já a palavra profissional se refere à relação mulher trabalho. Podendo se referir à relação com ou sem vínculo empregatício.

A redescoberta da capacidade de fazer/criar algo para si e para o próximo, promoveu a redescoberta do viver, mesmo após ter padecido de uma doença grave e mutiladora como o câncer. A reorientação profissional/ocupacional surge quando a identidade pessoal e profissional/ocupacional são ameaçadas, ocorrendo um processo de desestruturação; neste momento há a necessidade de resgatar o significado do trabalho, do "prazer". O relato que segue, corrobora à necessidade de reorientação profissional/ocupacional (Prado, 2002):

Hoje faço coisas que eu não fazia. Tenho uma vida social, tenho minha vida própria! Eu comecei a trabalhar como voluntária. Até aî eu não tinha vida social. Eu queria passar para as pessoas que eu 
estava bem, que eu tinha passado por aquele problema mas estava bem, estava curada, tinha superado, e que elas também poderiam conseguir! Eu queria passar meu exemplo para elas...

Comecei a pensar numa forma de atender quem não tinha condições, porque eu tinha condições financeiras, mas, e o pobre que não tem?

A maneira com que este projeto futuro será estruturado varia de acordo com o perfil de personalidade e experiência vivenciada no grupo familiar e social, se for de apoio e incentivo a reestruturação da identidade pessoal e profissional poderá ser menos traumática. Aqui a participação da família, de amigos e colegas de trabalho, são primordiais para o sucesso nessa nova trajetória.

Krawulskie e Cols (apud Soares, 2000) apontam que o reorientador deve contribuir na reflexão sobre o projeto de vida pessoal e profissional, relacionando-os aos novos caminhos e possibilidades pessoais. Pode-se propor, inclusive, uma atuação junto à empresa, caso seja necessário, no momento de readaptação do profissional que se afastou para tratamento, orientando para a readaptação à atividade exercida ou para uma nova atividade, tudo vai depender do tipo de sequela deixada.

Convém salientar que, esta proposta pode ser aplicada a qualquer ambiente social, ou seja, àqueles constituídos de maneira formal ou informal. Desta forma, pode-se também aplicar ao trabalho voluntariado, assessorando na inserção desta nova mulher à sociedade, sendo também necessário a orientação à família e à comunidade, evitando os cuidados exagerados que, por certo, não facilitarão o processo de reinserção social.

Ao psicólogo, cabe estar inserido na equipe interdisciplinar: mastologistas, oncologistas, enfermeiros, cirurgiões plásticos, fisioterapeutas, radioterapeutas e nutricionistas. Informar e discutir assuntos pertinentes à saúde, é uma forma de promover a saúde do próprio cuidador, para que este possa esclarecer e contribuir para o bem estar da mulher que, neste caso específico, teve câncer de mama. E também contribuir para a desmitificação de que ter câncer, necessariamente, significa sentença de morte, colaborando com informações claras e sinceras, considerando não a doença, mas a pessoa que esteve ou está doente. Cabe a reorientação ocupacional/profissional auxiliar as mulheres mastectomizadas a superar as diversas fases de enfrentamento: diagnóstico, tratamento e após o desaparecimento da doença.

A reinserção ocupacional e, consequentemente, social destas mulheres, diferentemente do que ocorre com pessoas que já tiveram uma experiência profissional anterior e querem mudar em decorrência de insatisfações no trabalho ou na universidade, foi pautada em experiências pessoais: na vivência quotidiana de terem sido acometidas por uma doença grave, promovendo mudanças, muitas vezes indesejadas, em suas vidas. A nova ocupação para três das quatros mulheres deste estudo, foi consequência da reflexão sobre a vivência da doença que proporcionou um novo objetivo/projeto de vida.

Magalhães recorre ao construto teórico de Super (Apud Levenfus, Soares e Cols 2002, p.387) para pontuar as necessidades, valores interesses ocupacionais:

... as necessidades estão relacionadas a condições fisiológicas, e à sobrevivência, e são experienciadas como um sentimento de falta de algo e como um desejo de preencher esta falta. Os valores são o resultado da socialização, que estabelece os tipos de objetivos que as pessoas perseguem a fim de satisfazer suas necessidades. Portanto, percepção de uma falta leva a valorizar algo que parece suprí-la. Esse algo é ainda definido abstratamente através dos rótulos aplicados a valores como, por exemplo, altruísmo, poder e beleza. E, por fim, os interesses são as atividades nas quais o indivíduo espera concretizar seus valores.

Desta forma, a inserção social das mulheres do citado estudo, foi pautada pelas vivências pessoais e que envolvem necessidades, valores e interesses pessoais, descobertos após uma vivência traumática que é a mastectomia, alterando um padrão de vida anterior, transformando o que antes eram apenas obrigações nos cuidados com a família, em ocupações fora do ambiente doméstico. Ocupar-se em auxiliar pessoas doentes, em hospitais ou associações, passou a ser a razão fundamental de suas escolhas pessoais: um novo sentido à vida. 
Definição dos termos

Câncer de mama Tumor maligno da glândula mamária

\begin{tabular}{c|l} 
Mamografia & $\begin{array}{l}\text { Exame radiológico que permite detectar calcificações } \\
\text { microscópicas na glândula mamária }\end{array}$ \\
Metástase & $\begin{array}{l}\text { Presença de câncer em outros tecidos ou órgãos à distância do } \\
\text { tumor primário. E característica de todos os cânceres. Dá-se } \\
\text { através do sistema circulatório e linfático }\end{array}$
\end{tabular}

\section{Referências}

Araújo, T.C.C.F. \& Arraes, AR. (1998). A sobrevivência em oncologia: uma vivência paradoxal. Psicologia Ciência e Profissão, 18 (2), 02-09.

Ferreira, M.L.S.M. (1999). Vivendo os primeiros meses de pósmastectomia: estudo de caso. Tese de Doutorado em Enfermagem, Universidade de São Paulo (USP), Ribeirão Preto.

Gentil, AC. (2001). Câncer de mama. Revista Brasileira de Cancerologia. 47 (1), 09-19.

Gimenes, M.G.G. \& Queiroz, E. (1997). As diferentes fases de enfrentamento durante o primeiro ano após mastectomia. In: M.G.G. Gimenes \& M.H Fávero. (Orgs). A mulher e o câncer (p.176-221) Campinas, SP: Psy.

Kovács. M . J. (1996). Morte em vida. In: M. H. P. F. Bromberg, M. J. Kovácks. M. M.M. Carvalho \& V. A . Carvalho. Vida e morte: laços da existência. São Paulo: Casa do Psicólogo

Lago, M. C. S. (1999). Identidade: A fragmentação do conceito. In: AL. Silva, M.C.S. Lago \& T. Ramos (Orgs.). Falas de gênero (p.119129). Florianópolis: Mulheres.

Levenfus, RS; Soares D.H. e Cais (2002). Orientação vocacional/ocupacional: novos achados teóricos, técnicos $e$ instrumentais para a clínica, a escola e a empresa. Porto Alegre: Artemed.

Martins, C. R (1978) Psicologia do comportamento vocacional. (p.59 - 66) São Paulo: EPU.
Ministério da Saúde. Instituto Nacional de Câncer — Pro-Onco. (1995). Câncer no Brasil. (voI. II). Rio de Janeiro: Pro-Onco.

Prado, J. A . F. de AA .(2002) Supervivência: novos sentidos na vida após a mastectomia. Dissertação de Mestrado em Psicologia, Universidade Federal de Santa Catarina (UFSC), Santa Catarina.

Soares, Dulce H.P. As diferentes abordagens em Orientação profissional. In: Lisboa, Marilu Diez \& Soares, Dulce H.P.(Orgs) (2000), Orientação profissional em ação: Formação e prática de orientadores (p.24-47). São Paulo: Summus.

Super, Donald E. \& Bohn JR, Martin (1972). Psicologia Ocupacional. São Paulo, Atlas, 229 p.

Urbanetz, A A (1999). Tratamento do câncer da mama. In: Lins L.C. \& M.C.N. Bernz (Orgs), Mastologia prática: guia de orientação (p.157172). Blumenau: Editora da Furb.

Woodward, K. (2000). Identidade e diferença: uma introdução teórica conceitual. In: Silva, T.T. (Org.), Identidade e diferença. (p.7-72). Petrópolis: Vozes. 


\section{É hora do espetáculo da perversidade: o aprisionamento da subjetividade dentro dos realities shows}

\section{Regina P. Christofolli Abeche ${ }^{1}$ Ângela Caniato ${ }^{2}$ Lara Hauser Santos ${ }^{3}$}

Você tem alma? Essa pergunta — filosófica, teológica ou simplesmente incongruente — encerra hoje uma nova dimensão. Confrontada aos neurolépticos, à aeróbica e ao massacre da mídia, a alma ainda existe? (Kristeva, 2002, p.9).

Um fenômeno recente tem chamado a atenção de diversos estudiosos: os realities shows. Estes programas estão tomando conta da televisão mundial, em especial a brasileira neste momento. Tais programas expõem seus participantes a situações limites e dão margem a uma série de análises. O enfoque deste trabalho será no Big Brother II, veiculado pela Rede Globo de Televisão, já que este se manteve entre os quatro maiores índices de audiência da emissora ${ }^{4}$ enquanto esteve no ar, o que evidencia seu alto alcance populacional. Lançar-se-á um olhar microscópico, especialmente nos valores embutidos na estrutura e funcionamento do programa, bem como nas características da subjetividade dos participantes, principalmente do vencedor, aspectos estes que difundem uma forma de ser na atualidade.

O Big Brother surgiu em 1999, na Holanda e foi criado pela produtora Endemol, uma das maiores empresas de entretenimento da Europa. O nome Big Brother foi inspirado no livro "1984", do escritor inglês George Orwell. No livro, todos os habitantes de um país fictício são vigiados diariamente por câmeras que funcionam como os olhos do governo. $\mathrm{O}$ autor alerta para o perigo de estarmos caminhando para uma sociedade controlada por câmeras. Passados pouco mais de 50 anos da

\footnotetext{
1 Professora do Departamento de Psicologia da Universidade Estadual de Maringá, doutoranda da Universidade Metodista de São Paulo.

${ }_{3}^{2}$ Professora Doutora do Departamento de Psicologia da Universidade Estadual de Maringá.

3 Acadêmica do curso de psicologia na Universidade Estadual de Maringá, bolsista $\mathrm{PIBIC/CNPq-UEM}$

${ }^{4}$ Este dado é da Folha de São Paulo, caderno Tv Folha, no período de maio a julho de 2002.
}

publicação do romance de Orwell, o temor ao totalismo cedeu lugar à sedução, através da invasão de câmeras em programas televisivos.

Em 2000, o programa Big Brother começou a ser exportado para outros países, como Alemanha, Espanha, Estados Unidos, Inglaterra, Portugal, Suíça, Suécia e Bélgica. Em todos eles o programa foi um sucesso, não só na televisão, como também na Internet. Seus participantes e vencedores tornaram-se famosos do dia para a noite e faturaram prêmios e dinheiro.

Para entender melhor a dinâmica do programa, serão expostas algumas de suas regras fundamentais:

1. O número de participantes foi 12 , previamente selecionados pela Rede Globo de Televisão. Estes permaneceram confinados em uma casa com 38 câmaras, sendo vigiados 24 horas por dia por um período de 60 dias. $\mathrm{O}$ número de dias poderia sofrer pequenas alterações no decorrer do programa;

2. Antes de iniciar o programa os 12 participantes ficaram reclusos por 7 dias em um quarto de hotel e não mantiveram nenhum tipo de contato entre eles, nem com o mundo externo;

3. A cada semana dois participantes eram indicados para o "paredão", sendo um escolhido pelo líder e o outro eleito via votação sigilosa por parte de grupo. Apenas um era eliminado, conforme votação feita pelos telespectadores;

4. A votação para o paredão era realizada no confessionário, espaço este no qual cada participante tinha privacidade em relação aos outros membros, uma vez que o que diziam ali não poderia ser revelado ao grupo durante a permanência na casa. $O$ confessionário era utilizado também, para a direção se comunicar individualmente com os participantes;

5. Depois da eliminação semanal de cada participante, teve-se uma final com 2 pessoas. O telespectador, via telefone e/ou internet, escolheu o

\footnotetext{
${ }^{5}$ Termo utilizado pelo programa como local no qual os participantes aguardam para serem excluídos ou não da casa. Em uma alusão a ideia de presos que aguardam fuzilamento/exclusão.
} 
vencedor que levou a quantia de 500 mil reais, sendo que o segundo e terceiro colocados ganharam 30 e 20 mil, respectivamente.

6. Cada participante recebeu um microfone, o qual devia estar constantemente ligado durante a permanência na casa;

7. Era proibido o uso de qualquer meio de comunicação entre os participantes que não pudesse ser capturado pelas câmeras ou decodificado pelo público (escrita, gestos, etc.);

8. Os participantes não tinham acesso às notícias do mundo externo, pois na casa não havia telefone, rádio, televisão, jornal, revista, internet e etc.;

9. A cada semana era eleito um líder através de uma prova, estabelecida pela direção do programa;

10. O líder tinha algumas regalias tais como: imunidade, quarto privativo, uma sessão de cinema, um frigobar abastecido e também o direito a conversar com internautas;

11. A cada semana ocorria a prova da comida que devia ser cumprida em grupo, para que recebessem o Kit de alimentação. No caso desta não ser realizada com sucesso, não recebiam o Kit e passavam a semana apenas com sal, arroz, carne seca e doce de leite;

12. No caso de agressão física o participante seria excluído da casa;

13.Entre 10:00 e 12:00 horas ocorria o "toque de despertar", onde todos os participantes eram obrigados a acordar e levantar;

14. Os participantes tinham obrigações com a manutenção da rotina doméstica, tais como, cozinhar, lavar, passar, limpar a casa, etc.;

15. Apesar de não ser uma regra, vale a pena destacar que durante todo o programa havia festas proporcionadas pela direção com frequência de pelo menos uma vez por semana e recebiam ainda, visitas esporádicas de artistas, jogadores de futebol e apresentadores de programas de televisão.

O programa Big Brother Brasil foi exibido diariamente, em horário nobre, sendo que nas $2^{\mathrm{a}}, 4^{\mathrm{a}}, 5^{\mathrm{a}}$ e $6^{\mathrm{a}}$ feiras havia apenas edição. $\mathrm{Na} 3^{\mathrm{a}}$ feira, sábado e domingo o programa era transmitido ao vivo intercalado com edições. Nestes dias o programa era conduzido por um "animador" que interagia com os participantes da casa e com o telespectador.

Este estudo tem como base a constatação empírica e de autores como Thompson (1998), Guareschi (2000) e Ramonet (1999) entre outros. Todos estes mostram que vivemos hoje, uma "cultura midiática", de modo que é impossível entender qualquer fenômeno fora do grande capítulo da comunicação. Segundo Guareschi (2000), as pessoas adultas dos países ocidentais gastam entre 25 a 30 horas por semana olhando a televisão. Isto, sem contar o tempo que elas empregam lendo jornais, livros, revistas e consumindo outros produtos das indústrias de comunicação de grande escala transnacionais. Há poucas sociedades no mundo de hoje que não foram atingidas pelas instituições e mecanismos da comunicação, consequentemente, que não estejam abertas às imagens e formas simbólicas mediadas pelos meios de comunicação de massa.

Desde o início das sociedades modernas, os meios de comunicação contribuíram decisivamente para a construção da subjetividade dos seres humanos. Sempre em sintonia com o surgimento e consolidação das sociedades capitalistas. modernas, os meios de comunicação desenvolveramse de forma espantosa. E impossível pensar o mundo contemporâneo, sem levar em conta o papel da mídia. Um dos traços fundamentais deste mundo contemporâneo é exatamente o inesgotável fluxo de imagens e de conteúdos simbólicos, disponibilizados pelos meios de comunicação a um número cada vez maior de pessoas, e que de certa maneira, conformam a realidade, as relações sociais e a subjetividade individual.

Chomsky $^{6}$ apud Guareschi (2000) afirma que os meios de comunicação de massa servem como sistemas de comunicação de mensagens e símbolos para a população em geral, cuja função é divertir, informar, distrair, como também influenciar os indivíduos com valores, crenças e códigos de comportamento.

Atualmente o individuo é visto quase que exclusivamente no seu papel de consumidor. Em decorrência disso, as mercadorias da indústria se orientam segundo o princípio de sua comercialização e não segundo seu

${ }^{6}$ CHOMSKY, Noam. Propaganda Model. In: Herman, E. CHOMSKY, N. Manufacturing concert. The Political Economy in the Mass Medic. New York: Pantheon Books, 1988 (p.1$35)$. 
próprio conteúdo e figuração adequada. No conceito de Indústria Cultural, Adorno (1986) esclarece sobre os produtos adaptados ao consumo das massas e que em grande medida determinam esse consumo. O consumidor não é o senhor, como a Indústria Cultural gostaria de fazer crer. Ele também não é o sujeito dessa indústria, mas sim seu objeto. A Indústria Cultural é importante como formadora da consciência de seus consumidores. Segundo Adorno,

as ideias de ordem que ela inculca são sempre as do status quo. Elas são aceitas sem objeção, renunciando a dialética. Através da ideologia da Indústria Cultural, o conformismo substitui a consciência, a ordem por ela transmitida não é confrontada com o que ela pretende ser ou com os reais interesses dos homens (1986, p.97).

A Indústria Cultural, de acordo com Adorno (1986), impede a formação de indivíduos autônomos, independentes, capazes de decidir conscientemente. Também está intrinsecamente ligada aos elementos do mundo industrial, na qual exerce um papel específico de portadora da ideologia dominante. Esta, atribui sentido a todo o sistema unido à ideologia capitalista, a qual, contribui para falsificar as relações dos homens com outros homens, bem como dos homens com a natureza.

Todos estes aspectos têm forte influência no processo de padronização (Adorno, 1986) dos indivíduos, que é a eliminação total da diferença, com a uniformização de todos as pessoas. Assim, a Indústria Cultural é a ferramenta utilizada para se alcançar esta padronização. Haja visto que, todos nós assistimos aos mesmos programas, consumimos os mesmo produtos, usamos as mesmas roupas. Há também uma padronização do homem no aspecto do mundo interno, porque até a forma de pensar, sentir, desejar, vivenciar, relacionar-se está seguindo aos padrões, ou seja, até o âmago da vida interna está sofrendo a influência opressora da mídia. Todos seguem cegamente o que ela nos coloca como certo, tornando-nos exatamente iguais, com a total eliminação da diferença. Este processo tem como consequência o sofrimento psicossocial.

Outro aspecto dessa padronização, é a ilusão de liberdade a qual estamos submetidos (Adorno, 1986), porque acreditamos que somos livres para escolher. Este mecanismo da Indústria Cultural é tão perverso que além de nos tornar todos iguais, exige que sejamos "diferentes". Assim, temos uma infinidade de marcas para escolher, o que nos faz acreditar que estamos livres para tal escolha. Mas isso não é real, porque em sua essência todos os produtos são iguais, haja visto que uma sociedade que é guiada pelos princípios de comercialização, faz com que os produtos percam a importância de conteúdo e fiquem restringidos à aparência. Esta falsa liberdade só vem fomentar o individualismo exacerbado no qual vivemos, sob o constante bombardeamento de slogans como "você é único", "você deve ser diferente" e outros.

Costa (1984) ao discutir sobre a educação psicológica, introduz a ideia de que esta, atinge seu objetivo quando consegue formar um Tipo Psicológico Ordinário (p.73), que é a resposta ao que a sociedade pede em determinado momento. Portanto, cada contexto histórico terá o seu próprio Tipo Psicológico Ordinário.

Tipo Psicológico Ordinário é a normatização dos indivíduos, em que todos devem corresponder à norma, sendo ela mesmo, um conjunto de atributos relativos à subjetividade padrão que existe na sociedade. Esta é a universalização de particularidades emocionais previamente definidas como saudáveis (Costa, 1984, p.72), ou seja, elimina-se toda diferença em busca de uma padronização. Todo esse processo se dá a partir de uma violência simbólica, que de acordo com Costa, é a "imposição de enunciados sobre a realidade que leva o indivíduo a adotar como referencial exclusivo de sua orientação no mundo, a interpretação fornecida pelo detentor do saber" (p.75). Em outras palavras, é através da intimidação ideológica dos indivíduos, que se alcança a adaptação dos mesmos. Sobre isto Guinsberg ${ }^{7}$ apud Caniato (1995, p.244), diz:

Uma violência que não se apóia na força das armas e da repressão aberta e sim, apela à interiorização de suas premissas, normas, leis e ideias na subjetividade dos casualmente chamados "sujeitos sociais" (...) [A garantia do funcionamento da sociedade fica mantida pela] internalização das suas concepções ideológicas em cada um dos seus sujeitos: quando assim ocorre, a repressão direta se exerce só contra o transgressor, isto é, sobre os que violam as normas.

${ }^{7}$ GUINSBERG, Enrique. Médios Masivos, Salud Mental y Derechos Humanos. Trabalho apresentado na Plenária da III Conferência Salud, Represión Política y Derechos Humanos. Santiago do Chile, 24-29 novo 1999. 
Com isso, podemos coadunar o que vimos em Adorno, com o que vimos em Costa e chegar à conclusão de que a formação do Tipo Psicológico Ordinário em qualquer momento, se dá pela padronização, a qual tem como principal ferramenta, a Indústria Cultural.

Outros aspectos a serem considerados, são os valores implícitos no programa. Pode-se perceber estes valores através de sua estrutura e funcionamento, tais como: confinamento, vigilância, exclusão, fama, dinheiro, esforço, sorte, culto ao herói, salve-se quem puder, negação do sofrimento psicossocial, ficar com, cada um por si e Deus por todos.

O eixo principal a ser abordado será mais especificamente a vigilância, a fama e o confinamento, uma vez que estas características conferem o caráter inédito do programa e ficam em maior evidência para o telespectador.

\section{Vigilância}

A pergunta que se faz é: o que ocorreu, para que saíssemos do horror da vigilância, para imergirmos na apoteose voyerista, de contemplar supostamente em tempo integral, um grupo de indivíduos exibicionistas confinadas em um espaço marcado por câmeras e microfones?

A melhor forma de implantar o horror é vesti-lo, mascará-lo para que, glamourizado pelo poder hegemônico, seduza através da indústria cultural, indivíduos que se conformem às leis de mercado e à vigilância.

O controle, na sociedade contemporânea, é exercido de modo glamourizado pela Indústria Cultural. Assim, substituiu-se a guilhotina e a violência física por técnicas de controle social formadas dentro das ciências humanas e sociais, pela psicologia, psiquiatria e mais recentemente, pelos meios de comunicação de massa (Guinsberg (1991), Costa (1984) e Foucault (1983). No lugar de usar a força física para fazer corpos indóceis padecerem em razão de não se ajustarem, o que ocorre é a internalização através de uma intimidação ideológica exercida pelos meios de comunicação de massa, que produzem uma certa forma de ser, de viver, de pensar e de sentir.

A estratégia atual é constituir subjetividades, de forma que estas se enquadrem no modo de vida oferecido pelo social, pois de acordo com o filósofo francês Michel Foucault (1983), o poder moderno se exerce na produção e na repressão. Isto confirma o pensamento do pesquisador Costa (1984), quando discorre sobre a violência simbólica, em que os indivíduos encontram-se submetidos na ideologia da sociedade de consumo da atualidade.

Hoje, os vigias do "Grande Irmão", são todos os indivíduos, que auxiliado pela edição da mídia, ficam extasiados, fascinados diante da televisão, vigiando e controlando através de votos (programa interativo), os passos dos 12 participantes anônimos. O que, antes era temido - o controle e o vigiar - e também o que era protegido - a privacidade e a intimidade tornaram-se objetos de fascínio. Isto se evidencia no primeiro imperativo para participar do show de realidade — big brother — que é a imposição de restrição do privado. Oferece-se aos participantes uma casa bem equipada com 24 horas por dia de vigilância para que se tornem famosos, todavia, caso sejam excluídos e não ganhem o prêmio máximo de 500 mil reais, já tiveram a oportunidade de conquistar a fama. Troca-se desta maneira, a privacidade pela fama.

Acrescenta-se, que a sociedade contemporânea é descrita por Debord (1994), como a sociedade do espetáculo, que substitui o lema: "Penso, logo existo", por um outro ditado: "Sou visto, logo existo", Quinet (2002). Ainda segundo este autor, é a sociedade dominada pelo olhar, que é onividente sob diversas formas, que vão desde a proliferação dos programas televisivos de voyerismo e exibicionismo explícitos, até a difusão epidêmica da vigilância, que multiplicam as câmeras encontradas a cada passo do indivíduo. Vive-se hoje, numa sociedade escópica que tem como espetáculo, a disciplina e o controle. O olho que vigia e pune, é o mesmo que possibilita a fama. A visibilidade na atual sociedade de consumo sobre valoriza o mercado. Coelho (1999) ao discorrer sobre fama cita uma frase do filme Nasce Uma Estrela: "Você conseguiu mais do que queria. Mais fama, mas também, mais infelicidade pessoal" (p.49). A fama parece inseparável de um outro vínculo, a dor de ter que se separar do privado, de sua vida rotineira para se lançar rumo à ser objeto do olhar do outro, desgarrado e desenraizado de sua forma de ser.

Esta sociedade escópica impõe uma existência vinculada à visibilidade e consequentemente à celebridade, mas por outro lado, amplia cada vez mais a vigilância e o controle sobre cada indivíduo. Não é mais 
possível sair de casa sem se deparar com os dizeres "sorria você está sendo filmado". Verdade ou mentira, não importa, pois a frase faz existir um olhar invisível pousado no indivíduo. A instância desse olhar atribuído ao outro, é chamada por Freud de superego, que tem como um dos seus atributos, vigiar e punir o indivíduo. A sociedade escópica, ao utilizar esta estrutura subjetiva, multiplica seus dispositivos de vigilância eletrônica e transforma a todos, em objetos vistos' e controláveis. A Transparência, vira um ideal. Ainda, de acordo com Foucault, em "Vigiar e Punir" (1983), o panóptico (prédio circular com uma torre central) idealizado para melhor vigiar os prisioneiros, é o modelo de nossa sociedade disciplinar, em que os indivíduos são tornados transparentes para um "olho invisível”.

\section{Confinamento}

A vida se converte em ideologia da reificação. E, a rigor em máscara mortuária (Adorno, 1986, p.87).

Um dos meios utilizados pela mídia para apresentar o programa "Big Brother" como um show de realidade, é afirmar que o confinamento deve traduzir sentimentos verdadeiros, pois não dá para protelar nem para recalcar emoções ou indisposições com os companheiros de cela. $\mathrm{Na}$ verdade, o confinamento sob esta perspectiva mantém uma tensão. De um ângulo, poderia ser considerado um grande embuste, pois como consta nas regras do programa os participantes são vigiados 24 horas por dia. Como nos diz Sodré (1994), "as pessoas uma vez observadas pela câmera começam a fazer poses, construindo um real próprio encenado" (p.36). A partir desta frase, o real próprio encenado pode ser entendido como idealizado. Portanto, de outro ângulo, o desejo pela fama, entendido a partir do conceito elaborado por Coelho (1999), "como a construção da auto imagem pela projeção de uma imagem para os outros", já produz uma amputação da subjetividade, trazendo como um dos resultados, o impedimento de acionar instâncias psíquicas superiores. Desta forma, a razão é substituída pela fama. Para confirmar, nas palavras de Debord (1994):

A primeira fase da dominação da economia sobre a vida social acarretou, no modo de definir toda realização humana, uma evidente degradação do ser para o ter. A fase atual, em que a vida social está totalmente tomada pelos resultados acumulados da economia, leva a um deslizamento generalizado do ter para o parecer, do que todo ter efetivo deve extrair seu prestígio imediato e sua função última. Ao mesmo tempo, toda realidade individual tornou-se social, diretamente dependente da força social moldada por ela. Só lhe é permitido aparecer naquilo que ela não é (aforismo 17, p.18).

Assim, o que se mostra, não é fingimento ou teatro, pois a subjetividade sem a restrição da lei, basta para conformar-se às regras impostas pelo programa e representar sua identidade ideal, já capturada e ávida pela fama. Portanto, a vigilância já é um confinamento que determina uma forma de ser, uma vez que, sob vigilância, no palco, com os holofotes que potencializam a fama, há a transmutação de um ser pensante para um ser da imagem. É bom lembrar, que a situação dos participantes dos realities shows, expostos a uma câmera 24 horas por dia e cientes de que sua performance vai desembocar na sua exclusão ou permanência, tanto pelos seus parceiros como pelos telespectadores, são os elementos que confirmam a prisão do ser.

A seguir será apresentada uma listagem de privações provenientes do confinamento/vigilância, pré-requisito do programa Big Brother: de ir e vir; do cigarro, já que recebiam uma cota diária, previamente definida com os participantes que não poderia ser alterada durante o programa; da comida, a cada semana havia a prova da comida e em algumas não obtiveram sucesso recebendo apenas $1 / 2$ kit de alimentação e em uma semana especificamente passaram apenas com arroz, doce de leite e sal; da família; dos amigos; do banho privativo; do sexo; do estudo; do trabalho; do sono; dos meios de comunicação; de assistir a Copa do Mundo (julho/2002).

Com isto, observa-se, que inexiste a autodeterminação dos participantes, sendo que o controle/comando vem através da direção do programa e dos pares, no que concerne a escolha de quem vai ser indicado para o paredão. Este controle/comando, também vem dos telespectadores, que são os juízes, os quais decidem quem é eliminado da casa a cada semana.

Para Freud (1981) o ser humano é o ser da impotência e do desamparo. É um animal que para sobreviver e diferenciar o seu "eu" do "não eu" precisa da presença de um outro, principalmente, para desenvolver posterior interrelações em grupo e ao mesmo tempo preservar sua integridade individual (eu — não eu). 
Freud, ainda neste texto, menciona a existência de um sentimento oceânico, no qual o bebê, não é capaz de distinguir-se do mundo exterior, um "Sentimiento que lhe agradará designar 'sensacion de eternidad' , um sentimiento como de algo sin limites ni barreras" (p.3017). No desenvolvimento do indivíduo, no sentido da construção de sua individualidade/autonomia, a separação é uma árdua tarefa, que inclui a dor da renúncia. A renúncia à ilusão de fusão com o outro, de satisfação constante e absoluta e de um mundo sem perdas. Quando não ocorre esta separação, aquele sentimento oceânico domina, metaforicamente falando, todos os espaços e mantêm um sentimento de fusão com o outro, típico do vínculo simbiótico do bebê com a mãe. Freud cita ainda, a viabilidade do adulto também se encontrar em condições regressivas semelhantes àquelas vivenciadas pelo bebê.

O programa Big Brother não se constrange em fundir a vida com espetáculo (Quinet, 2002), transformando os participantes em celebridades, tornando-os famosos. Esta fama só pode ser conquistada pela potência tecnológica da mídia, independendo dos atributos subjetivos de cada participante, pois estes foram banalizados pela proposta do programa, que foi organizado sob as bases da vigilância, do confinamento, da exclusão, da fama e do dinheiro. Assim, o produto apresentado para o telespectador é um show que já não é de realidade. O script do programa gera um vazio, onde é colocada a fama. Uma das propostas do programa é a de transformar a privacidade em espetáculo. Importante observar, que o apresentado na tela, não é a privacidade nua e crua de ninguém, pois a direção do programa seleciona alguns fragmentos de seu interesse. A partir disto, a intimidade é construída com músicas de fundo que sublinham ou criam climas, maquiados com lentes inusitadas que transformam o banal em inusitado. A intimidade exposta, é limitada não só pelas mudanças de comportamento já produzidos, via mudanças de valores da sociedade espetacular, regida pelos princípios do mercado, pelas regras do programa, como também pelos recursos da mídia. Assim, estes programas produzem uma nova experiência da fama, que transcende uma expressão artística e é sustentada pela própria mídia. Portanto, o espetáculo é a própria mídia.

Com isso, pode-se compreender a fama com o conceito de prótese oferecido por Freud (1930):
El hombre ha llegado a ser, por así decirlo, un dios con prótesis: bastante magnífico cuando se coloca todos sus artefactos, pero éstos no crecen de su cuerpo y a veces aun le procuran muchos sinsabores (p.3034).

Compreende-se assim, a fama como uma prótese que substitui parte do corpo humano que está morta.

Pode-se coadunar a este fato, o estado regressivo no qual os indivíduos se encontram na cultura atual (Adorno, 1986; Caniato, 1997), que propicia a fusão do indivíduo com a fama, onde esta vem substituir uma parte do humano. E assim, pode-se concluir que a possibilidade de felicidade oferecida a estas pessoas é o uso de uma prótese que vem substituir os atributos inerentes ao humano, neste caso, a fama.

Ainda em Freud (1981) temos: "Pero que olvidemos, en interes de nuestro estudio, que tampoco el hombre de hoy se siente feliz em su semejanza com Dios" (p.3034), onde fica claro a ilusão e a perversidade de tudo isso, já que essas pró teses não pertencem verdadeiramente ao indivíduo e não podem lhe trazer a felicidade.

Em um depoimento, o sociólogo italiano Domenico de Masi (Veja, março 2002) declara que "o único verdadeiro beneficiado é o empreendedor da televisão, o sistema midiático". Descreve ainda, como um participante italiano de um reality show caiu em depressão depois de viver "uma fase de assédio incrível" e esquecer-se de que na verdade não era nada além de um produto descartável, artificial. A depressão foi desencadeada em nome da paixão obstinada pela fama que depois de um período esvaneceu-se. Assim o participante que teria feito um investimento libidinoso excessivo na fama, com o declínio desta, "é preso na contínua mistura de fantasia e realidade" (Coelho, 1999, p.49).

Os participantes entram no programa anônimos e saem famosos, porém, esvaziados de sua subjetividade, pois aprisionado o desejo; fica a imagem e o estilo de vida editado pelo programa. Os participantes tornamse próteses e celebridades, reduzidos a objetos de fofoca, bisbilhotagem, torcida e apostas. Tornam-se também, garotos propaganda com cachês baixos, mais sobre a égide de uma ilusão, pois de fato a fama aqui é passageira, descartável e efêmera como é a proposta do mercado do 
consumo. Pode-se acrescentar, para melhor elucidação, os dizeres de Debord (1994, aforismo 30, p.24):

A alienação do expectador em favor do objeto contemplado (o que resulta da sua própria atividade inconsciente) se expressa assim: quanto mais ele contempla, menos vive; quanto mais aceita reconhecer-se nas imagens dominantes da necessidade, menos compreende sua própria existência e seu próprio desejo. Em relação ao homem que age, a exterioridade do espetáculo aparece no fato de seus próprios gestos já não serem seus, mas de um outro que os representa por ele. É por isso que o espectador não se sente em casa em lugar algum, pois o espetáculo está em toda parte.

Por fim, esse trabalho traz uma descrição das características da subjetividade desejada, difundidas pelo programa através de seus participantes, principalmente do vencedor, que padroniza um modelo de ser na cultura atual. $\mathrm{O}$ vencedor é aquele que perde a intimidade e a identidade; aquele que se afasta dos seus e submete-se a uma experiência de "prisãoshow"; é julgado e sentenciado a cada comportamento e apresenta maior tolerância à privação. Enfim, aquele que muito perde e no final é referenciado como vitorioso.

\section{Subjetividade do vencedor}

Como já ficou claro no processo de seleção dos participantes, o modelo identificatório não é um indivíduo real, mas uma imagem forjada pela Rede Globo. Em outras palavras, não é que ela cria, mas sim, que ela escolhe previamente a imagem que atende às suas expectativas, pois quando a emissora citada, utiliza "olheiros" que procuram e indicam a imagem de um caubói, entende-se que a sua atenção não é com a constituição psíquica ou com os elementos da sua subjetividade, é com a sua fotografia-imagem. Somando-se ainda a estas contingências, temos os elementos já discorridos, tais como, confinamento, vigilância, exclusão e fama.

A intenção deste trabalho não é a de criticar ou censurar os participantes por terem aderido a este tipo de programa e sim, fazer uma análise de algumas características valorativas, impregnadas/imantadas de ideologia, já internalizadas pelos participantes. Entende-se que quanto mais se avança no estudo, tanto melhor se compreende que aqueles que dele participaram, são tão manipulados - via industria cultural — quanto manipuladores, conforme o conceito de cumplicidade discorrida por Adorno.

Ressalta-se, que a análise do programa foi efetuada a partir de um olhar crítico/investigativo sobre as edições veiculadas pela Rede Globo. Para tanto, utilizou-se como referencial teórico a psicanálise, uma vez que esta possibilita o acesso ao inconsciente, via atos falhos, mecanismos de defesa, chistes e atitudes que não se podem mascarar por um tempo indeterminado. Estes elementos são realidades psíquicas, que já capturadas por um modo de ser, interpõem-se nas relações interpessoais e no modo de ver e pensar o mundo. Estes são subsídios ricos para se pensar quais são os valores vivenciados a partir de uma sedução da sociedade de consumo, através da ideologia veiculada pela Indústria Cultural, via direção do programa e que, ao mesmo tempo, visa seduzir, conquistar novos adeptos a partir do telespectador, a um modo de ser.

A mídia tem como propósito, segundo Munoz (2002), criar mentalidades que se integrem à ideologia do sistema da sociedade de consumo. Para tanto, é necessário construir subjetividades que reiterem a fusão simbiótica e a não individuação, bem como, a destruição do laço social entre os diferentes para se tornarem facilmente capturados pela publicidade. Para conseguir isso, ela se utiliza dos modelos identificatórios.

A seguir serão descritas algumas características da subjetividade do vencedor - Caubói Rodrigo, as quais coadunam com os requisitos desta sociedade de consumo e espetáculo: Estrategista: (25/05- Rodrigo faz voto estratégico e manda Tarci para o paredão, 08/07- Rodrigo diz que sua estratégia tem 3 etapas, 13/07 - Rodrigo indica Tyrso: "Ele é forte"). Omisso: (22/06 - Caubói não sabe explicar o lance com Thaís, 11/06Pedro Bial faz a seguinte pergunta: Quem você acha que sai hoje? Rodrigo: Não sei, não sei). Subserviente ao poder: (07/07- Rodrigo para Pedro Bial: "Se sabe que toda a hora que eu vou falar com você eu me engasgo."). Culto ao herói: (14/05- Mãe de Rodrigo diz que o filho "é duro na queda", 10/07- Rodrigo conversa com Cida: "Foi uma adrenalina, uma coisa diferente, só sei que eu gosto dessa sensação", 16/07- Pedro Bial no programa ao vivo: "Vamos falar sobre o nosso líder Rodrigo, solitário como um coiote. O nosso caubói foi atravessando as semanas, ouvindo mais do que falando e quem diria chegou até aqui, bem pertinho da grande final".). Indiferente/não cria vínculos: (13/07 - Pedro Bial pergunta se Rodrigo 
tomou a decisão com a cabeça ou com o coração e ele responde: "Mais com a cabeça, certo? Porque no estágio que a gente está aqui só nós quatro, o coração, acho que pra gente não funciona muito, (...) a gente tem que usar uma estratégia de uma forma que mais para frente eu possa ter mais chance"). Individualista: (21/05- Rodrigo: "Cada um lava seu prato"). Plástico: (18/05- Rodrigo faz strip-tease, 28/05- Rodrigo no confessionário ao ser questionado sobre o comportamento de Thaís: "Eu encaro numa boa também, apesar de ser chucro desse tanto eu sou até mais ou menos moderno").

Concluindo, neste momento histórico assiste-se o emergir de uma nova geração, cujos indivíduos não se constituem a partir de identificações com figuras, estilos e práticas de velhas tradições, que definiam a cultura e sim, a partir de um ideal de estilo de vida propiciado pelos signos de consumo, objeto idealizado na sociedade contemporânea. Assim, o indivíduo desta nova geração está dotado, de acordo com Martin-Barbeto

(...) de uma plasticidade neuronal e elasticidade cultural que, embora se assemelhe a uma falta de forma, é mais abertura a formas muito diversas, camaleônica adaptação aos mais diversos contextos (2001, p.49).

Neste sentido, o modelo identificatório desejado e espelhado pelo poder hegemônico através da mídia/TV, é o do indivíduo desmemoriado que vive o eterno presente. É o indivíduo do aqui e agora, da indiferença, da omissão, do culto ao herói, do salve-se quem puder. Enfim, o indivíduo plástico que se adapta a tudo sem questionar. Não é o sujeito comprometido com o seu desejo, que aceita a falta e o conflito como constitutivos da condição humana, nem o sujeito histórico que tem passado e projetos futuros e que se enlaça no tecido social com os outros. Em outras palavras, não é o sujeito solidário, da cooperação e do compromisso consigo próprio e com os outros.

\section{Referências}

Barbero, J. M, REY, G. (2001). Os exercícios do ver: hegemonia audiovisual e ficção televisa. São Paulo: SENAC.

Bordenave, J E. D. (1982). O que é comunicação. São Paulo: Brasiliense.
Caniato, AM.P. (1999). A subjetividade na contemporaneidade: da estandartização dos indivíduos ao personalismo narcísico. Cidadania e Participação Social. Porto Alegre: ABRAPSOSUL, p.13-29 .

(1995). A história negada. Violência e Cidadania sob um enfoque psicopolítico. São Paulo. Tese de Doutorado apresentada no Instituto de Psicologia da USP.

Coelho, M. C. (1999). A experiência da Fama. Rio de Janeiro: F.G.V.

Cohn, G.(org.) (1986). Theodor W. Adorno. São Paulo: Ática.

Costa, J.F. (1984). Violência e Psicanálise. Rio de Janeiro: Graal.

Debord, Guy. A sociedade do espetáculo - Comentários sobre a sociedade do espetáculo. Rio de Janeiro, Contraponto, 1994.

Freud. S. (1981). El Malestar em La Cultura. Obras Completas. Tomo III. Madrid: Biblioteca Nueva, p.3018-3067.

Freud, S. (1969). Psicologia de Grupo e Análise do Ego. Obras Completas. Volume XVIII. Rio de Janeiro: Imago, p.89-179.

Focault, F. (1983). Vigiar e Punir. Petrópolis: Vozes.

Guareschi, P. A (1987). Comunicação e poder. $13^{\mathrm{a}}$ ed. Petrópolis: Vozes.

Guareschi, P. A (2000). Os construtores da informação. Petrópolis: Vozes.

Laplanche e Pontalis (2001). Vocabulário de Psicanálise. São Paulo: Martins Fontes.

Kristeva, J. (2002). As novas doenças da alma. Rio de Janeiro: Rocco.

Lipovetsky, G. (1983). A era do Vazio: ensaio sobre o individualismo contemporâneo. Lisboa: Antropos.

Quinet, A. (2002). Um olhar a mais: ver e ser visto na psicanálise. Rio de Janeiro: Jorge Zahar.

Ramonet, L (1999). Geopolítica da fé. Folha de S.Paulo. São Paulo. Folha Especial p.2 -26.

(2000). Nova economia. Palavração - Revista de Psicanálise. Curitiba: Biblioteca Freudiana de Curitiba, ano 4, n.4, p.114-117, novo 2000. [Questões da Contemporaneidade]. 
Sodre, M. (1984). A máquina de Narciso. Televisão, indivíduo e poder no Brasil. São Paulo: Cortez.

Thompson, J.B. (1998). A mídia e a modernidade. Petrópolis: Vozes.

Zenidarci, A. (2002). Câmeras e curiosidade: e hora do show. Viver. São Paulo: Comportamento, p. $34-36$.
A ética na escuta psicológica: o atendimento inicial e a fila de espera

Carmen L. O. O. Moré

Aline Rössel

Naiane Carvalho Wendt

Vanessa Silva Cardoso ${ }^{2}$

\section{Introdução}

$\mathrm{O}$ aumento da demanda por atendimento psicológico, os novos contextos e realidades que hoje se impõem à Psicologia, exigem um necessário e imprescindível redirecionamento das reais possibilidades de atendimento, no sentido da busca da eficácia e contextualização das ações de intervenção, principalmente nas instituições público-comunitárias e/ou de atendimento gratuito à comunidade.

A finalidade desse redirecionamento é o de gerar condições para uma "escuta do outro" na sua alteridade, visando acolher as necessidades das pessoas de forma contextualizada, evitando assim, situações que se situam diretamente no campo da ética, no sentido de abrir demandas psicológicas pessoais que não as solicitadas.

$\mathrm{O}$ crescimento da procura por atendimento psicológico, tanto em clínicas-escolas das instituições de ensino no Brasil, assim como no serviço público (postos de saúde, NAPS, CAPS), tem trazido à tona uma realidade de atuação para o psicólogo, que implica uma necessária reflexão dos parâmetros que sustentam o campo da produção científica, não somente na área da Psicologia Clínica, mas da Ciência Psicológica em si. A este respeito Moré (2000), tendo como referência seu trabalho de atuação em comunidades, afirma:

Assim, os aspectos epistemológicos, teórico-metodológicos e a dimensão ética neles presentes, são níveis de análise que desafiam a problemática de estar repensando o fazer da Psicologia e as dificuldades que surgem da necessidade de satisfazer à demanda, de um modo mais contextualizado e eficiente (p.3).

${ }^{1}$ Prof. Dr ${ }^{\mathrm{a}}$. Carmen L. O. O. Moré. Departamento de Psicologia - CFH - Universidade Federal de Santa Catarina.

${ }^{2}$ Acadêmicas de $10^{\mathrm{a}}$ fase do Curso de Psicologia - UFSC. 
A autora acima, também chama a atenção para o contexto de atuação do psicólogo, como um campo de possibilidades para ressignificar as práticas, no sentido que os contextos se configuram como um caminho que leva à construção de leituras diferentes e possíveis, dimensionando e enriquecendo a prática psicológica.

Especificamente no contexto da clínica-escola, aspectos em comum são apontados pela literatura de um modo geral, tais como, a inadequação dos modelos teórico-metodológicos às características das demandas específicas, falta de recursos humanos e materiais para atender ao aumento da demanda. Consequentemente, hoje a possibilidade de se conseguir um espaço de escuta nesses locais, é através de um atendimento inicial para depois enfrentar filas para tratamento, que podem levar aproximadamente um ano ou mais de espera.

O questionamento que surge é: Como pensar a ética nessas condições? Como se constituir como sujeito ético, diante dessas realidades que se desenham no nosso campo de atuação? Como responder a estes questionamentos? Ou em outros termos, para que serve pensar na ética em condições de atuação que não sustentam a conservação da saúde?

Isto nos remete diretamente ao nosso Código de Ética e a seus princípios fundamentais, II; III e IV, nos quais se afirma que o psicólogo baseia seu trabalho no respeito à dignidade humana do indivíduo como pessoa e procurará sempre promover o bem estar das pessoas, devendo sempre desenvolver "o sentido de sua responsabilidade profissional através de seu aperfeiçoamento científico” (p.3).

Assim, entendemos a ética como uma prática e exercício de reflexão constante a respeito das nossas ações e não simplesmente uma teoria que alude a um conjunto de preceitos, para evitarmos cair em situações de desconfirmação do sofrimento psíquico das pessoas que solicitam ajuda, pela primeira vez, mobilizando demandas que passarão por um longo momento de espera até que possam ser acolhidas novamente.

Acreditamos que pensar a partir do campo da ética é, de certo modo, superarmos o campo das habilidades técnicas e abrirmos um espaço para esclarecer o que está implícito em nossos fazeres, oferecendo elementos de análises que nos auxiliariam a elucidar qual é a nossa posição, enquanto agentes de saúde, em termos das escolhas que fazemos para nortear nossa atuação.

A ciência hoje nos desafia a aceitar e trabalhar na produção de conhecimento nas dimensões da complexidade, da imprevisibilidade e da intersubjetividade. Isto significa a superação dos antagonismos e diferenças, aspectos muito presentes na visão tradicional das ciências e do reconhecimento de que a realidade é de fato construída ou constituída pelo observador e pelas escolhas que este faz. Com relação a isto o pensamento de Vasconcellos (1995) sintetiza, no nosso entender, as reflexões teóricas relacionadas aos questionamentos sobre a ciência contemporânea e os novos delineamentos paradigmáticos:

Essa ideia de escolha se associa então ao princípio da complementaridade - com a crença subjacente de que a realidade é demasiado rica, cheia de relevos complexos e que um só projetor não poderia iluminá-la em sua totalidade (...) o conhecimento surge das distinções que o observador faz, e é este, pois, que constitui a realidade. A realidade só existe a partir da pergunta do observador sobre ela. A atividade científica consistirá em tentar responder a essa pergunta (p.65).

Assim, inseridos nesse olhar novo-paradigmático que aponta na direção de uma intervenção ancorada nas vozes do contexto, no intuito de captar a complexidade das situações humanas; este trabalho visa analisar a questão das filas de espera nas instituições de ensino superior, visando provocar ou incitar a reflexão em torno do conjunto de aspectos que convergem no campo da intervenção psicológica e de nossos modelos de atuação, objetivando a ressignificação dos mesmos à luz das realidades atendidas.

\section{Fundamentação teórica}

Assistimos hoje na cultura contemporânea a presença da pluralidade, a diversidade de eixos problemáticos, a necessidade de articular as diferenças, diante de uma realidade em que a complexidade é a marca predominante. De certa forma assistimos ao término da visão determinista, linear, homogênea, presente na visão tradicional, dando lugar a um tempo de dúvida e descontinuidade das ações, além da necessidade de diálogo na busca de um sentido em comum, com as realidades em que vivemos. 
Fuks (1992) nos chama atenção para a possibilidade de ressignificação das nossas interrogações, surpresas e incertezas decorrentes da prática, afirmando:

Na ruptura da coerência entre nossas teorias e nosso 'encaixe' com as realidades das quais somos parte é onde se nota a insuficiência das fórmulas aprendidas. É nessas bifurcações que recriamos a matriz para a criação de mapas/territórios (p.8).

Esta possibilidade de questionar conceitos já instituídos e provocar a desconstrução de sua significação original nos coloca, inevitavelmente, no campo da ética, no sentido da responsabilidade pelas escolhas que fazemos e, concomitantemente, pelas novas construções que favorecemos na prática cotidiana profissional.

A este respeito Elkain (1996) afirma sobre a importância de respeitar a complexidade, sem que a multiplicidade de elementos em jogo paralise nossas intervenções e ao mesmo tempo, sobre a importância da ética, no sentido de que nós participamos na criação das realidades que experimentamos e, por conseguinte, somos responsáveis por elas (p.210).

Assim, ao falarmos de responsabilidades e escolhas diante das práticas, na produção científica no Brasil, na década de 80 , evidenciou-se no campo da pesquisa o surgimento de uma série de trabalhos cujos temas centrais giravam em torno da atuação da Psicologia em instituições públicas, centros comunitários e clínicas-escolas, que tentavam responder as interrogações e incertezas que esses novos espaços e demandas exigiam da ciência psicológica. A este respeito, Moré (2000) aponta um aspecto diferencial importante dessa produção:

a realidade empírica adquire um status de conhecimento, relativizando, assim, a verdade dos principais corpos teóricos que permeavam o campo psicológico (p.17).

Um marco inicial em termos de primeiros registros sobre as práticas de clínica-escolas foi o livro Psicologia e Instituição de Rosa Maria Macedo, publicado em 1984 e que reúne uma série de trabalhos de pesquisadores que evidenciam uma espécie de radiografia das preocupações diante das práticas psicológicas daquela década. Segundo a autora, essa necessidade constante de se repensar a atuação do psicólogo se faz sentir através dos problemas e dificuldades em satisfazer a demanda de atendimento psicológico em instituições. Larrabure (1984) por sua vez, destaca no seu trabalho que as clínicas-escolas, se situam como locais de fácil acesso às diferentes camadas sociais da população, por prestarem atendimento gratuito e serem reconhecidas como referências uma vez que, estão ligadas a instituições de ensino, dando respaldo aos profissionais que ali trabalham.

No que diz respeito, a proposta de intervenção nas clínicas-escolas, Ancona Lopes (1984) chama a atenção sobre a contradição presente nas mesmas, no sentido de que o serviço é oferecido à comunidade, porém, uma grande parte da clientela não é chamada ou é encaminhada para fora. Dentre os casos que são chamados, muitos desistem durante o atendimento sem explicar seus motivos, e raramente, as clínicas podem afirmar que realizaram um trabalho completo. Aponta-se também para a necessidade de se adaptar e desenvolver técnicas de atendimento que condizem com a realidade da população de nível socioeconômico baixo, já que é esta camada da sociedade a grande clientela das clínicas-escolas do país (p.52).

Complementando a autora acima, Larraburre (1982) aponta para um outro aspecto: muitos dos casos que chegam às clínicas-escolas são resultados de encaminhamentos vindos de outras instituições e, desta forma, os pacientes caracterizam-se por não estarem realmente motivados para o atendimento, já que muitas vezes não reconhecem sua necessidade e desconhecem a natureza do trabalho do psicólogo. Confirmando esses dados encontramos a pesquisa de Moré (1994), sobre a representação social do psicólogo em centros comunitários de saúde, que além da desinformação dos serviços especializados em psicologia, evidencia a confusão entre atividade do Psicólogo e sua associação com hospitais e a diferença entre psicólogo e psiquiatra. Neste sentido, faz-se necessário um maior esclarecimento do pedido do cliente, já que não raramente as pessoas permanecem nas filas aguardando por um atendimento, sem realmente saber o que lhes espera.

Desde um outro ângulo, que se soma aos aspectos acima apontados, cabe refletir sobre o ciclo vital das pessoas que procuram atendimento. É importante ser destacado, de acordo com Carter \& McGoldrick (2001) que existem alguns sintomas e disfunções que são características do funcionamento normal do ciclo de vida da família. Duque (1996) afirma que estes sintomas e disfunções podem ser marcados por: 
períodos de transição, de passagem, durante os quais o equilíbrio e a organização familiar são abalados. Estes períodos caracterizam-se por certas doses de conflitos e ansiedade provocados por abalos nas regras e padrões de funcionamento até então estabelecidos... podendo expressar suas dificuldades de passar de um estágio a outro (p.78).

Nesse sentido, acreditamos que o atendimento psicológico de cunho mais informativo, proporcionaria esclarecimento e o restabelecimento do momento do desenvolvimento em que a família se encontra, não precisando para isto, longos tempos de tratamento, conforme propostas presentes nos modelos tradicionais.

Com relação à clientela das clínicas-escolas, Silva (1984) destaca que populações de baixa renda têm peculiaridades em relação à procura de atendimento: 1) não têm o hábito de abordar processos internos, estando muito mais voltados para ação, dadas as condições adversas nas quais vivem; 2) apresentam dificuldade de expressão e compreensão a nível verbal intensificada, quando o tema aborda tais processos internos em função de sua carência cultural e quando em confronto com o discurso habitual do psicólogo 3) revelam-se pessoas conformistas que não acreditam na possibilidade de reformulação e na utilidade desta, bem como na busca de melhores condições pessoais também para si; 4) possuem pequena disponibilidade de tempo; e 5) apresentam fundamentalmente um aumento da passividade diante de uma classe social dominante representada pelo terapeuta (p.100).

Esse conjunto de aspectos, associado à postura de intervenção ancorada em modelos que não acompanharam o processo de transformações ou adaptações das propostas de tratamento psicológicas, tem como consequência um impacto direto na relação psicoterapêutica. Segundo Macedo (1984):

surgiram subculturas para as quais a ajuda psicológica tem ficado a cargo de psiquiatras e dos tratamentos medicamentosos oferecidos pela previdência social (...) Esse modelo tradicional tem levado a uma relação patronal psicólogo-paciente, que foge da essência da atitude clínica (p.14).

As consequências disto pode ser evidenciada no trabalho de Larrabure (1984), no qual aponta que as evasões são frequentes durante o tempo de espera, pois a maioria dos clientes passa por várias instituições, sem receberem um atendimento efetivo (p.66)

No que se refere aos modelos de intervenção específicos para os contextos público-comunitários ou clínicas-escolas encontram-se trabalhos efetivos que apontam para as linhas das terapias focais ou estratégicas, abordagem familiar, grupal, comunitária, tentando de certo modo, responder às lacunas da prática.

Um aspecto interessante a ser ressaltado e que abre caminhos para reflexão e ampliação do campo do conhecimento é apontado em artigo publicado de Krawulski e Molinos (2000) chamando a atenção que, apesar de ter trabalhos que sugerem a aplicação de formas alternativas de atendimento, deixa de ser discutida a necessidade de uma recepção ou triagem; embora mencionados estes procedimentos, os autores pesquisados não se atêm a descrever tais processos (p.108).

$\mathrm{Na}$ revisão de produção teórica relacionada às questões da triagem ou recepção de atendimento psicológico, a produção é muito pouca e os trabalhos encontrados estão associados à triagem psiquiátrica ou no campo da saúde pública, relacionados à enfermagem e mais especificamente às questões de acolhimento em centos de saúde.

No que diz respeito a modelos de intervenção psicológicos específicos tanto para clínica-escolas como para o atendimento comunitário, preocupados com a questão do acolhimento inicial e o aumento da demanda, entre os trabalhos mais recentes encontramos o Plantão Psicológico de Miguel Mahfoud (organizador) (1998), sendo que o mesmo se configurou em decorrência da constatação de um alto índice de desistência por parte da clientela que busca ajuda na instituição, frente às longas filas de espera para psicoterapia e também através da observação de que algumas pessoas procuram a clínica em situação de emergência (p.115). Segundo o autor, esta modalidade de Plantão Psicológico desvincula-se da ideia tradicional de psicoterapia a qual está atrelada ao pensamento de que quanto mais longo o processo, maior sua eficácia. Assim o Plantão Psicológico caracteriza-se por ser um atendimento psicológico do tipo emergencial, que visa atender de forma imediata a solicitação do cliente, sem a necessidade de agendamento, através de uma escuta diferenciada. 
Outra possibilidade de intervenção desenha-se na tese de doutorado de Carmen Moré (2000) na sua proposta de um modelo de sistematização de intervenção psicológica, junto a postos de saúde comunitários, evidenciando caminhos possíveis de serem incorporados às práticas clinicas já existentes, visando principalmente uma escuta inicial contextualizada e eficiente, para diferenciar qual a solicitação específica da queixa inicial. Ao falar de eficiência, a autora alude diretamente às possibilidades de um modelo de intervenção favorecer condições para todos os envolvidos na situação de atendimento, de serem co-construtores das possibilidades de mudanças e/ou tenham uma resposta para queixas, motivos da consulta.

Segundo Berlinguer (1996) a ciência é o campo, por excelência, em que a dimensão ética tem ressurgido com força total nos últimos anos. Assim, quando analisamos a produção teórica percebemos realmente, que repensar as práticas ancoradas nas teorias é um exercício constante da nossa profissão, principalmente hoje, ao aceitarmos a recursividade das nossas ações, na ressignificação das intervenções que realizamos. Associa-se a isto a complexidade de aspectos que precisam ser analisados e que saem do terreno meramente psicológico, em termos de habilidades técnicas para seu exercício. É nesta fronteira e interfaces com outros aspectos e áreas do conhecimento, que influenciam diretamente nossas intervenções, que a ética enquanto processo constante de reflexão, irrompe com força, no sentido de nos permitir ancorar nossas escolhas e possíveis certezas enquanto intervenção.

\section{O Serviço de Atendimento Psicológico da Universidade Federal de Santa Catarina (SAPSI)}

O SAPSI tem passado por inúmeras reestruturações desde sua criação em 1977. No início, atendia apenas a comunidade universitária, porém, aos poucos passou a estender seus serviços à comunidade em geral, "atingindo hoje não apenas o município de Florianópolis, mas também as cidades circunvizinhas" (Molinos e Krawulski, 2000; p.105). Este serviço abrangia a elaboração de psicodiagnósticos, seleção e orientação profissional, atendimento psicoterápico individual a adultos, adolescentes e crianças e atendimento psicoterápico grupal a adultos e adolescentes. Além disso, também passou a desenvolver pesquisas científicas na área do comportamento humano e a oferecer um campo para estágio e treinamento supervisionados aos estudantes de Psicologia.

O aumento da demanda no SAPSI exigiu o redirecionamento de suas atividades, com o propósito de um melhor acolhimento das necessidades da comunidade. Diante disso, em julho de 1996, Molinos e Krawulski psicólogas do Serviço, sugeriram adotar uma sistemática precisa de procedimentos através da implantação de um processo de triagem, com o objetivo de oferecer um atendimento preliminar à clientela que procurava 0 SAPSI, possibilitando a otimização do fluxo de atendimento psicológico prestado. Além disso, visava também: a) fornecer informações sobre a natureza, o funcionamento e as possibilidades de atendimento oferecidas pelo serviço; b) prover o devido encaminhamento para casos específicos, em que as modalidades de atendimento realizadas na clínica não os contemplassem; c) acolher a primeira demanda das pessoas por atendimento psicológico e d) reduzir o tempo de espera por atendimento (que chegava perto dos dois anos, conforme dados de pesquisa de Molinos e Krawulski, 2000). No entanto, após cinco anos da implantação do processo de triagem, o SAPSI ainda convive com as filas de espera, sendo este o "caminho natural" para receber atendimento psicológico no mesmo, de certa forma, volta-se novamente ao mesmo problema que originou a modificação da sistematização do acolhimento: a crescente fila de espera. Na análise desta problemática (Krawulski e Molinos (2000) apontam dificuldades presentes no serviço tais como:

pilhas de fichas preenchidas, telefones e endereços desatualizados, situações em que os estagiários têm horários disponíveis, mas deparam-se com a dificuldade para entrar em contato com os pacientes sendo que as pessoas ou famílias cadastradas permanecem à espera de atendimento por aproximadamente um ano (p.107).

Esses dados evidenciam claramente, aspectos presentes no campo de atuação que recursivamente afetam qualquer proposta de intervenção, tais como a questão da falta de recursos humanos, a questão das greves das universidades federais e uma melhor adequação dos projetos de estágio aos alunos enquanto formação.

Novamente, as realidades nos desafiam a pensar se é a falta de habilidades técnicas, que parece ser o grande foco em torno das qual se centram os esforços dos profissionais da psicologia, ou, outros aspectos que 
de forma recursiva afetam a eficiência do conhecimento psicológico em termos de atuação.

\section{Metodologia}

Foram selecionados para a amostra 26 casos que estavam na fila de espera do Serviço de Atendimento Psicológico da Universidade Federal de Santa Catarina, obedecendo aos seguintes critérios: 1) o tempo em fila de espera (6 meses em diante); 2) que nunca haviam sido chamados; 3) que foram encaminhados pela triagem para serem atendidos pelo serviço de atendimento psicológico infantil/familiar e 4) foram efetivamente acompanhados desde o momento do primeiro contato via telefone ou correspondência. A coleta foi realizada de fevereiro a setembro de 2002. Realizou-se análise qualitativa dos dados contidos na ficha de triagem e dos relatos trazidos pelos pacientes durante os primeiros contatos e/ou início do processo de intervenção psicológico, sendo os dados agrupados em torno de categorias.

\section{Caracterização dos participantes da amostra}

Em relação à renda familiar das famílias e/ou pessoas atendidas, cerca de $46 \%$ recebiam de 200,00 a 600,00 reais mensais. Considerando que a quantidade de pessoas por família era de 2 a 6 respectivamente. No que diz respeito à instrução, a maioria da amostra, tinha instrução primaria completa e incompleta, sendo que as solicitações de ajuda iniciais eram, na maior parte, figuras femininas (mães, tias ou avós).

\section{Análise e discussão dos resultados}

Os dados da pesquisa, transformados em gráficos para sua melhor visualização, evidenciam num primeiro momento o tempo em fila de espera da amostra pesquisada, sendo que, $84 \%$ da mesma distribuiu-se nos primeiros 13 meses. (Fig.1)
Figura 1 - Tempo em espera para o início do processo de intervenção terapêutica

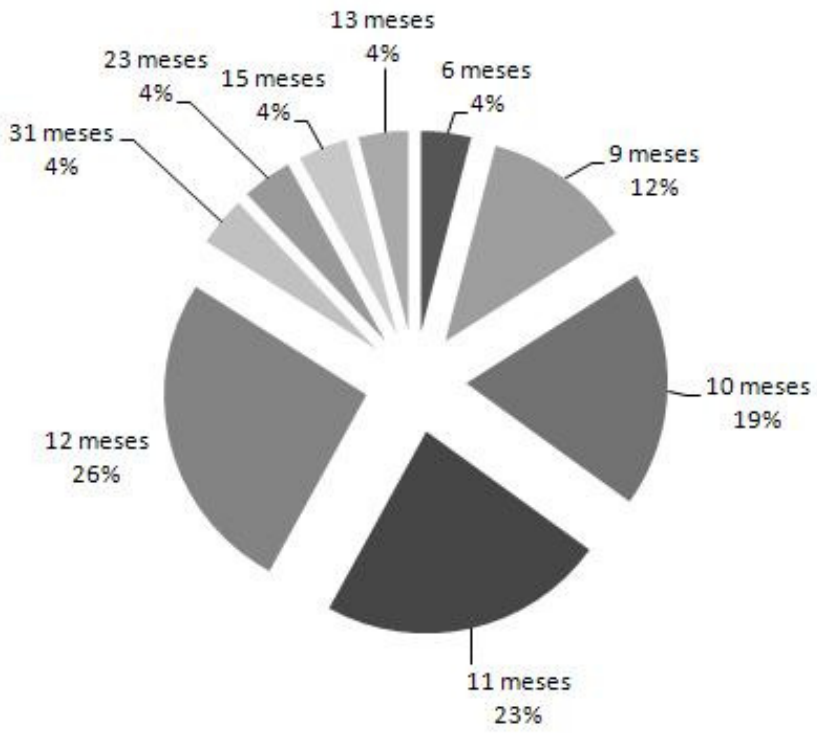

Ao entrarmos em contato, como os participantes da amostra, seja através de telefone, correspondência ou no início do processo psicoterapêutico, verificamos nos diálogos iniciais, antes de explicitar novamente a queixa principal ou a modificação da mesma, depoimentos que expressavam sentimentos de surpresa, certa ironia e até desconfirmação, presentes nos entrevistados, que de certa forma nos afetavam recursivamente, gerando uma sensação de desconforto ou constrangimento.

Para exemplificar esta análise destacamos frases dos participantes, que quando contatados via telefone, respondiam:

Ah! da universidade (...) Pensei que não iam me chamar mais (...)

$\mathrm{ou}$,

Não preciso mais, essa loucura já passou. Porque sabe, né? Pobre não tem depressão, fica louco, mais obrigada, né? 


\section{Ou então:}

Falei com a minha filha, ela diz que não quer ir, já fui atendida no hospital com ela e ela não quer mais.

Associadas a essas frases, encontram-se situações em que as pessoas aceitavam a ideia de iniciar o tratamento, porém, faltavam no primeiro encontro ou não retomavam o contato feito, para confirmar o novo atendimento, a fim de dar início de proposta de intervenção, conforme a nossa solicitação. Cabe apontar aqui também, que algumas pessoas relatavam que se sentiam aliviadas de suas angústias, após primeiro atendimento inicial, porém faltavam ao agendamento proposto. Isto nos levou a pensar em várias hipóteses, uma delas foi a diminuição da ansiedade e perda do interesse ou da motivação para a continuidade do atendimento e/ou desconhecimento da especificidade do trabalho terapêutico.

Acreditamos que esses dados deixaram em evidência de forma implícita os efeitos do impacto do tempo de espera nas pessoas, através de sentimentos que revelavam o sentir-se negligenciadas ou esquecidas da nossa oferta de serviços. Por outro lado, e de forma paradoxal, revelaram uma situação invertida, no que diz respeito à solicitação original. Ou seja, num primeiro momento as pessoas procuraram por ajuda e não foram acolhidas na dimensão que elas esperavam. De forma similar, quando nos entrávamos em contato para fazer nossa proposta de intervenção, não éramos acolhidos na forma que nós acreditávamos que poderíamos ser, gerando assim, sensações tanto de desconforto e insatisfação das nossas ações, como de questionamento da eficácia das mesmas, pelas consequências que constatávamos.

Do total da amostra, $28 \%$ (Fig. 2) aceitaram a proposta de dar inicio ao tratamento e continuaram até o final; $15 \%$ procurou ajuda psicológica em outras instituições; $42 \%$ não foram atendidos por declararam não terem mais interesse; impossibilidade de contato ou por não terem retomado o contato, via telefone ou correspondência; $15 \%$ iniciou o atendimento, abandonando antes do término do tratamento, caracterizando a desistência.

Estes dados por si, geraram questionamentos diretos sobre a escuta inicial e mais especificamente sobre qual o pedido explícito e implícito na queixa inicialmente trazida, levando a discussão sobre a necessidade, em termos teórico-técnicos de intervenção, de uma melhor adequação da escuta psicológica, quando da recepção do paciente/família, de acordo com as necessidades e características dos mesmos.

A importância da escuta inicial desenhou-se como um ponto de convergência dos dados, apontado já na literatura por Moré (2000) e foi no sentido de desvendar por exemplo, se as queixas iniciais eram do terreno exclusivamente psicológico, ou de necessidade de informação a respeito de problemas do cotidiano; ou de esclarecimentos de especificidades profissionais; ou de orientação, que se resumiu a uma consulta só, não havendo necessidade de retorno. Assim, percebemos que a ênfase na melhor discriminação torna a escuta inicial num instrumento estratégico de análise, auxiliando na definição da mesma e gerando propostas de intervenção condizentes com as necessidades das pessoas.

Figura 2 - Incidência dos casos

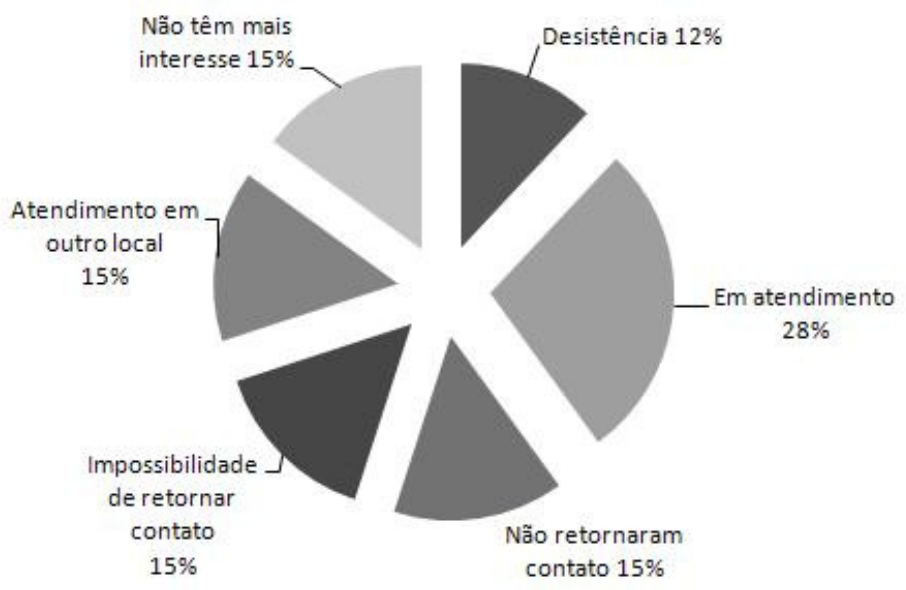

Constatamos também as características próprias da população que procura atendimento em espaços público-gratuitos e já apontadas na literatura (Larrabure, 1984; Macedo, 1984; Moré, 2002) tais como: dificuldades econômicas na luta pela sobrevivência, baixa escolaridade e de estar orientadas para a ação, adotando uma postura de submissão, negando seus próprios saberes e delegando as responsabilidades dos seus atos ao 
profissional e quando não encontra essas respostas prontas, a tendência é de desistir do tratamento. Esses dados necessitam ser mais bem explorados, para termos claro qual é o impacto dos mesmos no pedido inicial.

A evidência de maior porcentagem de queixas tidas como sociais, de acordo com nossa categorização, (Fig. 3) bem como, do significativo número de casos em que houve mudança ou desaparecimento da queixa, constatados ao entrarmos em contato com as pessoas após o tempo de espera, seja por telefone ou no primeiro encontro da proposta de intervenção, contribuiu para acreditarmos que o momento de vida em que a pessoa solicitante se encontrava ao procurar ajuda, sofreu alterações durante o tempo de espera, o que também veio a colaborar para a desistência inicial da proposta, ou para seu abandono logo após a mesma ter sido iniciada.

Figura 3 - Classificação das queixas iniciais apresentadas pelos sujeitos da amostra

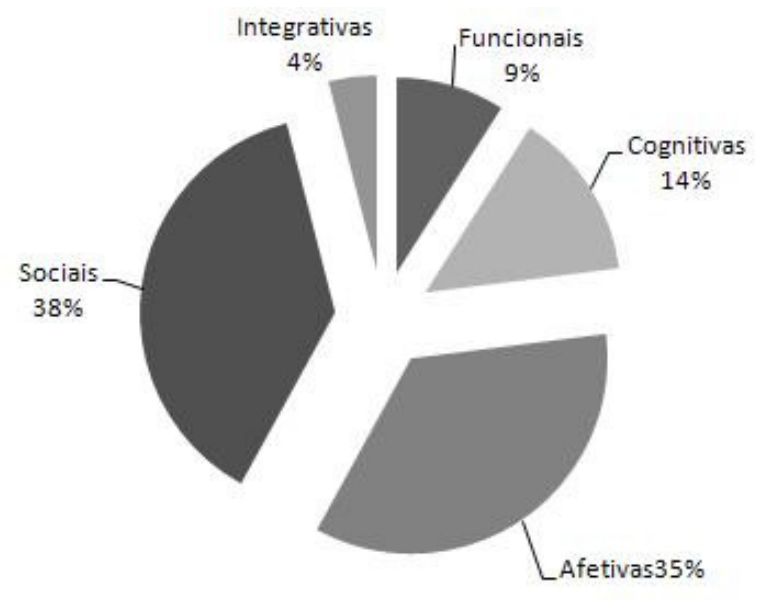

Os dados acima foram aspectos que influenciaram diretamente a construção da aliança terapêutica, base principal de nosso trabalho, tais como a desmotivação pelo desaparecimento ou mudança da queixa e a não compreensão e/ou desinteresse na proposta. Ou seja, evidenciou-se a perda do sentido da significação do pedido inicial, criando condições difíceis para a construção de um campo de sentido em comum das ações, tanto para as pessoas, como para nos proponentes da intervenção.

Para a análise das queixas iniciais, (Fig.3) no momento da triagem foram classificadas em categorias propostas por Anthony (1975). Dos casos acompanhados, $38 \%$ trouxeram queixas tidas como sociais, exemplificadas através de dificuldades de relacionamento, econômicas, sexuais, questões de gênero e trabalhistas. As queixas denominadas afetivas também tiveram uma frequência considerável, $35 \%$ do total. Nesta entraram comportamentos como temores, ansiedade, depressão-elação, vergonhaculpa e nojo. Na categoria das queixas de ordem cognitiva foram classificados comportamentos relacionados ao pensamento, à memória, aprendizagem, orientação e testes de realidade. A categoria funcional abarcou dificuldades relacionadas à alimentação, eliminação, sono, movimentação e fala. E por último, a categoria das queixas integrativas, onde o parco controle dos impulsos, baixa tolerância à frustração, rigidez-estereotipia, enfrentamento inadequado e desorganização foram considerados.

A importância da compreensão do ciclo vital das pessoas e as modificações da estrutura familiar foram elementos importantes que se configuraram a partir da análise da queixa inicial, através de suas categorias e as mudanças acontecidas. (Fig.4). Observamos modificações da estrutura familiar tais como: separação dos pais, a morte de um membro da família, a saída ou entrada de um membro na família. Essas mudanças no ciclo de vital, conforme apontado na literatura, Carter \& McGoldrick (2001); Duque, (1996) faziam parte do processo de desenvolvimento da estrutura familiar ao longo do tempo e que em determinados momentos as pessoas depararam-se com a necessidade de adaptação à nova configuração do sistema familiar. Assim, a análise estratégica da escuta inicial, conforme mencionado anteriormente, contextualizado no ciclo vital das pessoas, nos localizou no tipo de proposta a ser oferecida para as pessoas. Estes aspectos também corroboraram a possibilidade de um Plantão Psicológico, proposta por Mahfoud (1998). 
Figura 4 - Alterações da queixa inicial ao longo do tempo em espera

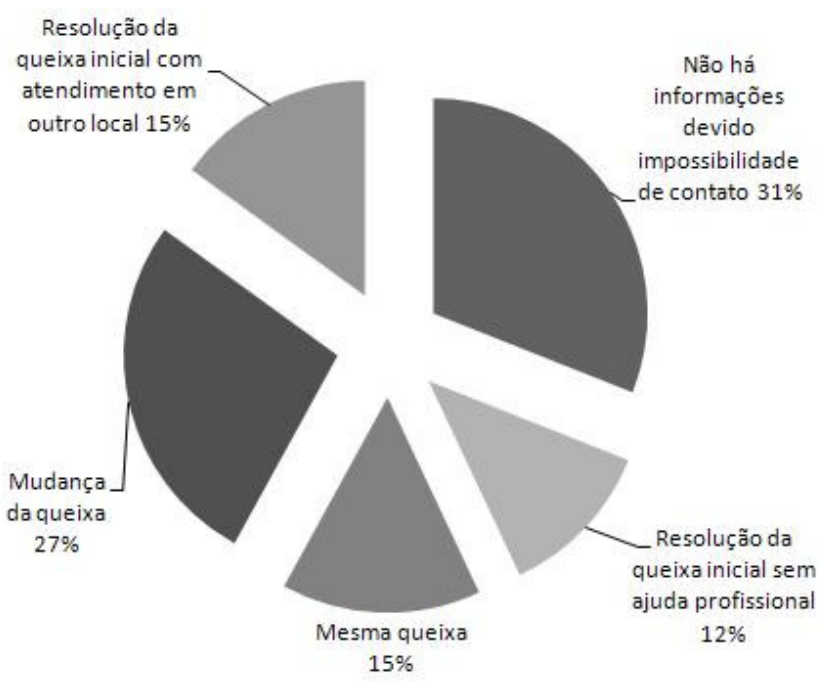

Discorremos até agora sobre aspectos significativos observados na pesquisa, no campo específico da intervenção psicológica, por ocasião da escuta inicial, tentando responder aos questionamentos das nossas intervenções, no entanto, não podemos deixar de mencionar o aspecto institucional, que estava permeando nossas ações, o qual tinha consequências diretas sobre as mesmas, enquanto propostas.

O SAPSI, embora tendo uma diversidade de proposta de projetos de ofertas de serviço à comunidade, convive com uma série de problemas de ordem institucional. Ao nível dos recursos humanos, destacamos a falta de reposição dos mesmos, pela não abertura de concursos seja de psicólogos, como de professores supervisores nas diversas áreas de oferta de serviços. Também as greves, que afetaram tanto a comunicação com a comunidade, assim como, geraram a interrupção nos processos em andamento, devido à falta de condições, em termos de local para atendimento. Do mesmo modo, evidenciamos que a quebras de calendário acadêmico, semestre após semestre, afetaram às intervenções atreladas aos estágios, quando as mesmas não eram bem planejadas ou articuladas entre professores, alunos e usuários e pela mudança de estagiários nos processos de intervenção. Acreditamos que estes aspectos afetavam a proposta de intervenção, gerando confusão na comunicação, incidindo na não compreensão das ações, levando por consequência à desistência. Em termos de local de atendimento convivemos com a falta de verbas para uma melhor adequação das salas de atendimento e diante da falta de materiais, recorríamos à improvisação e criatividade para gerar condições próximas a um atendimento adequado ao processo proposto.

Assim, observamos nesta pesquisa, a emergência de dados significativos que ampliaram as possibilidades de uma escuta inicial e que nós denominados de uma "escuta estratégica" no sentido de melhor acolher os dados, que de forma implícita ou explícita, estavam presentes no campo de intervenção, para assim poder ancorar nossas propostas. No processo constante de analisar nossas ações à luz das realidades atendidas, concordamos com Vasconcellos (1995) quando nos chama atenção do olhar da ciência contemporânea sobre a realidade, afirmando que a mesma é muito rica e diversa e que só um aspecto não poderia contemplá-la. A realidade, ao se revelar rica, complexa e exposta a mudanças exigiu atenção especial, no sentido de estarmos atentos ao que Elkain (1997), denominou de "perigo de cair na paralisia das ações", afetando a eficácia das mesmas, no que diz respeito a ficarmos presos à diversidade de aspectos que convergem na análise das nossas ações.

Assim, percebemos que os dados até aqui apontados, nos desafiam na complexidade de fatores que se afetam mutuamente, presentes no campo de intervenção psicológicos e às vezes difíceis de serem percebidos pelos profissionais. Observamos que, quando não analisados em seu conjunto, afetam diretamente qualquer proposta de intervenção psicológica, gerando situações como as da fila de espera, situação que no nosso entender é de real "desconfirmação do outro" na sua condição de ser humano que sofre e solicita ajuda para tal condição.

Entendemos que se faz necessário ampliar a discussão em torno das consequências da oferta de serviços psicológicos nos espaços públicos, que consideramos vai além, tanto dos modelos específicos de atendimento psicológico, como da qualidade dos serviços prestados à comunidade pelas clínicas-escolas.

Acreditamos que o campo da ética se constitui como um lugar de encontro dos diversos fatores que convergem nas nossas ações de 
intervenção, no sentido que favorece as escolhas que devemos fazer para melhor abordar as queixas das pessoas, contribui efetivamente para sermos cientes que a procura por respostas será um caminho árduo e constante e que devemos conviver e aceitar, em termos de desafio constante, as situações de desconforto e insatisfação que nossas ações nos provocam, sabendo e que nunca recolheremos perfeitamente a pluralidade das experiências em que estamos imersos.

Evidenciar o desconforto das consequências de nossos atos, significou aprender com o mesmo, para poder construir um fazer psicológico ancorado em princípios éticos que no nosso entender, caminha sempre no acolhimento de outro na sua alteridade, abrindo possibilidades efetivas, tanto para a promoção da saúde como para a manutenção da mesma.

\section{Considerações finais}

A partir dos dados do presente trabalho visualizamos algumas possibilidades de contribuição para uma maior agilidade de atendimento, assim como para a melhoria da qualidade dos serviços prestados à comunidade:

1. A necessidade de aumento dos recursos humanos, tanto de estagiários quanto de professores, supervisores e profissionais;

2. Treinamento específico dos recursos envolvidos para uma escuta mais focal e estratégica das queixas, seja ela ao nível individual, familiar e grupal;

3. Fomentar a realização de grupos terapêuticos; e

4. Realizar plantão psicológico para emergências e orientação.

Finalmente, acreditamos que a procura por respostas aos questionamentos das nossas práticas deve ser um compromisso ético, evitando assim, situações que se inserem diretamente no campo da ética da escuta do outro.

\section{Referências}

Ancona-Lopez, M. (1984). Atendimento psicológico em clínicas-escola. In: Macedo, R, (org). Psicologia e Instituição: Novas formas de atendimento. (p.47-61). São Paulo: Editora Cortez.

Anthony, E.J. (1975). Distúrbios de comportamento na infância. In: Mussen, P.H. Carmichael. Psicologia da Criança. São Paulo, EPUEDUSP.

Berlinguer, G. (1996). A ética da saúde. São Paulo: Hucitec.

Carter, B.; Mc Goldrick (1995). As mudanças do ciclo vital de vida familiar. Porto Alegre: Artes Médicas.

Código De Ética Profissional Dos Psicólogos. (2002). Conselho Federal de Psicologia.

Duque, D. (1996). Crises normais do ciclo de vida familiar. In: Revista $A B A G, \operatorname{vol} .5$ (p.78-86).

Elkain, M. (1996). Nos limites do enfoque sistêmico em psicoterapia. In: Novos paradigmas de cultura e subjetividade. (p.205-215). Porto Alegre. Artes Médicas.

Fuks, S. (1992). Cambio y complexidade em terapia. Trabalho apresentado no III Encontro nacional de terapeutas de famílias. Brasília.

Krawulski, E.; Molinos, B.G. (2000). Implantação de um processo de triagem no Serviço de Atendimento Psicológico da UFSC-SAPSI. In: Revista de Ciências Humanas, (p.103-115) Florianópolis: EDUFSC, n. 27.

Larraburre, S.A.L. (1984). Grupos de espera em Instituições. In: Macedo, R.S.M. (Org.) Psicologia e Instituição: Novas formas de atendimento. (p.63-84) São Paulo: Editora Cortez.

Macedo, R.S.M. (Org.) (1984). Psicologia e Instituição: Novas formas de atendimento. São Paulo: Editora Cortez.

Moré, C.L.O.O. (2000). Atendendo à demanda: proposta de um modelo de sistematização de intervenção psicológica junto a postos de saúde 
comunitários. Tese de Doutorado. Pontifícia Universidade Católica de São Paulo.

More, C.L.O.O. (2001). A Representação Social do Psicólogo e de sua prática no espaço público-comunitário. In: Paideia, 11(20), 85-98.

Silva, O. V. M. (1984). Grupo estruturado de vivência para pais. In: Macedo, R.S.M. (Org.) Psicologia e Instituição: Novas formas de atendimento. (p.99127). São Paulo: Editora Cortez.

\section{PSICOLOGIA E RELAÇÕES DE GÊNERO}

\section{A constituição do sujeito excluído catador de material reciclável e a construção da sua cidadania}

Daiani Barboza

Este artigo se propõe a analisar a constituição do sujeito excluído catador de material reciclável (M.R.) em Criciúma, no sul de Santa Catarina, buscando focalizar alguns aspectos acerca de seu movimento de impotência e/ou potência de ação na constituição da sua cidadania, temática tratada na minha pesquisa junto à linha de pesquisa "Práticas Sociais e Constituição do Sujeito" no Programa de Pós-Graduação em Psicologia Mestrado em Psicologia, da Universidade Federal de Santa Catarina UFSC. Cabe registrar que as reflexões apresentadas neste artigo pautam-se nos referenciais teóricos e metodológicos da Psicologia Social Comunitária Comunidade é entendida aqui sob a ótica de Sawaia (1997), sendo concebida

não como espaço físico, geográfico, ou étnico, mas como utopia. Espaço-tempo com qualidade de favorecimento do exercício de autonomia, onde as identidades tornam-se crioulas sem perder o sentido de si e do outro, para poder dispor de si para si e para o outro. (...) Ao se qualificar de comunitária a prática se volta à mediação entre a universalidade ético-humana e a singularidade do gozo individual e intersubjetivo e se propõe trabalhar o público no privado e o privado no público, bem como o pessoal como político e o político como pessoal (p.86).

Trazer como foco de análise a dimensão da constituição da subjetividade do sujeito excluído, considerando e contextualizando o processo dialético da exclusão/inclusão, significa contribuir no campo da Psicologia, com a construção de uma práxis pautada na ética e na emancipação humana. Baseia-se também na busca da construção de uma ciência comprometida com a realidade social e com as transformações socioculturais, pois, conforme Santos (1989/2000), é preciso construir uma

${ }^{1}$ Psicóloga, professora na UNESC e mestranda em Psicologia pela UFSC, junto a linha de pesquisa "Práticas Sociais e Constituição do Sujeito". 
ciência que se paute na linguagem do nosso cotidiano, que rompa com a dogmática da ciência positivista, dialogando com o mundo criticamente, com vistas a transformá-la. Segundo este autor, torna-se necessário

transformar a ciência, de um objeto estranho, distante e incomensurável com a nossa vida, num objeto familiar e próximo, que, não falando a língua de todos os dias, é capaz de nos comunicar as suas valências e os seus limites, os seus objetivos e o que realiza aquém e além deles, um objeto que, por falar, será mais adequadamente concebido numa relação eu-tu (a relação hermenêutica) do que numa relação eu-coisa (a relação epistemológica) e que, nessa medida, se transforma num parceiro da contemplação e da transformação do mundo. Compreender assim a ciência não é fundá-la dogmaticamente em qualquer dos princípios absoluto ou a priori... Ao contrário, trata-se de compreendê-la enquanto prática social de conhecimento, uma tarefa que vai cumprindo em diálogo com o mundo e que é afinal fundada nas vicissitudes, nas opressões e nas lutas que o compõem e a nós, acomodados ou revoltados (Santos, 2000; p.13).

Enfocar desta forma a temática da constituição do sujeito excluído implica romper com quaisquer concepções estáticas, dicotômicas, abstratas ou fetichizadoras acerca da exclusão e da constituição do sujeito. Portanto, torna-se fundamental compreender o processo histórico no qual a exclusão ocorre e quais as suas implicações nas relações que o sujeito constrói consigo mesmo e com os outros. Estudar seu movimento de enfrentamento da sua condição de exclusão ou de sua impotência para lutar na busca de formas de superação desta é de suma relevância para a Psicologia. Paugam (1999) em seus estudos sobre exclusão considera que a pobreza está sendo revestida de um status social estigmatizado e desvalorizado, sendo vítima de um processo de desqualificação social e vista como uma categoria homogênea, cuja concepção desconsidera a singularidade dos sujeitos e de suas histórias de vida. Para o autor,

toda definição estática da pobreza contribui para agrupar, num mesmo conjunto, populações cuja situação é heterogênea, ocultando a origem e os efeitos a longo prazo das dificuldades dos indivíduos e de suas famílias (p.68).

Dessa forma, conceber a heterogeneidade destes atores sociais é imprescindível nos estudos, nas pesquisas e nos diversos trabalhos com excluídos, pois do contrário se consideraria a pobreza meramente como estatística e/ou massa homogênea.

Cumpre dizer que meu trabalho de pesquisa junto aos catadores vem acontecendo concomitantemente com meu envolvimento no projeto Ação comunitária junto aos catadores de material reciclável — Desafios à construção da cidadania, da democracia e à inclusão social, desenvolvido interdisciplinarmente pelos departamentos de Administração, Direito, Engenharia Ambiental, Medicina, Psicologia e Cursos Sequências da Universidade do Extremo Sul Catarinense - UNESC, que é supervisionado pela sua Diretoria de Extensão e Ação Comunitária, no qual atuo na condição de coordenadora. O trabalho visa contribuir com a construção da cidadania dos catadores de material reciclável de Criciúma/SC em seus aspectos objetivos e subjetivos. Por meio da reconstituição de um processo cooperativo, mais especificamente, pretendese contribuir com melhorias nas condições de vida dos catadores de material reciclável. Para tanto, o projeto viabiliza a construção de espaços de encontro e diálogo junto aos catadores, fortalecendo os laços comunitários e enfatizando a ética, a democracia e a emancipação humana como referenciais fundamentais para a construção de uma cultura cooperativista. Evidencia-se o cotidiano como fundamental para a construção de outras formas de comunicação, pautadas no diálogo e na constituição de sujeitos abertos à alteridade, tendo em vista potencializá-los na busca por soluções para os problemas enfrentados. $\mathrm{O}$ trabalho desenvolvido está em consonância com as diretrizes do Movimento Nacional dos Catadores e o Programa Nacional "Lixo e Cidadania", desenvolvido por iniciativa do UNICEF e que se iniciou em junho de 1999 com a campanha "Criança no lixo, nunca mais", vinculada ao Fórum Nacional Lixo e Cidadania. O Programa Nacional "Lixo e Cidadania" tem por objetivo principal a erradicação do trabalho infantil, incentivando a organização dos catadores em associações e cooperativas, tendo em vista qualificá-las profissionalmente, bem como torná-las parceiros prioritários em programas municipais de coleta seletiva, o que facilitaria aos municípios a erradicação dos lixões e a recuperação ambiental das áreas degradadas (Abreu, 2001).

No que se refere à configuração de um processo cooperativo, o enfoque adotado pauta-se nos referenciais construídos a partir do cooperativismo popular, que surgiu do movimento operário. Entende-se o 
cooperativismo e as formas de associativismo popular não como espaços meramente institucionais, mas como espaços cotidianos de construção de práticas democráticas baseadas na ética, na solidariedade e na emancipação humana. Transcende a institucionalização e as estruturas formais, sendo respaldado na cotidianidade e na superação do individualismo, do particularismo e do autoritarismo que permeiam as relações cotidianas (Barboza, 2001). Nesse sentido, ao se falar em organizações cooperativas e associativistas, adotam-se as relações cotidianas como foco da análise para a compreensão da cidadania e da democracia. Portanto, a cooperação, a ética, a cidadania e a solidariedade não são concebidas aqui como formas de institucionalizar perspectivas de inclusão, mas consistem em um projeto político social voltado para a transformação das relações cotidianas e para a construção de uma sociedade plural, democrática e cidadã.

Sobre as relações dos catadores com os processos cooperativos, cabe lembrar que os catadores de M.R. em Criciúma viveram uma experiência de "cooperação" anteriormente, que colaborou significativamente para a elaboração de referenciais negativos sobre o cooperativismo. A excooperativa, fundada em 1994, possuiu sede desde 1998, mas devido a sérias irregularidades foi destituída de qualquer possibilidade de funcionamento em 2001, sendo que o local veio a ser administrado pela Prefeitura Municipal de Criciúma, passando a funcionar como Centro de Triagem de Resíduos Sólidos. O processo histórico da referida cooperativa foi marcado pelo clientelismo, pela centralização de poder por parte da diretoria, pela falta de clareza no que dizia respeito às questões contábeis e administrativas, assim como pela ausência de significações por parte dos associados sobre a cultura cooperativista. Para a maioria dos associados, ser sócio consistiu em ter possuído um crachá e ter vendido seu material para a cooperativa. A gestão aconteceu sem a participação dos associados no processo de decisões, o que gerou significações acerca do processo cooperativo por parte dos catadores como um processo pautado no autoritarismo, na centralização de poder, no continuísmo das incertezas quanto à busca dos materiais coletados por eles sem dias preestabelecidos, na manutenção de valores baixos pelo seu material coletado, assim como no desrespeito e na desqualificação social. Tal vivência contribuiu para a desesperança no que se refere a melhorias em suas condições de vida e para a fomentação de um sentimento e de um movimento de impotência na construção da sua cidadania. Pôde-se constatar nas reuniões, visitas domiciliares e nas conversas informais com os catadores que o descrédito que emerge de seu contexto relacional em torno das possibilidades de sua organização cooperativa apresenta-se vinculado à experiência anterior.

Para poder compreender o cenário no qual se constituem os catadores enquanto atores sociais, é preciso considerar o contexto em que estão imbricados em seus aspectos macro e microssociais. Ser catador para eles não implicou uma escolha entre muitas possibilidades, mas uma alternativa diante das necessidades de sobrevivência, da situação de desemprego e muitas vezes de miserabilidade. Eles são vítimas dos efeitos excludentes da globalização neoliberal. Evidencia-se na realidade social brasileira a diminuição paulatina do papel do Estado na área social, o que vem elevando os índices de desemprego e subemprego, com o consequente agravamento da exclusão social (Barboza, 2000). Intensifica-se cada vez mais o número de pessoas que se encontram excluídas do processo formal de produção, buscando envolver-se com atividades informais como forma de garantir a sua sobrevivência. Conforme Paugam (1999) toda essa situação de degradação do mercado de trabalho, de estigmatização em torno da pobreza, isolamento, fragilização dos vínculos, ruptura e dependência via assistência social é constituidora de um processo de desqualificação social, que é humilhante e desestabiliza o ser humano em suas relações com os outros e consigo mesmo. Entende-se que estes são aspectos constitutivos do movimento de impotência de ação dos catadores na construção da sua cidadania.

O contexto em que vivemos, sob a égide do capitalismo e imersos nesta "aldeia global", permeia a história e as relações cotidianas. Os sujeitos, excluídos ou incluídos na lógica da globalização da economia, encontram-se submersos nas problemáticas e questões impostas por ela. Heller (1970/2000) aponta que as circunstâncias e o contexto social são determinantes que interferem na constituição do sujeito: "Essas 'circunstâncias' determinadas, nas quais os homens formulam finalidades, são as relações e situação sócio-humanas, as próprias relações e situações humanas mediatizadas pelas coisas" (p.1). A seu ver, a história é a substância da sociedade, portanto este processo é constituído e constituinte do homem, que é produto e produtor da sua história.

O cotidiano e a história são espaços onde se dá a construção da subjetividade dialeticamente. $\mathrm{O}$ sujeito e a subjetividade se constituem na relação com o outro, consigo mesmo, com o mundo, enfim constitui-se no 
campo da intersubjetividade. O intrapsicológico se dá na fronteira com o interpsicológico, ou seja, nada é intrapsicológico sem ter sido construído antes no campo da intersubjetividade. Assim, na perspectiva de Vygotsky trabalha-se com a concepção de condição humana ao invés de natureza humana, pois o sujeito não é a priori, ele se constitui nas relações sociais.

Destaca-se assim a dimensão inextricavelmente social do que se caracteriza como singular. Ou seja: não há um eu enquanto entidade metafísica, pois este só é a partir do outro, do que o constitui e que é por ele constituído. Mais ainda: só me reconheço enquanto eu a partir de outros eus, embate que é constante, posto que a diferença e a diversidade pautam o humano. Porém, o embate se configura na medida em que reconheço esse não-eu e o significo de algum modo, seja rechaçando, ignorando, aproximando ou identificando-me com ele, em um movimento que vincula o não-eu ao eu e o eu ao não-eu (Zanella, Balbinot \& Pereira, 2000, p.244).

Assim sendo, não podemos dicotomizar a objetividade da subjetividade, pois dessa forma estaríamos fadando o objetivo e o subjetivo a entidades abstratas, distantes, desconsiderando a ,historicidade das relações sociais, da constituição do sujeito e da sociedade. E nessa contínua interação, mediada pelos significados construídos, veiculados e apropriados no cotidiano e na história a partir de determinadas condições objetivas, que os atores sociais se constituem. De acordo com Molon (1999),

a subjetividade manifesta-se, revela-se, converte-se, materializa-se e objetiva-se no sujeito. Ela é processo que não se cristaliza, não se torna condição nem estado estático e nem existe como algo em si, abstrato e imutável. E permanentemente constituinte e constituída. Está na interface do psicológico e das relações sociais (p.143-144).

Na perspectiva de Vygotsky, conforme Molon (1999), as relações sociais se convertem em fenômenos psicológicos através da mediação semiótica, ou seja, através dos signos, que são construídos socialmente via atividade humana. $\mathrm{O}$ intrapsicológico se constitui na interface com o interpsicológico, portanto mediado semioticamente, não como algo que se sobreponha, mas como resultado da apropriação, pelos sujeitos, dos significados construídos e veiculados no campo da intersubjetividade, ou seja, na relação consigo mesmo, com o outro, com a realidade. Os signos são apropriados pelos sujeitos, singularizando-se e sendo constituintes do intrapsicológico, que por sua vez não é mero resultante da introjeção do social, mas sim um significado que é apropriado e constituído mediado pelo social e que portanto, segundo Vygotsky, implica um "quase-social". Nesse sentido manifesta-se Zanella (2000):

Solo hay cultura como resultado de la acción de hombres concretos que organizan de forma singular su vivir y lo representan simbólicamente, así como ayos otros y a sí mismos. Esa misma acción humana productora de cultura es productora de los propios hombres, de su psiquismo, humanidad y singularidad, puesto que lo que la caracteriza es el hecho de ser mediada por herramientas técnicas y representacionales-los signos. Estos a su vez son socialmente producidos y transformados y, en el movimiento de la acción emprendida su significación es particularmente apropiada, en contextos históricos específicos. Siendo el signo una producción social, una vez tornado propio, sigue marcado por la dimensión pública, lo que torna al mismo tiempo singular y colectivo (p.77-78).

A constituição do sujeito catador de material reciclável se dá dialeticamente, a partir de um processo que é histórico, simbólico, político, econômico e cultural. Seu movimento, seja de potência ou impotência de ação na construção da sua cidadania, pauta-se numa processualidade e numa historicidade, não podendo ser concebido como decorrente da sua natureza humana e sim, de sua condição humana.

O movimento de potência e/ou impotência de ação dos catadores na construção da sua cidadania é permeado tanto por suas condições objetivas quanto subjetivas. O sentir-se potente ou impotente para lutar, para produzir transformações em suas relações cotidianas é aspecto constitutivo deste movimento, tanto quanto as carências materiais resultantes da desigualdade social e da exploração econômica. Afirma Sawaia (1997):

Morre-se de fome, como, também, morre-se de tristeza pela carência de dignidade. A carência material e a espiritual/afetiva são igualmente criminosas. A exploração e a desigualdade social têm múltiplas facetas. Necessidades emocionais, biológicas e sociais se entrelaçam, negando a cisão entre fenômenos objetivos e subjetivos (p.84).

Potencializar a construção da cidadania destes atores sociais, por conseguinte, deve transcender a busca de melhorias em suas condições de vida através de formas de organizações que aumentem sua renda, devendo estar intimamente atrelado à construção e ao fortalecimento de vínculos 
afetivos e sociais, ao desenvolvimento da sua capacidade argumentativa, autonomia e auto-estima, entre outros aspectos. É preciso considerar a dimensão da afetividade e das emoções ao se pensar no processo de construção da cidadania, pois não se pode dicotomizá-la do processo de consciência. Potencializar implica que dialeticamente estes atores sociais sintam-se capazes de ir cada vez mais fazendo escolhas pautadas em reflexões críticas acerca de seu cotidiano, ressignificando dialeticamente suas relações com o "lixo", com o poder local, com a sociedade civil e acerca das possibilidades concretas de sua organização social e política. Que se sintam fortalecidos para que cotidianamente possam buscar formas de superação para os diversos modos de exclusão, determinismos, estigmatização, massificação, autoritarismos presentes em suas histórias de vida.

O conceito de potência de ação apresentado neste trabalho foi desenvolvido por Sawaia (1999) a partir de sua leitura espinosiana. A seu ver, "potencializar pressupõe o desenvolvimento de valores éticos na forma de sentimentos, desejo e necessidades, para superar o sofrimento éticopolítico" (p.114). Assim, potencializar significa atuar na configuração de formas de ação, pensamento, sentimentos que contribuam na superação do sofrimento ético-político. Potencializar a cidadania destes atores sociais implica atuar na superação de todas as formas e situações que mutilam sua cidadania, sua auto-estima, sua capacidade argumentativa, enfim que inviabilizam sua potência de ação.

A concepção de cidadania adotada neste trabalho parte da perspectiva de Sawaia (1994), que extrapola as condições materiais e precisa ser concebida, incorporada ao sentido de alteridade. Portanto, autonomia e responsabilidade são aspectos constitutivos dela. Cidadania precisa ser constituída considerando-se a heterogeneidade dos atores sociais, das diferentes culturas, modos de ser e de se expressar, pautando-se no respeito às diferenças e à diversidade, seja de ordem étnica, social, cultural, religiosa, etc. Cidadania nesta concepção deve possibilitar aos sujeitos sentirem-se iguais, com os mesmos direitos, sem que por isso precisem homogeneizarem-se nas relações sociais. Segundo Sawaia (1994) muito além do conhecimento da legislação e dos direitos, cidadania está intimamente vinculada às questões de subjetividade que potencializam o movimento do sujeito em busca das transformações socioculturais, da justiça e dos direitos humanos.
Cidadania se expressa na ação política, mas também no desejo, na paixão e nas necessidades, sendo, cada uma delas, passagem de uma instância a outra. (...) Cidadania é consciência dos direitos iguais, mas esta consciência não se compõe apenas do conhecimento da legislação e do acesso à justiça. Ela exige o sentir-se igual aos outros, com os mesmos direitos iguais. Há uma necessidade subjetiva para suscitar a adesão, a mobilização, tanto quanto condições para agir em defesa destes direitos (Sawaia, 1994, p.152).

Vítimas de um processo de desqualificação social, os catadores de material reciclável de Criciúma encontram-se à margem do processo formal de produção, vivendo em condições precárias nas periferias da cidade, sobrevivendo das sobras da sociedade de consumo, sendo constantemente explorados pelos atravessadores e sujeitos a diversas formas de opressão e exclusão. Trabalham expostos a situações de risco, sem a utilização de luvas, de "sol a sol"; têm de suportar o peso das cargas (há os que nem possuem carrinho, carroça e cavalo para fazer a coleta do material reciclável). Neste processo de trabalhar catando lixo, sentem-se humilhados e discriminados pela sociedade, por serem associados ao seu próprio material de trabalho, que é visto como o que pode ser jogado fora, ficar à margem, ser afastado do olhar, das narinas, distanciado do contexto das relações sociais. O trabalho é realizado sob constante exposição ao sol; há precariedade nas suas condições de trabalho, sendo que o peso das cargas, a falta de cuidados com a higiene, com a alimentação, o desgaste físico, as preocupações com as vendas (queixam-se que os atravessadores demoram para buscar o material coletado por eles), com a renda familiar e com as contas para pagar são fatores que contribuem para o aparecimento de doenças, assim como para a constituição de seu movimento de impotência na construção da sua cidadania. Observa-se que quando os catadores adoecem em decorrência de sua necessidade de sobrevivência, de sua situação de subempregado, marcada fortemente pela degradação do mercado de trabalho, não podem parar de trabalhar para cuidarem de si mesmos, pois o sustento familiar e a sobrevivência dependem deste trabalho. Isso gera, muitas vezes, o agravamento do quadro, assim como gera uma impotência de ação no que diz respeito à busca de transformações em suas relações cotidianas e na melhoria de suas condições de vida. Tais fatores vêm demonstrando que esta atividade, da maneira como ocorre, não tem propiciado uma vida saudável a estes trabalhadores. Por isso é 
importante analisar a constituição do sujeito catador focalizando-se a necessidade de superação de seu sofrimento ético-político por meio da potencialização da sua cidadania. Cabe ressaltar que saúde é enfocada sob a ótica de Sawaia (1994/1995), compreendida portanto como um fenômeno complexo, que muito além do biológico abrange o psicológico e o social. "Saúde é uma questão eminentemente sócio-histórica e, portanto, ética, pois é um processo da ordem da convivência social e da vivência pessoal" (p.157). Por isso, "promover a saúde equivale a condenar todas as formas de conduta que violentam o corpo, o sentimento e a razão humana gerando, consequentemente, a servidão e a heteronomia" (p.157). Para a autora, saúde é "a possibilidade de ter esperança e potencializar esta esperança em ação" (p.162). Dessa forma, entende-se que a saúde não está atrelada meramente ao biológico: é processo simbólico, ético, afetivo, político, social e relacional. Encontra-se, portanto, intimamente atrelada à cidadania, aos direitos humanos e à justiça social.

São várias as famílias que sobrevivem da catação de material reciclável em Criciúma e que cooperam no âmbito familiar entre si na catação, coleta, seleção e venda desses materiais. Revelam-se criativos até mesmo na construção dos carrinhos e carroças que constroem das mais diversas formas com os recursos de que dispõem. Circulando pelas ruas das cidades, eles lidam diariamente com os restos da sociedade de consumo e se apresentam como o lado avesso da cultura de consumo e do processo crescente de degradação ambiental que vem ocorrendo em todo o planeta. Conforme Kuhnen (1995) a complexidade sociocultural e ambiental do meio urbano decorre de um longo crescimento predatório, tanto no que diz respeito ao meio ambiente quanto às condições de vida da população, havendo uma necessidade emergente de uma postura de enfrentamento destes problemas. O modelo de desenvolvimento e de sociedade industrial presente na contemporaneidade suscita cada vez mais novas necessidades de consumo, o que traz sérias consequências para o meio ambiente.

Exploram-se cada vez mais recursos naturais, em um ritmo mais rápido do que a terra produz, gerando dejetos a uma velocidade que não lhes permite serem absorvidos. Há, portanto, um confronto entre um consumo de bens cada vez maior e o imperativo de uma eliminação de dejetos compatível com o meio ambiente (Kuhnen, 1995, p.18).
A defesa de interesses dominantes de cunho mercadológico em escala global e também no âmbito local tem sido colocada acima de ações comprometidas com a construção de uma cultura não-poluente, havendo a necessidade da construção de uma consciência em torno do desperdício e da possibilidade de reutilização de matérias-primas, assim como da implementação de políticas públicas que viabilizem a minimização das agressões sofridas pelo meio ambiente (Kunhen, 1995). Vale ressaltar que em todo o país os catadores atuam ao lado das municipalidades e têm um importante papel social, pois contribuem para amenizar os efeitos negativos do desperdício de matéria-prima, reduzindo a poluição ambiental gerada pelo lixo. Segundo Abreu (2001),

esses trabalhadores informais dos lixões e das ruas das cidades são hoje os responsáveis por $90 \%$ do material que alimenta as indústrias de reciclagem no Brasil, fazendo do País um dos maiores recicladores de alumínio do mundo. Além de terem um importante papel na economia, os catadores diminuem a quantidade de lixo a ser tratado pelas municipalidades. (...) Garimpam no lixo o nosso desperdício de recursos naturais que retomam ao processo produtivo como matérias-primas secundárias (p.34).

Estes agentes econômicos e ambientais enfrentam uma situação de sofrimento ético-político, intitulado dessa forma por Sawaia (1999) por estar intimamente relacionado à desigualdade social e aos processos de massificação, exploração, espoliação, discriminação, estigmatização e massificação presentes em seu cotidiano, que mutila a construção da sua cidadania, contribuindo para uma condição de impotência diante da necessidade da luta por transformações em seu cotidiano, em prol de melhorias em sua qualidade de vida. Afinal,

não lhes interessa qualquer sobrevivência, mas uma específica, com reconhecimento e dignidade. Mesmo na miséria, eles não estão reduzidos às necessidades biológicas, indicando que não há um patamar em que o homem é animal. O sofrimento deles revela o processo de exclusão afetando o corpo e a alma, com muito sofrimento, sendo o maior deles o descrédito social, que os atormenta mais que a fome. O brado angustiante do "eu quero ser gente" perpassa o subtexto de todos os discursos. E ele não é apenas o desejo de igualar-se, mas distinguir-se e ser reconhecido (Sawaia, 1999, p.115). 
Não se pode conceber a constituição do sujeito excluído sob rótulo de uma categoria uniforme, homogênea, incapaz de reivindicar seus direitos, ou ainda sob o rótulo de imediatistas, acomodados, vistos como aqueles que simplesmente não querem mudar. É preciso, sim, trabalhar na perspectiva da potencialização da cidadania desses atores sociais, com a possibilidade da sua organização popular em processos cooperativos (cooperativismo popular e associativismo), com a possibilidade do desenvolvimento da sua autonomia, da democracia e da constituição de sujeitos abertos à alteridade.

Contando com a assessoria de uma equipe interdisciplinar do referido projeto de extensão, no dia 14 de dezembro de 2001 os catadores fundaram a Associação dos Trabalhadores Catadores de Material Reciclável do Extremo Sul Catarinense - RECESC. Considera-se que a vinda deles às reuniões para a articulação dessa associação onde se discutem suas condições de trabalho e a possibilidade de se organizarem social e politicamente - denota a esperança em construir um processo cooperativo diferenciado do anterior e marca seu movimento de potência de ação na construção da sua cidadania. Porém, este movimento não é ascendente, nem linear, nem homogêneo — nas falas, nos diálogos com e entre eles, revelam-se as diferentes formas como eles o significam. Suas relações com este movimento são marcadas por avanços e recuos, ora de potência de ação, ora de impotência. Pautam-se na heterogeneidade e na dialética que permeiam a história e a constituição dos sujeitos. Para alguns, a crença e a esperança estão bastante presentes, enquanto para outros é um "sonho" mais distante ou uma utopia. A busca de novos associados ou não, a frequência às reuniões, a forma como se dá o seu envolvimento no processo são aspectos que nos permitem analisar como eles significam e ressignificam suas relações com a associação, como lidam com a configuração deste outro processo cooperativo. O movimento de impotência e/ou potência de ação dos catadores na construção da sua cidadania é dialético, relacional, simbólico e sociocultural.

Tais reflexões, que foram apresentadas sucintamente, serão aprofundadas durante a pesquisa que estou desenvolvendo junto ao Mestrado em Psicologia da Universidade Federal de Santa Catarina UFSC.

Considerar a heterogeneidade presente na constituição destes sujeitos (excluídos) é respeitar as singularidades dos contextos, dos sujeitos e dos processos históricos. É romper com os determinismos, com as diversas formas de exclusão, com a massificação e buscar conhecer cada processo, cada sujeito a partir de sua própria história, considerando suas condições de vida, seus sonhos, sua afetividade, desejos e possibilidades de mudanças. De acordo com Sawaia (1999),

o menosprezo pelo presente fez as ciências humanas esquecerem-se de que a arte, a religião e a política são exercidas no presente, e que este tem que ser olhado de forma capacitadora, cabendo ao psicólogo social evitar atividades que mutilam a sensibilidade, alimentam a passividade, limitam o conhecimento e a reflexão crítica no presente imediato (p.115).

A Psicologia que queremos é esta que se compromete com a construção de uma práxis emancipatória, pautada na ética, na solidariedade, na democracia, na cidadania, na justiça social, nos direitos humanos e comprometida com a construção de sujeitos abertos à alteridade.

\section{Referências}

Abreu, F. (2001). Do lixo à cidadania: estratégias para a ação. Brasília: Caixa.

Barboza, D. (2000). Cooperativismo, cidadania e a dialética da exclusão/inclusão. Psicologia \& Sociedade. 12 (1/2): 54-64.

Barboza, D. (2001). Psicologia Social Comunitária: práxis, estratégias e intervenção junto aos catadores de material reciclável no sul de Santa Catarina. Jornal do CRP-12, 12: 09.

Heller, A. (2000). O cotidiano e a história. São Paulo: Paz e Terra. (Original publicado em 1970)

Kuhnen, A. (1995). Reciclando o cotidiano: representações sociais do lixo. Ilha de Santa Catarina: Letras Contemporâneas.

Molon, S. (1999). Subjetividade e constituição do sujeito em Vygotsky. São Paulo: EDUC.

Paugam, S. (1999). O enfraquecimento e a ruptura dos vínculos sociais: uma dimensão essencial do processo de desqualificação social. Em B. B. Sawaia (Org.) As artimanhas da exclusão: análise psicossocial e ética da desigualdade social. (p.67-86). Petrópolis: Vozes. 
Sawaia, B. B. (1994). Cidadania, diversidade e comunidade: uma reflexão psicossocial. In: M. J. P. Spink (Org.) A cidadania em construção: uma reflexão transdisciplinar. (pp.147-155). São Paulo: Cortez.

Sawaia, B. B. (1995). Dimensão ético-afetiva do adoecer da classe trabalhadora. In: S. T. M. Lane, B. B. Sawaia (Orgs.) Novas veredas da psicologia social. (p.157-168) São Paulo: Brasiliense/EDUC. (Original publicado em 1994)

Sawaia, B. B. (1997). O ofício da psicologia social à luz da ideia reguladora de sujeito: da eficácia da ação à estética da existência. In: A. V. Zanella, M. J. T. Siqueira, L. A. Lullier \& S. I. Molon (Orgs.) Psicologia e práticas sociais. (p.7891) Porto Alegre: ABRAPSOSUL.

Sawaia, B. B. (1999). O sofrimento ético-político como categoria de análise da dialética exclusão/inclusão. In: B. B. Sawaia (Org.) As artimanhas da exclusão: análise psicossocial e ética da desigualdade social. (p.97-118) Petrópolis: Vozes.

Santos, B. S. (2000). Introdução a uma ciência pós-moderna. Rio de Janeiro: Graal. (Original publicado em 1989)

Zanella, A. V., Balbinot, G. \& Pereira, R. S. (2000). A renda que enreda: Analisando o processo de constituir-se rendeira. Educação \& Sociedade, 71(2), 235-252.

Zanella, A. V. (2000). Aproximaciones a la temática de la constitución del sujeto en Vygotsky y E. Morin. Psykhe, 9(2), 75-81.
Constituição do sujeito e relações de gênero em um contexto de ensinar e aprender

Silvia Zanatta Da Ros ${ }^{1}$ Sandra Iris Sobrera Abella

\section{Introdução}

O presente trabalho traz reflexões sobre dois sujeitos em contexto grupal, considerando os movimentos realizados pelos mesmos a partir do pressuposto de que se constituem socialmente. Enfoca, também, a complexidade da mútua constituição entre sujeito e grupo, sendo que essas duas instâncias não devem ser compreendidas como opostas, mas entrelaçadas por uma relação dialética, pois

o grupo social é na verdade um espaço de encontro/confronto de singularidades que ali se expressam/ constituem/transformam, configurando-se ao mesmo tempo como um coletivo e locus diferenças (Zanella, Lessa, \& Da Ros, 2002, p.17).

Assim, pode-se afirmar que o sujeito, em contexto de grupo, constitui-se como singular e ao mesmo tempo como possuidor de características comuns aos demais membros do grupo. Sendo assim, constitui e é constituído pelas relações ali originadas.

Os estereótipos e as relações de gênero permeiam toda a análise realizada. O enfoque, neste trabalho, deve-se ao fato de dois sujeitos do grupo, um homem e uma mulher, terem assumido lugares sociais de destaque no desenvolvimento do grupo e realizaram movimentos de inserção semelhantes, durante sua participação em um curso de formação de gerentes em serviço.

${ }^{1}$ Doutora em Psicologia da Educação pela Pontifícia Universidade Católica de São Paulo (PUCSP). Professora do Departamento de Estudos Especializados em Educação, da Universidade Federal de Santa Catarina (UFSC).

${ }_{2}^{2}$ Mestranda do Programa de Pós-Graduação em Psicologia, da Universidade Federal de Santa Catarina (UFSC) 


\section{Fundamentação teórica}

Conforme a abordagem histórico-cultural, o sujeito é compreendido predominantemente como ser social,

indivíduo concreto, mediado pelo social, indivíduo determinado histórica e socialmente, jamais podendo ser compreendido independentemente de suas relações e vínculos (Neves, 1997, p.9).

As relações sociais e vínculos estabelecidos são fundamentais, tendo em vista que é nesse contexto relacional que o sujeito se constitui como tal, na sua singularidade. Sendo assim, pode-se afirmar que é no espaço da relação com o outro, ou seja, no espaço da intersubjetividade, que a singularização torna-se possível através do movimento do sujeito em meio às relações sociais, numa relação dialética sujeito - grupo - sujeito. Ou seja,

a partir do funcionamento intersubjetivo, a constituição do sujeito na sua singularidade, (...) envolve diferenças e semelhanças frente ao outro, movimentos de aproximação e afastamento do outro, posturas de convergência e divergência em relação ao outro. O sujeito é uma composição, nada uniforme e regular, dessas tensões e sínteses (Góes, 1993, p.5).

Assim, conforme a concepção aqui esboçada, o espaço de intersubjetividade vem a ser o "lugar do encontro, do confronto e da negociação dos mundos privados, ou seja, de cada interlocutor à procura de um espaço comum de entendimento e produção de sentido, mundo público de significação" (Pino apud Neves, 1999, p.4).

Nesse contexto, o sujeito apropria-se de modo singular dos significados socialmente compartilhados atribuindo-lhes sentidos particulares, o que o constitui como parte desse todo, porém não como um reflexo especular da realidade na qual está inserido (Pino, 1992). Segundo Friedman,

os sentidos pessoais referem-se a enlaces ou relações atribuídas às palavras no confronto entre as significações sociais vigentes e a vivência pessoal. Estão dessa forma ligados a momentos e situações dadas, a motivos e afetos, às atividades e experiências particulares vividas pelos sujeitos, que processam e transformam os significados e são capazes de articular uma consciência e um comportamento com maior ou menor grau de crítica em relação à interpretação ideológica da realidade (Friedman, 1995, p.137).
Os lugares ocupados pelos sujeitos através de suas ações nas relações sociais são fundamentais na sua constituição como ser singular e na configuração dessas relações. Com relação à noção de lugar social, esta, segundo Nuernberg (1999) consiste na posição simbólica que o sujeito ocupa no grupo, sendo que essa posição assumida nesse contexto marca os discursos dos sujeitos e, consequentemente, o modo como os mesmos são significados pelos demais, ou seja:

sempre falamos a partir de uma posição enunciativa determinada: de aluno, de professor, de homem, de mulher, de quem ocupa um cargo seja este importante ou não, ou tem formação acadêmica em alguma área do conhecimento e é reconhecido como tal. Com relação a isso, fica claro que tais lugares sociais são constitutivos das significações em curso nas relações sociais (Nuernberg, 1999, p.22).

Além disso, no contexto grupal os indivíduos que nele se inserem pautam sua conduta nas pautas interativas estabelecidas pela coletividade, fator importante na constituição do sujeito, tendo em vista que é a partir dessas pautas que o indivíduo vai regular sua conduta. Quiroga (apud Tschiedel, 1998) afirma que nas interações, as novas elaborações construídas no espaço intersubjetivo possibilitam transformações nos sujeitos e nos grupos aos quais pertencem.

Portanto, nesta concepção ressalta-se a intersubjetividade constitutiva sem, por isso, perder de vista a singularidade do sujeito, pelo fato de que, para Góes, a

tendência crescente para examinar o indivíduo concretamente constituído nos leva a conceber a individualidade como processo, construída socialmente e a singularidade como conjugação de elementos nem sempre convergentes ou harmoniosos (Góes, 1993, p.5).

Um elemento que se constitui na intersubjetividade e torna-se fundamental nas relações são os estereótipos. Essa importância se justifica pelo fato de que, nas relações entre si, as pessoas tendem a se atribuir características estereotipadas as quais acabam atuando como mediadoras nessas relações, simplificando as percepções. Nesse sentido, pode-se afirmar que as relações ocorrem tendo como base as características prévias que os indivíduos se atribuem entre si, o que vem a consistir em um processo de categorização que subjaz às relações sociais (Alonso \& Berbel, 1997). 
Um estereótipo é a ideia e/ou imagem que surge espontaneamente, logo que se trate de (...) É a representação de um objeto (coisas, pessoas, ideias) mais ou menos desligada de sua realidade objetiva, compartilhada pelos membros de um grupo social com uma certa estabilidade. Corresponde a uma medida de economia na percepção da realidade, visto que uma composição semântica, pré-existente, geralmente muito concreta e imagética, organizada ao redor de alguns elementos simbólicos simples, substitui ou orienta imediatamente a informação objetiva ou a percepção real. Estrutura cognitiva e não inata (submetida à influência do meio cultural, da experiência pessoal de instâncias e de influências privilegiadas como as comunicações de massa), o estereótipo, no entanto, aprofunda suas raízes no afetivo e no emocional, porque está ligado ao preconceito por ele racionalizado, justificado ou engendrado (Bardin, 1977, p.52).

Entre os diversos estereótipos que podem surgir em contexto grupal, o estereótipo de gênero consiste no "conjunto de crenças acerca dos atributos pessoais adequados a homens e mulheres, sejam estas crenças individuais ou partilhadas" (D'Amorim, 1997, p.122). O constructo de gênero foi criado para enfatizar uma diferença entre homens e mulheres, não em termos biológicos, definidos pelo sexo, mas que dizem respeito a fatores culturais, sendo uma construção histórica, social e cultural, englobando aspectos como: comportamentos, interesses, estilos de vida, tendências, responsabilidades, papéis, sentimentos/consciência de si, personalidade, afetos, intelecto e emoções (Strey, 1998). "O gênero depende de como a sociedade vê a relação que transforma um macho em um homem e uma fêmea em uma mulher" (Strey, 1998, p.183), ou seja, as imagens que uma determinada cultura veicula a respeito do que significa ser homem e mulher, levam a um determinado desempenho e a uma determinada forma de relacionar-se entre si.

Os estereótipos de gênero conferem atributos que valorizam as atividades desenvolvidas pelos homens, quer em seus desempenhos profissionais, esportivos, bem como no que se refere à liderança, tomadas de decisão, etc. Assim, pode-se afirmar que os estereótipos de gênero conferem atributos que valorizam as atividades desenvolvidas pelos homens, não somente em seus desempenhos profissionais, senão também no que se refere à liderança, tomadas de decisão, etc.
Apesar de ter ocorrido mudança em relação às mulheres em nível de atitude, sendo inclusive aceita uma maior independência no modo de agir, modos de falar e escolhas profissionais, antes não considerados, persiste o estereótipo da mulher como alguém fraco que precisa de proteção. Esse fato se deve, em parte, à mídia,

que valoriza a juventude e a beleza como características desejáveis nos homens, porém essenciais nas mulheres. Do mesmo modo, a inteligência, a persistência e a capacidade são indispensáveis ao homem e desejáveis na mulher que deve, de preferência, ser educada, culta e possuir aptidões artísticas (D’Amorim \& Gomide apud D’Amorim, 1997, p.131-132).

De modo geral, com base no anteriormente exposto, pode-se dizer que o contexto grupal é complexo, onde parte e todo não podem ser separados de modo dicotômico tendo em vista que ambas as instâncias se constituem concomitantemente, estando imbricados aspectos como as características demonstradas pelos sujeitos e os estereótipos que lhe são atribuídos pelos demais e que, ao mesmo tempo, também atribui aos demais. Esse fato acaba formando um espaço de relação onde diversos aspectos como gênero, cultura e sociedade estão sempre presentes e influenciando as relações de modo complexo.

\section{Sobre a pesquisa realizada}

Foram analisados dois sujeitos, funcionários públicos em um órgão da administração direta, participantes do Programa de Formação de Gerentes em Serviço (PFGS). O curso, desenvolvido no decorrer de duas semanas, promovido pela instituição em que trabalham, foi programado tendo em vista estimular uma visão crítica e o vir a ser em termos de mudança na mesma.

Houve participação de dois consultores: um da área psicossocial e outro da área organizacional, que desenvolveram os temas acima mencionados. O primeiro acompanhou todo o desenrolar do trabalho, mesmo nos momentos nos quais a coordenação esteve a cargo do consultor da área organizacional. $\mathrm{O}$ fechamento dos trabalhos foi realizado por esta consultora no último dia do programa. Cabe ainda mencionar que na segunda semana de atividades, a turma teve que se juntar a uma outra pelo fato de um dos consultores organizacionais ter faltado. 
A abordagem histórico-cultural fundamentou todo o desenvolvimento do processo, na qual o ser humano é compreendido como síntese das relações sociais, pressuposto e resultado destas relações (Marx \& Engels, 1980). A visão crítica da realidade foi, portanto, um ponto fundamental que permeou todas as atividades desenvolvidas e encaminhadas no sentido de que cada servidor, em particular, pudesse compreender seu lugar como ator social, sujeito ativo constituidor do social, mas também constituído pelo mesmo.

Os dados obtidos constam de gravação das falas em fita-cassete; imagens em vídeo; produções escritas decorrentes das atividades propostas; anotações feitas pelo monitor da turma e avaliações escritas realizadas pelos próprios sujeitos. Esses dados foram posteriormente tratados através de análise dos discursos registrados e dos movimentos dos sujeitos que puderam ser observados no decorrer do programa de formação em serviço.

O grupo, composto por 20 pessoas, pode ser descrito por algumas características predominantes, sendo formada, em sua maioria, por homens $(65 \%)$, casados $(75 \%)$, que ingressaram na instituição através de concurso de nível superior $(70 \%)$, ocupantes de cargo de chefia (55\%), com um tempo de serviço acima de 15 anos (50\%), e que vivem e trabalham na região Sudeste $(40 \%){ }^{3}$

No tocante às características acima mencionadas que os sujeitos analisados possuem, Lígia é casada, funcionária de nível técnico, não ocupa cargo de chefia, tem tempo de serviço superior a $\mathbf{1 5}$ anos e também trabalha e vive em uma cidade no interior do estado de São Paulo. Quanto a Álvaro, este é divorciado, funcionário de nível superior, também tem acima de $\mathbf{1 5}$ anos de serviço na instituição, provém da região centro-oeste, e trabalha na capital do país. Através da comparação entre as características dos sujeitos e da maioria dos participantes do grupo, pode-se afirmar que ambos possuem algumas características que os inserem na média do grupo e outras que os diferenciam da maioria.

\footnotetext{
${ }^{3}$ Estes dados foram obtidos em uma atividade de atribuição de adjetivos, realizada no primeiro dia do programa em questão.
}

Os sujeitos e sua relação com os demais participantes

\section{Álvaro}

Com relação às diversas características demonstradas por Álvaro no decorrer do PFGS, inicialmente os estereótipos que recebeu deveram-se às categorias às quais pertence na instituição, tendo sido explicitadas através de uma atividade proposta ao grupo. ${ }^{4} \mathrm{O}$ sentido, com relação a esses estereótipos, foi predominantemente positivo, tendo sido caracterizado como alguém que ocupa um lugar privilegiado na instituição. Os adjetivos que lhe foram atribuídos pelos colegas foram: quanto ao tempo de serviço de 15 a 30 anos - decano; sexo masculino - iludido; estado civil divorciado - soltinho; condição de inserção através de concurso de nível de escolarização superior - marajá; região de lotação Brasília - impessoalidade; órgão onde trabalha 'órgão central' - iluminado. Assim, Álvaro aparece descrito por características que, pelo menos inicialmente, parecem colocá-lo em uma certa posição de destaque, o que se pode afirmar pelo fato de que os estereótipos a ele atribuídos foram predominantemente positivos.

Com relação ao gênero, a adjetivação atribuída aos homens pertencentes à turma (iludido) parece demonstrar que as mulheres consideram que eles se iludem pensando que são os que mandam e lideram quando, na realidade, quem está por trás e realmente faz que tudo aconteça são as mulheres. Assim, essa significação parece demonstrar como as relações de gênero na instituição são percebidas pelas mulheres do grupo. Esse adjetivo pode ter os seguintes significados, conforme aparece no dicionário: "enganado; frustrado; que vive em ilusão ou em erro".

Descrevendo resumidamente o movimento realizado por Álvaro durante as atividades propostas no programa e o modo como foi significado no decorrer do mesmo, foi observado que, a princípio, se mostrou distante, mais um observador, por duas ou três vezes fez intervenções tentando descaracterizar o que o grupo ou algum colega havia concluído. Chegou,

\footnotetext{
${ }^{4}$ A atividade da atribuição dos adjetivos consistiu na organização de subgrupos a partir de algumas temáticas propostas pela coordenadora - tempo de serviço, sexo, estado civil, condição de inserção, região de lotação e órgão onde trabalham — com o objetivo de traçar um panorama do grupo que começava a se formar. Este foi um momento de descontração em que os participantes conversavam entre si nos subgrupos formados. Todos opinaram até chegar a um consenso com relação ao adjetivo a ser atribuído a cada subgrupo formado.
} 
inclusive, a se manifestar com conversa paralela, buscando descaracterizar o que a coordenadora ou algum colega havia dito. Assim, nos primeiros dias parecia ambivalente entre atitudes individualistas e de proximidade com o grupo, no entanto, tornou-se mais integrado e descontraído a partir da atividade de atribuição dos adjetivos. Nas atividades seguintes, foi destacando-se como uma das figuras essenciais no grupo, mostrando atitudes mais firmes que nos primeiros dias, exercendo papel de líder em diversas atividades.

Em uma delas, na preparação para a apresentação de uma pequena esquete que enfocava situações vivenciadas em seu local de trabalho, emergiu como líder, juntamente com Lígia e um outro colega, Mauro, em um momento de aparente confusão e desorganização geral em que o grupo demonstrou possuir necessidade de organização. Nesse momento, os três se adiantaram nas discussões, trazendo sugestões de temas a serem enfocados. Essa atividade integrou os participantes, que começavam a fortalecer um vínculo afetivo. ${ }^{5}$

No final da segunda semana, Álvaro estava integrado, tendo sido percebido como alguém alegre e que mudou o ambiente do grupo, conforme a fala de um de seus colegas no curso. Assim, chegou, juntamente com Lígia, a constituir-se em um laço de união entre as duas turmas que se juntaram para desenvolver as atividades da área organizacional, formando um coletivo de 40 pessoas.

Em suma, Álvaro inicialmente mostrou-se sério e irônico, foi um elemento desorganizador, distante e depois, no decorrer do programa, acabou constituindo-se como elemento organizador no e do grupo, assumindo o lugar social de líder, de ponto de equilíbrio para sua turma de origem e de mediador entre as duas turmas que trabalharam juntas na segunda semana do PFGS.

\section{Lígia}

Os estereótipos atribuídos à Lígia por seus colegas, conforme categorias nas quais se insere foram as seguintes: sexo feminino -

\footnotetext{
${ }^{5}$ No terceiro dia do curso, foi proposta uma atividade que consistiu em uma encenação realizada em conjunto pelo grupo todo para ser apresentada para as demais turmas participantes, tendo como tema algum aspecto da realidade da instituição na qual trabalham.

eminência parda; estado civil casada - Viagra; modo de ingresso na instituição através de exame de nível técnico - emergente; tempo de serviço superior a 15 anos - decano; trabalha no estado de São Paulo apressada; e, quanto ao órgão onde trabalha, qual seja, o setor de atendimento ao consumidor - peão. De modo geral, esses adjetivos parecem caracterizá-la como alguém que luta para assumir uma posição melhor na instituição, contudo, diferentemente de Álvaro, não aparece caracterizada como alguém que ocupa um lugar de destaque na mesma.

A adjetivação atribuída pelos homens da turma às mulheres (eminências pardas), parece demonstrar que eles as percebem como pessoas que se destacam, mas, contraditoriamente, desejam passar despercebidas (ou é o que acaba acontecendo), sem atrair a atenção sobre si. Possivelmente se trate de uma dificuldade da mulher em ocupar posições de liderança na instituição ficando, portanto, atrás dos homens aparentemente, mas na verdade são quem manda e fazem com que tudo realmente aconteça.

A princípio, relacionou-se com o grupo mais timidamente não se expondo muito. Entretanto, na medida em que foi conhecendo mais as pessoas, foi participando e se integrando mais. No decorrer do processo e em meio à interação com os colegas, Lígia foi significada pelo grupo, segundo os dados obtidos, como uma pessoa ativa, forte, responsável, decidida, que congrega as pessoas, líder, mãezona e centralizadora. Chegou a tornar-se liderança e um dos elementos reconhecidos pelos demais colegas como fundamentais como ponto de equilíbrio no grupo. Também chegou a exercer função de mediadora na integração com a outra turma com a qual tiveram que conviver na segunda semana de atividades. Assim, constituiu-se no grupo como uma pessoa que o liderou em momentos fundamentais para o mesmo e um ponto de apoio para seus colegas.

\section{Análise dos movimentos dos sujeitos a partir da revisão teórica}

A partir das características demonstradas pelos sujeitos e, por conseguinte, pelos estereótipos atribuídos pelos demais colegas, pode-se observar o modo como Álvaro e Lígia foram percebidos no grupo. Assim, pode-se afirmar que os estereótipos configuraram uma relação mútua entre o modo como os sujeitos se revelaram no processo de ensinar e aprender promovidas e também como o próprio grupo foi significando os modos como os sujeitos se mostraram, aceitando ou não a sua inserção efetiva no grupo. 
Desse modo, Álvaro aparece significado de modo positivo pelos colegas, presumindo-se, portanto, que foi aceito como parte do grupo. Esse fato possivelmente possibilitou sua inserção no mesmo, tendo em vista que inicialmente não participou muito $\mathrm{e}$, de certo modo, tentou boicotar a participação dos demais colegas. No entanto, também pode-se concluir que Álvaro constituiu-se como possuidor dessas características a partir do significado acolhedor que atribuiu ao grupo, como pode ser observado através de sua fala a seguir: o grupo foi acolhedor, permite abertura e eu me $a b r i$. E, ao mesmo tempo, pode-se tentar afirmar que o grupo tenha agido de modo acolhedor com ele por ter aceitado e valorizado as características por ele demonstradas. Contudo, Álvaro fez parte do grupo e exerceu funções no mesmo que influíram na constituição do grupo como tal.

De modo semelhante a Álvaro, Lígia também foi aceita pelo grupo a partir das características por ela demonstradas no decorrer das atividades. Assim, conforme análise de sua própria fala, inicialmente relacionou-se timidamente e, na medida em que foi conhecendo melhor os seus colegas, foi se mostrando mais descontraída e foi se inserindo progressivamente no grupo, o que lhe possibilitou constituir-se assumindo novas características não observadas no início das atividades. Similarmente a Álvaro, ela significou o grupo como facilitador para todos que desejassem se manifestar e soube respeitar aqueles que em determinados momentos não queriam manifestar-se. Assim, com base na análise do movimento observado e de sua fala, pode-se afirmar que como não foi sentindo-se pressionada pelo grupo a participar mais, foi conseguindo se inserir no mesmo e demonstrar as características de líder e de mediadora enfatizadas por seus colegas.

Ainda com relação às relações de gênero, torna-se importante destacar a fala de um dos colegas a respeito de Lígia: Eu gosto de mulheres fortes, de mulheres ativas, que tomam parte nas decisões, nas coisas que devem ser feitas, eu gosto de andar lado a lado com a mulher e não à frente. Esta fala indica, comparando-se com os resultados de dados de pesquisa (D' Amorim, 1997), que parece ter ocorrido uma mudança nos homens, os quais preferem que as mulheres ocupem uma posição de maior destaque, de decisão e liderança, em vez de uma posição de submissão que há algum tempo atrás era visto como sinal de feminilidade. Nesse sentido, vale destacar que Lígia aparece descrita com as características de líder e ao mesmo tempo com características tidas como femininas: elegante, bonita, vaidosa.

Aqui, é interessante destacar que Lígia, como líder, é vista como alguém forte, decidida, que congrega e catalisa as forças do grupo, sendo, possivelmente por esse motivo, associada à figura materna, assumindo uma função de destaque sem perder, por isso, a feminilidade, do modo como parece ser compreendida pelos colegas homens, que a caracterizaram com atributos caracteristicamente vistos como femininos: elegante, vaidosa. Portanto, através desta associação pode-se perceber uma concordância com a identificação da função da mulher com a de mãe (Broverman, Vogel, Clarkson, \& Broverman apud D’ Amorim, 1997).

Já Álvaro exerceu função semelhante de elo de ligação entre as turmas, porém isso não foi tão enfatizado como no caso de Lígia, o que pode levar a pensar que é mais esperado que esse lugar seja ocupado por homens do que por mulheres. Assim, seria esperado dele que fosse forte, decidido e catalisador das forças do grupo - características que foram ressaltadas no caso de Lígia. O fato de Álvaro ter congregado as duas turmas na segunda semana de atividades pouco foi destacado, tendo sido apenas caracterizado como ponto de equilíbrio do grupo e como alguém que alegrou o mesmo.

Pelo exposto é possível verificar a presença da mutualidade sujeito/grupo como pilar no qual assenta-se a dialética da relação parte/todo, onde o sujeito, enquanto parte e singularidade constitui o todo, que por sua vez também o constitui como sujeito. Essa mutualidade, mediada intensamente pela coordenadora, colaborou para que o coletivo se transformasse em um grupo. Há que se observar, também, a não linearidade que caracterizou as atividades. Idas e vindas marcaram a dinâmica das vivências que foram significadas e ressignificadas no que se refere aos estereótipos e às questões de gênero. Isto conferiu ao grupo uma flexibilidade que suportou o fato de ter que se unir a uma outra turma para trabalhar aspectos organizacionais específicos sem desestruturar o que havia conseguido construir em termos grupais. Para tanto, a participação dos dois sujeitos acima analisados foi de fundamental importância, pois juntamente com os demais componentes do grupo, amparados, incentivados e autorizados pelos mesmos, mediaram relações interpessoais num contexto complexo de ensinar e aprender. 


\section{Referências}

Alonso, R. \& Berbel, S. (1997). Procesos grupales e intergrupales. In: P. Gonzalez (Ed.), Psicología de los grupos: Teoría y aplicación (p.141-166). Madrid: Síntesis.

Bardin, L. (1977). Análise de conteúdo. São Paulo, SP: Martins Fontes.

D’Amorim, M. A. (1997). Estereótipos de gênero e atitudes acerca da sexualidade em estudos sobre jovens brasileiros. Temas em Psicologia, 3, 121134.

Góes, M. C. R. de. (1993). Modos de participação do outro no processo de significação. Temas em Psicologia, 1,23-29.

Marx, K. \& Engels, F. (1980). A ideologia alemã. São Paulo: Martins Fontes.

Neves, W.M.J. (1997). As formas de significação como mediação da consciência: Um estudo sobre o movimento da consciência de um grupo de professores. Tese de Doutorado não-publicada, Pontifícia Universidade Católica de São Paulo, São Paulo, SP.

Nuernberg, A. H. (1999). Investigando a significação de lugares sociais de professora e alunos no contexto de sala de aula. Dissertação de Mestrado não-publicada, Universidade Federal de Santa Catarina, Florianópolis, Se.

Pino, A. (1992). As categorias do público e do privado na análise do processo de internalização. Caderno CEDES: Educação e Sociedade, 42, 315-327.

Strey, M. N. (1998). Gênero. In: M. N. Strey (Ed.) Psicologia social contemporânea: Livro-texto (pp.188-198). Petrópolis, RJ: Vozes.

Tschiedel, R. G. (1998). O grupo como espaço de construção: da heterogeneidade à heterogênese. Dissertação de Mestrado nãopublicada, Pontifícia Universidade Católica do Rio Grande do Sul, Porto Alegre, RS.

Zanella, A. V., Lessa, C. T., \& Da Ros, S. Z. (2002). Contextos grupais e sujeitos em relação: contribuições às reflexões sobre grupos sociais. Psicologia: Reflexão e Crítica. 15 (1), 211-218.

\section{Questões de gênero em grupos de terceira idade}

Katia Simone Ploner Almir Sais

Marlene Neves Strey

Na década de 70, iniciou-se no Brasil, os denominados Grupos para a Terceira Idade com o objetivo de promover a socialização, a atualização ou o desenvolvimento pessoal (Ferrigno, 1998). Os Grupos de Terceira Idade são vistos por alguns gerontólogos como uma alternativa para que as pessoas mais velhas continuem ativas, melhorem sua auto-estima, percepção de si e da vivência do processo de envelhecimento (Veras e Camargo, 1995; Neri e Cachioni, 1999).

Mas, o que é a terceira idade? Para Debert (1999) a invenção da terceira idade remete a padrões da modernidade que representam uma comunidade aposentada com saúde, independência financeira, possibilidade de satisfação e realização pessoal. A expressão terceira idade foi vinculada a um tempo de lazer, liberdade e prazer (Peixoto, 1998), buscando substituir o incômodo provocado pela palavra velhice. Esta última, no atual contexto social, é relacionada a características como pobreza, doença, feiúra, inutilidade (Simões, 1994)

A troca de termos tem tido a função de encobrir uma realidade e é indissociavelmente, um trabalho de eufeminização (Peixoto, 1998). Quando se vê uma empresária, um senador, uma pesquisadora notável, um ator de sucesso com sessenta anos ou mais, suas velhices são dissimuladas, pois estão em posições de prestígio ou cargos de poder. Muitas vezes, os velhos/as comuns, especialmente quando tem algum atributo do estereótipo da velhice como doença ou pobreza, não são mais vistos como pessoas e

\footnotetext{
${ }^{1}$ Este artigo foi produzido a partir de dissertação "Bolinha não entra em clube de Luluzinha: questões de gênero em grupos de terceira idade" apresentada para Mestrado em Psicologia Social e da Personalidade-PUCRS.

${ }_{2}^{2}$ Mestre em Psicologia Social e da Personalidade (PUCRS), Professora no Curso de Psicologia - UNIVALI.

${ }^{3}$ Mestre em Psicologia Clínica (PUCSP), Professor do Curso de Psicologia da UNIVALI

${ }^{4}$ Doutora em Psicologia Social pela Universidad Autônoma de Madrid, professora na PUCRS. 
sim como velhos/as. Iguala-se todas as pessoas acima de sessenta anos sob o signo da velhice, despersonalizando-as (Sais, 1995).

Vivendo sob o estereotipo de pertencer à classe dos velhos/as, na marginalidade da produção de bens e serviços úteis a sociedade regida pelo mercado, é que muitos velhos/as precisam de tutela, de auxílio. Essa, porém, não é uma condição criada pelo envelhecimento. É uma necessidade que se impõe devido ao modo como vivemos, que desmonta as bases de acolhimento da velhice.

É nesse contexto que os grupos de terceira idade são apresentados como possibilidade de interrelações, um espaço específico para a vida de pessoas com mais de sessenta anos de idade acontecer. Porém, nos chamados grupos de terceira idade a velhice não é igual: contradições, tensões, diferentes forças estão borbulhando nas relações entre velhos e velhas, para além de suas singularidades.

As questões que permeiam a construção de gênero são forças que não estão presentes apenas no corpo, mas nas entranhas do pensar, do sentir, do olhar para o outro e para si mesmo/a, arraigados e produzidos a partir de uma ideologia, de relações desiguais de poder. Um traço da cultura dos grupos de terceira idade que pede para ser revelado, pois, caso não seja feito, corremos o risco de perceber estes processos como naturais

Nestes grupos é comum a participação diferenciada no número de homens e mulheres, sendo que a participação masculina é próxima de $20 \%$, quando muito (Sant'Anna, 1997; Peixoto, 1997; Veras e Camargo, 1995). Nos últimos anos este fenômeno tem sido estudado também como uma questão de gênero (Debert, 1994; Sant'Anna, 1997; Mattos, 1999).

Essa análise sobre gênero deve estar presente em estudos de situações geradoras de desigualdades, tendo como objetivo erradicá-las, já que são construídas socialmente e, portanto, modificáveis (Strey, 1998). A forma como se atribui comportamentos, regras, normas diferentes para homens e mulheres institui, sob o engodo da naturalização, relações desiguais e que trazem sofrimento para ambos.

Os grupos de terceira idade constituíram-se como espaços ocupados, em sua maioria, por mulheres. Diante da pouca presença de homens nestes grupos, surgiu o interesse em pesquisar quais processos estavam implicados nesta ausência masculina. A questão era, especificamente, porque poucos homens participam dos Grupos de Terceira Idade?

\section{O caminho percorrido}

A perspectiva qualitativa foi escolhida para nortear este trabalho. Na coleta de dados, optou-se pela entrevista semi-estruturada, conforme conceito de Trivinos (1987). A escolha por esta técnica deu-se pelo interesse em estudar a relação que o entrevistado estabelece com o mundo vivido, atribuindo-lhe sentidos, significados, interligações, sensações que se expressam através do discurso (Gomes, 1997).

A entrevista teve um roteiro com tópicos, buscando levantar dados da história dos entrevistados que estabeleciam interfaces com o tema da pesquisa e a compreensão que tinham sobre os Grupos de Terceira Idade. As perguntas buscavam desvendar como se relacionavam com o trabalho, com a aposentadoria, com o envelhecimento, com a chamada "terceira idade"; a participação ou não de grupo(s) de terceira idade e por quê, a relação estabelecida com esses grupos e sua representação. Além disso, possíveis hipóteses que os entrevistados levantavam para a pouca participação dos homens nos Grupos de Terceira Idade.

Os entrevistados foram oito homens de sessenta anos ou mais Destes, dois participavam ativamente, dois eram ex-participantes e quatro não participavam dos grupos de terceira idade. Quanto ao grau de escolaridade, três tinham primeiro grau incompleto, três tinham segundo grau completo e dois terceiro grau completo. Sete deles estavam casados e apenas um era viúvo. A média de idade ficou em torno de 71 anos. Eram residentes do município de Itajaí ou de Balneário Camboriú. Pertenciam a diferentes faixas econômicas e contextos culturais.

Respeitando os princípios éticos de sigilo e anonimato utilizou-se nomes fictícios neste texto. Para registro dessas entrevistas, utilizou-se um gravador portátil, com a devida autorização dos entrevistados. Todas as entrevistas realizadas foram transcritas, para posteriormente serem sistematizadas e analisadas.

O método designado de "análise de conteúdo" (Bardin, 1991) foi utilizado para organizar esses dados. A teoria histórico-crítica, as teorias de 
gênero e de envelhecimento foram utilizadas para discutir e interpretar os dados coletados.

Vários autores que dissertaram sobre análise de conteúdo (Richardson, 1989; Bardin, 1991; Moraes, 1993; Navarro e Díaz, 1994) descrevem suas fases em três grandes etapas: a pré-análise, a exploração do material e o tratamento dos resultados. Neste caso, construiu-se as categorias a posteriori, com critérios norteadores como: validade, exaustividade, homogeneidade, exclusividade e consistência (Laville e Dionne, 1999; Kude, 1999; Minayo, 1999; Moraes, 1999).

A elaboração das categorias foi um processo dialético, com sucessivas reconstruções, em discussão com o material coletado, autores e pessoas qualificadas na área. Partiu-se do pressuposto de que a ciência não é neutra, não pode conter em si a verdade absoluta e uma única leitura de qualquer fenômeno estudado. Logo, esse conhecimento é social, histórico, construído a partir de várias contribuições e referem-se aos seus participantes, sendo específicos, sem caráter generalista.

\section{Os homens estão com a palavra}

A pesquisa tornou evidente que o Grupo de Terceira Idade não é apenas uma reunião de pessoas com mais de sessenta anos. Uma das contribuições desta pesquisa é a definição das características de um Grupo de Terceira Idade (GTI): é organizado sistematicamente, com regularidade, periodicidade, tarefas e local definidos, vinculado a uma organização governamental ou não governamental e sendo qualificado como grupo de terceira idade pelos seus participantes.

Os grupos formados por alguns homens que se encontram em diferentes lugares como nas praças, nos bares, nas praias, nas canchas de bocha, nas associações dos aposentados, nos clubes ou um grupo de amigos, não são vistos pela maior parte dos entrevistados como GTI, mesmo que sejam formados por pessoas com mais de sessenta anos. $\mathrm{O}$ mesmo é válido para mulheres, seja grupo de professoras ou de amigas, com mais idade que se encontram no restaurante que sempre frequentaram, ou para um chá na casa de uma delas. Debert (1999) aponta esta distinção dos GTI em relação a associações filantrópicas, por exemplo, que congrega pessoas mais velhas, mas que a idade não tem a dimensão central nas atividades desenvolvidas.

Ter uma função terapêutica foi apontado como característica dos Grupos de Terceira Idade. O entrevistado denominado Afonso (75 anos) sugeriu a criação de um grupo específico e exclusivo para os homens, importante para melhorar a saúde e/ou ter um desenvolvimento emocional, psíquico ou mental. Ele elaborou a sua proposta: seria útil para o homem, (...) depois de velho, desenvolver ali ao menos o estilo dele, ou a própria saúde (Afonso, 75 anos). Para ele, o Grupo de Terceira Idade é um apoio para enfrentar as vicissitudes da vida na velhice.

Estevão (75 anos) e de Milton (73 anos) confirmam que estes grupos têm como finalidade instruir para o autocuidado em relação à saúde e fornecer orientações para viver bem a terceira idade e promover convivência social. Milton (73 anos) salienta que as pessoas que precisam destes grupos não tem autodeterminação.

A delimitação da representação do que é o Grupo de Terceira Idade para esses entrevistados trouxe explicações sobre possíveis motivos para poucos homens participarem deles: não precisar de orientações ou cuidados e não desejar estar vinculado a um grupo de velhos parecem ser dois destes motivos.

Os entrevistados, de um modo geral, trouxeram as questões relativas ao gênero, ${ }^{5}$ apresentando o grupo de terceira idade como sendo grupo de e para mulheres. Confirmam o que Debert (1994) aponta ao afirmar que as associações de terceira idade existentes, na maioria quase absoluta, são compostas de mulheres (Estevão, 75 anos). Peixoto (1997), ao levantar o perfil dos estudantes da Universidade Aberta da Terceira Idade, escreveu que apenas 16,4\% dos/as alunos/as inscritos são do sexo masculino. Sant'Anna (1997, p.80) percebendo as diferenças entre homens e mulheres na participação em grupos sociais afirmou que existe "a necessidade de tratar a Terceira Idade, também, como uma questão de gênero". Uma

\footnotetext{
${ }^{5}$ Gênero aqui é entendido enquanto aspectos sociais, culturais e psicológicos que compõe representação do feminino e do masculino e não propriamente o sexo biológico. Por isso, não é possível falar de homens sem falar de mulheres, pois estes são compreendidos em relação.
} 
possibilidade de análise é através das relações de gênero e valores separatistas e excludentes entre os sexos.

A exclusão que os homens sofrem nos grupos de terceira idade é evidenciado pelos entrevistados. Afonso (75 anos) afirma que quando os homens participam dos grupos das mulheres, eles vão lá só para olhar mesmo, mas eles não têm participação em nada, né? Elas dançam lá entre elas.

Estevão (75 anos) contou que foi em um encontro de idosos, em que tinha mais de quatrocentas pessoas, mas a maioria era só de mulher, mulher dança com mulher. Percebe-se por estes relatos que quando os homens estão presentes no grupo, não pertencem a ele.

A ocupação dos cargos de poder e comando nos grupos de terceira idade conhecidos por nossos entrevistados era realizado por mulheres. Estevão (75 anos) comenta que a direção da associação é mulher, o presidente é mulher, o secretário é mulher, o tesoureiro é mulher, é tudo mulher.

Esses relatos nos levam a vislumbrar duas possibilidades para a participação limitada dos homens: a) para manter o poder, as mulheres resistem à participação dos homens e b) para alguns homens pode ser ofensivo e humilhante submeter-se às decisões tomadas por mulheres, devido aos valores sociais discriminatórios.

A utilização de uma linguagem sexista, por parte dos profissionais que coordenam estes grupos, foi ressaltada por Estevão (75 anos): nos cursos de terceira idade, os professores falam para as mulheres e não para os homens, então, eu acho que é um dos pontos que a gente tem que olhar um pouquinho. Esta pode ser uma forma de exclusão e demonstração de indiferença em relação à existência desses homens nestes grupos, promovendo sua invisibilidade.

A discriminação de gênero foi um dos principais motivos apontados (por Alexandre, José, Afonso e Gilnei) para os homens não frequentarem estes grupos. Destaca-se nesta categoria: a) o rechaço em relação às reuniões: é coisa de mulher mesmo fazer reuniões de blá, blá, blá (...) descrito por José (73) ao utilizar-se do discurso de colegas; b) pouca importância dada aos atuais grupos, sem reconhecimento social, conotação pública ou grandes objetivos: nesses Grupos de Terceira Idade não há uma razão objetiva na coisa, é mais uma reunião social, até com um pouco de futilidade (...) aquilo não forma um clube de verdade (Gilnei, 69 anos); c) Ter vergonha ou sentir-se constrangido por serem apenas poucos homens em um grupo de mulheres: os homens, são poucos (...) e um homem no meio das mulheres não. Lá ele é o bendito fruto, né, ele também não se encontra (José, 73 anos); d) Falta de integração entre homens e mulheres: os homens já falaram de tudo que tinham de falar com as mulheres, então eles querem falar coisas dos homens e as mulheres querem falar as coisas de mulheres (Gilnei, 69 anos).

Parece que nossa cultura ainda impera a segregação social entre homens e mulheres, que estabelecem relações de discriminação e encontram dificuldades em se integrar. É possível que as diferenças para as quais nos remete a categoria sexo sejam mais importantes nas nossas relações do que as semelhanças da grande categoria ser humano.

Os estereótipos de gênero pregam que, quando há um homem e uma mulher que não fazem parte da mesma família e estão juntos, deve haver outro vínculo, além da amizade. Nesta pesquisa, os Grupos de Terceira Idade foram apontados também como um espaço para o encontro amoroso.

Alexandre (77 anos), José (73 anos), Paulo (68 anos) e Gilnei (69 anos) descreveram o Grupo de Terceira Idade como um lugar de mulheres, do qual alguns homens participam com a finalidade de conhecer uma companheira para casar, ou uma parceira sexual. Conforme Alexandre (77 anos): O fator ali é mais para agregar ou unir os viúvos, ele e ela, viúvos e tal (...) vão e se casam.

Logo, homens que não desejam ter algum envolvimento amoroso não participam destes grupos, sendo mais uma razão para a pouca participação masculina. Inclusive, os dois homens entrevistados casados e cujas esposas não participavam de Grupos de Terceira Idade, impuseram como condição para a sua participação que as suas esposas também o fizessem.

A aposentadoria apresentou-se como outro motivo para os homens pouco participarem dos grupos de terceira idade. Os homens retomam para seus aposentos. Inclusive a palavra aposentadoria, segundo Carlos, Jacques, Larratea e Heredia (1999), na língua portuguesa, etimologicamente, está relacionada à hospedagem, abrigo nos aposentos, sendo estes os quartos, o interior das casas. Portanto, a partir desta ideia, ao aposentado cabe ficar nos aposentos da casa, descansando. 
Esse foi o caso de Alexandre (77 anos), de Paulo (68 anos) e de Afonso (75 anos) que depois de se aposentarem passaram a ficar em casa. Alexandre comentou que não tem por que sair de casa, se está feliz assim. Já Paulo (68) e Afonso (75) tinham como atividade preferida assistir a esportes na televisão. Afonso (75) explicou que, após a aposentadoria e o avanço da idade, ficou muito parado: eu não fiz mais nada, só incomodo a mulher (...) sou muito caseiro agora.

A "casa", assim como a "rua", não se restringem ao espaço geográfico, constituindo-se

entidades morais, esferas de ação social, províncias éticas dotadas de positividade, domínios culturais institucionalizados e, por causa disto, capazes de despertar emoções, reações, leis, orações, música e imagens esteticamente emolduradas e inspiradas (DaMatta, 1991, p.17).

Com esta compreensão levanta-se a possibilidade de que, na aposentadoria, quando o homem ocupa a casa a mulher vai para os grupos de terceira idade, auxiliando este processo de maior participação feminina nestes grupos.

No que se refere à aposentadoria, destaca-se outro aspecto: sensação de falta de vitalidade ou disposição para participar de um grupo ou de atividades. Para Nolasco (1995), o trabalho, por um lado, é a base da identidade masculina, por outro, pode ser o responsável pelo esvaziamento e despersonalização dos homens quando este falta ou lhes é retirado, como no caso da aposentadoria. Paulo (68 anos) expôs a problemática de estar aposentado: é coisa dura, triste, no caso assim, se você não participa de nada, você fica assim, você fica amuado hoje, amuado amanhãa, se vai daqui para ali, dali para aqui, todo o dia, então vai se tornando uma coisa enjoativa (...) eu acho que a velhice é isso aí, tem hora que a gente não tem disposição de fazer nada.

Um dos entrevistados que frequentava um Centro de Convivência demonstrou que ele se apropriava aquele espaço como uma "casa". Buscou o grupo para ser cuidado pelas mulheres que lá coordenavam: a primeira pessoa me recebeu na porta, ela e outras duas daqui, também muito queridas... tudo isso é o que me trouxe aqui. Se a gente não recebe aquele agrado, (...) já não dá. Almir (60 anos). Esse entrevistado indica uma possível razão que explique por que alguns homens vão para o grupo: para encontrarem atenção, carinho, amizade e afeto.

Outro motivo que contribui para a pouca participação masculina é a continuidade de uma atividade de trabalho, mesmo após a aposentadoria. Milton (73 anos) explicitou que continuava trabalhando, pois é isso aí que me dá vida, motivação de viver, sentido da vida. Gilnei (69 anos) disse que, entre ir para o Grupo de Terceira Idade e continuar exercendo a sua atividade, prefere a última, porque a pessoa que está acostumada a trabalhar, chega em casa, gosta de quando retoma do dia de atividades, ter contato com outras pessoas, fez alguma coisa, conversou, esteve envolvido em tarefas, trocou ideias e isso faz bem pra pessoa, principalmente para o aposentado.

Como os grupos de terceira idade apresentam-se como uma possibilidade de convivência e atividade, quem já tem um cotidiano com estas características não participa destes grupos.

Uma característica implícita dos grupos de terceira idade é que este é dirigido para pessoas acima de sessenta anos, ou seja, para velhos/as. E necessário lembrar que quem é velho é o outro, pois o estereótipo formado sobre a velhice se configura de um tal modo que vivê-lo é quase impossível. A demonstração disto foi que a velhice foi descrita, pela maioria dos entrevistados, como morada da doença, da morte, da tristeza, da falta de disposição, entre outros qualificativos negativos. Logo, para participar de um grupo de terceira idade é preciso transpor o próprio preconceito de se autoqualificar como pertencente a "terceira idade".

Almir (60 anos) ao ser perguntado sobre por que a maioria dos homens não participava dos Grupos de Terceira Idade, foi categórico: pra não se misturar com a terceira idade (...) é que ele acha que ele não tá velho para se meter aqui. Preconceito. Milton (73) também se referiu ao preconceito como um motivo para as pessoas não participarem: às vezes até o preconceito contra a própria idade mesmo, (...) se ela se meter em Grupo de Terceira Idade, ela mesmo confessa que tá na terceira idade.

A idade não é um dado da natureza, nem um fator explicativo para os comportamentos humanos, portanto, a velhice não carrega em si mesma "propriedades substanciais que os indivíduos adquirem com o avanço da idade cronológica" (Debert, 1998, p.51). A velhice, neste momento histórico e na nossa cultura, está atrelada à idade cronológica, sendo uma 
normatização a partir do calendário gregoriano, portanto é uma arbitrariedade, da qual muitos tentam, mas não conseguem fugir. Participar de um grupo de terceira idade é colocar-se em um lugar social repleto de mitos e preconceitos.

O grupo de terceira idade foi relacionado ao período em que as pessoas passavam seu tempo estando na antessala da morte. Gilnei (69) explicitou essa situação: a impressão que me deixou é que todo mundo já viveu e agora é uma reunião pra ir lá e contar a última história. Quando este grupo é visto como um lugar sem vida e aonde se espera a morte, as pessoas que estão ávidas por viver não o frequentariam. No atual contexto social, econômico e de valores em que vivemos, parece óbvio que a maioria das pessoas não quer ser "velho/a", apesar de querer viver mais tempo.

Outro preconceito citado pelos entrevistados está relacionado ao estigma da pobreza: tem gente que não vem aqui porque não quer se misturar, porque acha que aqui é tudo pobre (...) eu achava que isso aqui era pra gente que não tinha comida, gente mais pobre, doente (Almir, 60 anos). A pergunta que ficou é: estas são questões relativas ao envelhecer ou às circunstâncias sociais em que o envelhecer posiciona o ser humano?

Finalizando, pode-se afirmar que outra razão para pouca participação dos homens (e talvez mulheres) nos grupos de terceira idade é não desejarem pertencer a um grupo com estes estereótipos. Ou seja, aqueles que se percebem independentes, saudáveis, com vitalidade, "jovens", ativos, sem precisar de cuidados, não veem o grupo como um espaço possível para estarem inseridos.

\section{Considerações finais}

Ao longo do percurso desta pesquisa, chegamos a várias possibilidades sobre por que há poucos homens nos Grupos de Terceira Idade e além disso, foi possível defini-lo. Os Grupos de Terceira Idade foram se delimitando como diferentes de outros grupos de pessoas com mais de sessenta anos. Pessoas desta idade, que se reúnem pelos mais variados motivos, não formam necessariamente um Grupo de Terceira Idade.

Grupos de Terceira Idade foram identificados como pertencendo e sendo indicados para as mulheres, sendo evidenciado preconceito de gênero e exclusão sexista. Atrelada a esta característica surgiu outra, os homens que se dirigem para estes espaços estariam procurando pelo estereótipo que o feminino representa: relacionamento amoroso ou cuidado. O Grupo de Terceira Idade ser caracterizado como um espaço feminino, isto, por si só, passa a ser um problema para a participação dos homens, pois os valores sociais são separatistas e segregadores.

Muitos homens sentem-se constrangidos e isolados quando se percebem "sozinhos", ou em pequeno número entre as mulheres. Acentua-se a palavra "sozinhos" porque recorrentemente, as pessoas costumam falar que homem está sozinho, quando ele está apenas entre mulheres. A referência é o gênero, se fosse as pessoas, como poderia estar sozinho? Se a pesquisa fosse com mulheres, talvez estes dados não se alterassem, pois há uma exclusão sexista em nossa sociedade. Esta é uma sugestão para futuras pesquisas.

O Grupo de Terceira Idade também foi significado como tendo uma vocação terapêutica. Para cumprir esta função, ocuparia o tempo das pessoas velhas com atividades relacionadas ao bem-estar físico e psicológico, educando-as para uma velhice saudável. Com isso estes grupos exercem dois papéis: o primeiro é que, na maior parte das vezes, seus participantes realmente obtém maior satisfação em suas vidas; o segundo é que retira a responsabilidade desse modelo socioeconômico que produz velhices doentes, incapazes para o trabalho, pobres, indesejáveis e sem desejos e remete, às pessoas individualmente, a responsabilidade pela sua saúde e bem-estar, desconsiderando que, ao longo de sua vida, estas mesmas pessoas foram valorizadas pela sua capacidade de produzir e trabalhar, não por cuidarem de seu bem-estar e sua saúde.

Muitos homens não participam dos Grupos de Terceira Idade porque se aposentam e continuam a trabalhar. Trabalho: palavra fundamental para estes homens, pois é ele quem os dignifica, mesmo na aposentadoria. Muitos preferem continuar exercendo atividades profissionais que não são encontradas no Grupo de Terceira Idade.

Outro fator de afastamento dos homens foi não se identificar com a "terceira idade" ou velhice, devido aos preconceitos e estereótipos vinculados a este termo. Parece que a velhice ganha visibilidade quando atrelada a um destes estereótipos. Será que a doença ou a falta de desejo de viver são inerentes aos anos que temos ou à velhice? 
Uma contribuição desta pesquisa foi esclarecer vários aspectos sobre a pouca participação dos homens nos grupos de terceira idade. Uma sugestão é investigar quais os fatores envolvidos quando mulheres não participam de grupos de terceira idade; outra é verificar como as mulheres que estão nos grupos avaliam os resultados apontados neste estudo.

Neste trabalho se aponta algumas determinações e estereótipos que perpetuam as exclusões de gênero. Destaca-se a linguagem sexista utilizada por muitos profissionais para dirigirem-se a estes grupos. Com este conhecimento, poderemos refletir sobre a necessidade de cuidado com a linguagem e práticas de exclusão que adotamos nos Grupos de Terceira Idade. É trilhando o caminho do diálogo, da interação e da conscientização das desigualdades poderemos contribuir para modificar a atual estrutura social separatista e excludente que temos atualmente.

Um caminho que tem sido perseguido é o do desejo de permanecermos jovens, saudáveis, ativos e produtivos. Será que esta é a única possibilidade de viver com reconhecimento, dignidade e integrado ao meio social? Enquanto for assim, a velhice continuará a ser um projeto praticamente irrealizável em nossa cultura.

Homens e mulheres podem compartilhar dos mesmos espaços, respeitando as diferenças que são características da singularidade humana e enriquecendo-se com as diversidades de experiências que só o ser humano pode abarcar. É inadmissível que em um mundo, onde se prega a racionalização e a lógica, tenhamos tantos preconceitos e estereótipos que segregam homens e mulheres a ponto de precisarem viver em mundos separados. O mesmo é válido para crianças, jovens, adultos/as e velhos/as. A integração e o compartilhar de nossas experiências, nossos sentimentos, nossos valores, daquilo que somos, só poderá trazer maior consciência da diversidade da experiência humana e aprendizado para aqueles/as que falam e aqueles/as que escutam. Neste compartilhar, homens e mulheres poderiam se encontrar e entender que seus mundos não são tão diferentes ou distantes. A experiência de ser humano/a nos torna muito mais iguais nas diferenças, existindo a possibilidade de vislumbrar outros modos de relacionamento entre as pessoas e com o mundo.
Referências

Bardin, L. (1991). Análise de Conteúdo. Lisboa: Edições 70.

Carlos, S. A., Jacques, M. da G. c., Larratea, S. V. \& Heredia, O. C. (1999). Identidade, aposentadoria e terceira idade. Cadernos de Envelhecimento, 1 (1), p.77-88.

DaMatta, R. (1991). A casa e a rua: espaço, cidadania, mulher e morte no Brasil. $4^{\mathrm{a}}$ ed. Rio de Janeiro: Guanabara Koogan S.A.

Debert, G. G. (1994). Gênero e envelhecimento. Estudos Feministas 2 (1), p.33-51.

(1998). "A antropologia e o estudo dos grupos e das categorias de idade”. In: M. M. L. de Barros (org.), Velhice ou terceira idade? Estudos antropológicos sobre identidade, memória e política (p.4968). Rio de Janeiro: Editora Fundação Getúlio Vargas.

(1999) A Reinvenção da Velhice: socialização e processos de reprivatização do envelhecimento. São Paulo: Editora da Universidade de São Paulo: Fapesp.

Ferrigno, J. C. (1998). "Grupos de reflexão sobre o envelhecimento: uma proposta de reconstrução da autonomia de homens e mulheres na $3^{\text {a }}$ Idade”. Gerontologia, 6 (1) p.27-33.

Gomes, W. B. (1997). “A entrevista fenomenológica e o estudo da experiência consciente”. Psicologia USP, 8 (2), p.305-336.

Kude, V. M. M (1999). "O método fenomenológico na pesquisa em ciências humanas”. Educação (37), p.51-72.

Laville, C. e Dionne, J. (1999) A construção do saber: manual de metodologia da pesquisa em ciências sociais. Porto Alegre: Artemed.

Minayo, M. C. de S. (1999). O desafio do conhecimento: pesquisa qualitativa em saúde. ( $6^{\mathrm{a}}$ ed). São Paulo/Rio de Janeiro: HUCITECABRASCO.

Moraes, R. (1993). Análise de conteúdo. Porto Alegre: Curso de PósGraduação em Educação/ PUCRS (mimeo).

Moraes, R. (1999). Análise de conteúdo. Educação (37), p.7-32. 
Navarro, P. \& Díaz, C. (1994). “Análisis de contenido”. In: J. M. Delgado \& J. Gutiérrez. (orgs.), Métodos y técnicas cualitativas de investigación en ciencias sociales (p.177-221). Madrid: Síntesis S.A.

Neri, A. L. \& Cachioni, M. (1999). "Velhice bem-sucedida e educação". In: A. L. Neri \& G. G. Debert (orgs.). Velhice e sociedade (p.113-140). Campinas, São Paulo: Papirus.

Nolasco, S. (1995). O mito da masculinidade. ( $2^{\mathrm{a}}$ ed). Rio de Janeiro: Rocco.

Peixoto, C. (1997). "De volta às aulas ou de como ser estudante aos 60 anos". In: R. Veras (org.) Terceira Idade: desafios para o terceiro milênio (p.75-102). Rio de Janeiro: Relume-Dumará.

(1998). "Entre o estigma e a compaixão e os termos classificatórios: velho, velhote, idoso, terceira idade". In: M. M. L. de Barros (org.) Velhice ou terceira idade? Estudos antropológicos sobre identidade, memória e política (p.69-84). Rio de Janeiro: Editora Fundação Getúlio Vargas.

Richardson, R. J. (1989). Pesquisa social: métodos e técnicas. $2^{\mathrm{a}}$ ed. São Paulo: Atlas S.A.

Sais, A. P. (1995). Coisas de velho: coisas de vida. Dissertação de Mestrado. São Paulo: PUCSP.

Sant'Anna, M. J. G. (1997). "UnATI, a velhice que se aprende na escola: um perfil de seus usuários". In: R. Veras (org.) Terceira Idade: desafios para o terceiro milênio (pp.75-102). Rio de Janeiro: Relume-Dumará.

Simões, R. (1994). Corporeidade e terceira idade. Piracicaba: UNIMEP.

Strey, M. N. (1998). "Gênero". In: M. da G. Jacques, M. N. Strey, N. M. G. Bernardes, P. A. Guareschi, S. A. Carlos \& T. M. Fonseca (orgs.). Psicologia social contemporânea: livro texto (p.181-198). Petrópolis, Rio de Janeiro: Vozes.

Trivinos, A. N. S. (1987). Introdução a pesquisa em ciências sociais: a pesquisa qualitativa em educação. São Paulo: Atlas.
Veras, R. \& Camargo Jr., K. R. (1995). "Idosos e universidade: parceria para qualidade de vida". In: R. Veras et al. (orgs.) Terceira Idade: um envelhecimento digno para o cidadão do futuro (p.11-28). Rio de Janeiro: Relume-Dumará: UnATI/UERJ. 